\title{
REMOÇÃO DE NITROGÊNIO DE ÁGUAS RESIDUÁRIAS COM ELEVADA CONCENTRAÇÃO DE NITROGÊNIO AMONIACAL EM REATOR CONTENDO BIOMASSA EM SUSPENSÃO OPERADO EM BATELADAS SEQÜENCIAIS E SOB AERAÇÃO INTERMITENTE
}

\begin{abstract}
Tese apresentada à Escola de Engenharia de São Carlos da Universidade de São Paulo, como parte dos requisitos para a obtenção do Título de Doutor em Hidráulica e Saneamento.
\end{abstract}

Orientador: Prof. Titular Dr. Eugenio Foresti

São Carlos 
Ficha catalográfica preparada pela Seção de Tratamento da Informação do Serviço de Biblioteca - EESC/USP

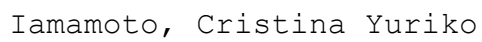

I11r Remoção de nitrogênio de águas residuárias com elevada concentração de nitrogênio amoniacal em reator contendo biomassa em suspensão operado em bateladas seqüenciais e sob aeração intermitente / Cristina Yuriko Iamamoto. -- São Carlos, 2006.

Tese(Doutorado) -- Escola de Engenharia de São Carlos-Universidade de São Paulo, 2006.

Área: Hidráulica e Saneamento.

Orientador: Prof. Titular Dr. Eugenio Foresti 
FOLHA DE JULGAMENTO

Candidata: Engenheira CRISTINA YURIKO IAMAMOTO

Tese defendida e julgada em 04-08-2006 perante a Comissão Julgadora:

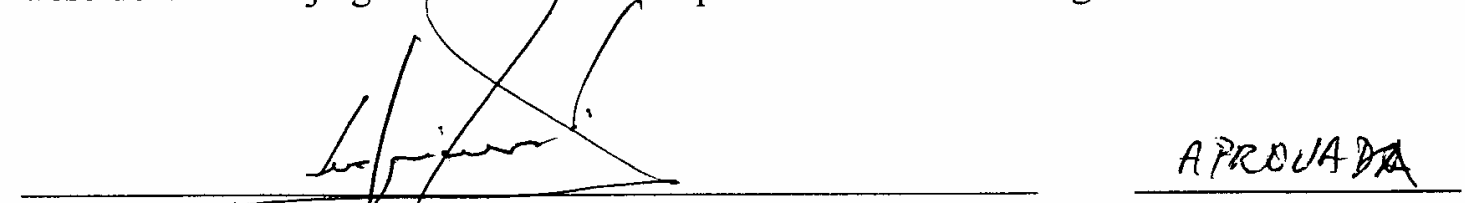

Prof. Titular EUGENI $\phi$ FORESTI (Orientador)

(Escola de Engenharja de São Carlos/USP)

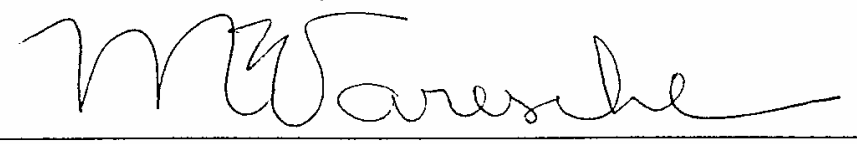

\section{Prof $^{\mathrm{a}}$. Dr ${ }^{\mathrm{a}}$. MARIA BERNADETE AMANCIO VARESCHE SILVA}

(Escola de Engenharia de São Carlos/USP)

Golion Silva

Prof. Dr. EDSON LUIZ SILVA

(Universidade Federal de São Carlos/UFSCar)

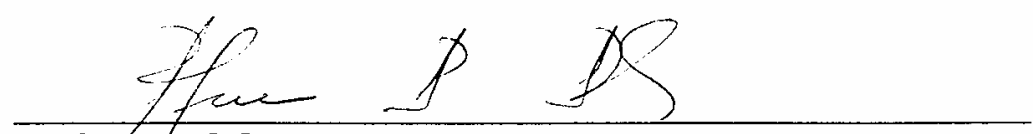

Prof Dr/ROQUE PASSOS PIVELI

(Escola Politécnica/USP)

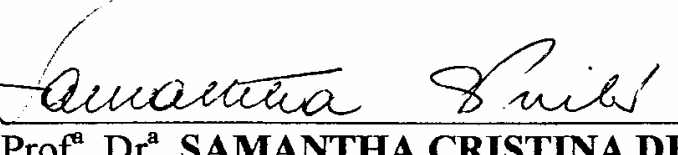

Prof $^{\mathrm{a}}$. Dr ${ }^{\mathrm{a}}$. SAMANTHA CRISTINA DE PINHO

(Faculdade de Zootecnia e Engenharia de Alimentos/USP)

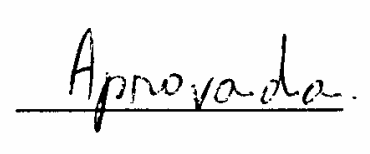

$A$ Dथख?
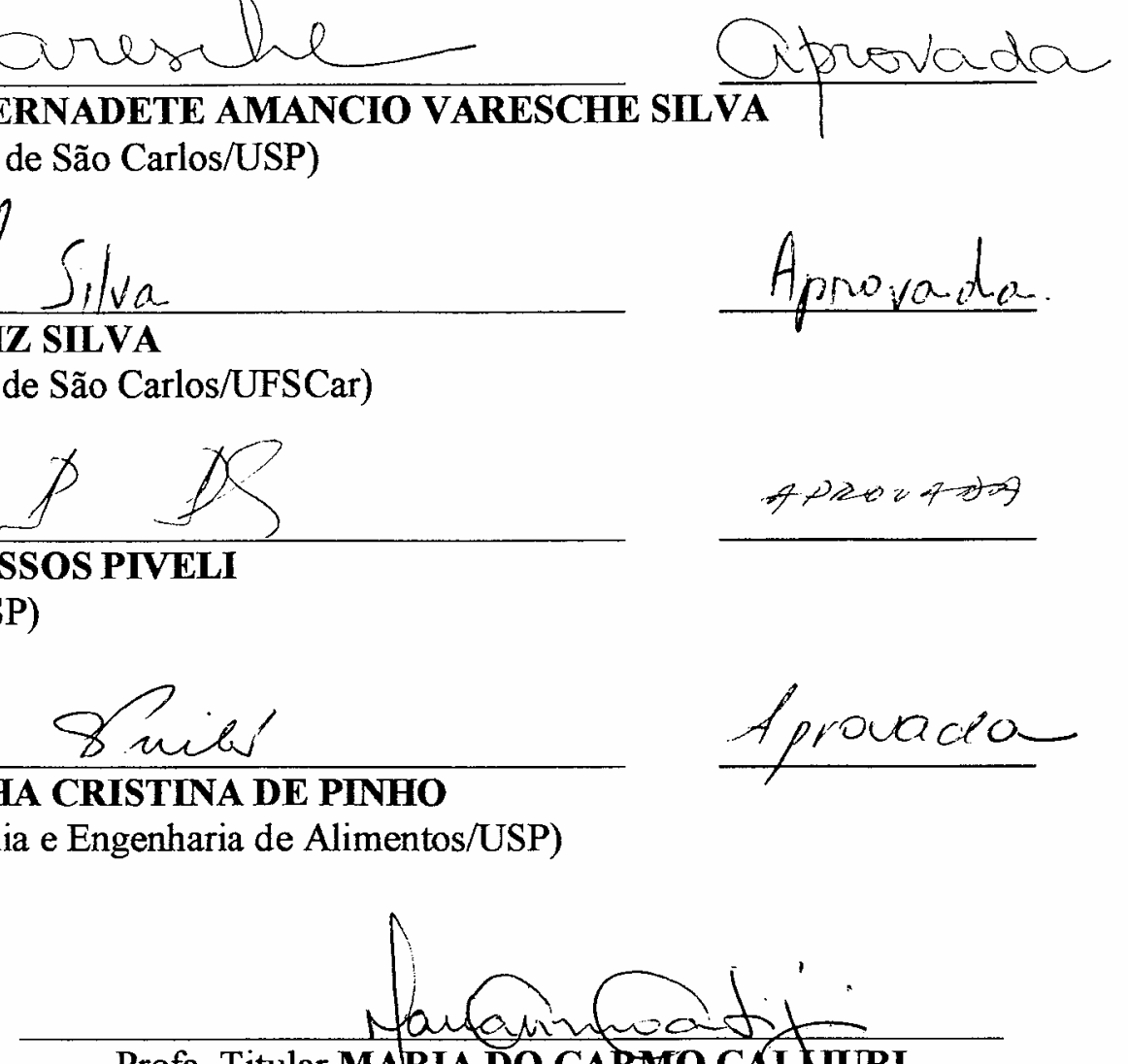

Profa. Titular MARIA DO CARMO CALFURI

Coordenadora do Programa de Pós-Graduaçăo em

Engenharia (Hidráulica e Saneamento) e

Presidente da Comissão de Pós-Graduação 


\section{Dedico}

Este trabalho dedico a meus queridos pais Take mito e $\mathrm{M}$ a s a ko (in memorian) e a me us irmãos Marcos, Marina e Y u k i o . 


\section{AGRADECIMENTOS}

Ao prof. Eugenio Foresti pela oportunidade de desenvolver este trabalho e apoio durante todo o doutorado.

Aos meus queridos pais, por todo o amor, por todo o exemplo de dedicação e perseverança. Aos seus sonhos, minha mãe querida.

Aos meus irmãos, Marcos, Marina e Yukio.

À minha amiga Francislene Fenerich, por sua amizade e maturidade .

À minha amiga Leonidia Maria de Castro Daniel, por sua presença amiga, seus conselhos tanto científicos quanto pessoais.

Aos amigos da graduação: Elizabeth Y. Takaki, Leni E. Ito, Patricia M. C. Sarkis e Daniel R. T. Ferreira.

Aos amigos que adquiri durante o mestrado: Sandra R.O. Queiroz, Gisele Bonacin, Luciana Ynone, Rosana Ferreira, Márcia Mataqueiro e Serguey A. Camargo.

Aos amigos que adquiri durante o doutorado: Luana M. Marelli, Isabel K. Sakamoto, Mércia R. Domingues, Dirlane Carmo, Marisi S. Gomes, José Alberto Correia Leite, Neyson Mendonça, Arnaldo Sarti, Clésia C. Nascentes, Júlia S. Hirasawa, Andréa Buzzini, Kátia N. Saavedra, Bruna S. Fernandes, Daniele V. Vich e Eveline Duarte.

À Eloísa Pozzi, Fabio A. Chinaglia, Ana Lúcia G. Spínola e Daniele V. Vich pelos exames microbiológicos.

Aos técnicos Vagner Lamon, Roberto Bérgamo, Paulo Frangiacomo e Júlio Troffino.

Às técnicas Ana Paula S. Paim, Maria Ângela Adorno Talarico, Elizabeth M. Moraes, Glauce G. Pereira.

Às secretárias Rose Jesus, Sá e Pavi.

À coordenação do LPB e LATAR, departamento de Hidráulica e Saneamento e PCASC, pela infra-estrutura cedida para o experimento.

À todas as pessoas que conheci e que colaboraram para que concluísse mais essa fase. 


\section{RESUMO}

IAMAMOTO, C.Y. (2006). Remoção de nitrogênio de águas residuárias com elevada concentração de nitrogênio amoniacal em reator contendo biomassa em suspensão operado em bateladas seqüenciais e sob aeração intermitente. Tese (doutorado) Escola de Engenharia de São Paulo, São Carlos, 2006.

$\mathrm{O}$ reator em batelada seqüencial com biomassa em suspensão foi submetido a concentrações de N-amoniacal de 125, 250 e $500 \mathrm{mg}$ N/L e em condições de oxigênio

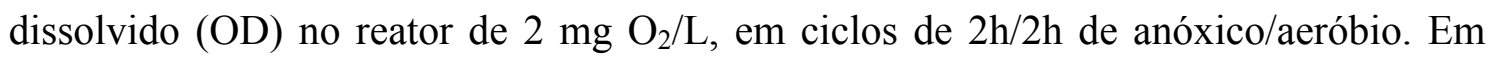
todas as fases, o reator foi operado como batelada alimentada. Na condição de $125 \mathrm{mg}$ N/L obteve-se eficiência de remoção de $87 \%$ de $\mathrm{N}$, tendo o nitrato sido o principal produto da nitrificação. Na condição de $250 \mathrm{mg} \mathrm{N} / \mathrm{L}$, obteve-se eficiência de remoção de $\mathrm{N}$ de $84 \%$, com predominância de nitrito como principal produto da nitrificação e com ocorrência de nitrificação e desnitrificação simultânea durante os dois primeiros ciclos aeróbios. Na condição de $500 \mathrm{mg} \mathrm{N} / \mathrm{L}$, as condições de concentração de OD de 2 mg $\mathrm{O}_{2} / \mathrm{L}$ e aeração intermitente a cada $2 \mathrm{~h}$ não foram suficientes para promover a remoção total de nitrogênio amoniacal. Foram feitas alterações: ciclos de $2 \mathrm{~h}$ anóxico e 9h aeróbios, com concentração média de $2,8 \mathrm{mg} \mathrm{\textrm {O } _ { 2 }} / \mathrm{L}$, que resultaram em eficiências de remoção de $\mathrm{N}$ de 94\%, com predominância de nitrito. Foram isoladas cepas desnitrificantes com similaridade de 97\% para Thauera mechernichensis e Thauera sp. 27 nas condições operacionais de 125 e $250 \mathrm{mgN} / \mathrm{L}$ e de $99 \%$ para Ochrobactrum anthropi e Ochrobactrum tritici, na condição operacional de $500 \mathrm{mgN} / \mathrm{L}$.O longo tempo de operação resultou na diminuição da população de bactérias oxidantes de nitrito, podendo ter sido uma das causas que contribuiu para que se criassem condições que levariam à nitrificação via nitrito na concentração de $500 \mathrm{mg} \mathrm{N} / \mathrm{L}$. O sucesso na prevenção da inibição do processo por amônia livre foi atribuído à adoção das condições operacionais do reator, que foi operado sob aeração intermitente e batelada alimentada.

Palavras- chave: nitrificação, desnitrificação, aeração intermitente, reator aeróbio em batelada seqüencial, batelada alimentada. 


\section{ABSTRACT}

IAMAMOTO, C.Y. (2006). Nitrogen removal of wastewaters with high ammonium nitrogen concentrations in reactor containing suspended biomass operated in sequential batch and under intermittent aeration. $\mathrm{PhD}$. thesis - Escola de Engenharia de São Paulo, São Carlos, 2006.

The sequential batch reactor with suspended bioma was subjected to ammonium concentrations of 125,250 and $500 \mathrm{mg} \mathrm{N} / \mathrm{L}$, oxygen dissolved (OD) concentrations of 2 $\mathrm{mg} \mathrm{O}_{2} / \mathrm{L}, 2 \mathrm{~h} / 2 \mathrm{~h}$ of anoxic/aerobic steps. The reactor was operated under fed-batch feeding. At the operational condition of $125 \mathrm{mg} \mathrm{N} / \mathrm{L}$, the mean nitrogen removal efficiency of $87 \%$ was obtained and nitrate was the main nitrification product. At operational condition of $250 \mathrm{mg} \mathrm{N} / \mathrm{L}$, was gotten nitrogen removal efficiencies of $84 \%$ and nitrite was the predominant form of nitrogen and simultaneous nitrification and denitrification occurred during the two first aerobic steps of the cycle. At $500 \mathrm{mg} \mathrm{N} / \mathrm{L}$, the operating conditions imposed to the reactor (OD concentrations of $2 \mathrm{mg} \mathrm{O} / \mathrm{L}$ and intermittent aeration of $2 \mathrm{~h}$ ) did not lead to complete nitrification during the aerated steps, thus affecting nitrogen removal. The conditions were altered increasing the aerated steps to 9 hours, with OD concentration of $2,8 \mathrm{mg} \mathrm{O}_{2} / \mathrm{L}$, and keeping the duration of the anoxic steps in 2 hours. Under such conditions, the mean nitrogen removal efficiency attained $94 \%$ and nitrite was the predominant oxidized nitrogen specie. It was isolated denitrifiers with similarity of $97 \%$ for Thauera mechernichensis and Thauera sp. 27 at the operational conditions of 125 and $250 \mathrm{mgN} / \mathrm{L}$ and of $99 \%$ for Ochrobactrum anthropi and Ochrobactrum tritici, at operational condition of 500 $\mathrm{mgN} / \mathrm{L}$. The long term operation resulted in the decrease of nitrite oxidizers populations and this was probably the main factor contributing for the creation of conditions for the partial nitrification via nitrite to prevail during the operation at ammonium concentration of $500 \mathrm{mg} \mathrm{N} / \mathrm{L}$. The success in preventing free ammonia inhibition was attributed to the adoption of intermittent aeration and fed batch operation.

Keywords: nitrification, denitrification, intermittent aeration, fed-batch, sequential batch reactor 


\section{LISTA DE FIGURAS}

Figura 3.1 - Gráfico de tolerância à amônia livre para ocorrência de nitrificação._Fonte ANTHONISEN et al. (1976); ÇEÇEN (1996).

Figura 3.2 - Breakpoints no perfil de potencial redox. Fonte: WAREHAM et al. (1993) ........ 33

Figura 4.1 - Reator aeróbio em batelada seqüencial

Figura 4.2 - Esquema do sistema: (1) recipiente com substrato mantido refrigerado; (2) bomba de entrada do afluente; (3) compressor de ar; (4) computador; (5) bloco de aquisição de dados; (6) agitador; (7) pedra porosa; (8) reator de acrílico de 6,5 L; medidor de OD; (10) bomba de saída.

Figura 4.3 - Estratégia operacional do reator aeróbio em batelada seqüencial. Cinco períodos anóxicos/ aeróbios. $\mathrm{AN}=$ anóxico; $\mathrm{AER}=$ aeróbio

Figura 4.4 - Fluxograma da seqüência dos exames microbiológicos.

Figura 5.1 - Eficiências de remoção de nitrogênio durante a condição operacional de $125 \mathrm{mg}$ $\mathrm{N} / \mathrm{L}$ e sob duas condições de concentração de OD

Figura 5.2 - Microfotografias do lodo no final da condição operacional de125 mg N/L e concentração de OD de $2 \mathrm{mg} \mathrm{O} / \mathrm{L}$ : (a) cocos; (b) arranjo de cocos; (c) filamentosas -semelhante a Microthrix parvicella; (d) filamento semelhante ao tipo 021N.... 56

Figura 5.3 - Microfotografias do lodo no final da condição operacional de $125 \mathrm{mg} \mathrm{N} / \mathrm{L}$ e concentração de OD de 1,5 $\mathrm{mg} \mathrm{O}_{2} / \mathrm{L}$ : (a) bactérias filamentosas; (b) sarcinas; (c) bactérias filamentosas; (d) bactéria semelhante a Nostocoida limicola.

Figura 5.4 - Variação temporal das concentrações de $\mathrm{N}$-amoniacal durante condição operacional de $125 \mathrm{mg} \mathrm{N} / \mathrm{L}$ em concentração média de OD de $2 \mathrm{mg} \mathrm{O}_{2} / \mathrm{L}$ aos 84 dias de experimento.

Figura 5.5 - Variação temporal das concentrações de nitrato durante condição operacional de $125 \mathrm{mg}$ N/L em concentração média de OD de 2 mg O $2 / \mathrm{L}$ : (a) aos 84dias; (b) aos 180 dias de experimento.

Figura 5.6 - Variação temporal das concentrações de nitrato durante condição operacional de $125 \mathrm{mg} \mathrm{N} / \mathrm{L}$ em concentração média de OD de 1,5 mg O $2 / \mathrm{L}$ aos 156 dias de experimento.

Figura 5.7 - Variação temporal dos valores de pH durante a condição operacional de $125 \mathrm{mg}$ $\mathrm{N} / \mathrm{L}$ : (a) aos 84dias em concentração de OD de $2 \mathrm{mg} \mathrm{O} / \mathrm{L}$; (b) aos 156 dias em concentração de OD de 1,5 mg $\mathrm{O}_{2} / \mathrm{L}$; (c) aos 180 dias em concentração de OD de $2 \mathrm{mg} \mathrm{O}_{2} / \mathrm{L}$.

Figura 5.8 - Variação temporal das concentrações de amônia livre durante a condição operacional de $125 \mathrm{mg} \mathrm{N} / \mathrm{L}$ : (a) aos 84 dias em concentração de OD de $2 \mathrm{mg} \mathrm{O} / \mathrm{L}$; (b) aos 156 dias em concentração de OD de $1,5 \mathrm{mg} \mathrm{O} / \mathrm{L} \mathrm{e} \mathrm{(c)} \mathrm{aos} 180$ dias em concentração de OD de $2 \mathrm{mg} \mathrm{O} / \mathrm{L}$

Figura 5.9 - Variação do pH afluente e efluente durante condição operacional de $125 \mathrm{mg} \mathrm{N} / \mathrm{L}$ e sob duas condições de OD.

Figura 5.10 - Variação da alcalinidade a bicarbonato (AB) afluente e efluente durante a 
Figura 5.11 - Variação temporal dos valores de potencial redox e concentrações de OD durante

a condição operacional de $125 \mathrm{mg} \mathrm{N} / \mathrm{L}$ aos 84 dias.

Figura 5.12 - Variação temporal dos valores de potencial redox e concentrações de OD durante

a condição operacional de $125 \mathrm{mg} \mathrm{N} / \mathrm{L}$ aos 180 dias.

Figura 5.13 - Variação temporal dos parâmetros durante um ciclo anóxico/ aeróbio de $4 \mathrm{~h}$ durante a condição operacional de $125 \mathrm{mg} \mathrm{N} / \mathrm{L}$ em concentração média de OD de $2 \mathrm{mg} \mathrm{O}_{2} / \mathrm{L}$ aos $71 \mathrm{~d}$ de experimento: (a) potencial redox com concentrações de OD; (b) potencial redox com concentrações de nitrato; (c) variação do potencial redox com o tempo (dPOR/dt).

Figura 5.14 - Variação temporal dos parâmetros durante um ciclo anóxico/aeróbio de 4h durante a condição operacional de $125 \mathrm{mg} \mathrm{N} / \mathrm{L}$ em concentração média de OD de $1,5 \mathrm{mg} \mathrm{O}_{2} / \mathrm{L}$ : (a) potencial redox com concentrações de OD; (b) potencial redox com concentrações de nitrato; (c) variação do potencial redox com o tempo $(\mathrm{dPOR} / \mathrm{dt})$

Figura 5.15 - Produção acumulada de $\mathrm{N}_{2} \mathrm{O}$ ao longo do tempo nos reatores 73

Figura 5.16 - Eficiência de remoção de nitrogênio e variação das concentrações de N-amoniacal efluente durante a condição operacional de $250 \mathrm{mg} \mathrm{N} / \mathrm{L}$

Figura 5.17 - Microfotografias microscopia ótica ao final da condição operacional de $250 \mathrm{mg}$ $\mathrm{N} / \mathrm{L}$, com concentração de OD de $2 \mathrm{mg} \mathrm{O}_{2} / \mathrm{L}$ : (a) bacilos com inclusões; (b) bactérias filamentosas; (c) bacilos diversos; (d) arranjo de cocos

Figura 5.18 - Variação temporal dos parâmetros durante a condição operacional de $250 \mathrm{mg}$

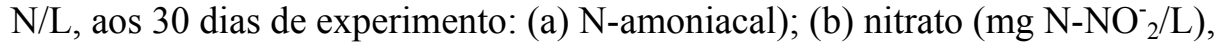

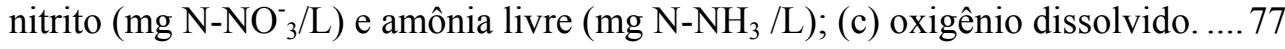

Figura 5.19 - Variação temporal dos parâmetros durante a condição operacional de $250 \mathrm{mg}$

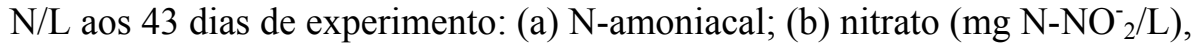

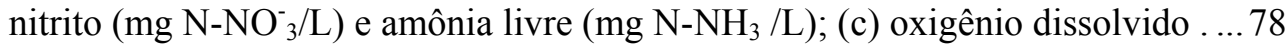

Figura 5.20 - Verificação da NDS durante a condição operacional de $250 \mathrm{mg}$ N/L: (a) aos 30 dias e (b) aos 43 dias de experimento.

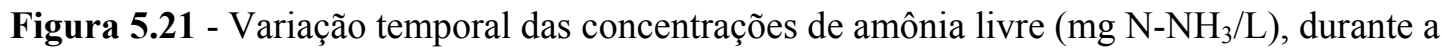
condição operacional de $250 \mathrm{mg} \mathrm{N} / \mathrm{L}$ : (a) aos 30 dias; (b) aos 43 dias de experimento.

Figura 5.22 - Variação dos valores de pH afluente e efluente durante a condição operacional de $250 \mathrm{mg} \mathrm{N} / \mathrm{L}$.

Figura 5.23 - Variação temporal dos valores de pH durante a condição operacional de $250 \mathrm{mg}$ N/L: (a) aos 30 dias e (b) aos 43 dias de experimento.

Figura 5.24 - Variação das concentrações de alcalinidade a bicarbonato (AB) afluente e efluente durante a condição operacional de $250 \mathrm{mg} \mathrm{N} / \mathrm{L}$

Figura 5.25 - Variação temporal dos valores de potencial redox e das concentrações de OD durante a condição operacional de $250 \mathrm{mg} \mathrm{N} / \mathrm{L}$ aos 30 dias.

Figura 5.26 - Variação temporal dos valores de potencial redox e das concentrações de OD durante a condição operacional de $250 \mathrm{mg} \mathrm{N} / \mathrm{L}$ aos 43 dias. 
Figura 5.27 - Variação temporal dos parâmetros durante um ciclo anóxico/ aeróbio de $4 \mathrm{~h}$ durante a condição operacional de $250 \mathrm{mg} \mathrm{N} / \mathrm{L}$ em concentração média de OD de 2 $\mathrm{mg} \mathrm{O}_{2} / \mathrm{L}$ : (a) potencial redox com concentrações de nitrato e nitrito; (b) potencial redox com concentrações de $\mathrm{N}$-amoniacal; (c) potencial redox com concentrações de OD; (d) variação do potencial redox com o tempo (dPOR/dt).

Figura 5.28 - Eficiências de remoção de nitrogênio durante a condição operacional de $500 \mathrm{mg}$ $\mathrm{N} / \mathrm{L}$, ciclos anóxicos/aeróbios de $2 \mathrm{~h} / 2 \mathrm{~h}$, sob duas condições de concentração de oxigênio dissolvido: (a) OD média de 2,9 $\mathrm{mg} \mathrm{O}_{2} / \mathrm{L} \mathrm{em} \mathrm{pH}$ afluente de 7,9; (b) OD média de 2,7 $\mathrm{mg} \mathrm{O}_{2} / \mathrm{L} \mathrm{em} \mathrm{pH}$ afluente de 7,7.

Figura 5.29 - Eficiências de remoção de nitrogênio durante a condição operacional de $500 \mathrm{mg}$ $\mathrm{N} / \mathrm{L}$, ciclos anóxicos/aeróbios de $2 \mathrm{~h} / 4 \mathrm{~h}$, sob duas condições de concentração de oxigênio dissolvido: (a) OD média de 3,2 $\mathrm{mg} \mathrm{O}_{2} / \mathrm{L} \mathrm{em} \mathrm{pH}$ afluente de 7,6; (b) OD média de 4,3 $\mathrm{mg} \mathrm{O}_{2} / \mathrm{L} \mathrm{em} \mathrm{pH}$ afluente de 7,7.

Figura 5.30 - Concentrações resultantes das formas de nitrogênio no efluente durante a condição operacional de $500 \mathrm{mg} \mathrm{N} / \mathrm{L}$ sob concentração média de OD de 2,8 mg $\mathrm{O}_{2} / \mathrm{L}$,em pH afluente de 8 e sob 2 ciclos anóxicos/aeróbios de $2 \mathrm{~h} / 9 \mathrm{~h}$.

Figura 5.31 - Eficiências de remoção de nitrogênio durante a condição operacional de $500 \mathrm{mg}$ N/L sob concentração média de OD de $2,8 \mathrm{mg} \mathrm{O} 2 / \mathrm{L}$,em pH afluente de 8 e sob 2 ciclos anóxicos/aeróbios de $2 \mathrm{~h} / 9 \mathrm{~h}$.

Figura 5.32 - Microfotografias do final da condição operacional de $500 \mathrm{mg} \mathrm{N} / \mathrm{L}$, com concentração média de OD média de $2,8 \mathrm{mg} \mathrm{O}_{2} / \mathrm{L}$. (a) ciliados pedunculados; (b) cistos de protozoários; (c) cocos e bacilos; (d) bacilos e filamentos; (e) e (f) bactérias acumuladoras de fósforo (coloração de Neisser).

Figura 5.33 - Variação temporal das concentrações de nitrito e N-amoniacal durante a condição operacional de $500 \mathrm{mg} \mathrm{N} / \mathrm{L}$ sob concentração de OD de $2,8 \mathrm{mg} \mathrm{O} / \mathrm{L}$,em pH afluente de 8 e sob 2 ciclos anóxicos/aeróbios de 2h/9h: (a) aos 43 dias; (b) aos 71 dias de experimento.

Figura 5.34. Concentrações das formas de nitrogênio durante os períodos aeróbios durante a condição operacional de $500 \mathrm{mg} \mathrm{N} / \mathrm{L}$ : (a) aos 43 dias e (b) aos 71 dias de experimento.

Figura 5.35 - Variação temporal das concentrações de nitrato e de amônia livre durante condição operacional de $500 \mathrm{mg} \mathrm{N} / \mathrm{L}$ sob concentração de $\mathrm{OD}$ de $2,8 \mathrm{mg} \mathrm{O} / \mathrm{L}$,em pH afluente de 8 e sob 2 ciclos anóxicos/aeróbios de 2h/9h: (a) aos 43dias; (b) aos 71 dias de experimento.

Figura 5.36 - Variação dos valores de pH durante a condição operacional de $500 \mathrm{mg} \mathrm{N} / \mathrm{L}$, ciclos anóxicos/aeróbios de $2 \mathrm{~h} / 2 \mathrm{~h}$ sob duas condições de concentração de oxigênio dissolvido:( a) OD média de 2,9 $\mathrm{mg} \mathrm{O}_{2} / \mathrm{L}$ e $\mathrm{pH}$ afluente de 7,9 e (b) OD média de $2,7 \mathrm{mg} \mathrm{O}_{2} / \mathrm{L} \mathrm{e} \mathrm{pH}$ afluente de 7,7.

Figura 5.37 - Variação dos valores de pH durante a condição operacional de $500 \mathrm{mg} \mathrm{N} / \mathrm{L}$, ciclos anóxicos/aeróbios de $2 \mathrm{~h} / 4 \mathrm{~h}$, sob duas condições de concentração de oxigênio dissolvido: (a) OD média de 3,2 $\mathrm{mg} \mathrm{O}_{2} / \mathrm{L}$ e $\mathrm{pH}$ afluente de 7,6 e (b) OD média de $4,3 \mathrm{mg} \mathrm{O}_{2} / \mathrm{L}$ e $\mathrm{pH}$ afluente de 7,7 .

Figura 5.38 - Variação dos valores de pH durante a condição operacional de $500 \mathrm{mg} \mathrm{N} / \mathrm{L}$ sob concentração média de OD de $2,8 \mathrm{mg} \mathrm{O}_{2} / \mathrm{L}$,em $\mathrm{pH}$ afluente de 8 e sob dois ciclos anóxicos/aeróbios de $2 \mathrm{~h} / 9 \mathrm{~h}$. 
Figura 5.39 - Variação temporal dos valores de potencial redox e das concentrações de OD durante condição operacional de $500 \mathrm{mg} \mathrm{N} / \mathrm{L}$ aos 43 dias.

Figura 5.40 - Variação temporal dos valores de potencial redox e das concentrações de OD durante a condição operacional de $500 \mathrm{mg} \mathrm{N} / \mathrm{L}$ aos 71 dias.

Figura 5.41 - Variação temporal dos parâmetros durante um ciclo anóxico/ aeróbio de $11 \mathrm{~h}$ durante a condição operacional de $500 \mathrm{mg} \mathrm{N} / \mathrm{L}$ em concentração média de OD de 2,8 $\mathrm{mg} \mathrm{O}_{2} / \mathrm{L}$ : (a) potencial redox com concentrações de nitrato; (b) potencial com concentrações de nitrito e $\mathrm{N}$-amoniacal; (d) potencial redox com concentrações de OD.

Figura 5.42. Variação dPOR/dt durante um ciclo anóxico/ aeróbio de $11 \mathrm{~h}$ durante a condição operacional de $500 \mathrm{mg} \mathrm{N} / \mathrm{L}$ em concentração média de OD de 2,8 mg $\mathrm{O}_{2} / \mathrm{L}$....... 101

Figura 5.43 - Variação das concentrações de fósforo afluente e efluente durante o experimento.

Figura 5.44 - Quantidade de elementos químicos (\%) encontrados nas microanálises quantitativas nas condições operacionais estudadas.

Figura 5.45 - Concentração de fósforo $(\mathrm{mg} \mathrm{P} / \mathrm{L})$ ao final das condições operacionais, levando em consideração os resultados das microanálises.

Figura 5.46 - Efeito da adição de etanol na variação temporal das concentrações de Namoniacal, nitrito, nitrato e etanol durante um período anóxico de $2 \mathrm{~h}$. Réplica 1._(a) consumo de etanol e (b) consumo de nitrito e nitrato.

Figura 5.47 - Efeito da adição de etanol na variação temporal das concentrações de Namoniacal, nitrito, nitrato e etanol durante um período anóxico de $2 \mathrm{~h}$. Réplica 2.(a) consumo de etanol e (b) consumo de nitrito e nitrato. 106

Figura 5.48 - Log da razão NMP das células e concentração de SSV nas condições operacionais descritas na Tabela 5.10 .

Figura 5.49 - Microfotografias da cepa isolada nas condições operacionais de 125 e $250 \mathrm{mg} \mathrm{N}$ /L: (a) cepa isolada, em contraste de fase; (b) bactérias Gram negativas; (c) coloração de Neisser (positivo); coloração de PHA (positivo).

Figura 5.50 - Microfotografias da cepa isolada na condição operacional de $500 \mathrm{mg}$ N/L: (a) cepa isolada, em contraste de fase; (b) bactérias Gram negativas; (c) coloração de Neisser (negativo); coloração de Neisser (negativo). 


\section{LISTA DE TABELAS}

Tabela 4.1 - Composição da solução de sais. 41

Tabela 4.2 - Composição da solução de micronutrientes.

Tabela 4.3 - Quantidades adicionadas dos principais componentes para composição do substrato em cada condição operacional de $\mathrm{N}$-amoniacal afluente. 42

Tabela 4.4. Caracterização do substrato em termos de $\mathrm{DQO}, \mathrm{pH}, \mathrm{NH}_{4}^{+}$e alcalinidade. 42

Tabela 4.5 - Descrição das condições das fases de operação - batelada de $24 \mathrm{~h}$ 44

Tabela 4.6 - Composição do substrato para ensaio de desnitrificação em condição operacional de N-amoniacal no afluente de $125 \mathrm{mg} / \mathrm{L} \mathrm{N}$.

Tabela 4.6 - Sais minerais e elementos-traço para crescimento de organismos nitrificantes.

Tabela 5.1 - Eficiências médias de remoção de nitrogênio (considerando as três formas: amoniacal, nitrato e nitrito) e porcentagem de nitrato no efluente em relação ao total de formas oxidadas $\left(\mathrm{NO}_{3}^{-} / \mathrm{N}^{-}\right.$ox $)$.

Tabela 5.2. Caracterização física (SSV e IVL) do lodo durante a condição operacional de 125 $\mathrm{mg} \mathrm{N} / \mathrm{L}$.

Tabela 5.3 - Eficiências médias de remoção de DQO total e DQO filtrada e relação DQO filtrada/DQO total no efluente, durante a condição operacional de $125 \mathrm{mg} \mathrm{N} / \mathrm{L}$... 61

Tabela 5.4 - Variação dos valores de pH e potencial redox durante condição operacional de 125 $\mathrm{mgN} / \mathrm{L}$ no final de cada período anóxico e aeróbio aos $84 \mathrm{~d}, 156 \mathrm{~d}$ e $180 \mathrm{~d}$ de exeperimento.

Tabela 5.5 - Resultados de $\mathrm{pH}$ e $\mathrm{AB}\left(\mathrm{mg} \mathrm{CaCO}_{3}^{-} / \mathrm{L}\right)$ durante a condição operacional de $125 \mathrm{mg}$ $\mathrm{N} / \mathrm{L}$ com diferentes concentrações de OD. 66

Tabela 5.6 - Concentrações de nitrito e nitrato e eficiência de remoção nos reatores R1 e R2. 75

Tabela 5.7 - Resultados de monitoramento nas condições operacionais de $\mathrm{N}$-amoniacal de 125 e $250 \mathrm{mg} \mathrm{N} / \mathrm{L}$.

Tabela 5.8 - Condições de operação e resultados de remoção de nitrogênio durante condição operacional de $500 \mathrm{mg} \mathrm{N} / \mathrm{L}$

Tabela 5.9 - Velocidade específica de remoção de nitrogênio das condições operacionais estudadas.

Tabela 5.10 - Número Mais Provável de organismos nitrificantes nas condições operacionais estudadas. 


\section{LISTA DE QUADROS}

Quadro 3.1 - Concentrações máximas permissíveis para descarte.

Quadro 3.2 - Fontes de carbono utilizadas para desnitrificação em diferentes reatores. 12

Quadro 3.3 - Etapas do ciclo de operação de um reator aeróbio em batelada. 15

Quadro 3.4 - Relatos de inibição da nitratação à amônia livre. 19

Quadro 3.5 - Causas e ocorrência de acúmulo de nitrito e remoção de nitrogênio via nitrito em reatores alimentados com diferentes substratos. 28

Quadro 3.6 - Comparação entre velocidades de desnitrificação 30 
LISTA DE ABREVIATURAS

\begin{tabular}{|c|c|}
\hline $\mathrm{A} / \mathrm{M}$ & Alimento/microrganismo \\
\hline $\mathrm{A} / \mathrm{O}$ & Anóxico/aeróbio \\
\hline ANAMMOX & Anaerobic Ammonium Oxidation \\
\hline $\mathrm{C} / \mathrm{N}$ & Relação Carbono/Nitrogênio \\
\hline CONAMA & Conselho Nacional do Meio Ambiente \\
\hline DBO & Demanda Bioquímica de Oxigênio \\
\hline DQO & Demanda Química de Oxigênio \\
\hline DQOf & Demanda Química de Oxigênio filtrada \\
\hline EPA & Environmental Protection Agency \\
\hline ETA & Estração de Tratamento de Água \\
\hline IVL & Índice Volumétrico de Lodo \\
\hline N-Amoniacal & Nitrogênio na forma amoniacal \\
\hline ND & Não detectado \\
\hline NDS & Nitrificação e desnitrificação simultâneas \\
\hline OD & Oxigênio dissolvido \\
\hline OMS & Organização Mundial de Saúde \\
\hline $\mathrm{N}$ & Nitrogenio \\
\hline $\mathrm{N}-\mathrm{NH}_{4}^{+}$ & Nitrogênio na forma de íon amônio \\
\hline $\mathrm{N}-\mathrm{NO}_{2}^{-}$ & Nitrogênio na forma nitrito \\
\hline $\mathrm{N}-\mathrm{NO}_{3}^{-}$ & Nitrogênio na forma nitrato \\
\hline Nox & Nitrogênio oxidado \\
\hline N-NT & Nitrogênio na forma de nitrogênio total \\
\hline NMP & Número Mais Provável \\
\hline RBS & Reator em Batelada Seqüencial \\
\hline TRS & Tempo de Retenção de Sólidos \\
\hline SHARON & Single reactor High activity Ammonia Removal Over Nitrite \\
\hline SST & Sólidos Suspensos Totais \\
\hline SSV & Sólidos Suspensos Voláteis \\
\hline TRH & Tempo de retenção hidráulico \\
\hline
\end{tabular}




\section{SUMÁRIO}

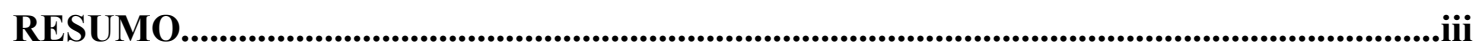

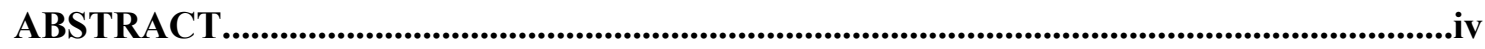

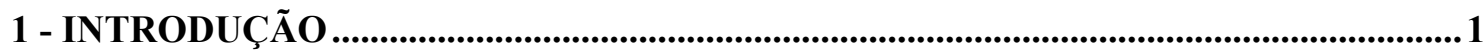

2 - OBJETIVOS

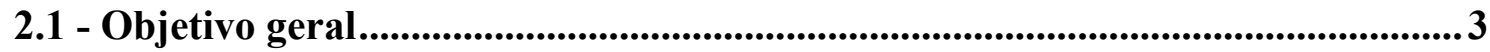

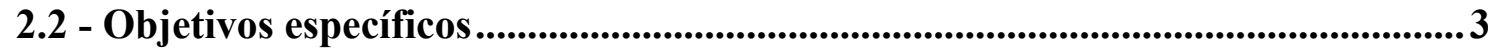

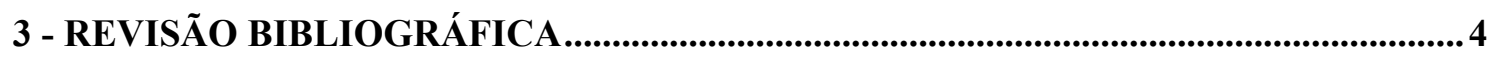

3.1 - Nitrificação e desnitrificação......................................................................4

3.1.1 - Nitrificação: microbiologia e aspectos físico-químicos..............................6

3.1.2 - Desnitrificação: microbiologia e aspectos físico-químicos.........................10

3.1.3 - Novos processos biológicos para remoção de nitrogênio...........................12

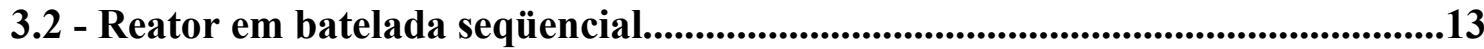

3.3 - Remoção biológica de nitrogênio utilizando aeração intermitente...................16

3.4 - Nitrificação e desnitrificação simultâneas..................................................................17

3.5 - Remoção biológica de nitrogênio através da nitrificação curta.........................18

3.6 - Estratégias de controle - potencial redox e pH...................................................32

3.7 - Conclusões da revisão bibliográfica..........................................................................35

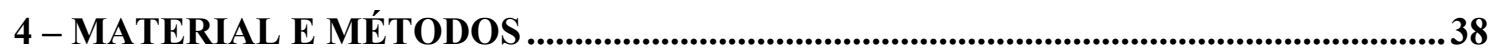

4.1 - Descrição dos equipamentos...................................................................................38

4.2 - Controle da concentração de oxigênio dissolvido no reator. ...................................40

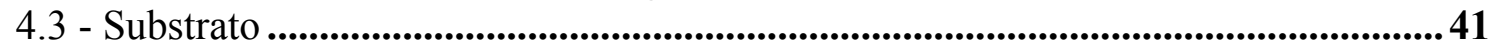

4.4 - Operação e acompanhamento do sistema ..........................................................42

4.3.1 - Descrição da operação .................................................................. 42

4.3.2 - Ensaio de verificação da velocidade de desnitrificação via nitrito e

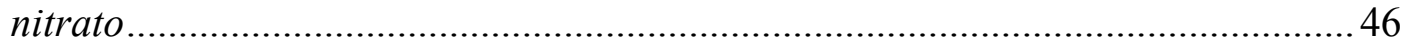

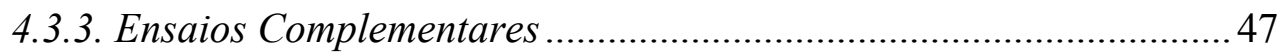

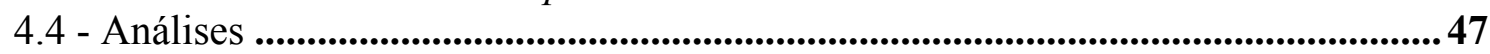

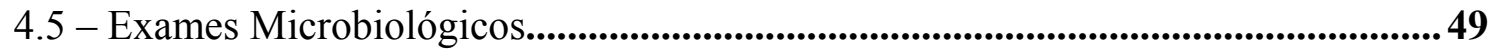

4.5.1 - Exames microscópicos .............................................................. 49

4.5.2 - Estimativa da população de organismos nitrificantes e

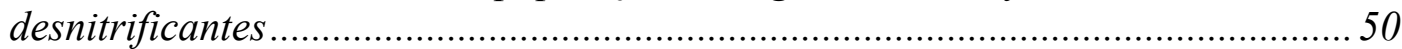

4.5.2 - Isolamento de cepas desnitrificantes nas amostras retiradas do

reator na condição operacional de $\mathrm{N}$-amoniacal afluente de 125, 250 e $500 \mathrm{mg}$

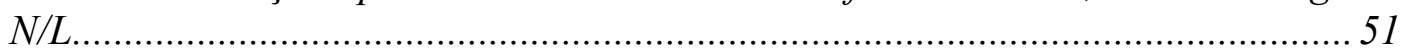

4.5.3 - Identificação filogenética das cepas isoladas.............................. 52

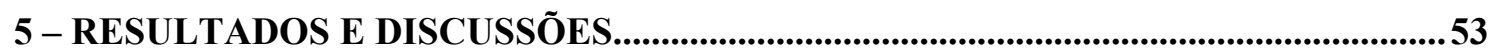

5.1 - Concentração de N-amoniacal afluente de $125 \mathrm{mg} \mathrm{N} / \mathrm{L}$ - considerações gerais.

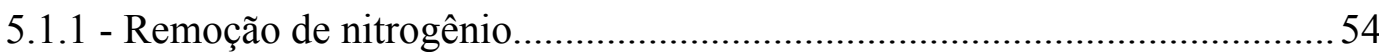

5.1.1.1 - Análise geral - monitoramento ................................................. 54 
5.1.1.2 - Análise pontual - Análise de uma batelada de 24 h. ..................58

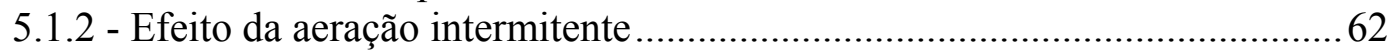

5.1.2.1 - Análise pontual - análise da batelada de 24h. ............................62

5.1.2.2 - Comportamento do $\mathrm{pH}$ e da alcalinidade ..................................65

5.1 .3 - Potencial redox e oxigênio dissolvido...................................................67

5.1.4 - Perfil temporal de um ciclo anóxico/aeróbio..........................................69

5.1.5 - Velocidade de desnitrificação via nitrito e via nitrato .............................. 72

5.2 - Concentração de $\mathrm{N}$-amoniacal afluente de $250 \mathrm{mg} \mathrm{N} / \mathrm{L}$....................................75

5.2.1 - Remoção de nitrogênio e efeito da aeração intermitente .......................... 75

5.2.1.1 - Análise geral - monitoramento ............................................. 75

5.2.1.2 - Análise pontual - análise da batelada de $24 \mathrm{~h}$............................ 76

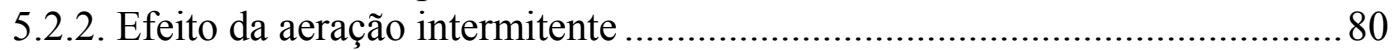

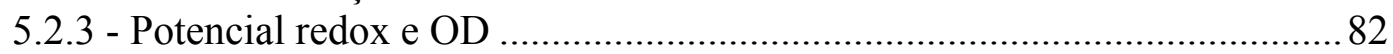

5.2.4 - Perfil temporal de um ciclo anóxico/ aeróbio de 4 h................................ 83

5.3 - Comparação entre condições operacionais de $\mathrm{N}$-amoniacal afluente - 125 e

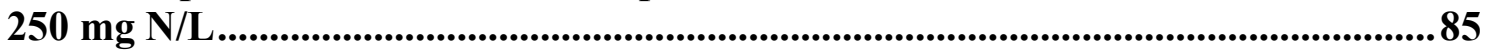

5.4- Concentração de $\mathrm{N}$-amoniacal de $500 \mathrm{mg} \mathrm{N} / \mathrm{L}$.............................................88

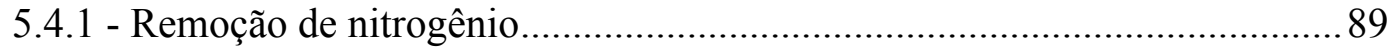

5.4.1.1- Análise geral - monitoramento .............................................. 89

5.4.1.2 Obtenção do perfil temporal - análise de uma batelada de 24 h....94

5.4.2 - Variação dos valores de $\mathrm{pH}$.....................................................................96

5.4.3 - Potencial redox e oxigênio dissolvido ......................................................98

5.4.4 - Perfil temporal de um ciclo anóxico/ aeróbio de 2h/9h........................... 100

5.5 - Velocidade de remoção de nitrogênio............................................................... 102

5.6 - Ensaios adicionais .......................................................................................103

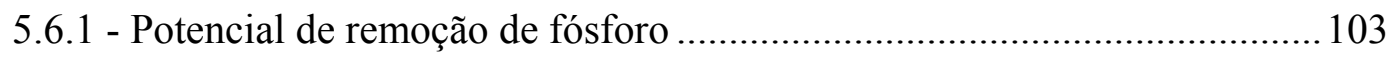

5.6.2 - Uso alternativo de etanol para desnitrificação........................................ 105

5.7 - Exames microbiológicos .............................................................................106

5.7.1 - Estimativa da microbiota nitrificante e desnitrificante ............................ 107

5.7.2 - Isolamento e seqüenciamento do DNA 16S de cepas bacterianas das amostras retiradas durante a operação com concentração de $\mathrm{N}$-amoniacal afluente

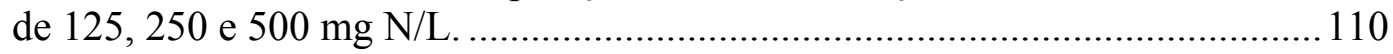

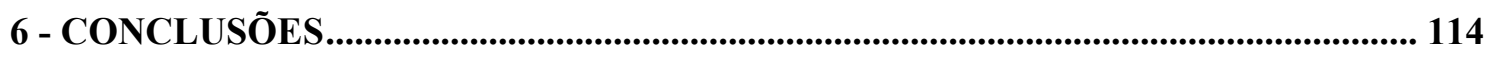

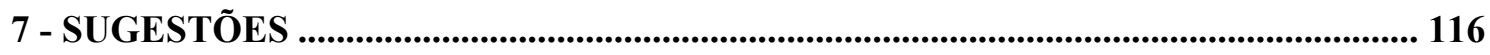

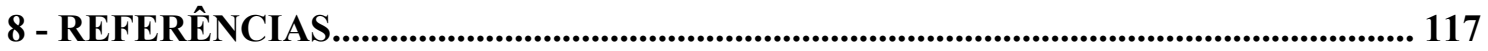

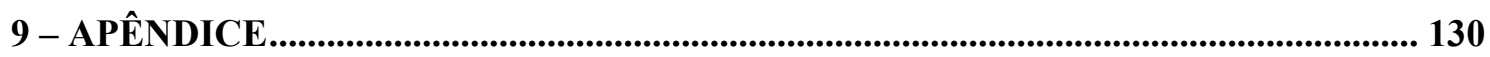





\section{1 - INTRODUÇÃO}

A remoção biológica de nitrogênio através de processos de nitrificação e desnitrificação, considerada como processo integrante do tratamento terciário de efluente de esgoto sanitário, tem sido amplamente utilizada em sistemas em escala real, podendo ser considerada tecnologia estabelecida em estações de tratamento de esgotos baseadas nos sistemas de lodos ativados e suas modificações.

No entanto, o desenvolvimento recente desses processos tem abordado conceitos inovadores, como a nitrificação curta via nitrito, principalmente no caso de elevadas concentrações de nitrogênio.

Essa alternativa origina-se no fato de que o nitrito é produto intermediário tanto do processo de nitrificação quanto de desnitrificação. Esse "curto-circuito" é executado através da inibição da nitratação e conseqüente acúmulo de nitrito, sendo a desnitrificação efetuada a partir do nitrito.

Em comparação com os métodos tradicionais de remoção de nitrogênio, a aplicação bem sucedida desse processo pode resultar em economia significativa, pois pode permitir a redução de energia gasta para aeração, além da redução da quantidade de fonte de carbono necessária e de alcalinidade. Permite, também, encurtar o tempo de reação tanto na nitrificação quanto na desnitrificação e reduzir o excesso de lodo produzido (TURK e MAVINIC, 1989; MUNCH et al. 1996; CASTRO DANIEL, 2005).

Diversas águas residuárias industriais contêm altas concentrações de nitrogênio amoniacal, concentrações de matéria orgânica relativamente baixas, comparadas com as concentrações de compostos nitrogenados, além de outros constituintes, como sulfatos, por exemplo. A presença de matéria orgânica, mesmo em baixa concentração, pode ser útil na etapa de desnitrificação, uma vez que compostos orgânicos podem ser utilizados como doadores de elétrons para tal processo.

No entanto, a etapa de nitrificação pode resultar na oxidação não apenas do 
nitrogênio amoniacal a nitrito, mas também na oxidação da matéria orgânica. Tal fato pode levar à necessidade de adição de fonte de carbono exógena na etapa de desnitrificação.

Reatores operados em bateladas alimentadas com enchimento no período anóxico e sob aeração intermitente podem permitir o melhor aproveitamento das fontes de carbono nas etapas de desnitrificação. Caso seja possível operar reatores desse tipo no tratamento de efluentes contendo concentrações elevadas de nitrogênio amoniacal e contendo matéria orgânica em baixa concentração, a economia resultante da diminuição da quantidade de fonte de carbono exógena necessária pode ser significativa.

Embora a literatura seja abundante com relação aos processos de nitrificação e desnitrificação, inclusive em reatores operados em bateladas seqüenciais, poucos trabalhos tratam da remoção de nitrogênio de águas residuárias contendo concentrações elevadas de nitrogênio amoniacal com as características anteriormente descritas. Não foi também encontrada nenhuma referência sobre reatores operados em batelada alimentada para tratamento desse tipo de água residuária.

Portanto, este trabalho aborda tema de grande interesse para o desenvolvimento de processos de remoção de nitrogênio de águas residuárias que apresentam, como principais características, concentrações elevadas de nitrogênio amoniacal e baixas concentrações de matéria orgânica. 


\section{2 - OBJETIVOS}

\section{1 - Objetivo geral}

Avaliar a capacidade de remoção de alta concentração de nitrogênio em reator contendo biomassa em suspensão operado em regime de batelada alimentada e submetido a condições de aeração intermitente.

\section{2 - Objetivos específicos}

Avaliar a eficiência do processo para concentrações crescentes de $\mathrm{N}$-amoniacal.

Avaliar os parâmetros de controle dos pontos de início e término da nitrificação e desnitrificação. Verificar a necessidade de ajustes dos ciclos na duração das etapas aeradas e não aeradas.

Verificar as condições para ocorrência de acúmulo de nitrito e para a inibição das bactérias oxidantes de nitrito.

Quantificar as populações de organismos nitrificantes e desnitrificantes em cada condição operacional.

Identificar as cepas isoladas nas concentrações de N-amoniacal com a utilização de técnicas de Biologia Molecular. 


\section{3 - REVISÃO BIBLIOGRÁFICA}

Esse item apresenta primeiramente os aspectos microbiológicos e físicoquímicos referentes à nitrificação e desnitrificação, seguido da apresentação de novos processos microbianos na remoção de nitrogênio. Os itens seguintes são: o reator a ser utilizado; aspectos da operação sob aeração intermitente; o conceito de nitrificação e desnitrificação simultâneas e de remoção biológica de nitrogênio através da nitrificação curta e a apresentação de estratégias de controle da remoção de nitrogênio.

\section{1 - Nitrificação e desnitrificação}

O elemento nitrogênio (em todas as formas), bem como os fosfatos, provenientes de sistemas de esgotos sanitários e de águas residuárias industriais, quando são descartados em corpos de água, tornam-se nutrientes disponíveis para plantas aquáticas, sendo os principais responsáveis pela eutrofização de lagos e represas. Fontes de nitrato em águas subterrâneas são os fertilizantes químicos adicionados aos solos (sais de amônio, amônia anidro e uréia), considerando-se que geralmente, nitrato e nitrito são adsorvidos em muitos solos e são sujeitos à lixiviação, podendo atingir o lençol freático. Adicionalmente, a ocorrência de nitratos em águas de abastecimento pode ser responsável pela incidência da doença infantil denominada metemoglobinemia, ou doença azul. Como o pH do estômago das crianças favorece produção de nitrito, o nitrito formado liga-se à hemoglobina, não permitindo transferência de oxigênio.

Por outro lado, o nitrogênio amoniacal, além de ser tóxico a algumas espécies aquáticas, é também facilmente oxidado por organismos nitrificantes que consomem o oxigênio dissolvido, o que pode tornar a vida aquática aeróbia inviável. No caso do nitrato, também pode haver formação de nitrosaminas que são carcinogênicas, mutagênicas e teratogênicas (HISCOCK et al., 1991). 
Devido a estes problemas, tornou-se necessário a definição dos limites de concentração destes compostos. Os limites de concentração permissível de formas de nitrogênio para descarte em corpos de água são apresentados no Quadro 3.1.

Quadro 3.1 - Concentrações máximas permissíveis para descarte

\begin{tabular}{|c|c|c|}
\hline País & Concentração limite & Referência \\
\hline Brasil & 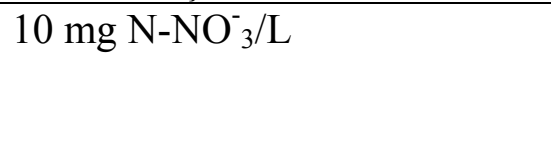 & $\begin{array}{lr}\text { BRASIL } & (2005) ; \\
\text { BRASIL/ } & \text { FUNASA } \\
(2001) & \end{array}$ \\
\hline Comunidade & $50{\mathrm{mg} \mathrm{N}-\mathrm{NO}^{-} / \mathrm{L}}^{-}$ & MATEJU et al. (1992) \\
\hline Européia/OMS & $\begin{array}{l}11,3 \mathrm{mg} \mathrm{N}-\mathrm{NO}_{3}^{-} / \mathrm{L} \text { para água } \\
\text { potável }\end{array}$ & $\begin{array}{l}\text { HISCOCK et al. (1991); } \\
\text { KIM et al. (2003) }\end{array}$ \\
\hline Dinamarca & $\begin{array}{l}0,025 \mathrm{mg} \mathrm{N}^{-\mathrm{NH}_{4}}{ }^{+} / \mathrm{L} \text { para } \\
\text { descarga em rios com peixes }\end{array}$ & HENZE et al. (1997 \\
\hline Itália & $20{\mathrm{mg} \mathrm{N}-\mathrm{NO}^{-}}_{3} / \mathrm{L}$ & TILCHE et al. (1999) \\
\hline Coréia & $\begin{array}{l}60 \mathrm{mg} \mathrm{N}-\mathrm{NT} / \mathrm{L} \text { no efluente e } 10 \\
\mathrm{mg} \mathrm{N}-\mathrm{NO}_{3}^{-} / \mathrm{L} \text { para água de } \\
\text { consumo }\end{array}$ & CHOI et al. (2004) \\
\hline EUA/EPA & 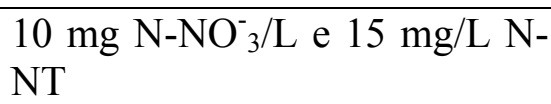 & MATEJU et al. (1992) \\
\hline
\end{tabular}

OMS= Organização Mundial de Saúde.

A concentração de $11,3 \mathrm{mg} \mathrm{N}-\mathrm{NO} \overline{3} / \mathrm{L}$ referida pela Comunidades do Conselho Europeu está associada diretamente a um estudo que relatou ocorrência de casos de metemoglobinemia infantil nessa concentração (HISCOCK et al., 1991). Portanto, a concentração máxima permissível de nitrato $(10 \mathrm{mg} \mathrm{N}-\mathrm{NO} \overline{3} / \mathrm{L})$ em água de consumo está relacionado com a incidência dessa doença, segundo os padrões da EPA, sendo que a maioria do países (inclusive o Brasil) segue os mesmos padrões.

No Brasil, há três tipos de padrões relacionados à qualidade da água:

- padrões de lançamento no corpo receptor;

- padrões de qualidade do corpo receptor;

- padrões de potabilidade (portaria 1469/2001, do Ministério da Saúde).

Em função dos usos da água, a resolução CONAMA 20/1986 (atualizada pela resolução 357/2005) criou nove classes em função da qualidade a ser mantida no corpo de água. Essa qualidade é expressa na forma de padrões estabelecidos pela Resolução CONAMA, que também apresenta padrões para o lançamento de efluentes nos corpos de água assim como padrões de balneabilidade. A resolução 20/1986 considera como

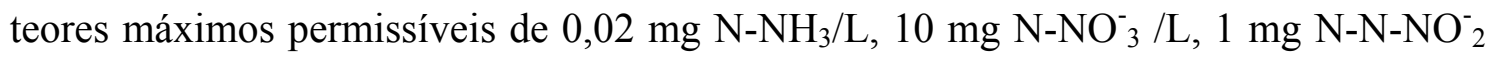
$/ \mathrm{L}$ para as classes 1, 2 e 3, enquanto o nitrogênio amoniacal vai aparecer na lista apenas 
na classe 3 com o teor máximo permissível de $1 \mathrm{mg} \mathrm{N} / \mathrm{L}$.

Os padrões de qualidade do corpo de água e de lançamento de efluentes estão inter-relacionados no sentido de que, um efluente além de satisfazer os padrões de lançamento, deve proporcionar condições tais no corpo receptor, de tal forma que a qualidade do mesmo se enquadre dentro dos padrões de qualidade do corpo receptor.

Os compostos nitrogenados são encontrados em altas concentrações nas águas residuárias industriais (processamento de alimentos: fabricação de pectina, farinha de peixe, carnes e embutidos, refinarias de petróleo, processos metalúrgicos, tintas, fertilizantes). Nos esgotos sanitários em geral, as concentrações são baixas, com a predominância de $\mathrm{N}$-amoniacal (60\%) e N-orgânico (40\%), sendo que a fração de nitritos e nitratos corresponde a menos de 1\% (BARNES e BLISS, 1983; SEDLAK, 1991).

Os nutrientes podem ser removidos através de processos físico-químicos e biológicos, sendo que os primeiros são mais dispendiosos, exigem manutenção mais intensiva e podem ter impactos ambientais secundários significativos (tais como a liberação de amônia no processo de stripping). Por isso, os processos biológicos têm sido a melhor alternativa para remoção de tais compostos, com o uso de sistemas físicoquímicos para o polimento do efluente (SEDLAK, 1991).

A remoção biológica de nitrogênio pode ser conseguida através dos processos de nitrificação e desnitrificação, sendo o N-amoniacal (amônio + amônia) oxidado a nitrito, sob condições aeróbias (nitritação) e, seqüencialmente, a nitrato (nitratação). Este é, subseqüentemente, reduzido a gás nitrogênio $\left(\mathrm{N}_{2}\right)$ sob condições anóxicas (desnitrificação). Essas condições podem ser atingidas em seqüência espacial (sistema de dois estágios) ou temporal das fases anaeróbia, anóxica e aeróbia.

\subsection{1 - Nitrificação: microbiologia e aspectos físico-químicos}

A nitrificação convencional é um processo autotrófico, isto é, a energia para crescimento bacteriano é derivada da oxidação de compostos inorgânicos de nitrogênio, (quimioautotróficos ou quimiolitoautotróficos) principalmente íon amônio $\left(\mathrm{NH}_{4}^{+}\right)$, nitrito $\left(\mathrm{NO}_{2}^{-}\right)$e nitrato $\left(\mathrm{NO}_{3}^{-}\right)$, usando dióxido de carbono $\left(\mathrm{CO}_{2}\right)$ como fonte de carbono inorgânico para síntese de novas células (METCALF e EDDY, 1991). Madigan et al. (1997) consideram que organismos autotróficos são aqueles que são capazes de obter 
todo o carbono que necessitam de fontes inorgânicas.

A natureza estritamente biológica da nitrificação e os organismos envolvidos foram identificados em 1877 por Schoesing e Muntz. Em 1879, Warrington ${ }^{1}$ (1879, apud ANTHONISEN et al. 1976) deduziu que a nitrificação era um processo de duas etapas envolvendo dois diferentes grupos de microrganismos. Percy e Grace Frankland isolaram culturas puras de bactérias oxidantes de N-amoniacal e nitrito. Em 1888, Sergei Winogradsky² identificou o gênero Nitrosomonas, e Nitrosococcuse Nitrobacter.

Dois grupos distintos de bactérias quimiolitotróficas denominadas de oxidantes de amônio e oxidantes de nitrito são consideradas como responsáveis pela nitrificação no ambiente. Esses organismos estão agrupados na família Nitrobacteriaceae que compreendem bactérias Gram-negativas categorizados por sua forma, tamanho, arranjo da membrana citoplasmática, relação de bases de DNA e capacidade metabólica (BOCK et al., 1991; MADIGAN et al., 1997).

A oxidação de N-amoniacal geralmente é atribuída a Nitrosomonas (principalmente N. europea e N. monocella) e Nitrosospira. Enquanto que a oxidação do nitrito é feita por Nitrobacter (N. agilis e N. winogradskyi) e Nitrospira (BARNES e BLISS, 1983; VAN LOOSDRECHT e JETTEN, 1998).

Madigan et al. (1997) acrescentam a essas, outras bactérias oxidantes de Namoniacal, tais como: Nitrosococcus, Nitrosolobus e Nitrosovibrio e como oxidantes de $\mathrm{NO}_{2}^{-}$, Nitrospina e Nitrococcus.

O processo de nitrificação é usualmente expresso como oxidação do íon amônio devido à predominância da forma ionizada $\left(\mathrm{NH}_{4}{ }^{+}\right)$em valores de $\mathrm{pH}$ dentro da faixa ideal da nitrificação.

As proteobactérias oxidantes de $\mathrm{N}$-amoniacal podem obter sua energia para crescimento tanto da oxidação aeróbia como anaeróbia. Suzuki et al. (1974), Hooper (1984), Bock et al. (1991) e Schmidt et al. (2003) relataram a possibilidade de que amônia $\left(\mathrm{NH}_{3}\right)$ e não o íon amônio $\left(\mathrm{NH}_{4}^{+}\right)$seja o substrato para o processo de oxidação.

Segundo relato de Bock et al. (1991), a enzima oxidante de N-amoniacal está localizada na membrana citoplasmática, que é altamente permeável à amônia $\left(\mathrm{NH}_{3}\right)$, mas a não ao amônio $\left(\mathrm{NH}_{4}^{+}\right)$, justificando porque a amônia é usada como substrato

\footnotetext{
1 WARRINGTON,R. (1879). On-nitrification. Part II. Journal Chemical Society, v.35, p.429 apud ANTHONISEN, A.C.; LOEHR, R.C.; PRAKASAM, T.B.S.; SRINATH, E.G. (1976). Inhibition of nitrification by ammonia and nitrous acid. JWPCF, Alexandria, v.48, n.5, p.835-52.

${ }^{2}$ WAKSMAN, S. (1946). Sergei Nikolavevitch Winogradsky: The study of great bacteriologist. Soil Science, v.62, p.197-226.
} 
(WIESMAN, 1994).

A oxidação de $\mathrm{N}$-amoniacal é a etapa limitante do processo, pois sua velocidade de oxidação é relativamente mais lenta do que a velocidade de oxidação do nitrito. Em processos convencionais, o nitrito $\left(\mathrm{NO}_{2}\right)$ ) somente aparecerá em elevadas concentrações (maiores que $1 \mathrm{mg} \mathrm{N} / \mathrm{L}$ ) quando o processo considerado se encontrar em estado transiente, motivado por variação de cargas, partida e arraste da biomassa, ou outros problemas operacionais (HENZE et al., 1997).

Os principais produtos do processo de remoção biológica de nitrogênio são nitrito e nitrato sob condições aeróbias e $\mathrm{N}_{2}$, nitrito, e óxido nítrico sob condições anóxicas. O primeiro intermediário da oxidação de $\mathrm{N}$-amoniacal é a hidroxilamina (SCHMIDT et al., 2003).

A temperatura, o pH, a concentração de oxigênio dissolvido (OD), a concentração e a composição do substrato (concentração de amônia, relação DBO/NTK), o tempo de retenção de sólidos (TRS), bem como a fração de bactérias nitrificantes presentes no sistema, são parâmetros importantes na cinética da nitrificação (HENZE et al., 1997).

A velocidade de nitrificação, em lodos ativados, diminui com o decréscimo da temperatura, cujo valor ótimo está entre 25 e $35^{\circ} \mathrm{C}$ (SURAMPALLI et al., 1997). A velocidade de nitrificação dobra ou triplica quando a temperatura aumenta de $10^{\circ} \mathrm{C}$ numa faixa de 5 a $30^{\circ} \mathrm{C}$ (RITTMAN e MCCARTY ${ }^{3}, 2001$ apud BAE et al., 2002). Ford et al. (1980) sugeriram que a faixa ótima está entre 30 e $36^{\circ} \mathrm{C}$.

O pH ótimo para nitrificação está na faixa de 7,2 a 9,0 (METCALF e EDDY, 1991). Segundo Surampalli et al. (1997), em valores de $\mathrm{pH}$ abaixo de 7 ou acima de 9, a velocidade de nitrificação é menor que $50 \%$ da ótima. $\mathrm{O} \mathrm{pH}$ influencia a maior concentração da amônia na forma ionizada (amônio $-\mathrm{NH}_{4}^{+}$) ou na forma não ionizada (amônia livre - $\mathrm{NH}_{3}$ ), sendo que a amônia livre inibe as bactérias oxidantes de amônia.

A alcalinidade é consumida pela oxidação de $\mathrm{N}$-amoniacal (consumo de 8,64mg de $\mathrm{HCO}_{3}^{-}$por $\mathrm{mg}$ de amônio $\left(\mathrm{NH}_{4}^{+}\right)$oxidado ou $\left.7,14 \mathrm{mg} \mathrm{CaCO}_{3}^{-}\right)$e o valor de $\mathrm{pH}$ diminui se não houver meios de controle do $\mathrm{pH}$.

A alcalinidade consumida pelas bactérias nitrificantes pode ser calculada pelas seguintes Equações (BARNES e BLISS, 1983; METCALF e EDDY, 1991):

\footnotetext{
${ }^{3}$ RITTMAN, B.E.; MCCARTY, P.L. (2001). Environmental Biotechnology: Principles and Applications. McGraw-Hill, NY. apud BAE, W.; BAEK, S.; CHUNG, J.; LEE, Y. (2002). Optimal operational factors for nitrite accumulation in batch reactors. Biodegradation, Dordrecht, v.12, p.359-66.
} 
para Nitrosomonas ou bactérias oxidantes de N-amoniacal:

$55 \mathrm{NH}_{4}^{+}+76 \mathrm{O}_{2}+109 \mathrm{HCO}_{3}^{-} \rightarrow \mathrm{C}_{5} \mathrm{H}_{7} \mathrm{O}_{2} \mathrm{~N}+54 \mathrm{NO}_{2}^{-}+57 \mathrm{H}_{2} \mathrm{O}+104 \mathrm{H}_{2} \mathrm{CO}_{3}+$ energia $(240-350 \mathrm{~kJ})$

para Nitrobacter ou bactérias oxidantes de nitrito:

$400 \mathrm{NO}_{2}^{-}+\mathrm{NH}_{4}^{+}+4 \mathrm{H}_{2} \mathrm{CO}_{3}+\mathrm{HCO}_{3}^{-}+195 \mathrm{O}_{2} \rightarrow \mathrm{C}_{5} \mathrm{H}_{7} \mathrm{O}_{2} \mathrm{~N}+3 \mathrm{H}_{2} \mathrm{O}+400 \mathrm{NO}_{3}^{-}$ + energia $(65-90 \mathrm{~kJ})$.

Equação global para a nitrificação:

$\mathrm{NH}_{4}^{+}+1,86 \mathrm{O}_{2}+1,98 \mathrm{HCO}_{3}^{-} \rightarrow 0,02 \mathrm{C}_{5} \mathrm{H}_{7} \mathrm{O}_{2} \mathrm{~N}+0,98 \mathrm{NO}_{3}^{-}+1,04 \mathrm{H}_{2} \mathrm{O}+1,88$ $\mathrm{H}_{2} \mathrm{CO}_{3}$ +energia

Dessas equações, percebe-se que há um consumo maior de oxigênio e alcalinidade na primeira fase da nitrificação, ou seja, na fase de nitritação. A energia liberada nessas reações é usada pelos organismos nitrificantes para síntese a partir das fontes de carbono inorgânico, como dióxido de carbono, bicarbonato e carbonato (BARNES e BLISS, 1983).

Estequiometricamente:

Consumo de oxigênio $=\underline{1,86 \mathrm{~mol} \mathrm{O}_{2}} \frac{\mathrm{x} 32 \mathrm{~g} \mathrm{O}}{2} / \mathrm{mol}=4,25 \mathrm{~g} \mathrm{O}_{2} / \mathrm{g} \mathrm{N}^{-\mathrm{NH}^{+}}{ }_{4}$ na nitrificação $1 \mathrm{~mol} \mathrm{~N}-\mathrm{NH}_{4}^{+} \times 14 \mathrm{~g} \mathrm{~N} / \mathrm{mol}$

Consumo de alcalinidade $=\underline{1,98 \mathrm{~mol} \mathrm{HCO}^{-}} \underline{\underline{x}} \underline{\times 1 \mathrm{~g} \mathrm{HCO}^{-}} \underline{3} \underline{\underline{\mathrm{mol}}}=8,635 \mathrm{~g} \mathrm{O}_{2} / \mathrm{g} \mathrm{N}^{-\mathrm{NH}^{+}}{ }_{4}$ na nitrificação $1 \mathrm{~mol} \mathrm{~N}-\mathrm{NH}_{4}^{+}$× $14 \mathrm{~g} \mathrm{~N} / \mathrm{mol}$

As velocidades máximas de nitrificação ocorrem em concentrações de OD acima de $2 \mathrm{mg} \mathrm{O} / \mathrm{L}$. $\mathrm{O}$ aumento da concentração de biomassa nitrificante também aumenta a velocidade de nitrificação.

A nitrificação de águas residuárias com elevada concentração de nitrogênio (maior que $60 \mathrm{mg} \mathrm{N} / \mathrm{L}$ ) requerem: (i) alcalinidade suficiente para tamponar a acidificação e (ii) bicarbonato como substrato para biomassa autotrófica (WETT e RAUCH, 2003). No final da aeração, se os valores de $\mathrm{pH}$ estiverem baixos $(\mathrm{pH}<7,0)$ pode haver decréscimo do carbono inorgânico disponível ocasionado pelo stripping de $\mathrm{CO}_{2}$, provocado pela aeração, o que justifica o controle de $\mathrm{pH}$ em sistemas nitrificantes.

Metcalf e Eddy (1991) consideram que a habilidade dos processos de lodos ativados de nitrificar é dependente da relação $\mathrm{DBO}_{5} / \mathrm{NTK}$ (demanda bioquímica de oxigênio/ nitrogênio total Kjeldahl), sendo que, para valores superiores a 5, classifica-se o processo como combinado de oxidação de carbono e nitrificação. Quando o valor dessa relação é inferior a 3, o processo é considerado somente como de nitrificação. A diminuição da relação $\mathrm{DBO}_{5} / \mathrm{NTK}$ também aumenta a porcentagem de nitrificantes e assim a velocidade de nitrificação (SURAMPALLI et al., 1997). 
Populações nitrificantes podem também estar aderidas às superfícies, pois Gray (1990) relatou esse tipo de ocorrência em sistema de lodos ativados na forma de agregados de biomassa floculenta. Tais aderências são relacionadas com aumento da atividade nitrificante e podem promover a eficiência do sistema nitrificante (DIAB e SHILO, 1988).

\subsection{2 - Desnitrificação: microbiologia e aspectos físico-químicos}

O processo de desnitrificação pode ser realizado por várias bactérias quimiorganotróficas, litoautotróficas e fototróficas e por alguns fungos (SCHMIDT et al., 2003). Muitas espécies são capazes de usar oxigênio em metabolismo aeróbio e na ausência de oxigênio reduzem nitrato ( $\mathrm{NO}_{3}$ ) em metabolismo anóxico. Desse modo, a mesma biomassa pode ser usada em processo aeróbio/anóxico para remoção de carbono e nitrato $\left(\mathrm{NO}_{\overline{3}}\right)$. O termo anóxico refere-se a uma via metabólica que é uma modificação da via aeróbia (METCALF e EDDY, 1991).

Quase todas as bactérias desnitrificantes são capazes de usar nitrito $(\mathrm{NO} \overline{2})$ no lugar de nitrato ( $\mathrm{NO} \overline{3}$ ) como aceptor de elétrons e vários compostos orgânicos diferentes como doadores de elétrons ou fonte de energia (WIESMAN, 1994). Metcalf e Eddy (1991) citam como bactérias desnitrificantes, as bactérias dos seguintes gêneros: Achromobacter, Aerobacter, Alcaligenes, Bacillus, Brevibacterium, Flavobacterium, Lactobacillus, Micrococcus, Proteus, Pseudomonas e Spirillum. Além dessas bactérias, Mateju et al. (1992) ainda citam: Azospirillum, Beggiatoa, Chromobacterium, Clostridium, Dessulfovibrio, Erythrobacter, Galionella, Helobacterium, Halomonas, Hypomicrobium, Neisseria, Paracoccus, Propionibacterium, Rhizobium, Thiobacillus, Thiosphaera, Vibrio e Xanthomonas.

Bactérias do gênero Paracoccus, Thiobacillus, Thiosphaera e outros podem efetuar desnitrificação autotrófica com uso de $\mathrm{CO}_{2}$ ou bicarbonato como fonte de energia e compostos de hidrogênio e de enxofre $\left(\mathrm{S}^{0}, \mathrm{~S}^{2-}, \mathrm{S}_{2} \mathrm{O}_{3}{ }^{2-}, \mathrm{S}_{2} \mathrm{O}_{2}{ }^{2-}\right.$ ou $\left.\mathrm{SO}_{3}{ }^{2-}\right)$ como fonte de energia, enquanto outras utilizam ferro como fonte de energia (MATEJU et al., 1992).

A velocidade de desnitrificação é afetada por fatores ambientais como: temperatura, $\mathrm{pH}$ e concentração de OD. A desnitrificação ocorre em temperaturas na faixa de 10 a $30^{\circ} \mathrm{C}$. O pH ótimo está na faixa de 6,5 a 8,0 (METCALF e EDDY, 1991). 
A velocidade de desnitrificação é reduzida em $\mathrm{pH}$ abaixo de 6,0 e acima de 9,0 (SURAMPALLI et al., 1997), principalmente devido ao aumento da produção de óxidos nítricos que são inibidores do processo. Em pH abaixo de 7, pode haver aumento da produção de $\mathrm{N}_{2} \mathrm{O}$ como produto final da desnitrificação (HENZE et al., 1997)

A presença de oxigênio inibe o processo de desnitrificação (em concentrações superiores a $1 \mathrm{mg} / \mathrm{L} \mathrm{O}_{2}$, SURAMPALLI et al., 1997) e a concentração de oxigênio que é considerada crucial é a que está dentro dos flocos ou biofilmes e não a que é medida na fase líquida (HENZE et al., 1997).

Enquanto a nitrificação consome alcalinidade, a desnitrificação produz alcalinidade na proporção de 1 equivalente grama de alcalinidade por mol de $\mathrm{N}$ (HENZE et al., 1997).

A água residuária a ser desnitrificada deve conter carbono orgânico suficiente para prover fonte de energia para conversão de nitrato (NO $\overline{3}$ ) a $\mathrm{N}_{2}$ gasoso pela bactéria. O requerimento de carbono pode ser provido por meio de fonte interna (recirculação de parte da água residuária, material celular) ou externa (aminoácidos, etanol, acetato, sucinato, acetona, glicose, óleo de oliva e benzoato) (METCALF e EDDY, 1991; HENZE et al., 1997).

Henze et al. (1997) relataram valores de $\mathrm{C} / \mathrm{N}$ ótimo de 4 a $5 \mathrm{~kg} \mathrm{DQO} / \mathrm{kg} \mathrm{N}$ no caso de matéria orgânica e de 3,1 a 3,7 kg DQO/ $\mathrm{kg} \mathrm{N}$ no caso de ácido acético como fonte de carbono. Barnard ${ }^{4}$ (1992 apud POCHANA e KELLER, 1999) relatou que a desnitrificação completa pode ser atingida em esgoto sanitário com relação DQO/NTK de 7. Para fontes de carbono prontamente biodegradáveis, Narcis et al. (1979) recomendaram que relação $\mathrm{DQO} / \mathrm{NO}_{3}^{-}$de 3 a 6 (massa/massa) possibilita completa redução de nitrato a nitrogênio elementar.

Sistemas biológicos similares podem ter diferentes relações $\mathrm{C} / \mathrm{N}$ ótimas se usadas para tratar diferentes águas residuárias sob condições ambientais e em reatores distintos, como pode ser observado no Quadro 3.2. Por isso, relação C/N ótima para sistemas desnitrificantes biológicos para tratar águas residuárias específicas deve ser determinada experimentalmente.

${ }^{4}$ BARNARD, J.L. (1992). Design and retrofit of wastewater treatment plants for biological nutrient removal. Pensylvania, Technomic Publishing apud POCHANA, K., KELLER, J. (1999). Study of factors affecting simultaneous nitrification and denitrification (SND). Water Science Technology, Oxford, v.39, n.6, p.61-68. 
Quadro 3.2 - Fontes de carbono utilizadas para desnitrificação em diferentes reatores.

\begin{tabular}{|c|c|c|c|c|}
\hline Referência & Tipo de reator & $\begin{array}{l}\text { Fonte de } \\
\text { carbono }\end{array}$ & $\begin{array}{c}\text { Forma de } \mathrm{N} \\
\text { a ser } \\
\text { desnitrificada }\end{array}$ & Relação ótima \\
\hline $\begin{array}{l}\text { TURK e } \\
\text { MAVINIC (1987) }\end{array}$ & batelada & acetato & $\mathrm{NO}_{2}^{-}$ & $\mathrm{DQO} / \mathrm{N}=2$ \\
\hline $\begin{array}{l}\text { ABELING e } \\
\text { SEYFRIED (1992) }\end{array}$ & $\begin{array}{c}\text { Processo A/O } \\
\text { (anóxico/aeróbio) }\end{array}$ & & $\begin{array}{l}\mathrm{NO}_{3}^{-} \\
\mathrm{NO}_{2}^{-}\end{array}$ & $\begin{array}{l}\mathrm{DQO} / \mathrm{N}=2,08 \\
\mathrm{DQO} / \mathrm{N}=1,56\end{array}$ \\
\hline $\begin{array}{l}\text { ÇEÇEN e } \\
\text { GONENÇ (1992) }\end{array}$ & Lodos ativados & melado & $\mathrm{NO}_{\mathrm{x}}$ & $\mathrm{DQO} / \mathrm{N}=5$ \\
\hline KIM et al (1992) & Reator contínuo & amido & $\mathrm{NO}_{3}^{-}$ & $\mathrm{C} / \mathrm{N}=2,58$ \\
\hline $\begin{array}{l}\text { MATEJU et al. } \\
\text { (1992) }\end{array}$ & & acetato & $\mathrm{NO}_{3}^{-}$ & $\mathrm{DQO} / \mathrm{N}=3,74$ \\
\hline $\begin{array}{l}\text { KUBA et al. } \\
(1993)\end{array}$ & $\begin{array}{l}\text { Processo A/O } \\
\text { (anóxico/ óxico) }\end{array}$ & acetato & $\mathrm{NO}_{\mathrm{x}}$ & $\mathrm{C} / \mathrm{N}=3,4$ \\
\hline TAM et al. (1994) & & metanol & $\mathrm{NO}_{\mathrm{x}}$ & $\mathrm{DQ} / \mathrm{NO}_{\mathrm{x}}=2,48$ \\
\hline $\begin{array}{l}\text { BERNET et al. } \\
\text { (1996) }\end{array}$ & Frasco batelada & $\begin{array}{c}\text { águas } \\
\text { residuárias } \\
\text { de } \\
\text { suinocultura }\end{array}$ & $\begin{array}{l}\mathrm{NO}_{3}^{-} \\
\mathrm{NO}_{3}^{-}\end{array}$ & $\begin{array}{l}\mathrm{C} / \mathrm{N}=2,88 \\
\mathrm{C} / \mathrm{N}=4,16\end{array}$ \\
\hline $\begin{array}{l}\text { AESOY et al. } \\
(1998)\end{array}$ & $\begin{array}{l}\text { Reator de } \\
\text { biofilme }\end{array}$ & $\begin{array}{c}\text { Etanol } \\
\text { Lodo } \\
\text { hidrolisado }\end{array}$ & $\mathrm{NO}_{3}^{-}$ & $\begin{array}{c}\mathrm{DQO} / \mathrm{N}=4,5 \\
\mathrm{DQO} / \mathrm{N}=8 \mathrm{a} \\
10,5\end{array}$ \\
\hline $\begin{array}{l}\text { KATSOGIANNIS } \\
\text { et al. (2003) }\end{array}$ & RBS & acetato & $\mathrm{NO}_{2}^{-}$ & $\mathrm{C} / \mathrm{N}=3$ \\
\hline $\begin{array}{l}\text { CARRERA et al. } \\
(2004)\end{array}$ & $\begin{array}{c}\text { Sistema } \\
\text { biológico de } \\
\text { remoção de } \\
\text { nutrientes }\end{array}$ & etanol & & $\mathrm{DQO} / \mathrm{N}=7$ \\
\hline GEE e KIM (2004) & RBS & metanol & $\mathrm{NO}_{3}^{-}$ & $\mathrm{DQO} / \mathrm{N}=1,56$ \\
\hline
\end{tabular}

\subsection{3 - Novos processos biológicos para remoção de nitrogênio}

A remoção biológica de nitrogênio tem incorporado novos processos microbianos: SHARON, ANAMMOX, desamonificação, OLAND e nitrificação/desnitrificação por metanotróficas. Isso foi possível devido aos novos conceitos como desnitrificação aeróbia e nitrificação heterotrófica, também chamado de nitrificação e desnitrificação simultâneas (NDS), oxidação anaeróbia de N-amoniacal ou desnitrificação por nitrificantes autotróficas.

O princípio do SHARON (single reactor high activity ammonia removal over nitrite) é de nitrificação via nitrito (diminuindo-se o tempo de residência celular e 
aumentando-se a temperatura, para favorecer o crescimento de Nitrosomonas), economizando energia e doadores de energia, desde que o processo de nitrificação completa seja bloqueado de maneira a formar nitrito como produto final. O processo SHARON é reproduzido em reator de mistura perfeita, sem retenção de lodo, e é mais adequado para efluentes contendo concentrações do íon amônio maiores que $500 \mathrm{mg}$ N/L. O nitrito formado no SHARON, combinado com o íon amônio, pode produzir $\mathrm{N}_{2}$ através do ANAMMOX (anaerobic ammonium oxidation).

Essa reação requer nitritação prévia, pois há necessidade de nitrito $(\mathrm{NO} \overline{2})$ como doador de elétrons, mas esta situação pode resultar em competição entre bactérias autotróficas ANAMMOX e bactérias desnitrificantes heterotróficas no processo de remoção de $\mathrm{N}$, tratando resíduo carbonáceo.

O ANAMMOX é mediado por bactérias da ordem Planctomycetales, duas das quais são chamadas provisoriamente de Brocadia anammoxidans e Kuenenia stuttgartiensis (SCHMIDT et al., 2003). A estequiometria para reação ANAMMOX foi representada pelas seguintes reações (STROUS et al., 1997):

$\mathrm{NH} 4+1,32 \mathrm{NO} 2+0,066 \mathrm{HCO} 3+0,13 \mathrm{H} \rightarrow 1,02 \mathrm{~N} 2+0,26 \mathrm{NO} 3+0,066 \mathrm{CH} 2 \mathrm{O} 5,5 \mathrm{~N} 0,15$ $+2,03 \mathrm{H} 2 \mathrm{O}$

O processo de desamonificação "aeróbia” baseia-se na conversão do íon amônio em $\mathrm{N}_{2}$, sem o uso de doador externo de elétrons e com rigoroso controle do suprimento de oxigênio.

O OLAND, similarmente ao ANAMMOX, se fundamenta, principalmente, na oxidação do íon amônio, acoplada com a redução de nitrito, com economia de 62,5 \% em $\mathrm{O}_{2}$ e $100 \%$ em doadores de elétrons, sendo as reações catalisadas por culturas enriquecidas de bactérias nitrificantes autotróficas. (VERSTRAETE e PHILIPS, 1998).

\section{2 - Reator em batelada seqüencial}

O processo biológico de nitrificação e desnitrificação pode ser realizado em reator em batelada seqüencial (RBS), cujos ciclos seqüenciais e intermitentes de aeração e não aeração permite remoção de $\mathrm{N}$ e de $\mathrm{P}$.

O RBS é um reator operado nas etapas seqüenciais de enchimento, reação, sedimentação dos sólidos, retirada do sobrenadante e reator ocioso (ou em repouso), 
todas ocorrendo no mesmo tanque (METCALF e EDDY, 1991; EPA, 1999).

A massa biológica permanece dentro do reator durante todas as etapas, eliminando dessa forma a necessidade de decantadores separados (VON SPERLING et al., 2001).

Processos biológicos baseados em bateladas de enchimento e retirada não são recentes. De acordo com EPA (1999) e Irvine et al. (1979), entre 1914 e 1920, muitos desses sistemas em batelada em escala real estavam em operação e foram abandonados por sua aparente complexidade com relação a equipamentos e operação. A partir de 1950, o interesse por essa tecnologia foi renovado com o desenvolvimento de novos equipamentos e tecnologia: melhoria nos sistemas de aeração e controle de automação. Isto permitiu que os reatores em batelada competissem com sucesso com os sistemas convencionais de lodos ativados.

ARORA et al. (1985) sugeriram estratégias diferentes de operação com a finalidade de atingir diferentes objetivos no que se refere à qualidade desejada do efluente (mas sem distinguir faixas de concentração). A nitrificação pode ser atingida por meio do aumento do tempo de duração de reação, ou pelo aumento da duração da fase de enchimento, enquanto desnitrificação pode ser efetuada pelo aumento da duração da fase de sedimentação e descarte, desde que a concentração de OD seja zero.

A remoção de fósforo ocorrerá na ausência de nitrogênio oxidado e de OD durante a etapa de enchimento, quando a biomassa libera compostos de fósforo, posteriormente assimilados em excesso durante o período de reação (fase aerada) (ARORA et al., 1985). Sob condições anaeróbias, os organismos acumuladores de fósforo estocam (por assimilação) produtos da fermentação e na etapa aeróbia, os microrganismos utilizam esses substratos estocados e consomem fósforo solúvel em quantidades maiores do que o necessário para seu funcionamento. Segundo Surampalli et al. (1997), esse consumo de fósforo é maximizado em concentrações de OD de $2 \mathrm{mg}$ $\mathrm{O}_{2} /$ L. Portanto, para remoção biológica de fósforo ocorrer, é necessário uma etapa anaeróbia inicial para produção de produtos fermentados. Por isso, para ocorrer remoção de nitrogênio, é necessário que a desnitrificação ocorra antes da remoção de fósforo.

A nitrificação pode ser atingida com tempo de retenção de sólidos (TRS) suficientemente longo ( 5 a 10 dias ou mais) para assegurar o crescimento de organismos nitrificantes, em reator com concentração de OD de $2 \mathrm{mg} \mathrm{O}_{2} / \mathrm{L}$. Para a desnitrificação, é necessário que o líquido permaneça no RBS, na presença de nitratos, mas na ausência 
de OD (ARORA et al., 1985). As principais características de cada etapa do ciclo são apresentadas no Quadro 3.3.

Quadro 3.3 - Etapas do ciclo de operação de um reator aeróbio em batelada.

\begin{tabular}{|l|l|}
\hline Etapa & Descrição \\
\hline Enchimento & $\begin{array}{l}\text { Consiste na adição da água residuária para a atividade microbiana. } \\
\text { Pode ser estático, com mistura ou reação. } \\
\text { O enchimento estático envolve a introdução do esgoto sem mistura } \\
\text { ou aeração. É mais comum em estações que objetivam a remoção de } \\
\text { nutrientes. Nessa aplicação, o enchimento estático é acompanhado } \\
\text { de enchimento com mistura, expondo os microrganismos a } \\
\text { quantidades suficientes de substrato e, ao mesmo tempo, } \\
\text { promovendo condições anóxicas ou anaeróbias. Tanto a mistura, } \\
\text { quanto a aeração, são efetuadas na etapa de enchimento com reação. } \\
\text { O sistema permite a adoção de diferentes tipos de enchimento ao } \\
\text { longo do ciclo operacional. }\end{array}$ \\
\hline Reação & $\begin{array}{l}\text { O objetivo da etapa de reação é completar as reações iniciadas } \\
\text { durante o enchimento. Pode compreender mistura, aeração ou } \\
\text { ambas. }\end{array}$ \\
\hline Sedimentação & Ocorre a separação sólido-líquido. \\
\hline Esvaziamento & Retira-se o efluente clarificado. \\
\hline Repouso & $\begin{array}{l}\text { A etapa final é denominada de repouso, sendo utilizada apenas em } \\
\text { aplicação com vários tanques.Geralmente o descarte de lodo ocorre } \\
\text { nessa etapa. }\end{array}$ \\
\hline
\end{tabular}

Fonte - $\mathrm{EPA}^{5}(1993$ apud CHERNICHARO 2001).

Durante a etapa de enchimento, pode ocorrer alguma remoção de formas oxidadas de nitrogênio (principalmente nitrito), remanescentes do ciclo anterior, caso o enchimento seja feito com aeradores desligados. Com isso, ocorre a pré-desnitrificação na presença do carbono orgânico do esgoto afluente. Após a etapa de reação aeróbia, segue-se a etapa anóxica, na qual ocorre a etapa de desnitrificação.

A duração das etapas pode ser controlada por temporizadores, nível de líquido ou pelo grau de tratamento. Um tempo de ciclo típico é de 6 a $8 \mathrm{~h}$. A etapa de reator ocioso proporciona mais uma etapa anóxica, no caso de sistema de vários tanques (SURAMPALLI et al., 1997).

A duração varia em função das variações da carga afluente, dos objetivos operacionais, do tratamento, da composição da água residuária e da biomassa no sistema (VON SPERLING et al., 2001)

$\mathrm{O}$ uso de uma segunda etapa de enchimento em RBS feito por Bortone et al. (1992), possibilitou aumento da velocidade de desnitrificação quando comparado ao

${ }^{5}$ EPA, United States Environmental Protection Agency, Cincinatti. Manual. Nitrogen control. Technology Transfer. 1993. $311 \mathrm{p}$ apud CHERNICHARO, C.A. (Org.) (2001). Pós tratamento de efluentes de reatores anaeróbios. Belo Horizonte: [s.n.]. Projeto PROSAB. 
reator controle sem segunda etapa de enchimento. $\mathrm{O}$ reator controle procedeu um único um enchimento anóxico de $51 \mathrm{em} 10 \mathrm{~min}$; enquanto no outro reator realizou-se um primeiro enchimento $(3,75 \mathrm{~L})$ anóxico (6h de duração) seguido de período aeróbio de $7 \mathrm{~h}$ e um segundo enchimento $(1,25 \mathrm{~L})$ anóxico $(4 \mathrm{~h})$ com aeróbio de $6 \mathrm{~h}$. O tempo de enchimento para ambos os períodos anóxicos foi de $10 \mathrm{~min}$.

\section{3 - Remoção biológica de nitrogênio utilizando aeração intermitente}

A operação sob aeração intermitente se refere ao modo cíclico, com período específico de aeração, seguido de período específico de não aeração. O processo incorpora uma zona não aerada que oferece muitas vantagens, tais como a melhoria de remoção de nitrogênio, economia de energia, menor produção de lodo (comparado ao sistema de lodos ativados convencional) e com pH estável devido à desnitrificação (CHEN et al., 2000). Turk e Mavinic (1989) verificaram que a mudança de condições anóxicas para aeróbias ocasiona um tempo lag que pode causar acúmulo de nitrito.

Como a etapa de oxidação de $\mathrm{N}$-amoniacal é um processo relativamente lento, NDS requer um substrato lentamente degradável de modo que seu potencial redutor esteja disponível para desnitrificação através do processo de nitrificação, ao invés de ser rapidamente oxidado a $\mathrm{CO}_{2}$ dentro dos estágios anteriores de aeração.

Gee e Kim (2004) relataram o efeito positivo e estimulante da duração dos períodos anóxicos ( 4 e $8 \mathrm{~h}$ ) sobre a atividade das bactérias nitrificantes. O tempo para completa oxidação de $\mathrm{N}$-amoniacal foi reduzido e os picos de concentração de nitrito foram menores, mostrando aumento progressivo da velocidade de oxidação de nitrito. Os autores obtiveram oxidação de $240 \mathrm{mg} \mathrm{N}-\mathrm{NH}_{4}^{+} / \mathrm{L}$ em 15 h de aeração contínua; em $10 \mathrm{~h}$ de ciclo aeróbio com $4 \mathrm{~h}$ de período anóxico; e em $7 \mathrm{~h}$ de ciclo aeróbio com $7 \mathrm{~h}$ de período anóxico.

Outra vantagem da operação sob aeração intermitente se refere ao fato de que devido à alternância de condições ambientais (anóxico e aeróbio), a microbiota do lodo, ao ajustar-se à situação, desenvolve a habilidade de tomar substrato solúvel e estocar internamente para utilização durante período de escassez (JENKINS et al., 2003). Além disso, os autores relatam que é uma forma de se evitar o crescimento indesejado de organismos filamentosos, pois estes são menos hábeis para executar esse tipo de via.

Katsogiannis et al. (2004) atribuíram a supressão da atividade das bactérias 
oxidantes de nitrito à duração curta da fase de aeração. Os autores obtiveram alta eficiência de remoção de nitrogênio (98\%) através da implantação de estratégia operacional com duração de 6 h com três ciclos aeróbios/anóxicos numa relação de 1/3 (20 $\mathrm{min} / 60 \mathrm{~min})$.

\section{4 - Nitrificação e desnitrificação simultâneas}

Nitrificação e desnitrificação simultâneas (NDS) implicam que os dois processos ocorrem no mesmo reator sob condições de operação idêntica. Como oxidação de Namoniacal é uma etapa relativamente lenta, NDS requer um substrato lentamente degradável de modo que seu potencial redutor esteja disponível para desnitrificação através do processo de oxidação de $\mathrm{N}$-amoniacal, ao invés de ser rapidamente oxidado a $\mathrm{CO}_{2}$, durante os períodos anteriores de aeração.

Munch et al. (1996) sugerem que NDS pode ser atingido pela inibição da segunda etapa da nitrificação (oxidação de nitrito a nitrato), com conseqüente economia de energia de $40 \%$.Isto seria de particular interesse na remoção de nitrogênio e fósforo de águas residuárias com relação DBO/ NTK desfavoravelmente baixa, por exemplo, $\mathrm{DBO} / \mathrm{N}-\mathrm{NH}^{+}{ }_{4}$ de 4 , de sobrenadante de digestão anaeróbia.

Pochana e Keller (1999) relataram que há três principais fatores que influenciam NDS: suprimento de carbono, concentração de OD e tamanho do floco. A adição de fonte de matéria orgânica prontamente biodegradável resultou em aumento da

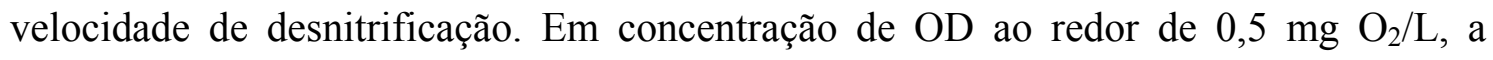
velocidade de nitrificação se iguala à velocidade de desnitrificação. Os autores concluíram que NDS é causada pela limitação da difusão de oxigênio nos flocos, gerando desse modo condições anóxicas no centro dos flocos. Desse modo, a NDS é um fenômeno físico relacionado com o tamanho do floco, que possibilita que haja uma fração anóxica no centro dos flocos.

Holman e Wareham (2005) contestam a idéia de que a concentração ideal de OD seja de $0,5 \mathrm{mg} \mathrm{O}_{2} / \mathrm{L}$ para ocorrência de NDS e que concentrações maiores que $1 \mathrm{mg}$ $\mathrm{O}_{2} / \mathrm{L}$ inibam a desnitrificação aeróbia. Os autores relataram que com a cultura de bactérias NDS estabelecida no reator, as desnitrificantes aeróbias podem continuar a reduzir nitrogênio aerobiamente por tempo limitado, desde que as concentrações de OD não excedam $1 \mathrm{mg} \mathrm{O}_{2} / \mathrm{L}$. 
Considerando-se que pode ocorrer desnitrificação aeróbia, alguns autores realizaram experimentos com nitrificação e desnitrificação simultâneas, que podem ser executadas em reator aeróbio em batelada seqüencial. Há duas hipóteses sobre os fenômenos que resultam na nitrificação e desnitrificação simultâneas: (i) de natureza física: os gradientes de concentração de OD dentro dos flocos ou biofilmes microbianos (de diâmetro de 100 a $150 \mu \mathrm{m}$ ) formam populações diferenciadas ao longo do biofilme devido às limitações difusionais: as nitrificantes ocupam zonas de altas concentrações de OD e as desnitrificantes localizam-se em regiões de concentrações mais baixas; (ii) de natureza biológica: existência de bactérias desnitrificantes aeróbias e nitrificantes heterotróficas (MUNCH et al., 1996).

Holman e Wareham (2005) relatam mais duas explicações microbiológicas: (i) supõe-se que os microrganismos responsáveis pela desnitrificação são capazes de reduzir nitrogênio por determinado tempo, mesmo quando a concentração de oxigênio dissolvido começa a aumentar, considerando que a biomassa esteja submetida a sistemas aeróbios/anóxicos; (ii) há maior variedade fisiológica de bactérias desnitrificantes. A primeira suposição é suportada pelo fato de que algumas enzimas desnitrificantes podem ser inativadas pelo oxigênio enquanto outras podem ser suprimidas e algumas enzimas podem desaparecer gradualmente.

Nitrificação e desnitrificação simultâneas são efetivas em manter o pH neutro no reator, sem adição de fonte externa de ácido/base, considerando que a faixa ótima para bactéria nitrificante está entre 7,6-8,6 enquanto que para bactéria desnitrificante é entre 7 e 8.

\section{5 - Remoção biológica de nitrogênio através da nitrificação curta}

A nitrificação completa tem sido muito estudada e essa única via tradicional tem sido revista em função dos casos de acúmulo de nitrito que têm sido relatados e que nem sempre estão relacionados com problemas operacionais como anteriormente se acreditava.

A ocorrência de acúmulo de nitrito levou à via de nitrificação curta, que consiste na inibição da atividade e crescimento de oxidantes de $\mathrm{NO}_{2}^{-}$(talvez Nitrobacter), com a conseqüente eliminação da etapa de oxidação de $\mathrm{NO}_{2}^{-}$para $\mathrm{NO}_{3}^{-}$. Esse método pode economizar fonte de energia (para aeração), fonte de carbono e alcalinidade, encurtar o 
tempo de reação tanto na nitrificação quanto na desnitrificação e reduzir excesso de lodo produzido relacionado a custos operacionais em comparação com o método tradicional de remoção de nitrogênio (ALLEMAN, 1985; TURK e MAVINIC, 1989). Esse processo também é viável no caso de tratamento de águas residuárias com baixa relação C/N (DQO/N < 3 - SCHMIDT et al., 2003).

$\mathrm{O}$ acúmulo de nitrito pode ocorrer em ampla variedade de habitats microbianos tais como solos, águas naturais e sistemas de tratamento de esgotos municipais, industriais e de resíduos agrícolas. Tais acúmulos têm sido explicados como resultados das diferenças nas velocidades de reação de organismos oxidantes de $\mathrm{N}$-amoniacal e de nitrito (ANTHONISEN et al., 1976).

Anthonisen et al. (1976) postularam que a presença de amônia livre era a principal causa para acúmulo de nitrito e a inibição da oxidação de nitrito iniciaria em concentrações de amônia livre de 0,1 a $1 \mathrm{mg} \mathrm{N}-\mathrm{NH}_{3} / \mathrm{L}$ enquanto que a inibição da oxidação de $\mathrm{N}$-amoniacal ocorreria em concentrações de 10 a $150 \mathrm{mg} \mathrm{N}-\mathrm{NH}_{3} / \mathrm{L}$. Os autores afirmaram que ácido nitroso livre $\left(\mathrm{HNO}_{2}\right)$ torna-se inibitório para oxidantes de nitrito em concentrações entre 0,22 e $2,8 \mathrm{mg} \mathrm{N}-\mathrm{HNO}_{2} / \mathrm{L}$. Outros fatores que podem afetar essas concentrações inibitórias são: adaptação, a quantidade de bactérias nitrificantes ativas e a temperatura. As concentrações nas quais a amônia livre inibiu a nitratação estão listados no Quadro 3.4.

Quadro 3.4 - Relatos de inibição da nitratação à amônia livre.

\begin{tabular}{|c|c|c|c|}
\hline Referência & $\begin{array}{c}\text { Concentração de } \\
\mathrm{N}-\mathrm{NH}_{3}\end{array}$ & Reator & Observação \\
\hline $\begin{array}{l}\text { ANTHONISEN et al. } \\
(1976)\end{array}$ & 0,1 a $1 \mathrm{mg} \mathrm{N} / \mathrm{L}$ & Lodo batelada & - \\
\hline $\begin{array}{l}\text { FORD e } \\
\text { CHURCHWELL } \\
(1980)\end{array}$ & $24 \mathrm{mg} \mathrm{N} / \mathrm{L}$ & - & 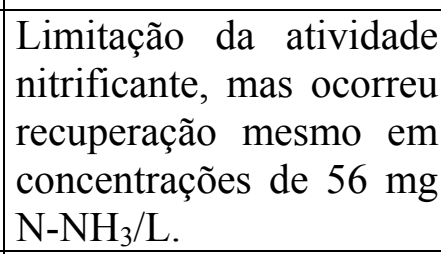 \\
\hline \begin{tabular}{|l} 
TURK e MAVINIC \\
$(1987)$
\end{tabular} & $5 \mathrm{mg} \mathrm{N} / \mathrm{L}$ & $\begin{array}{l}\text { Lodos ativados (6 } \\
\text { células em série) }\end{array}$ & $\begin{array}{l}\text { pH } 7 \text { a } 7,2 ; \text { temperatura } \\
20 \pm 2^{\circ} \mathrm{C} .\end{array}$ \\
\hline $\begin{array}{l}\text { ABELING } \\
\text { SEYFRIED (1992) }\end{array}$ & 1 a $5 \mathrm{mg} \mathrm{N} / \mathrm{L}$ & $\begin{array}{l}\text { Sistema } \\
\text { anóxico/aeróbio } \\
\text { (leito fixo) }\end{array}$ & $\begin{array}{l}\mathrm{pH} \text { controlado de } 8,3 \mathrm{a} \\
8,5 ; \text { temperatura } 20^{\circ} \mathrm{C} \\
\text { Inibiu nitratação, mas } \\
\text { não a nitritação. }\end{array}$ \\
\hline \begin{tabular}{|l} 
SURMACZ- \\
GÓRSKA et al. \\
$(1997)$
\end{tabular} & 1 a $6 \mathrm{mg} \mathrm{N} / \mathrm{L}$ & $\begin{array}{l}\text { Lodos ativados em } \\
\text { bancada }\end{array}$ & $\begin{array}{l}\mathrm{pH} \quad 8 \text {. Acúmulo } \\
\text { nitrito, sem inibição } \\
\text { oxidação } \\
\text { amoniacal. }\end{array}$ \\
\hline
\end{tabular}

Fonte - Adaptada de YOO et al. (1999) 
Fernandez-Polanco et al. (1996) mencionou que essas concentrações inibitórias são diferentes entre si porque são afetadas pelos efeitos combinados de temperatura, $\mathrm{pH}$ e concentração de $\mathrm{N}$-amoniacal. Assim, em estudo de nitrificação em filtro submerso, na ausência de inibição por amônia livre, o acúmulo de nitrito torna-se possível em baixas temperaturas, devido à menor atividade das bactérias oxidantes de nitrito. Porém, o acúmulo de nitrito será menor do que o obtido em temperaturas maiores sob efeito da inibição por amônia livre. Do mesmo modo, em $\mathrm{pH}$ baixos $(\mathrm{pH}<6)$, a atividade das bactérias oxidantes de $\mathrm{N}$-amoniacal e nitrito também diminui, mas seu quocient

e (oxidantes de $\mathrm{N}$-amoniacal/ oxidantes de nitrito) aumenta e ocorre acúmulo de nitrito, mesmo na ausência de amônia livre, relacionado à baixa alcalinidade no sistema. Quando se considerou o aumento da concentração de N-amoniacal na faixa de 50-150 mg N/L, a atividade das bactérias oxidantes de $\mathrm{N}$-amoniacal aumentou, com uma leve diminuição da atividade das bactérias oxidantes de nitrito com conseqüente aumento do quociente entre suas atividades e acúmulo de nitrito.

A amônia livre é uma base fraca, sua concentração na solução é função do valor da concentração do íon amônio, pH e temperatura. A concentração de amônia livre $\left(\mathrm{NH}_{3}\right)$ foi quantificada através de Equação dada por Anthonisen et al. (1976):

$$
\begin{gathered}
\mathrm{NH}_{3}(\mathrm{mg} / \mathrm{L})=\frac{17 \times \text { amônia total como N x } 10^{\mathrm{pH}}}{14 \mathrm{~Kb} / \mathrm{Kw}+10^{\mathrm{pH}}} \\
\begin{aligned}
\text { onde } \mathrm{Kb} / \mathrm{Kw}=\mathrm{e}^{6344 /(273+\mathrm{T})} \\
\text { sendo } \quad \mathrm{NH}_{3}=\text { concentração de } \mathrm{N} \text { como } \mathrm{NH}_{3}\left(\mathrm{mg} \mathrm{N}-\mathrm{NH}_{3} / \mathrm{L}\right) \\
\mathrm{N}=\text { concentração de amônia total }(\mathrm{mg} \mathrm{N} / \mathrm{L}) \\
\mathrm{T}=\text { temperatura }\left({ }^{\circ} \mathrm{C}\right)
\end{aligned}
\end{gathered}
$$

O balanço iônico na solução aquosa é dado pela Equação 3.6:

$$
\mathrm{NH}_{4}^{+}+\mathrm{OH}^{-} \Leftrightarrow \mathrm{NH}_{3}+\mathrm{H}_{2} \mathrm{O}
$$

Da Equação 3.6, nota-se que N-amoniacal estará em solução nas formas de íon amônio $\left(\mathrm{NH}_{4}^{+}\right)$e amônia não ionizada $\left(\mathrm{NH}_{3}\right)$. Os dois estarão em equilíbrio, que é afetado pelo $\mathrm{pH}$ da solução. Quando o pH aumenta, a concentração de amônia livre também aumentará. Em pH 8 e em temperatura de $25^{\circ} \mathrm{C}$, a proporção do íon amônio será de 93\% em relação ao $\mathrm{N}$-amoniacal total.

Quando a oxidação de N-amoniacal ocorre (Equação 3.7), há uma liberação de 
íons $\mathrm{H}^{+}$que diminuem o $\mathrm{pH}$, dependendo da capacidade tampão do sistema. $\mathrm{O}$ nitrito formado existirá em equilíbrio com ácido nitroso livre: quando o $\mathrm{pH}$ diminui, a concentração de ácido nitroso livre também aumentará, ocasionando inibição das bactérias oxidantes de nitrito.

$$
\mathrm{NH}_{4}^{+}+1,5 \mathrm{O}_{2} \Rightarrow \mathrm{H}_{2} \mathrm{O}+\mathrm{H}^{+}+\frac{\mathrm{H}^{+}+\mathrm{NO}_{2}^{-} \Leftrightarrow \mathrm{HNO}_{2}}{\qquad \begin{array}{l}
\downarrow \\
\text { Equilíbrio do ácido }
\end{array}}
$$

Com as Equações 3.6 e 3.7, Anthonisen et al. (1976) construíram o gráfico de tolerância da nitrificação, mostrado na Figura 3.1.

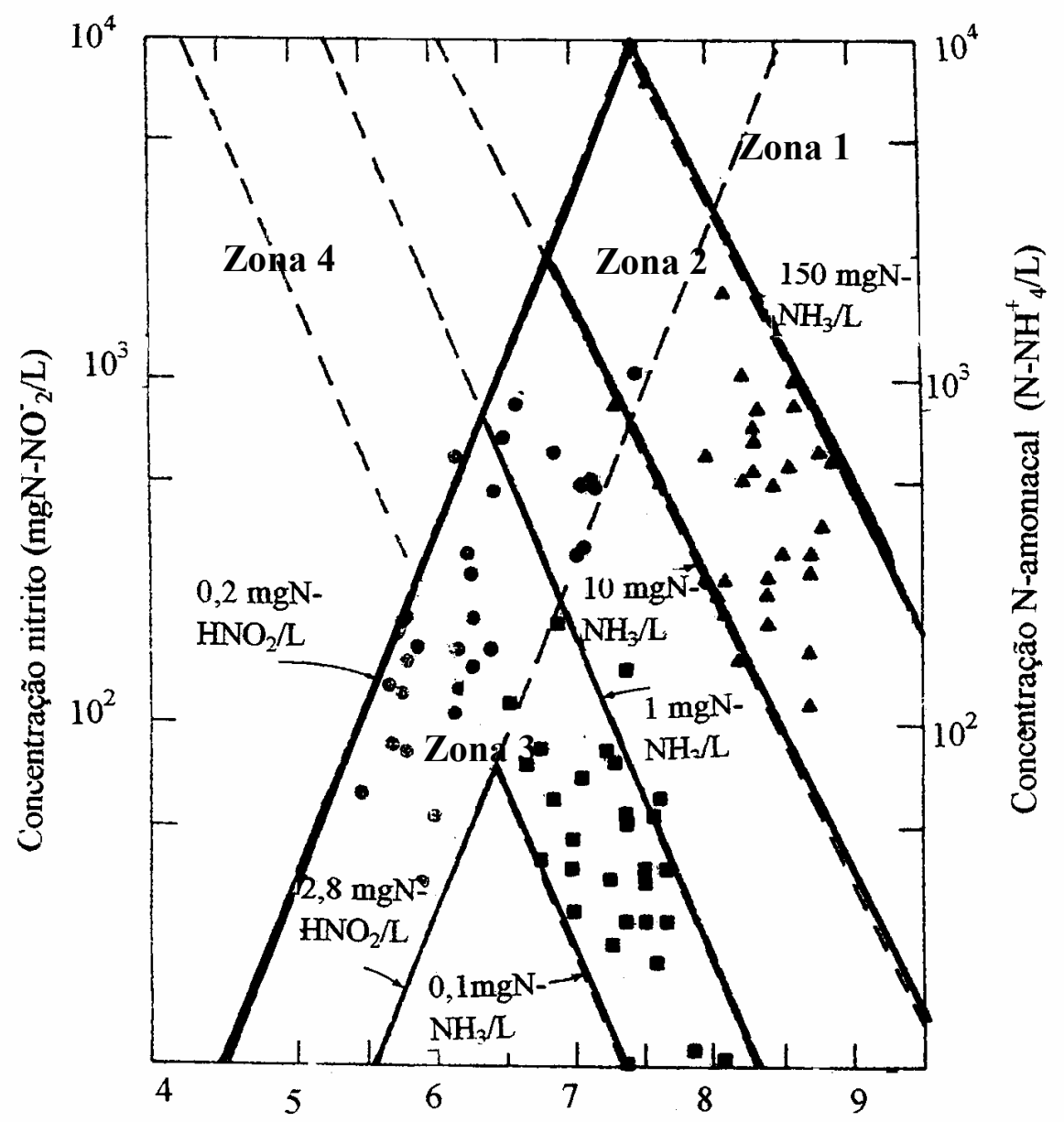

Figura 3.1 - Gráfico de tolerância à amônia livre para ocorrência de nitrificação. Fonte - ANTHONISEN et al. (1976); ÇEÇEN (1996).

A Zona 1 representa a condição de inibição total da nitrificação quando a concentração de amônia livre $\left(\mathrm{NH}_{3}\right)$ é alta (acima de $150 \mathrm{mg} \mathrm{N}-\mathrm{NH}_{3} / \mathrm{L}$ ) o suficiente para inibir tanto as bactérias oxidantes de $\mathrm{N}$-amoniacal e nitrito, impossibilitando a ocorrência de nitrificação. Na Zona 2 (10 a $\left.150 \mathrm{mg} \mathrm{N}-\mathrm{NH}_{3} / \mathrm{L}\right)$, somente as bactérias 
oxidantes de nitrito serão inibidas e pode ocorrer acúmulo de nitrito. Na Zona 3 (0,1 a 1 mg N-NH$/ 2$ ), em concentrações ainda menores de amônia livre, não haverá inibição de ambas as bactérias e ocorrerá nitrificação completa. Em baixo $\mathrm{pH}(\mathrm{pH}<5,5)$, pode ocorrer inibição da nitrificação por ácido nitroso livre $(0,2$ a 2,8 mg N-HNO$/ \mathrm{L})$, apresentado na Zona 4. A análise dos limites dessas zonas deve ser criteriosa, pois essas considerações de Anthonisen et al. (1976) foram desenvolvidas para sistemas de crescimento suspenso.

Turk e Mavinic (1989) contestaram a hipótese de que apenas a presença de amônia livre causa o acúmulo de nitrito, pois as oxidantes de nitrito podem adaptar-se a altas concentrações de amônia livre. Em outros estudos, os autores concluíram que a concentração baixa de OD também pode causar acúmulo de nitrito (concentração de OD de 0,5 $\mathrm{mg} \mathrm{O}_{2} / \mathrm{L}$ em Hanaki et al., 1990 e condições de concentração de OD de 0,5 mg $\mathrm{O}_{2} / \mathrm{L}$ e pH 7,5 em Yang e Alleman, 1992). No experimento de Yang e Alleman (1992) houve acúmulo de hidroxilamina (um intermediário na nitrificação) em sistema nitrificante em batelada com oxigênio deficiente e $\mathrm{pH}$ alto com conseqüente nitratação inibida. Em biomassa adaptada em filtros submersos, Çeçen e Gonenç (1995) relataram que concentrações de $40 \mathrm{mg} \mathrm{N}-\mathrm{NH}_{3} / \mathrm{L}$ não provocaram inibição nem da oxidação de $\mathrm{N}$ amoniacal e nem da oxidação de nitrito.

Segundo Anthonisen et al. (1976), dois processos trabalham para reduzir a inibição por amônia livre. Quando o valor de $\mathrm{pH}$ diminui o equilíbrio de $\mathrm{N}$-amoniacal ajusta-se e a concentração de amônia livre diminui. Além do mais, a concentração total de $\mathrm{N}$-amoniacal diminuirá com a oxidação de nitrito. Estas reduções tendem a aliviar a inibição da oxidação de nitrito causada por amônia livre.

Yun e Kim (2003) observaram que a concentração de amônia livre pode ser controlada pelo ajuste de $\mathrm{pH}$, estratégia de alimentação da água residuária (batelada alimentada) e características dos reatores (contínuos e plug flow). A configuração plugflow diminuiu a inibição por amônia livre, considerando-se que as concentrações diminuem ao longo desse reator. Considerando esse decréscimo de inibição, FernandezPolanco et al. (1996) utilizaram a configuração plug-flow para projetar seu biofiltro submerso.

Hanaki et al. (1990) concluíram que houve inibição da oxidação de nitrito em concentração de $\mathrm{OD}$ de $0,5 \mathrm{mg} \mathrm{O}_{2} / \mathrm{L}$ e o nitrito acumulado atingiu $60 \mathrm{mg} \mathrm{N}-\mathrm{NO}_{2}^{-} / \mathrm{L} \mathrm{em}^{-}$ tempo de retenção hidráulica (TRH) de 2 a 3,8 d. A aplicação de baixa concentração de OD duplicou o rendimento de crescimento de oxidantes de $\mathrm{N}$-amoniacal e este efeito 
positivo compensou a velocidade de oxidação por unidade de massa de célula. Por outro lado, inibiu a oxidação de nitrito, e como as oxidantes de nitrito não possuem esse sistema de compensação de redução da velocidade específica de utilização de substrato, a velocidade global de oxidação de nitrito foi significativamente reduzida. Desse modo, ocorreu acúmulo de nitrito, pois enquanto a oxidação de $\mathrm{N}$-amoniacal não foi afetada, a oxidação de nitrito foi inibida em baixas concentrações de OD.

Alleman (1985) relatou que a presença de amônia livre foi fator contribuinte para o acúmulo de nitrito juntamente com condições limitadas de oxigênio.

Osada et al. (1991) detectaram acúmulo de nitrito, em operação convencional (aeração contínua), quando a relação N/DBO foi aumentada para 0,31 , e em operação em ciclo 1:1 (aeração: não aeração), com a relação N/DBO de 0,45, afetando negativamente a eficiência de remoção de nitrogênio. A estratégia de Bortone et al. (1992) foi fazer um único descarte diário com a alimentação distribuída pelo número de ciclos e feita no início de cada fase anóxica, melhorando a distribuição de doadores de elétrons, resultando em menor concentração de formas oxidadas de nitrogênio (N-NO $\bar{x}$ ) no efluente.

Çeçen e Gönenç (1995) observaram acúmulo de nitrito em filtros aerados submersos, sendo que esse nitrito foi reduzido na desnitrificação subseqüente, sem causar efeitos inibitórios e sem diminuir a taxa de desnitrificação. Os autores concluíram que as concentrações de nitrito podem ser relacionadas a vários fatores; tais como, a concentração de amônia livre associada com alta concentração de $\mathrm{NH}_{4}{ }^{+}$no meio líquido, além da relação oxigênio/amônia. Essas relações explicam melhor porque a amônia livre não pode ser considerada como a única causa do acúmulo de nitrito. Desse modo, a insuficiência de oxigênio agiria como parâmetro limitante à completa oxidação de N-amoniacal devido à formação de hidroxilamina como produto intermediário. Concluíram experimentalmente, que para ocorrer acúmulo de nitrito, a concentração de OD no sistema deve ser cinco vezes superior à de $\mathrm{NH}_{4}^{+}$. De acordo com Hooper (1984), o mecanismo da nitritação ocorre conforme as seguintes Equações:

$$
\begin{aligned}
& 2 \mathrm{H}^{+}+\mathrm{NH}_{3}+2 \mathrm{e}^{-}+\mathrm{O}_{2} \Rightarrow \mathrm{NH}_{2} \mathrm{OH}+\mathrm{H}_{2} \mathrm{O} \\
& \mathrm{NH}_{2} \mathrm{OH}+\mathrm{H}_{2} \mathrm{O} \Rightarrow \mathrm{HNO}_{2}+4 \mathrm{e}^{-}+4 \mathrm{H}^{+} \\
& \underline{2 \mathrm{H}^{+}+0,5 \mathrm{O}_{2}} \underline{+2 \mathrm{e}^{-} \Rightarrow \mathrm{H}_{2}} \underline{\mathrm{O}} \\
& 2 \mathrm{NH}_{3}+3 \mathrm{O}_{2} \Rightarrow 2 \mathrm{HNO}_{2}+2 \mathrm{H}_{2} \mathrm{O}
\end{aligned}
$$

Baseado nesse mecanismo, hidroxilamina $\left(\mathrm{NH}_{2} \mathrm{OH}\right)$ pode acumular no sistema 
em concentrações limitadas de oxigênio (YANG e ALLEMAN, 1992):

$$
\begin{aligned}
& 4 \mathrm{H}^{+}+2 \mathrm{NH}_{3}+4 \mathrm{e}^{-}+2 \mathrm{O}_{2} \Rightarrow 2 \mathrm{NH}_{2} \mathrm{OH}+2 \mathrm{H}_{2} \mathrm{O} \\
& \underline{\mathrm{NH}_{2}} \underline{\mathrm{OH}+\mathrm{H}_{2}} \underline{\mathrm{O} \Rightarrow \mathrm{HNO}_{2}}+4 \mathrm{e}^{-}+4 \mathrm{H}^{+} \\
& 2 \mathrm{NH}_{3}+2 \mathrm{O}_{2} \Rightarrow \mathrm{NH}_{2} \mathrm{OH}+\mathrm{HNO}_{2}+\mathrm{H}_{2} \mathrm{O}
\end{aligned}
$$

$\mathrm{O}$ autor relata que esse acúmulo de hidroxilamina pode ser devido à habilidade da hidroxilamina penetrar na membrana celular das bactérias oxidantes de nitrito para exercer efeito inibitório na atividade enzimática (nitrito oxidoredutase) responsável pela oxidação de nitrito, que está localizada na membrana bacteriana.

Çeçen (1996) concluiu que além do efeito da adaptação das bactérias oxidantes de nitrito, a diminuição da concentração de nitrogênio, ocasionada por sua própria oxidação, pode tornar inviável o acúmulo de nitrito, ocorrendo nitrificação completa, mesmo em concentrações de $22 \mathrm{mg} \mathrm{N}-\mathrm{NH}_{3} / \mathrm{L}$. O autor relatou que além do valor absoluto da concentração de amônia livre, devem ser consideradas as relações oxigênio/íon amônio e oxigênio/ amônia livre, no caso de filtros submersos. Na relação $\mathrm{OD} / \mathrm{NH}_{4}^{+}>1$ não houve acúmulo de nitrito e na relação $\mathrm{OD} / \mathrm{NH}_{3}>10$ no bulk líquido, há uma diminuição do efeito da amônia livre. Porém, em sistema de crescimento suspenso relatado por Yang e Alleman (1992) com relação OD/ $\mathrm{NH}_{3}=2,1$ e pH 7,5, não ocorreu acúmulo de nitrito, enquanto que em relação OD/NH3 de 0,17 houve acúmulo de nitrito. Isso justifica que alta concentração de amônia livre não pode ser considerada como única causa de acúmulo de nitrito. Do mesmo modo, a baixa concentração de OD também não pode ser considerada como fator dominante, pois ocorreu acúmulo de nitrito em sistema com alta concentração de $\mathrm{OD}$ e pH 8 e 8,5, enquanto não houve em $\mathrm{pH} 7,0$.

Além dos fatores citados anteriormente, Hao e Chen (1994) adicionaram a presença de componentes específicos como cloreto de potássio $\left(\mathrm{KClO}_{3}\right)$ e níquel $(\mathrm{Ni})$ dentre os fatores que favorecem a presença de nitrito em altas concentrações. Os autores obtiveram elevadas concentrações de nitrito, em filtros submersos, em taxas altas de carregamento hidráulico $\left(5 \mathrm{~L} / \mathrm{d} \cdot \mathrm{cm}^{2}\right)$ e de amônio $\left(0,7 \mathrm{~kg} \mathrm{~N} / \mathrm{d} . \mathrm{m}^{2}\right), \mathrm{pH}=8,8$ e baixa relação alcalinidade $/ \mathrm{N}$-amoniacal $\left(6 \mathrm{mg} \mathrm{CaCO}_{3} / \mathrm{mg} \mathrm{NH}_{4}\right)$, devido ao efeito inibitório da hidroxilamina (2,5 a $5 \mathrm{mg}$ N/L) sobre as Nitrosomonas. Stuven et al. (1992) relataram inibição total de oxidantes de nitrito em concentrações de $1 \mathrm{mg} \mathrm{N}-\mathrm{NH}_{2} \mathrm{OH} / \mathrm{L}$.

Munch et al. (1996) obtiveram elevada concentração de nitrito (máxima de 15 mg N-NO- ${ }_{2}^{-} / \mathrm{L}$ ) e inibição da atividade das Nitrobacter, tendo concluído que o acúmulo 
de nitrito deveu-se às baixas concentrações de OD e possível inibição das Nitrobacter devido às altas concentrações de amônia livre ou níveis elevados de $\mathrm{pH}$, na manta de lodo, durante a seqüência de enchimento sem mistura. Esses dados concordam com o relatado por Wiesman (1994) de que o fato da constante de afinidade para bactéria oxidante de nitrito $(1,1)$ ser o triplo do valor para oxigênio da bactéria oxidante de Namoniacal $(0,3)$, a concentração baixa de OD reduziria a atividade das bactérias oxidantes de nitrito, produzindo acúmulo de nitrito.

Yoo et al. (1999) citaram os fatores que afetam o acúmulo transiente de nitrito (nitritação): concentração de amônia livre, concentração de hidroxilamina livre, pH, temperatura, concentração de OD. Quanto à concentração de amônia livre, que inibe a nitratação, há muitas contradições em literatura, com valores variando de 1 a 150 mg N$\mathrm{NH}_{3} /$ L. Muitas vezes, o valor depende das condições de adaptação da biomassa. Em relação à temperatura, a inibição de Nitrobacter por amônia livre não ocorre na faixa de 10 a $20{ }^{\circ} \mathrm{C}$, mas o efeito inibitório torna-se preponderante a partir de $25^{\circ} \mathrm{C}$. Os autores consideraram que houve um tempo de retardo da nitratação, isto é, as velocidades de nitritação atrasaram as velocidades de nitratação, resultando em temporário, mas significativo acúmulo de nitrito, que poderia durar várias horas dentro da célula aeróbia. A duração do tempo de aeração pareceu ser inversamente proporcional ao grau de acúmulo de nitrito. Essa duração deve ser longa o suficiente para a remoção eficiente de DQO, nitrificação e desnitrificação, mas curta o suficiente para evitar a adaptação das bactérias oxidantes de nitrito ao ambiente aeróbio. Quanto à concentração de $\mathrm{OD}$, de acordo com os autores, a nitritação efetiva pode ser atingida por suprimento de menor quantidade de ar durante a nitrificação, em relação OD/amônia livre menor que 5. Os autores supuseram que a hidroxilamina inibe a nitratação das Nitrobacter e que pode acumular-se sob alta concentração $\mathrm{N}-\mathrm{NH}_{3} / \mathrm{N}-\mathrm{NH}^{+}{ }_{4}$, OD insuficiente e alto $\mathrm{pH}$. Fux et al. (2003) relataram que ocorreu inibição total da oxidação de nitrito em $1 \mathrm{mg} / \mathrm{L}$ de hidroxilamina.

Villaverde et al. (2000), operaram RBS com águas residuárias de indústria de amido de batata. Os autores notaram que houve inibição seletiva das bactérias que oxidam nitrito e postularam duas possíveis explicações: (i) inibição seletiva pela amônia livre, em concentrações de $30 \mathrm{mg} \mathrm{N}-\mathrm{NH}_{3} / \mathrm{L}$; (ii) interação entre bactérias oxidantes de $\mathrm{N}$-amoniacal e redutoras de nitrito, com a maior parte do nitrito gerado sendo imediatamente reduzido a nitrogênio molecular. Obtiveram eficiência de remoção via nitrito de $79 \%$. 
Esses autores sugeriram aeração de ciclo curto (para evitar esse acúmulo), que deve ser controlado no tempo através da concentração de oxigênio e potencial redox, para controlar o suprimento de ar no sistema. Alleman (1985) obtiveram acúmulo de nitrito em tempos mais curtos de aeração (3h), enquanto que nitrato predominou em reatores RBS nitrificantes em períodos de 5 e $9 \mathrm{~h}$ de aeração.

Bernet et al. (2000), operando RBS anaeróbio seguido de aeróbio no tratamento de águas residuárias de suinocultura, obtiveram nitrito como principal produto $(97 \%)$, que, ao ser recirculado para o reator anaeróbio, foi eliminado durante os 20 min de enchimento. Segundo os autores, isso ocorreu devido à insuficiência de OD e à baixa afinidade por oxigênio das bactérias oxidantes de nitrito comparadas às oxidantes de $\mathrm{N}$ amoniacal, além da possível inibição pela amônia livre.

Bae et al. (2002) estudaram o acúmulo de nitrito em reatores nitrificantes em batelada com biomassa mista (suspensa e imobilizada) com variação do $\mathrm{pH}$, OD e temperatura. Neste experimento, o acúmulo de nitrito foi afetado sensivelmente pelo $\mathrm{pH}$ e temperatura, com obtenção de maiores valores em condições de $\mathrm{pH} 8$ a 9, temperatura ao redor de $30^{\circ} \mathrm{C}$ e $\mathrm{OD}$ de $1,5 \mathrm{mg} \mathrm{O}_{2} / \mathrm{L}$. A amônia livre foi inibitória à oxidação de nitrito em concentrações de $4 \mathrm{mg} \mathrm{N}-\mathrm{NH}_{3} / \mathrm{L}$. Os autores concluíram que o acúmulo de nitrito foi afetado pela concentração de amônia livre e valor de $k_{a}$ (velocidade de oxidação de amônia) e que o acúmulo de nitrito aumentou com o aumento da relação $\mathrm{k}_{\mathrm{a}} / \mathrm{k}_{\mathrm{n}}\left(\mathrm{k}_{\mathrm{n}}=\right.$ velocidade de oxidação de nitrito). $\mathrm{O}$ maior acúmulo de nitrito ocorreu em condições de $\mathrm{pH} 8$, OD de $1,5 \mathrm{mg} \mathrm{O}_{2} / \mathrm{L}$ e $\mathrm{T}=30^{\circ} \mathrm{C}$, com concentração inicial de $\mathrm{N}$ amoniacal de $50 \mathrm{mg} / \mathrm{L}$, com eficiência de remoção de nitrogênio via nitrito de $77 \%$.

Gee e Kim (2004) obtiveram acúmulo de nitrito em RBS tratando sobrenadante de digestor anaeróbio de lodo (concentração de $650 \mathrm{mg} \mathrm{N}-\mathrm{NH}^{+}{ }_{4} / \mathrm{L}$ ) com concentração de $\mathrm{OD}$ de $4 \mathrm{mg} \mathrm{O}_{2} / \mathrm{L}$, com $\mathrm{pH}$ controlado em 7,5 a 8,5 e temperatura de $24 \pm 1^{\circ} \mathrm{C}$. O ciclo aeróbio de $15 \mathrm{~h}$ seguido de $9 \mathrm{~h}$ de anoxia resultou em $80 \%$ das formas oxidadas.

Gil e Choi (2004) relataram que o desenvolvimento da nitritação em concentrações de $\mathrm{OD}$ de 2 a $4 \mathrm{mg} \mathrm{O}_{2} / \mathrm{L}$ esteve relacionado à disponibilidade de alcalinidade e TRS, isto é, quanto maior o TRS, maiores as taxas de nitritação.

Katsogiannis et al. (2004) obtiveram remoção de nitrogênio via nitrito em RBS, tratando água residuária sintética com concentração de $50 \mathrm{mg} \mathrm{N}-\mathrm{NH}^{+}{ }_{4} / \mathrm{L}$ e $150 \mathrm{mg}$ DQO/L, com acetato como fonte de carbono. A alta eficiência de remoção de nitrogênio 
(98\%) foi obtida com a utilização de estratégia operacional com duração de $6 \mathrm{~h}$ com três ciclos aeróbios/anóxicos numa relação de 1/3 (20 min/ $60 \mathrm{~min}$ ). Os autores atribuíram a supressão da atividade das bactérias oxidantes de nitrito à duração curta da fase de aeração.

No Quadro 3.5, estão listadas algumas referências bibliográficas referentes à ocorrência de acúmulo de nitrito. 
Quadro 3.5 - Causas e ocorrência de acúmulo de nitrito e remoção de nitrogênio via nitrito em reatores alimentados com diferentes substratos.

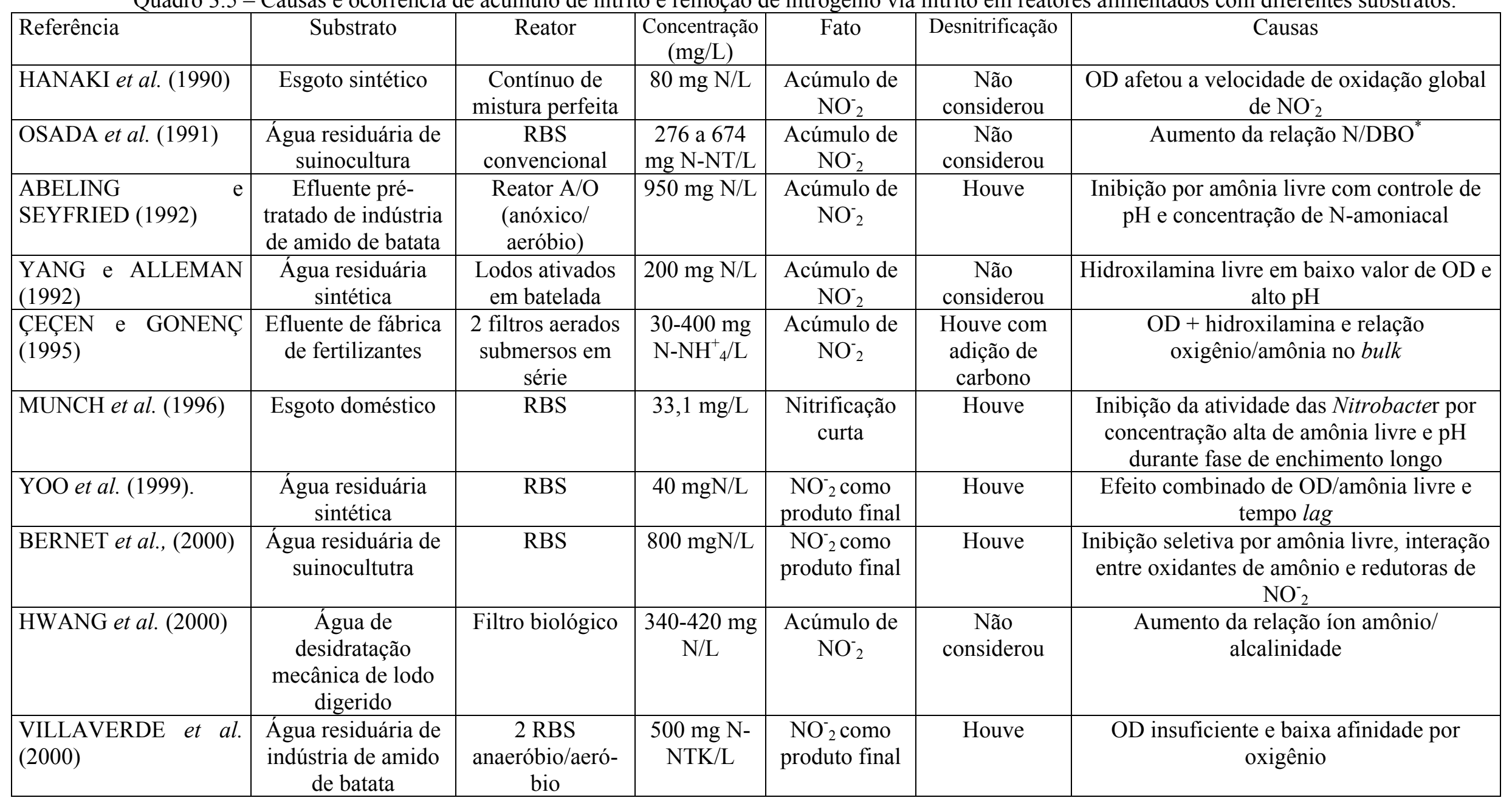


Quadro 3.5 - Causas e ocorrência de acúmulo de nitrito e remoção de nitrogênio via nitrito em reatores alimentados com diferentes substratos.

\begin{tabular}{|c|c|c|c|c|c|c|}
\hline Referência & Substrato & Reator & $\begin{array}{l}\text { Concentraçã } \\
\mathrm{o}(\mathrm{mg} / \mathrm{L})\end{array}$ & Fato & Desnitrificação & Causas \\
\hline $\begin{array}{l}\text { KATSOGIANNIS et } \\
\text { al. (2003) }\end{array}$ & $\begin{array}{|ll|}\begin{array}{l}\text { Água } \\
\text { sintética }\end{array} & \text { residuária } \\
\end{array}$ & RBS & $\begin{array}{lll}50 & \mathrm{mg} & \mathrm{N}- \\
\mathrm{NH}^{+}{ }_{4} / \mathrm{L} & \\
\end{array}$ & \begin{tabular}{|l|}
$\mathrm{NO}_{2}^{-} \quad$ como \\
produto final
\end{tabular} & Houve & Duração curta da fase aeróbia \\
\hline KIM et al. (2003) & $\begin{array}{|ll|}\begin{array}{l}\text { Água } \\
\text { sintética }\end{array} & \text { residuária } \\
\end{array}$ & $\begin{array}{l}\text { Reator de } \\
\text { biofilme airlift }\end{array}$ & $\begin{array}{l}300-750 \mathrm{mg} \\
\mathrm{N}-\mathrm{NH}^{+} / \mathrm{L}\end{array}$ & $\begin{array}{l}\text { Acúmulo de } \\
\mathrm{NO}_{2}^{-}\end{array}$ & Não considerou & \begin{tabular}{|lllll}
$\begin{array}{l}\text { Inibição seletiva por } \\
\text { limitação de ODônia }\end{array}$ & livre e & \\
\end{tabular} \\
\hline RUIZ et al. (2003) & $\begin{array}{l}\text { Água residuária } \\
\text { sintética industrial }\end{array}$ & $\begin{array}{l}\text { Sistema de } \\
\text { Lodos ativados }\end{array}$ & \begin{tabular}{|l|}
$610 \quad \mathrm{mg} / \mathrm{L}$ \\
$\mathrm{N}^{-\mathrm{NH}^{+}}{ }_{4}$
\end{tabular} & \begin{tabular}{|l|} 
Acúmulo de \\
$\mathrm{NO}_{2}^{-}$
\end{tabular} & Não considerou & OD baixo \\
\hline GEE e KIM (2004) & $\begin{array}{l}\text { Sobrenadante de } \\
\text { digestor anaeróbio }\end{array}$ & RBS & $\begin{array}{l}250 \mathrm{mg} \mathrm{N}- \\
\mathrm{NH}_{4}^{+} / \mathrm{L}\end{array}$ & \begin{tabular}{|l|} 
Acúmulo de \\
$\mathrm{NO}_{2}^{-}$
\end{tabular} & Houve & \\
\hline GIL e CHOI (2004) & $\begin{array}{l}\text { Água residuária de } \\
\text { ETA }\end{array}$ & Reator aeróbio & $\begin{array}{|lrr|}135 & \text { a } & 552 \\
\mathrm{mg} & & \mathrm{N}- \\
\mathrm{NH}^{+}{ }_{4} / \mathrm{L} & \\
\end{array}$ & $\begin{array}{l}\mathrm{NO}_{2}^{-} \text {como } \\
\text { produto final }\end{array}$ & Não considerou & Disponibilidade de alcalinidade e TRS \\
\hline
\end{tabular}

RBS= reator operado em batelada seqüencial; $\mathrm{DBO}=$ demanda bioquímica de oxigênio. $\mathrm{k}_{\mathrm{a}}=$ evelocidade de oxidação de amônio e kn =velocidade de oxidação de nitrito. ETA= Estação de Tratamento de Água. N/DBO* nesse caso, os autores consideraram essa relação, não discriminando qual forma de nitrogênio. 
Desnitrificação via nitrito pode trazer vantagens como economia de aceptor de elétrons $(25 \%)$ e de doador de elétrons $(40 \%)$, maior velocidade de desnitrificação (TURK e MAVINIC, 1987, 1989; ABELING e SEYFRIED, 1992). De um ponto de vista bioquímico, nitrito parece ser o aceptor de elétrons preferido, pois a nitrito redutase (enzima envolvida) está localizada mais próxima ao ambiente (espaço periplásmico) do que a nitrato redutase (citoplasmática), o que significa que o nitrito oferece menos resistência ao transporte (CHUNG e BAE, 2002).

Como pode ser observado nos vários resultados do Quadro 3.6, as velocidades de desnitrificação via nitrito são bem superiores quando comparados aos das velocidades de desnitrificação via nitrato.

Quadro 3.6 - Comparação entre velocidades de desnitrificação

\begin{tabular}{|c|c|c|c|c|}
\hline Referência & $\begin{array}{l}\text { Fonte de } \\
\text { carbono }\end{array}$ & $\begin{array}{c}\mathrm{rNO}_{2}^{-} \\
\left(\mathrm{mg} \mathrm{N}^{-} \mathrm{NO}_{2}^{-} / \mathrm{mg}\right. \\
\text { SSV.d) }\end{array}$ & $\begin{array}{c}\mathrm{rNO}_{3}^{-} \\
\left(\mathrm{mg} \mathrm{N}-\mathrm{NO}_{3}^{-} / \mathrm{mg}\right. \\
\text { SSV.d) }\end{array}$ & $\begin{array}{l}\mathrm{N}-\mathrm{NO}_{2}^{-} / \\
\mathrm{N}-\mathrm{NO}_{3}^{-}\end{array}$ \\
\hline $\begin{array}{l}\text { ABELING e } \\
\text { SEYFRIED (1992) }\end{array}$ & $\begin{array}{l}\text { Ácido } \\
\text { acético }\end{array}$ & 0,17 & 0,12 & 1,39 \\
\hline $\begin{array}{l}\text { BECCARI }{ }^{6} \text { et al. } \\
(1983)\end{array}$ & & 0,52 & 0,32 & 1,6 \\
\hline $\begin{array}{l}\text { TURK e MAVINIC } \\
\text { (1987) }\end{array}$ & $\begin{array}{l}\text { Acetato de } \\
\text { sódio }\end{array}$ & 1,17 & 0,73 & 1,64 \\
\hline CHUNG e BAE (2002) & Glicose & 0,76 a 1,59 & 0,29 a 0,37 & 2,6 a 4,3 \\
\hline
\end{tabular}

Fonte - CHUNG e BAE (2002).

$\mathrm{rNO}_{2}^{-}=$velocidade de desnitrificação via nitrito, $\mathrm{rNO}_{3}^{-}=$velocidade de desnitrificação via nitrato

Chung e Bae (2002) relataram uma diferença maior entre as velocidades de desnitrificação, considerando-se que houve uma graduação adaptação das células ao ambiente redutor de nitrito, proporcionando uma maior velocidade de desnitrificação via nitrito.

Então, para se atingir efetiva nitrificação/desnitrificação via nitrito, é necessário:

(i) usar processo simultâneo e/ou alternado de nitrificação e desnitrificação em um mesmo reator;

(ii) manter baixas concentrações de OD durante a aeração;

\footnotetext{
${ }^{6}$ BECCARI, M.; PASSION, R.; RAMADORI, R.; TANDOI, V. (1983). Kinetics of dissimilatory nitrae and nitrite reduction in suspended growth culture. JWPCF, Alexandria, v.55, p.58-64 apud ABELING, U.; SEYFRIED, C.F. (1992). Anaerobic-aerobic treatment of high-strength ammonium wastewater. nitrogen removal via nitrite. Water Science Technology, Oxford, v.26, n.5-6, p.1007-15.
} 
(iii) manter organismos em contato com água residuária afluente em condições de suprimento de oxigênio deficiente, para induzir contato com altas concentrações de amônia livre ou hidroxilamina livre;

(iv) elevar $\mathrm{pH}$;

(v) adicionar hidroxilamina ao reator;

(vi) manter a temperatura do reator próxima a $25^{\circ} \mathrm{C}$.

De acordo com Van Loosdrecht e Jetten (1998), há três estratégias para execução de nitrificação curta (via nitrito):

1) promover a mudança no $\mathrm{pH}$, pois este interfere nas concentrações de amônia e ácido nitroso livres, inibindo as Nitrobacter (mas alguns autores notaram que após algum tempo pode ocorrer a adaptação desses microrganismos e a nitrificação completa é restaurada);

2) provocar o "arraste" das bactérias oxidantes de nitrito baseando-se na velocidade de crescimento desses organismos (em temperaturas $>15^{\circ} \mathrm{C}$, as bactérias oxidantes de íon amônio têm maior velocidade de crescimento que as oxidantes de nitrito), e manejar cuidadosamente a idade do lodo (o SHARON é baseado nessa estratégia);

3) provocar a competição por oxigênio, uma vez que a menor afinidade por oxigênio das bactérias oxidantes de nitrito e a desnitrificação do nitrito diminuem e restringem o crescimento das bactérias oxidantes de nitrito (esse objetivo pode ser atingido criando-se condições anóxicas no interior dos flocos ou pela alternância constante das condições aeróbias e anóxicas).

Acúmulo de nitrito pode ser obtido pelo desequilíbrio no número ou atividade entre bactérias oxidantes de $\mathrm{N}$-amoniacal e oxidantes de nitrito. Segundo Kim et al. (2003), o desequilíbrio ocorre quando as bactérias oxidantes de $\mathrm{N}$-amoniacal competem com as bactérias oxidantes de nitrito em sistema misto de nitrificação. Diferenças nas atividades podem ser impostas, por exemplo, por inibição da atividade das bactérias oxidantes de nitrito à amônia livre e limitação de oxigênio dissolvido para a bactéria nitrificante (GARRIDO et al., 1997; TURK e MAVINIC, 1989). Essa inibição seletiva por amônia livre geralmente ocorrer em concentrações de amônia livre de 0,1 a $1 \mathrm{mg}$ N$\mathrm{NH}_{3} / \mathrm{L}$ (ANTHONISEN et al, 1976). Concentração baixa de OD também limitam a oxidação de nitrito, considerando-se que o coeficiente de saturação de oxigênio $\left(\mathrm{k}_{\mathrm{s}}\right)$ da oxidação de amônia e de da oxidação de nitrito são 0,3 e $1,1 \mathrm{mg} \mathrm{O}_{2} / \mathrm{L}$, respectivamente (WIESMAN,1994). 


\section{6 - Estratégias de controle - potencial redox e pH}

Vários autores fazem uso de parâmetros como o potencial redox e pH para determinar o final dos períodos anóxicos e o início dos períodos aeróbios em reatores aeróbios em batelada seqüencial, com economia de oxigênio e evitando a anaerobiose. Segundo Hao e Huang (1996), a anaerobiose exerce efeito negativo nas características do lodo. Assim, a exposição regular e freqüente da cultura microbiana à anaerobiose pode mudá-la de desnitrificantes verdadeiras para anaeróbias facultativas, havendo casos em que a estratégia provocou o acúmulo de nitrito no sistema. Esses autores demonstraram que $\mathrm{pH}$ pode definir o fim da nitrificação (ammonia valley) no ciclo aeróbio e o fim da respiração anóxica (nitrate apex) no período anóxico, colaborando para controle do processo.

Nos reatores biológicos, prótons e íons hidroxila são trocados e o potencial redox das espécies iônicas também pode mudar. Durante o período anóxico, pH aumenta devido aos íons hidroxila que podem mascarar o impacto da produção de $\mathrm{CO}_{2}$. Por apresentarem essas características, o potencial redox e o pH são parâmetros mais amplamente usados para monitoramento on line e para controle dos processos de lodos ativados, além da facilidade de uso e baixo custo dos equipamentos e sensores (eletrodos) (SPAGNI et al., 2001; LI e BISHOP, 2002).

Muitas reações enzimáticas são reações de oxidação e redução e a habilidade de um microrganismo de executar essas reações depende do estado de oxidação-redução do ambiente. Em uma solução, a proporção de componentes oxidados para reduzidos constitui o denominado potencial oxidação-redução ou potencial redox $\left(\mathrm{E}_{\mathrm{h}}\right)$. Valores positivos de $E_{h}$ favorecem oxidação, por outro lado, valores negativos favorecem redução. O potencial redox é influenciado pela presença ou ausência de oxigênio molecular. Ambientes em equilíbrio com oxigênio atmosférico apresentam valores de $\mathrm{E}_{\mathrm{h}} \cong+800 \mathrm{mV}$; enquanto que ambientes com tensões reduzidas de oxigênio tem valores menores de potencial redox. Atividade heterotrófica mantêm seu potencial redox em valores de +400 a $500 \mathrm{mV}$ em águas naturais aeróbias. Em ecossistemas poluídos, o crescimento de microrganismos heterotróficos ocasiona baixos valores de potencial redox devido ao consumo de oxigênio para processos de decomposição. Do mesmo modo, em sedimentos ricos em matéria orgânica, encontram-se valor de potencial redox 
de $-450 \mathrm{mV}$, no qual pode ocorrer redução de sulfato e $\mathrm{CO}_{2}$ (ATLAS e BARTHA, 1987).

O potencial redox também tem a vantagem de incorporar medições mais precisas em zonas não aeradas ou com baixa concentração de OD do que a medida de oxigênio dissolvido, sendo o mais promissor para controle de automação (HOLMAN e WAREHAM, 2003). O uso de "breakpoints" de potencial redox (POR) como índice para estabelecer estratégia para controle do suprimento de oxigênio em tempo real é viável para se atingir alto grau de remoção de nitrogênio.

Pedie et al. (1992) caracterizaram perfil de potencial redox ao longo do tempo associado à operação cíclica em reator digestor de lodo. Para ciclo de aeração e não aeração, o perfil tinha várias características distintas diretamente ligadas às mudanças nas atividades químicas e biológicas do reator.

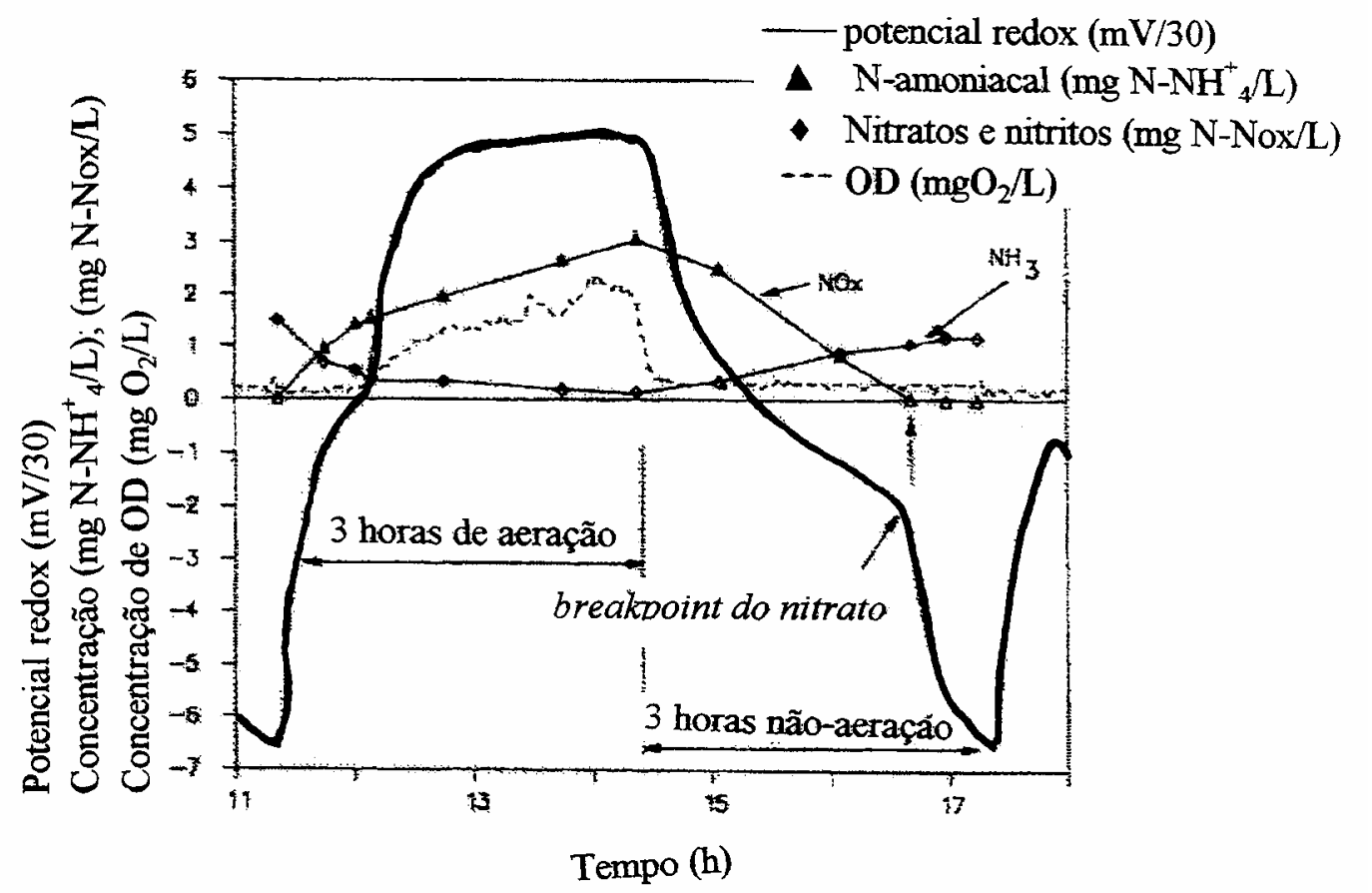

Figura 3.2 - Breakpoints no perfil de potencial redox. Fonte: WAREHAM et al. (1993)

No perfil de potencial redox, variando com o tempo, há dois pontos: breakpoint do OD e breakpoint do nitrato (nitrate knee). O breakpoint do nitrato definido por Wareham et al. (1993) está associado com o desaparecimento dos nitratos, que corresponde à transformação de processos respiratórios (que utilizam oxigênio ou nitratos) para não respiratórios (fermentativos). Na variação temporal dos valores de potencial redox corrersponde à uma súbita mudança do sinal. O breakpoint de OD corresponde ao ponto no qual a demanda de oxigênio está satisfeita (que está associada 
à concentração de $\mathrm{N}$-amoniacal gerada na fase anóxica do ciclo anterior). O breakpoint de OD corresponde à depleção de OD mensurável e refere-se a mudança abrupta na inclinação da curva de OD, resultando num pico negativo forte na curva de mudança $\mathrm{dPOR} / \mathrm{dt}$. Na Figura 3.2, corresponde ao ponto onde o valor de potencial redox é zero, no período aerado. Os autores discutem que o fim da respiração anóxica pode ser apontado tanto pelo nitrate knee ou pelo nitrate apex $(\mathrm{pH})$, pois, após esses pontos, tanto o potencial redox quanto o $\mathrm{pH}$ diminuem rapidamente, devido à geração de ácidos voláteis sob condições anaeróbias. Os autores observaram que a alimentação do reator provocou picos semelhantes aos do ponto nitrate knee, o que pode gerar confusão no caso de uma programação de pontos por computador para controlar os ciclos. No caso, optaram por efetuar a alimentação na seqüência de aeração.

Ra et al. (2000) propuseram estratégia de controle baseada na variação temporal do potencial redox ao longo do ciclo. Os autores não consideraram os valores absolutos de potencial redox, que são fortemente correlacionados com reações biológicas, o que já foi evidenciado em muitos estudos (WAREHAM et al., 1993; HOLMAN e WAREHAM, 2003). Os valores de potencial redox podem ser afetados por vários fatores, como espécies químicas, concentrações de sólidos, atividade biológica, $\mathrm{pH}$ e temperatura. Os autores estabeleceram um ponto controle, chamado de ponto de manipulação do carbono residual, estabelecendo o valor máximo do potencial redox. Atingido esse valor, o misturador e a aeração eram interrompidos, procedendo-se à alimentação. Esse ponto garantia a total remoção de $\mathrm{N}$-amoniacal, pois o mesmo sempre ocorria após o final da nitrificação.

Li e Bishop (2002) observaram que a regulação por potencial redox está mais em sintonia com o processo do que a regulação baseada em OD, pois esse somente mostra as concentrações de OD no reator durante o período aeróbio. Muitas substâncias biológicas como enzimas, vitaminas e muitos processos biológicos correlacionam-se fortemente com os valores de potencial redox. Portanto, o redox pode ser correlacionado com concentrações de DQO, OD e $\mathrm{NO}_{3}^{-} / \mathrm{NH}_{4}^{+}$.

Kishida et al. (2003) relataram que houve problemas relacionados com controle do período anóxico para relação $\mathrm{C} / \mathrm{N}$ relativamente baixa, e em alguns casos, não foram observados o nitrate knee nos perfis de potencial redox e de nitrate apex nos perfis de pH durante ciclos anóxicos.

Holman e Wareham (2003) consideraram que breakpoint do nitrato correspondeu ao ponto no qual a bactéria passou do processo de respiração (isto é, 
usando nitrato como aceptor terminal de elétrons na cadeia de transporte de elétrons) para processos menos eficientes (fermentação anaeróbia). Portanto, o breakpoint do nitrato indica o tempo em que a desnitrificação está completa, com todos os nitratos eliminados.

\section{7 - Conclusões da revisão bibliográfica}

Do que foi exposto anteriormente, pode-se concluir:

(i) ocorre acúmulo de nitrito sob certas condições, principalmente as que favorecem a inibição das bactérias que oxidam nitrito a nitrato;

(ii) o nitrito pode ser reduzido a $\mathrm{N}_{2}$ juntamente com a oxidação de $\mathrm{N}$-amoniacal na fase de desnitrificação;

(iii) a maioria dos relatos de acúmulo de nitrito relaciona-se a estudos que não tinham como finalidade o acúmulo de nitrito, mas visavam a nitrificação completa;

(iv) dentre as condições que favorecem a nitrificação via nitrito, os autores não confirmam qual é a concentração ótima de OD. Entre outros fatores pouco citados e estudados estão: a alcalinidade como fator limitante, a adição de micronutrientes como níquel e molibdênio, o efeito da relação N/DBO e o efeito da relação entre as velocidades de oxidação da amônia e de oxidação do nitrito.

$\mathrm{Na}$ Escola de Engenharia de São Carlos, a linha de pesquisa Tratamento de Águas residuárias do curso de Pós-graduação em Hidráulica e Saneamento tem sido focada em processos anaeróbios desde a década de 90. E a seqüência lógica seria o tratamento do efluente desses reatores anaeróbios tratando esgoto sintético, como o trabalho de Sousa (1996) e tratando esgoto sanitário como os trabalhos de Coletti (1997), Vieira (2000) e Marchetto (2001). A configuração de Sousa (1996) visava a nitrificação de efluente de reator anaeróbio UASB tratando esgoto sintético em reator aeróbio seqüencial em batelada seguido de desnitrificação em coluna de lodo anaeróbio. Coletti (1997) utilizou lodos ativados como pós-tratamento de efluente de reator anaeróbio (compartimentado), que resultou em remoção de $\mathrm{P}$ (da ordem de $28 \%$ ) e nitrificação de N-amoniacal. Vieira (2000) inovou com configuração de sistema misto aeróbio/anaeróbio de leito fixo em escala piloto para remoção de nitrogênio, constituído por Reator Aeróbio Radial de Leito Fixo para nitrificação de efluente proveniente de 
Reator Anaeróbio Horizontal de Leito Fixo; e, seqüencialmente, Reator Anóxico Horizontal de Leito Fixo para desnitrificação da água residuária. No experimento de Marchetto (2001), com o objetivo de remoção de nitrogênio e fósforo, foram testados reator microaerado e reator com aeração intermitente, seguidos de flotação por ar dissolvido.

Em seqüência a esses trabalhos, as pesquisas objetivaram tratamento de esgoto sanitário na remoção conjunta de carbono, nitrogênio e fósforo nos trabalhos de Torres Lozada (2000), Callado Sarmento (2001) e Mendonça (2002). Torres Lozada (2000) utilizou um sistema composto de reator anaeróbio UASB e reator aeróbio RSB, com eficiência de remoção da ordem de $80 \%$ de carbono, nitrogênio e fósforo. Callado Sarmento (2001) utilizou sistema misto anaeróbio/aeróbio, composto de três reatores operados em série, sendo dois anaeróbios e um aeróbio, com a seguinte configuração: um anaeróbio, um aeróbio e por último o anaeróbio, com a obtenção de efluente com qualidade compatível ao de tratamento terciário. O sistema piloto de Mendonça (2002), constituído por reator anaeróbio de leito expandido (Ralex) seguido por sistema de lodos ativados, demonstrou ser efetivo na remoção de DQO, nitrogênio total (65\%)e de fósforo (35\%).

Aprofundando mais os estudo relativos à remoção de nitrogênio, enfocou-se a desnitrificação como tema, em trabalhos de Santos (2003), Coelho (2005) e Médici (2005). Santos (2002) estudou a utilização de metanol, etanol e metano como fonte de carbono para a desnitrificação em frascos em batelada. $\mathrm{O}$ etanol foi o mais efetivo doador de elétrons para desnitrificação potencial de uso do metano como doador de elétrons para a desnitrificação em reator anóxico horizontal de leito fixo. Prosseguindo na utilização de metano como doador de elétrons para a desnitrificação, Médici (2005), utilizou como configuração um reator anóxico horizontal de leito fixo. Coelho (2005) empregou efluente produzido em digestor hidrolítico de lodo primário como fonte de carbono para desnitrificação em reator em bateladas seqüenciais (RBS) no tratamento de efluente de reator UASB.

Em continuidade a essas pesquisas, a remoção de nitrogênio em águas residuárias com elevadas concentrações de $\mathrm{N}$-amoniacal foi enfocada no trabalho de Castro Daniel (2005), com utilização de reator em batelada seqüencial com leito fixo. A autora obteve remoção de nitrogênio via nitrito com sucesso e com longo tempo de operação. Em paralelo, foi desenvolvida a presente pesquisa, cujo objetivo foi a aplicação de um reator operado em batelada seqüencial com biomassa suspensa e 
alimentado com água residuária sintética contendo alta concentração de $\mathrm{N}$-amoniacal em ciclos alternados anóxicos/aeróbios com o objetivo de se avaliar a capacidade de remoção de nitrogênio desse reator. 


\section{4 - MATERIAL E MÉTODOS}

A pesquisa foi desenvolvida no Laboratório de Processos Biológicos (LPB) e Laboratório de Tratamento Avançado e Reuso de Águas (LATAR), localizados no Departamento de Hidráulica e Saneamento da Escola de Engenharia de São Carlos/USP, Campus de São Carlos.

\section{1 - Descrição dos equipamentos}

Foi montado e operado um reator anóxico/aeróbio em batelada seqüencial, conforme pode ser visto na Figura 4.1.

O reator foi confeccionado em acrílico e possuía volume de $6,5 \mathrm{~L}$, tendo sido inoculado com 4,3 L de lodo aeróbio proveniente de sistema de lodos ativados da Estação de Tratamento de Esgotos de Flores da Cunha, na cidade de Rio Claro. O inóculo foi escolhido mediante estudo prévio realizado por Castro Daniel (2005), e apresentou maior variedade morfológica, melhor aspecto dos flocos e menor número de bactérias filamentosas.

O reator foi provido de impelidor mecânico para agitação do seu conteúdo e de pedra porosa no fundo do reator que promove a aeração. $\mathrm{O}$ bloco de aquisição de dados interligado a um computador controlou através de um software: os tempos de mistura do agitador, de não aeração e aeração, de operação das bombas de alimentação e descarte, além de controlar a concentração de oxigênio dissolvido no reator. O software de controle foi desenvolvido pela empresa T\& S de São Carlos, instalado em micro computador, tendo sido utilizado anteriormente por Castro Daniel (2005). Todo o sistema pode ser visto na Figura 4.2. 


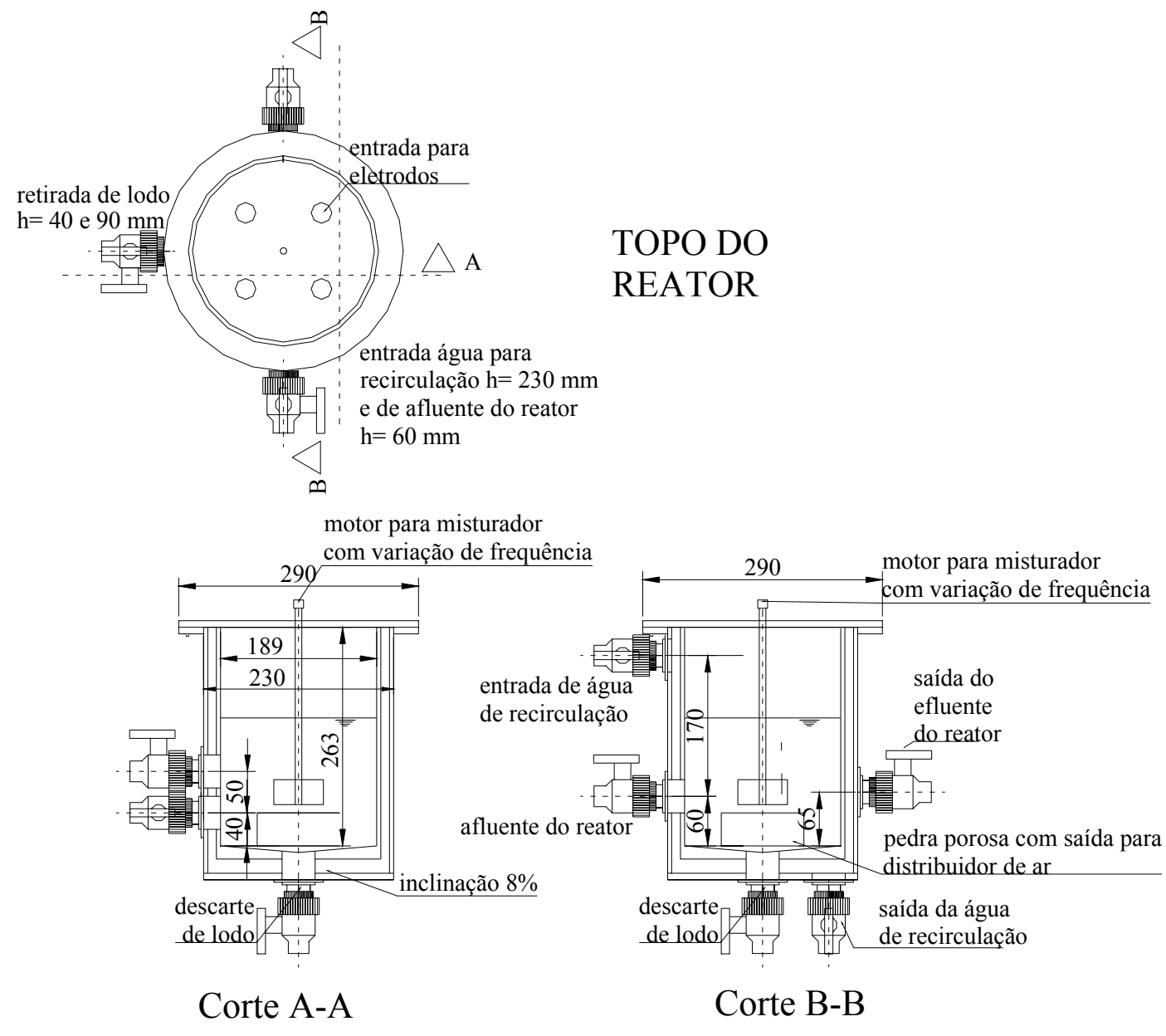

Figura 4.1 - Reator aeróbio em batelada seqüencial

O reator possuía uma camisa de acrílico e foi mantido na temperatura de $25 \pm 2^{\circ} \mathrm{C}$, através de circulação externa de água quente provinda de banho ultratermostatizado. O substrato foi mantido em geladeira e passava através de serpentina aquecida antes de ser alimentado ao reator. $\mathrm{O}$ oxigênio foi fornecido por compressor de ar e quantificado por medidor de oxigênio dissolvido (OD) marca ORION (modelo $810 \mathrm{~A}$ ), mantido em concentração média de $2 \mathrm{mg} \mathrm{O}_{2} / \mathrm{L}$ nas primeiras etapas do trabalho. 


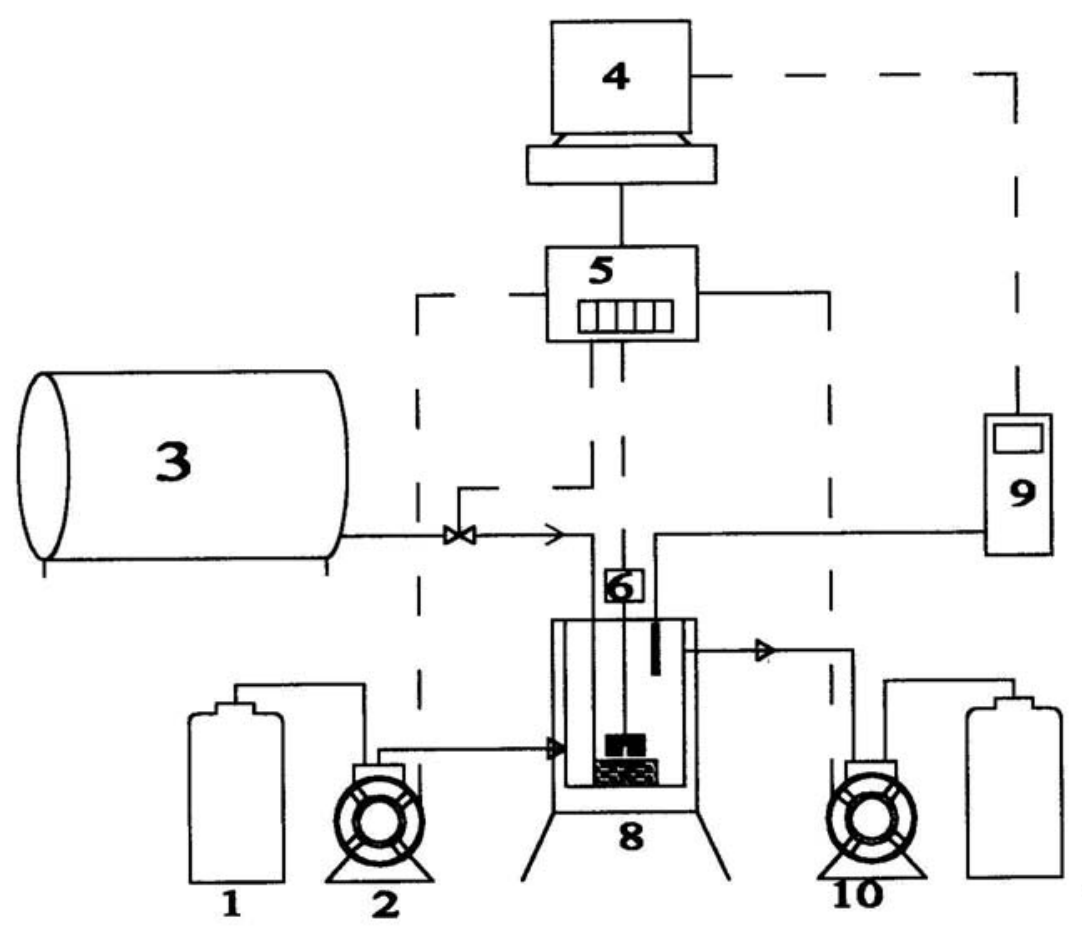

Figura 4.2 - Esquema do sistema: (1) recipiente com substrato mantido refrigerado; (2) bomba de entrada do afluente; (3) compressor de ar; (4) computador; (5) bloco de aquisição de dados; (6) agitador; (7) pedra porosa; (8) reator de acrílico de 6,5 L; medidor de OD; (10) bomba de saída.

\section{2 - Controle da concentração de oxigênio dissolvido no reator.}

A concentração de oxigênio foi controlada através de programa de computador, desenvolvido pela Empresa T\& S de São Carlos, que comanda o fechamento e abertura de entrada de ar por meio de duas válvulas solenóides. O programa permite um limite mínimo e máximo da concentração de OD, fechando a abertura de ar de uma das válvulas no valor máximo e abrindo essa mesma válvula no limite mínimo, cujas faixas de variação estão apresentadas na Tabela 4.4.

As leituras de concentração de OD eram enviadas pelo medidor OD modelo 810A via cabo RS232 à placa de aquisição de dados instalada no computador. O equipamento enviava leituras de $10 \mathrm{em} \mathrm{10s.}$

As válvulas solenóides estavam acopladas a válvulas de agulha, cujas vazões eram reguladas manualmente de modo que a concentração durante a segunda hora do período aeróbio ficasse constante na concentração de OD pretendida no reator, em quase todos os períodos aeróbios, não havendo aumento considerável até o final da 
batelada.

\section{3 - Substrato}

O substrato contendo amido como fonte de carbono orgânico foi preparado em água de abastecimento. A composição foi a seguinte $(\mathrm{mg} / \mathrm{L}):\left(\mathrm{NH}_{4}\right)_{2} \mathrm{SO}_{4}-580$, $\mathrm{NaHCO}_{3}-1700$, amido solúvel - 950, $1 \mathrm{~mL}$ de solução de sais e $1 \mathrm{~mL}$ de solução de micronutrientes, para a concentração de $125 \mathrm{mg} \mathrm{N} / \mathrm{L}$. O bicarbonato de sódio foi usado para tamponamento do meio e como fonte inorgânica de carbono .

A composição da solução de sais e micronutrientes estão apresentadas na Tabelas 4.1 e 4.2, respectivamente. As soluções foram adaptadas de Tanner (1997). A água residuária era preparada diariamente para o volume de $4 \mathrm{~L}$. As quantidades de bicarbonato de sódio, sulfato de amônio e amido adicionadas para cada concentração de $\mathrm{N}$-amoniacal estão apresentadas na Tabela 4.3, com adição de $2 \mathrm{~mL}$ de sais e $2 \mathrm{~mL}$ de micronutrientes.

Tabela 4.1 - Composição da solução de sais.

\begin{tabular}{lc}
\hline \multicolumn{1}{c}{ Composto } & $\begin{array}{c}\text { Quantidade } \\
\text { (q.s.p 1000 } \\
\mathrm{mL} \text { ) }\end{array}$ \\
\hline Sulfato de magnésio & $20 \mathrm{mg} / \mathrm{L}$ \\
Cloreto de cálcio & $4 \mathrm{mg} / \mathrm{L}$ \\
Fosfato de potássio monobásico & $10 \mathrm{mg} / \mathrm{L}$ \\
Fosfato de potássio dibásico & $10 \mathrm{mg} / \mathrm{L}$ \\
\hline
\end{tabular}

Tabela 4.2 - Composição da solução de micronutrientes.

\begin{tabular}{lc}
\hline \multicolumn{1}{c}{ Composto } & $\begin{array}{c}\text { Quantidade } \\
\text { (q.s.p } 1000 \\
\text { mL) }\end{array}$ \\
\hline Cloreto de cobalto & $0,20 \mathrm{mg} / \mathrm{L}$ \\
Cloreto de manganês & $0,25 \mathrm{mg} / \mathrm{L}$ \\
Permanganato de sódio & $0,05 \mathrm{mg} / \mathrm{L}$ \\
Sulfato de cobre & $0,05 \mathrm{mg} / \mathrm{L}$ \\
Sulfato de ferro & $0,80 \mathrm{mg} / \mathrm{L}$ \\
Sulfato de níquel & $0,05 \mathrm{mg} / \mathrm{L}$ \\
Sulfato de zinco & $0,20 \mathrm{mg} / \mathrm{L}$ \\
\hline
\end{tabular}


Tabela 4.3 - Quantidades adicionadas dos principais componentes para composição do substrato em cada condição operacional de $\mathrm{N}$-amoniacal afluente.

\begin{tabular}{ccc}
\hline $\begin{array}{c}\text { Concentração de } \\
\text { N-amoniacal }\end{array}$ & Composto & $\begin{array}{c}\text { Concentração } \\
(\mathrm{g} / \mathrm{L})\end{array}$ \\
\hline 125 & Sulfato de amônio & 0,60 \\
& Bicarbonato de sódio & 1,7 \\
& Amido & 0,95 \\
\hline 250 & Sulfato de amônio & 1,20 \\
& Bicarbonato de sódio & 3,4 \\
& Amido & 1,9 \\
\hline 500 & Sulfato de amônio & 2,4 \\
& Bicarbonato de sódio & 1,3 e $4 *$ \\
& Amido & 3,8 \\
\hline
\end{tabular}

* quantidades de bicarbonato adicionadas para obter valores de $\mathrm{pH}$ de 7,6, 7,8 e 8,0 , respectivamente.

O bicarbonato de sódio foi escolhido como fonte de alcalinidade por apresentar maior solubilidade que o carbonato de cálcio. A quantidade adicionada deveria suprir a alcalinidade estequiometricamente requerida para a nitrificação de $7,14 \mathrm{mg} \mathrm{CaCO}_{3}^{-}$por mg de amônio oxidado (METCALF e EDDY, 1991). No experimento, manteve-se o pH afluente no valor de 8,0 nas condições operacionais de 125 e $250 \mathrm{mg} \mathrm{N} / \mathrm{L}$, enquanto que na condição operacional de $500 \mathrm{mg} \mathrm{N} / \mathrm{L}$, trabalhou-se com valores de $\mathrm{pH}$ no afluente de 7,6, com a finalidade de diminuir as concentrações iniciais de amônia livre no reator.

Tabela 4.4. Caracterização do substrato em termos de $\mathrm{DQO}, \mathrm{pH}, \mathrm{NH}_{4}^{+}$e alcalinidade.

\begin{tabular}{cccccc}
\hline $\begin{array}{c}\text { Condição } \\
\text { operacional }\end{array}$ & $\begin{array}{c}\mathrm{DQO} \\
(\mathrm{mg} / \mathrm{L})\end{array}$ & $\mathrm{pH}$ & $\mathrm{NH}_{4}^{+}$ & $\begin{array}{c}\mathrm{NH}_{3} \\
\text { (teórico) }\end{array}$ & $\begin{array}{c}\text { Alcalinidade } \\
\text { total }(\mathrm{mg} / \mathrm{L})\end{array}$ \\
\hline 125 & $1021 \pm 174$ & $8,08 \pm 1,00$ & $121 \pm 10$ & 9,4 & $1087 \pm 43$ \\
250 & $1871 \pm 193$ & $8,08 \pm 1,03$ & $239 \pm 13$ & 19,8 & $2304 \pm 122$ \\
500 & $3588 \pm 387$ & $7,86 \pm 1,06$ & $464 \pm 58$ & 23,9 & $3586 \pm 443$ \\
\hline
\end{tabular}

\section{4 - Operação e acompanhamento do sistema}

\subsection{1 - Descrição da operação}

A operação do reator em batelada seqüencial foi feita da seguinte maneira: períodos anóxicos seguidos de períodos aeróbios, com batelada alimentada em cada início de período anóxico e um único período de sedimentação e descarte, completando 
uma batelada de $24 \mathrm{~h}$. A quantidade total alimentada por dia foi de 2 L dividida pelo número de períodos anóxicos. Por exemplo, quando houve cinco períodos anóxicos/aeróbios, como pode ser visto na Figura 4.3, o volume alimentado foi de 400 $\mathrm{mL}$ durante $10 \mathrm{~min}$.

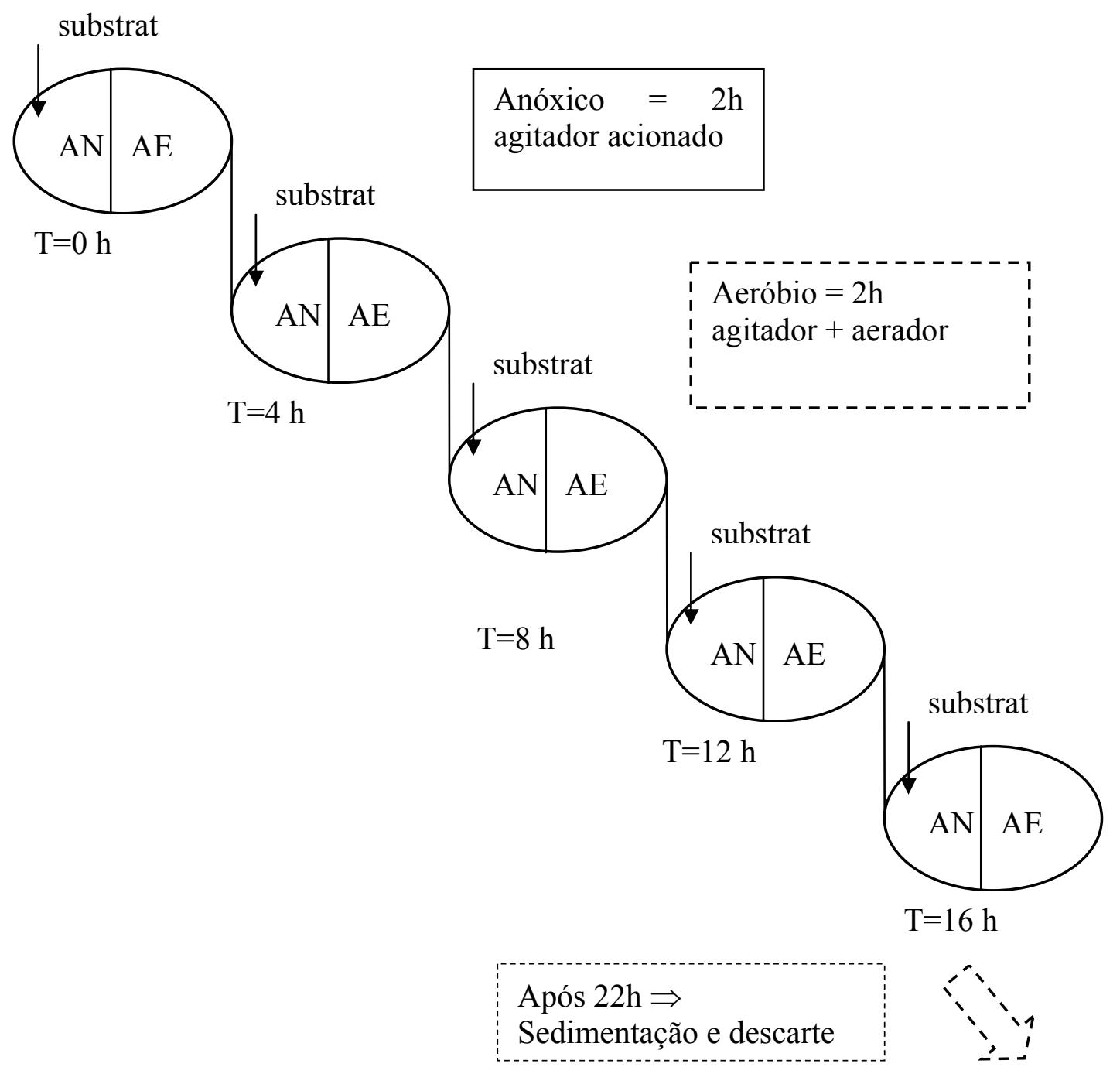

Figura 4.3 - Estratégia operacional do reator aeróbio em batelada seqüencial. Cinco períodos anóxicos/ aeróbios. $\mathrm{AN}=$ anóxico; $\mathrm{AER}=$ aeróbio.

Durante o período anóxico, a aeração era desligada e o agitador permanecia ligado. A fonte de carbono para desnitrificação foi o substrato adicionado em cada período anóxico, que foi utilizado como doador de elétrons para a desnitrificação, reduzindo o nitrato produzido no ciclo anterior. Essa alimentação em batelada foi adicionada após $30 \mathrm{~min}$ do desligamento do aerador, em cada ciclo anóxico/aeróbio. Com isso, garantiu-se que a fonte de carbono adicionada com a batelada fosse consumida essencialmente para a desnitrificação.

Após $22 \mathrm{~h}$ de operação, o agitador era desligado e o descarte era realizado após a 
sedimentação por $1,5 \mathrm{~h}$.

Foi feito monitoramento das amostras do afluente e efluente do reator (freqüência de 2 vezes por semana) com análises de DQO total e filtrada, pH, Namoniacal e alcalinidade a bicarbonato. Objetivou-se avaliar o desempenho do reator em termos de eficiência de remoção de DQO e nitrogênio e da estabilidade do processo com relação a pH e alcalinidade.

Com a obtenção da estabilidade do reator, considerando-se eficiência de remoção de nitrogênio acima de $80 \%$, foram feitos perfis temporais de nitrogênio inorgânico (nas formas de $\mathrm{NH}_{4}^{+}, \mathrm{NO}_{2}^{-}, \mathrm{NO}_{3}^{-}$), potencial redox e $\mathrm{OD}$, ao longo das $24 \mathrm{~h}$, com amostras coletadas a cada 1 h e após a mistura da alimentação.

Realizou-se um ensaio de duração de um ciclo anóxico/aeróbio em todas as condições operacionais, com retirada de amostras periódicas líquidas do reator de $15 \mathrm{em}$ 15 min (condição de 125 e 250 mg N/L) e de 1 h em 1 h (condição de 500 mg N/L), com as medições de potencial redox, oxigênio dissolvido e determinação das concentrações das formas de nitrogênio.

Amostras de lodo foram retiradas periodicamente para análise de sólidos suspensos voláteis (SSV). No final de cada condição operacional foram retiradas amostras para análises microbiológicas e de difração de raio X. Apenas na condição operacional de $125 \mathrm{mgN} / \mathrm{L}$ foi verificada a velocidade de desnitrificação via nitrito e via nitrato.

$\mathrm{Na}$ Tabela 4.5, estão descritas as condições de operação do reator. $\mathrm{O}$ reator não foi reinoculado após o término de cada condição operacional, havendo ocasionais descartes de lodo.

Tabela 4.5 - Descrição das condições das fases de operação - batelada de $24 \mathrm{~h}$

\begin{tabular}{cccccc}
\hline $\begin{array}{c}\text { Concentração } \\
\text { de N-amoniacal } \\
\text { afluente }(\mathrm{mg}\end{array}$ & $\begin{array}{c}\text { Número de } \\
\text { ciclos }\end{array}$ & $\begin{array}{c}\text { Duração de cada } \\
\text { anóxico/aeróbio }\end{array}$ & $\begin{array}{c}\text { Período } \\
(\mathrm{d})\end{array}$ & $\begin{array}{c}\text { Concentração } \\
\text { de oxigênio } \\
\text { dissolvido } \\
(\mathrm{mg} \mathrm{O} / \mathrm{L})\end{array}$ & $\mathrm{pH}$ \\
\hline 125 & 5 & $2 \mathrm{~h} / 2 \mathrm{~h}$ & 180 & $2 \mathrm{a} 2,5$ & 8 \\
& 5 & $2 \mathrm{~h} / 2 \mathrm{~h}$ & 49 & $1 \mathrm{a} 1,5$ & 8 \\
\hline 250 & 5 & $2 \mathrm{~h} / 2 \mathrm{~h}$ & 78 & $2 \mathrm{a} 2,5$ & 8 \\
\hline & 5 & $2 \mathrm{~h} / 2 \mathrm{~h}$ & 86 & $2 \mathrm{a} 2,5$ & 8 \\
& 5 & $2 \mathrm{~h} / 2 \mathrm{~h}$ & 126 & $2,5 \mathrm{a} 3,0$ & 7,6 \\
& 4 & $2 \mathrm{~h} / 4 \mathrm{~h}$ & 57 & $3 \mathrm{a} 4,5$ & 7,6 \\
& 2 & $2 \mathrm{~h} / 4 \mathrm{~h}$ & 42 & $3 \mathrm{a} 5$ & 8,0 \\
& 2 & $2 \mathrm{~h} / 9 \mathrm{~h}$ & 93 & $2,5 \mathrm{a} 3$ & 8,0 \\
\hline
\end{tabular}



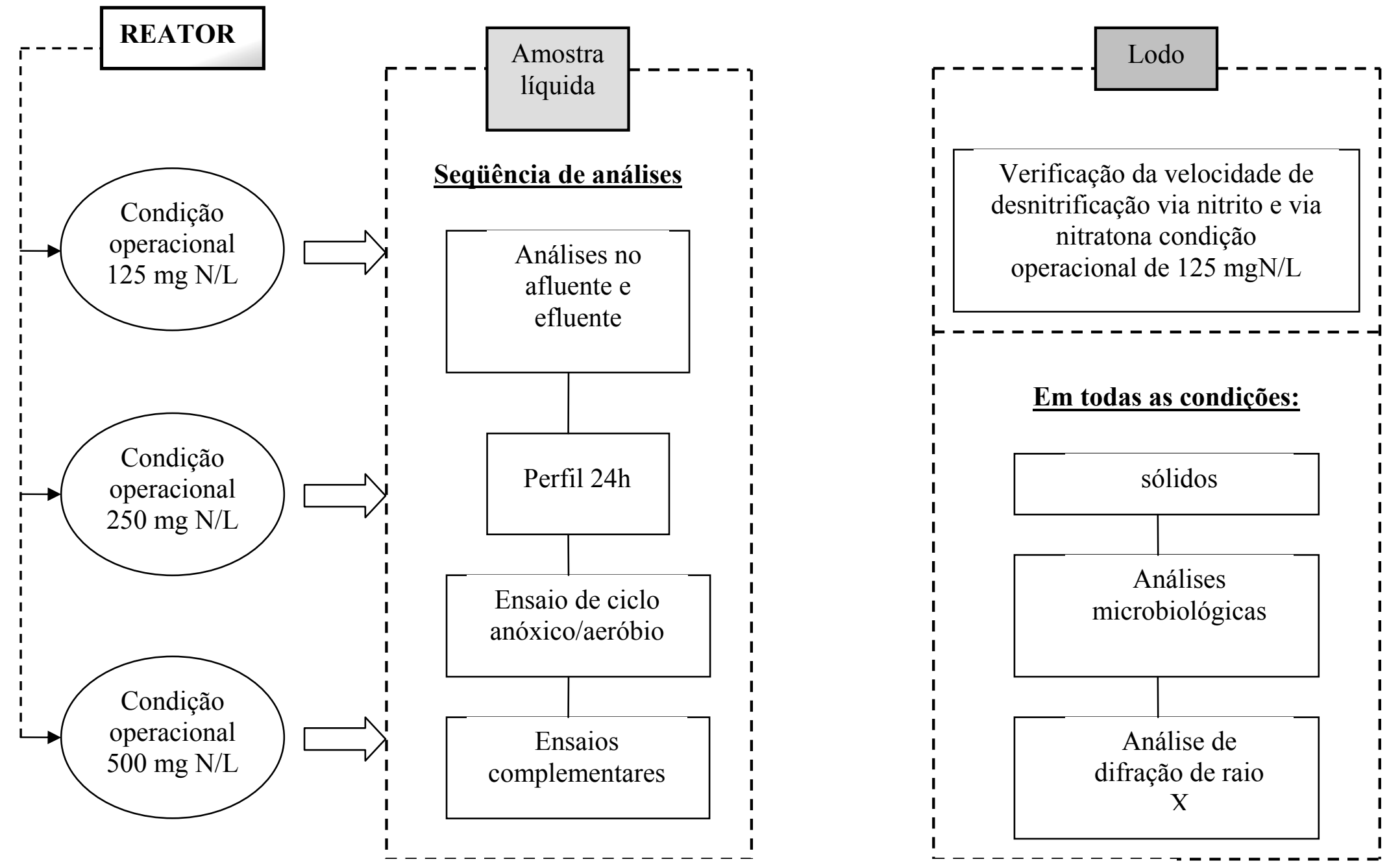

Figura 4.4 - Fluxograma experimental 


\subsection{2 - Ensaio de verificação da velocidade de desnitrificação via nitrito e nitrato}

Esse ensaio foi realizado para avaliação qualitativa da microbiota desnitrificante nos reatores em batelada (escala de bancada). Estimou-se a velocidade de produção de $\mathrm{N}_{2} \mathrm{O}$, composto intermediário da desnitrificação, através do método de inibição da redução enzimática adicionando-se acetileno (YOSHINARI e KNOWLES, 1976).

Para esse ensaio, retirou-se lodo durante operação com condição operacional de $\mathrm{N}$-amoniacal no afluente de $125 \mathrm{mg} \mathrm{N} / \mathrm{L}$. Essa biomassa foi utilizada como inóculo nos dois reatores no ensaio de desnitrificação.

As células foram incubadas com o mesmo substrato que alimentava o reator e, seletivamente com nitrato e nitrito, de acordo com a proposta do ensaio (Tabela 4.6). $\mathrm{O}$ substrato foi composto por meio contendo macro e micronutrientes (modificado de Tanner, 1997), com exclusão da fonte de $\mathrm{N}$-amoniacal (sulfato de amônio).

Tabela 4.6 - Composição do substrato para ensaio de desnitrificação em condição operacional

\begin{tabular}{cccc}
\multicolumn{4}{c}{ de N-amoniacal no afluente de $125 \mathrm{mg} / \mathrm{L} \mathrm{N}}$. \\
\hline Reator & $\begin{array}{c}\text { N-nitrato } \\
(\mathrm{mg} / \mathrm{L})\end{array}$ & $\begin{array}{c}\text { N-nitrito } \\
(\mathrm{mg} / \mathrm{L})\end{array}$ & $\begin{array}{c}\text { amido } \\
(\mathrm{mg} / \mathrm{L})\end{array}$ \\
$\mathrm{R} 2$ & 10 & - & 100 \\
\hline
\end{tabular}

* concentração do amido como mg/L DQO

Os ensaios foram realizados em reatores de $400 \mathrm{~mL}$, sendo $300 \mathrm{~mL}$ destinados ao material reativo (substrato, lodo, macro e micronutrientes) e $100 \mathrm{~mL}$ para gás. $\mathrm{O}$ volume de lodo adicionado foi de $50 \mathrm{~mL}$. Os frascos foram vedados com rolha de borracha e, a seguir $20 \%$ de fase gasosa foi substituída por acetileno, à pressão parcial de $10 \mathrm{kPa}$. Os frascos foram mantidos em temperatura de $\pm 30^{\circ} \mathrm{C}$ e agitados manualmente para manter a homogeneidade da mistura.

A concentração acumulada de $\mathrm{N}_{2} \mathrm{O}$ nos frascos foi determinada por cromatografia a gás, utilizando-se cromátografo Gow Mac (série 150), equipado com detector de condutividade térmica e coluna Porapak Q (800-100 mesh) com $2 \mathrm{~m}$ de comprimento e 1/4" de diâmetro interno, acoplado a integrador processador HP 3396 e hidrogênio $(60 \mathrm{~mL} / \mathrm{min})$ como gás de arraste. A temperatura do forno foi constante 
$\left(30^{\circ} \mathrm{C}\right)$.

Volumes de $1 \mathrm{~mL}$ do biogás retirado da fase gasosa dos reatores foram injetados através de seringa tipo "gás tight" marca "Hamilton". As concentrações acumuladas de $\mathrm{N}_{2} \mathrm{O}$ nos reatores foram calculadas a partir da equação proposta por Tiedje (1982) e adaptada para amostras líquidas.

Os resultados experimentais foram ajustados de acordo com uma função polinomial e as velocidades máximas da produção de $\mathrm{N}_{2} \mathrm{O}$ foram calculadas por regressão linear dos pontos obtidos na fase exponencial. Com esses valores e a concentração de sólidos suspensos voláteis (SSV), foram calculadas as velocidades máximas específicas para cada situação em estudo.

No final do ensaio, foram determinadas as concentrações de nitrito e nitrato para cálculo da eficiência de remoção de nitrogênio.

\subsubsection{Ensaios Complementares}

No final de cada condição operacional $(125,250$ e $500 \mathrm{mg} \mathrm{N} / \mathrm{L})$ foram feitas coletas de amostras líquidas de substrato e efluente para análises de fósforo e de lodo para quantificação de elementos químicos. No final da condição operacional de 500 mg/L N e mantidas as mesmas condições de operação (concentração de OD, duração dos ciclos), realizou-se um ensaio durante o período anóxico com o uso alternativo de etanol como fonte de carbono, com retirada de amostras a cada $15 \mathrm{~min}$.

\section{4 - Análises}

Todas as análises (DQO total e filtrada, nitrato, nitrito, N-amoniacal) foram efetuadas de acordo com Standard Methods for the Examination of Water and Wastewater (2000).

As amostras líquidas coletadas tanto para o perfil temporal quanto para o ensaio de ciclo anóxico/aeróbio foram centrifugadas em $6000 \mathrm{rpm}$ por $5 \mathrm{~min}$, filtradas em filtro de membrana $0,45 \mu \mathrm{m}$ e analisadas. As análises das formas de nitrogênio foram feitas através de análise por injeção de fluxo (FIA - do inglês flow injection analysis).

A concentração de alcalinidade a bicarbonato foi determinada de acordo com metodologia descrita por Ripley et al. (1986). 
As concentrações de $\mathrm{OD}, \mathrm{pH}$ e potencial redox foram medidas por meio de eletrodo de aparelho Orion modelo 810 e modelo 720A, respectivamente.

A concentração de amônia livre (AL) foi quantificada através de equação dada por Anthonisen et al. (1976):

$$
\begin{aligned}
& \mathrm{NH}_{3}=\frac{17 \text { x amônia total como } \mathrm{N} \mathrm{x} 10^{\mathrm{pH}}}{14 \mathrm{~Kb} / \mathrm{Kw}+10^{\mathrm{pH}}} \\
& \text { onde } \mathrm{Kb} / \mathrm{Kw}=\mathrm{e}^{6344 /(273+\mathrm{T})} \\
& \text { sendo } \mathrm{NH}_{3}=\text { concentração de } \mathrm{N}_{\text {comoNH}}\left(\mathrm{mg} \mathrm{N}-\mathrm{NH}_{3} / \mathrm{L}\right) \\
& \mathrm{N}=\text { concentração de } \mathrm{N} \text { como amônia total }(\mathrm{mg} \mathrm{N} / \mathrm{L}) \\
& \mathrm{T}=\text { temperatura }\left({ }^{\circ} \mathrm{C}\right)
\end{aligned}
$$

O balanço iônico na solução aquosa é dado pela Equação 4.2:

$\mathrm{NH}_{4}^{+}+\mathrm{OH}^{-} \Leftrightarrow \mathrm{NH}_{3}+\mathrm{H}_{2} \mathrm{O}$

A concentração de ácido nitroso livre $\left(\mathrm{HNO}_{2}\right)$ foi quantificada através de equação dada por Anthonisen et al. (1976):

$\mathrm{HNO}_{2}=\underline{46 \times \mathrm{N} \text {-nitrito }}$

$14 \mathrm{~K}_{\mathrm{a}} \times 10^{\mathrm{pH}}$

onde $\mathrm{K}_{\mathrm{a}}=\mathrm{e}^{-2300 /(273+\mathrm{T})}$

sendo $\mathrm{HNO}_{2}=$ concentração de $\mathrm{N}$ como $\mathrm{HNO}_{2}\left(\mathrm{mg} \mathrm{N}-\mathrm{HNO}_{2} / \mathrm{L}\right)$

$\mathrm{N}$-nitrito $=$ concentração de $\mathrm{N}$ na forma $\mathrm{NO}_{2}^{-}\left(\mathrm{mg} \mathrm{N}-\mathrm{NO}_{2}^{-} / \mathrm{L}\right)$

$\mathrm{T}=$ temperatura $\left({ }^{\circ} \mathrm{C}\right)$

O balanço iônico na solução aquosa é dado pela Equação 4.4:

$\mathrm{NO}_{2}^{-}+\mathrm{H}_{3} \mathrm{O}^{+} \Leftrightarrow \mathrm{HNO}_{2}+\mathrm{H}_{2} \mathrm{O}$

O fósforo foi quantificado através de análise por injeção de fluxo (FIA - do inglês flow injection analysis) e o lodo seco foi analisado em aparelho de difração de raio $\mathrm{X}$.

O procedimento para determinação das concentrações de etanol foi efetuada de acordo com Correia e Pedroso (1997) e das concentrações de ácidos voláteis por cromatografia gasosa de acordo com Moraes et al. (2000). Essas análises em particular foram realizadas pela técnica Elizabeth M. Moraes. 


\section{5 - Exames Microbiológicos}

Os exames microbiológicos e os ensaios de Biologia Molecular foram realizados pela pesquisadora Dra. Eloísa Pozzi, técnica do Laboratório de Processos Biológicos do Departamento de Hidráulica e Saneamento da Escola de Engenharia de São Carlos, com a colaboração do pesquisador Dr. Fabio Alexandre Chinalia e da bolsista de Iniciação Científica Ana Lucia Gerardi Spínola (FAPESP- 05/52150-0).

Foram realizadas as seguintes análises:

1. Microscopia ótica comum e de contraste de fase do lodo no final da etapa de operação com concentração de N-amoniacal afluente de 125, 250 e 500 mg N/L

2. Estimativa do Número Mais Provável (NMP) de organismos nitrificantes e desnitrificantes no final de cada condição operacional;

3. Isolamento de cepas desnitrificantes para posterior identificação desses organismos;

4. Identificação das cepas desnitrificantes isoladas:

4.1. Microscopia ótica comum e de contraste de fase;

4.2. Ensaios de coloração de Gram, Neisser e PHA;

4.3. Extração de DNA e amplificação de DNAr $16 \mathrm{~S}$ pela técnica de PCR (Polimerase Chain Reaction);

4.4. Clonagem e seqüenciamento.

O fluxograma dos exames microbiológicos é apresentado na Figura 4.4.

\subsection{1 - Exames microscópicos}

Foram realizados exames de microscopia ótica comum e de contraste de fase no lodo do reator no final de cada condição operacional. Foi utilizado microscópio "Leica", acoplado à câmera com captura de imagem e software Image-Pro Plus. Na condição de $500 \mathrm{mg} \mathrm{N} / \mathrm{L}$, foram realizados ensaios de coloração de Neisser para averiguação de depósitos intracelulares de polifosfato (JENKINS et al., 2003) 


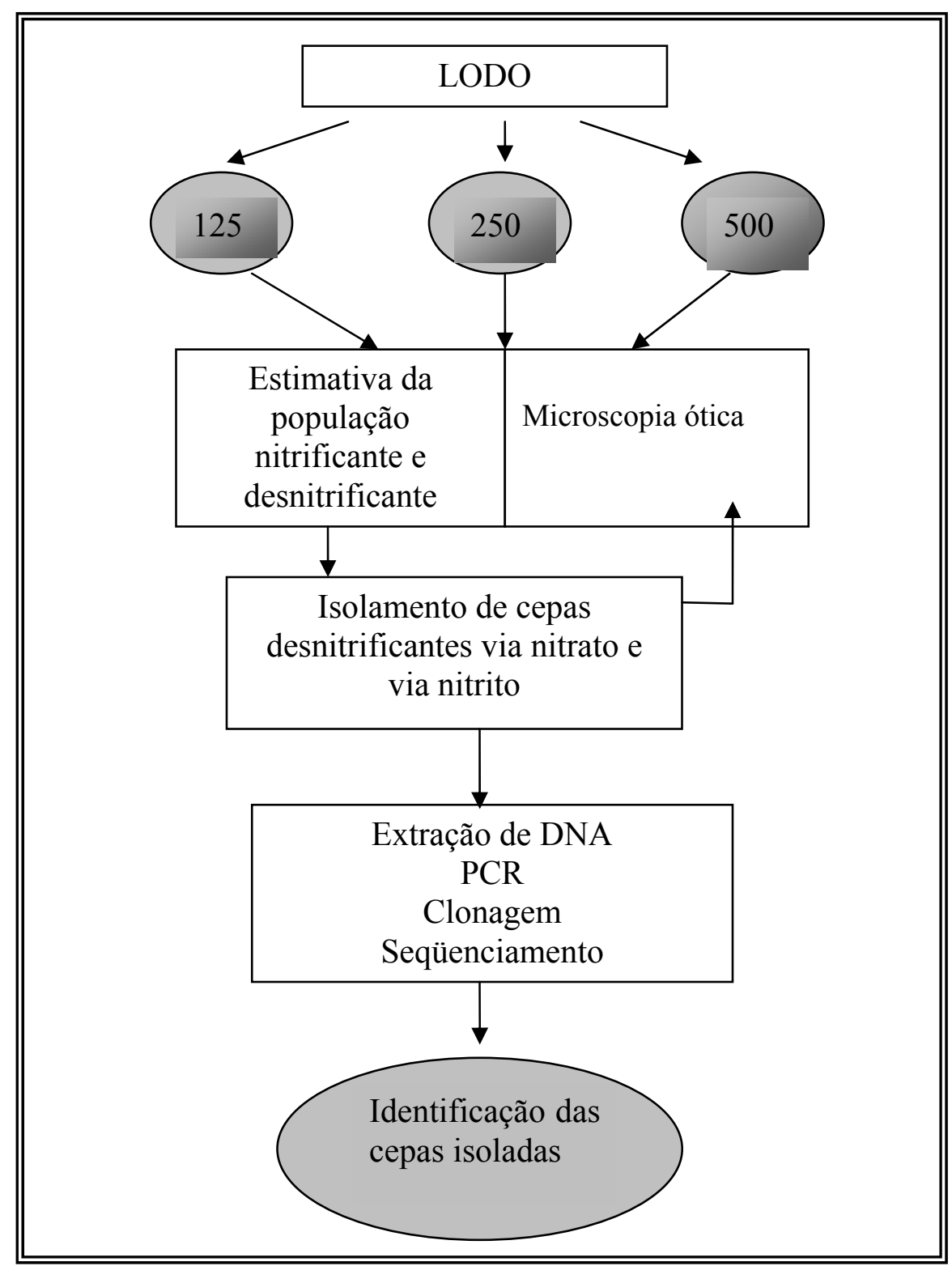

Figura 4.4 - Fluxograma da seqüência dos exames microbiológicos.

\subsection{2 - Estimativa da população de organismos nitrificantes e desnitrificantes}

A estimativa da população de organismos nitrificantes e desnitrificantes foi efetuada no final de cada fase do experimento, antes de se alterar a concentração de Namoniacal afluente. Assim, as amostras de lodo foram retiradas no final da operação com N-amoniacal afluente de $125 \mathrm{mg} \mathrm{N} / \mathrm{L}, 250 \mathrm{mg} \mathrm{N} / \mathrm{L}$ e $500 \mathrm{mg} \mathrm{N} / \mathrm{L}$.

A estimativa da microbiota nitrificante presente no reator (oxidantes de $\mathrm{N}$ amoniacal e de nitrito), foi feita através de diluições seriadas das bactérias presentes no lodo. Nesse ensaio, foi utilizado o meio descrito por Schmidt e Belser (1982), o qual foi 
adaptado para amostras líquidas (Tabela 4.6).

Tabela 4.6 - Sais minerais e elementos-traço para crescimento de organismos nitrificantes.

\begin{tabular}{|c|c|c|c|}
\hline \multirow{2}{*}{$\begin{array}{l}\text { Constituinte } \\
\text { químico }\end{array}$} & \multirow{2}{*}{$\begin{array}{c}\text { Concentração na } \\
\text { solução estoque } \\
(\mathrm{g} / 100 \mathrm{~mL})\end{array}$} & Solução requerida & para $1 \mathrm{~L}$ de meio \\
\hline & & $\begin{array}{c}\text { Oxidantes de N- } \\
\text { amoniacal } \\
(\mathrm{mL})\end{array}$ & $\begin{array}{l}\text { Oxidantes de } \\
\text { nitrito } \\
(\mathrm{mL})\end{array}$ \\
\hline
\end{tabular}

\begin{tabular}{lccc}
\hline Sais & 5 & 10 & - \\
$\left(\mathrm{NH}_{4}\right)_{2} \mathrm{SO}_{4}$ & 0,85 & - & 1 \\
$\mathrm{KNO}_{2}$ & 1,34 & 1 & 1 \\
$\mathrm{CaCl}_{2} \cdot 2 \mathrm{H}_{2} \mathrm{O}$ & 4 & 1 & 5 \\
$\mathrm{MgSO}_{4} \cdot 7 \mathrm{H}_{2} \mathrm{O}$ & 0,04 & 5 & - \\
$\mathrm{Azul} \mathrm{de}$ bromotimol & 3,48 & - & 4 \\
$\mathrm{~K}_{2} \mathrm{HPO}_{4}$ & 2,72 & 7,5 & 1 \\
$\mathrm{KH}_{2} \mathrm{PO}_{4}$ & & 1 & 1 \\
\hline Ferro quelante & 0,246 & & \\
$\mathrm{FeSO}_{4} \cdot 7 \mathrm{H}_{2} \mathrm{O}$ & 0,331 & 1 & \\
$\mathrm{EDTA} \mathrm{dissolvido}_{\text {Elementos-traço }}$ & 0,01 & & \\
$\mathrm{NaMoO}_{4} \cdot 2 \mathrm{H}$ & $\mathrm{O}$ \\
$\mathrm{MnCl}_{2}$ & 0,02 & & \\
$\mathrm{CoCl}_{2} 6 \mathrm{H}_{2} \mathrm{O}$ & 0,0002 & & \\
$\mathrm{ZnSO}_{4} \cdot 7 \mathrm{H}_{2} \mathrm{O}$ & 0,01 & & \\
$\mathrm{CuSO}$ & $5 \mathrm{H}_{2} \mathrm{O}$ & 0,002 &
\end{tabular}

Fonte: SCHMIDT e BELSER (1982)

Para a estimativa das bactérias desnitrificantes do reator em batelada, foi utilizado como meio de cultura o mesmo substrato sintético basal (adaptado de Tanner, 1997) descrito no item 4.2., com exceção da fonte de nitrogênio (sulfato de amônio). Nitrato e nitrito foram adicionados como aceptores terminais de elétrons e o amido como fonte de carbono para a desnitrificação. O método empregado é o descrito por Tiedje (1982) e adaptado para amostras líquidas.

A estimativa da população de bactérias nitrificantes e desnitrificantes foi realizada considerando-se a combinação das respostas positivas, utilizando-se a tabela padrão de probabilidade, segundo Alexander (1982).

\subsection{2 - Isolamento de cepas desnitrificantes nas amostras retiradas do reator na condição operacional de $\mathrm{N}$-amoniacal afluente de 125, 250 e $500 \mathrm{mg} \mathrm{N} / \mathrm{L}$}

A partir do resultado positivo do ensaio anterior, realizou-se o isolamento de cepas desnitrificantes. A confirmação do crescimento de cepas desnitrificantes 
purificadas via nitrito tornou-se evidente pelo consumo de nitrito, verificado pela reação qualitativa após adição da sulfanilamida e n-naftil (JENKINS et al., 2003). De modo similar, a confirmação do crescimento de cepas desnitrificantes purificadas via nitrato foi validada pelo consumo de nitrato, determinado pela reação qualitativa após a adição de difenilamina em ácido sulfúrico (TIEDJE, 1982). Além disso, foi confirmada a produção de $\mathrm{N}_{2} \mathrm{O}$ como composto intermediário do processo de desnitrificação, conforme descrito no item 4.3.3 (YOSHINARI e KNOWLES, 1976).

Após a confirmação da purificação das cepas desnitrificantes, as células foram visualizadas por meio de microscopia óptica comum (coloração de Gram, Neisser e PHB - JENKINS et al., 2003) e contraste de fase. Posteriormente, essas cepas foram submetidas à extração de DNA e ampliação de DNA ribossomal 16S (PCR), clonagem e seqüenciamento para identificação filogenética.

\subsection{3 - Identificação filogenética das cepas isoladas}

A extração de DNA foi realizada através do método direto utilizando glass beads e mistura de fenol: clorofórmio: tampão $(1: 1: 1 \mathrm{v} / \mathrm{v})$ seguindo o procedimento descrito por Griffiths et al. (2000). Segmentos de DNA de aproximadamente 800 pares de bases $(\mathrm{pb})$ do ribossomo $16 \mathrm{~S}$ foram amplificados em reações de PCR utilizando “eubacterial primers” 27F (5' AGA GTT TGA TCC TGG CTC AG 3') e 907 R (5' CCG TCA ATT CCT AGT TT 3'), seguindo metodologia descrita por So e Young (1999).

As amostras dos produtos de PCR (DNAr 16S de aproximadamente $800 \mathrm{pb}$ ) foram clonadas em plasmídeo pCR 2.1 TOPO-TA "easy vector system-Invitrogen". Células competentes de E. Coli $\mathrm{DH} \alpha 5$ foram transformadas com o plasmídeo seguindo metodologia descrita pelo fabricante. Foram seqüenciados entre 5 a 10 clones de cada cepa de bactéria desnitrificante isolada do reator. O seqüenciamento dos nucleotídeos foi realizado em seqüenciador ABI 377 DNA Sequencer (Perkin Elmer). Foram utilizados "primers" M13 forward e reverse, respectivamente. As seqüências obtidas foram agregadas e alinhadas usando DNASTAR-Package Software (Lasergene Sequence Analysis). Depois do alinhamento e averiguação da presença de quimeras, as seqüências de nucleotídeo foram comparadas às seqüências do banco de dados eletrônico NCBI-database para a aproximação da identidade filogenética. 


\section{5 - RESULTADOS E DISCUSSÕES}

\section{1 - Concentração de N-amoniacal afluente de $125 \mathrm{mg} \mathrm{N} / \mathrm{L}$ - considerações gerais.}

A operação em concentração de N-amoniacal afluente de $125 \mathrm{mg} \mathrm{N} / \mathrm{L}$ foi efetuada em concentração média de $\mathrm{OD}$ de $2 \mathrm{mg} \mathrm{O} / \mathrm{L}$, que resultou em nitrato, como produto final da nitrificação. Como a alimentação foi em regime de batelada alimentada, a concentração de $\mathrm{N}$-amoniacal no reator a cada ciclo foi diluída numa proporção de 10 vezes menor do que a concentração de nitrogênio adicionada (como pode ser visto na Figura 5.4). A estratégia de alimentação batelada pode melhorar a distribuição de doadores de elétrons (TILCHE et al., 1999) e pode evitar a inibição por substrato através de diluição (POO et al., 2004).

Segundo Alleman e Irvine (1980), Surampalli et al. (1997) e Jenkins et al. (2003), a alimentação na fase anóxica tem a finalidade de se fazer uso dos compostos orgânicos prontamente biodegradáveis disponíveis na água residuária e aumentar a velocidade de desnitrificação. Alleman e Irvine (1980) e Jenkins et al. (2003) apontam como outra vantagem, a ocorrência de um mecanismo de indução de estocagem no floco, portanto fonte necessária de elétrons e também age como seletor que evita organismos filamentosos.

No $5^{\circ}$ período aeróbio, o produto final, após a sedimentação, foi o nitrato, pois não havia fonte de carbono suficiente para desnitrificá-lo (como pode ser visto na Figura 5.5a). Portanto, adicionou-se um sexto período anóxico alimentado no programa de operação do reator, a partir do $100^{\circ}$ dia.

De acordo com a literatura, a baixa concentração de OD pode ser o fator que leva à nitrificação via nitrito, mas alguns autores listados no Quadro 3.6 afirmaram que esse não foi o fator predominante. Portanto, com a finalidade de testar essa teoria, diminuiu-se a concentração de OD para valores de $1,5 \mathrm{mg} \mathrm{O}_{2} / \mathrm{L}$. 
$\mathrm{Na}$ concentração de $\mathrm{OD}$ de $1,5 \mathrm{mg} \mathrm{O}_{2} / \mathrm{L}$, embora a eficiência de remoção de nitrogênio tenha aumentado, houve crescimento significativo de bactérias filamentosas, porém a eficiência foi mantida em termos de remoção de nitrogênio, como pode ser observado na Tabela 5.1. O produto final da nitrificação continuou sendo nitrato.

Aumentou-se novamente a concentração de OD para $2 \mathrm{mg} \mathrm{O} / \mathrm{L}$, com a obtenção dos mesmos resultados iniciais (Tabela 5.1 e Figura 5.1), isto é, eficiência de remoção de nitrogênio acima de $80 \%$ com predominância de nitrato como produto da nitrificação.

Tabela 5.1 - Eficiências médias de remoção de nitrogênio (considerando as três formas: amoniacal, nitrato e nitrito) e porcentagem de nitrato no efluente em relação ao total de formas oxidadas $\left(\mathrm{NO}_{3}^{-} / \mathrm{N}^{-}\right.$ox $)$.

\begin{tabular}{clll}
\hline $\mathrm{OD}\left(\mathrm{mg} \mathrm{O}_{2} / \mathrm{L}\right)$ & Duração (dia) & $\begin{array}{l}\text { Eficiência de } \\
\text { remoção }(\%)\end{array}$ & $\begin{array}{c}\mathrm{NO}_{3}^{-} / \text {Nox no efluente } \\
(\%)\end{array}$ \\
\hline 2 & 1 a $118 \mathrm{~d}$ & $86 \pm 15(55-98)$ & $95 \pm 5(83-100)$ \\
1,5 & 119 a 168 d & $95 \pm 3(92-98)$ & $82 \pm 46(91-100)$ \\
2 & 169 a 231 d & $88 \pm 14(42-100)$ & $87 \pm 30(61-100)$ \\
\hline
\end{tabular}

\subsection{1 - Remoção de nitrogênio}

\subsubsection{1 - Análise geral - monitoramento}

As eficiências de remoção de nitrogênio, considerando-se as três formas de nitrogênio: $\mathrm{N}$-amoniacal no afluente e efluente, nitrato e nitrito no efluente foram acima de $80 \%$, para a concentração de OD de $2 \mathrm{mg} \mathrm{O}_{2} / \mathrm{L}$. Apesar do intenso crescimento de filamentosas, a eficiência de remoção de nitrogênio na concentração de OD em 1,5 mg $\mathrm{O}_{2} / \mathrm{L}$ permaneceu alta (acima de 95\%), como pode ser observada na Figura 5.1.

A variação da concentração de sólidos suspensos (SSV) e Índice Volumétrico de Lodo (IVL) podem ser observadas na Tabela 5.2. Durante a condição operacional de $125 \mathrm{mg} \mathrm{N} / \mathrm{L}$, houve esporádicos descartes de lodo, apenas para controle da concentração média de SSV. 


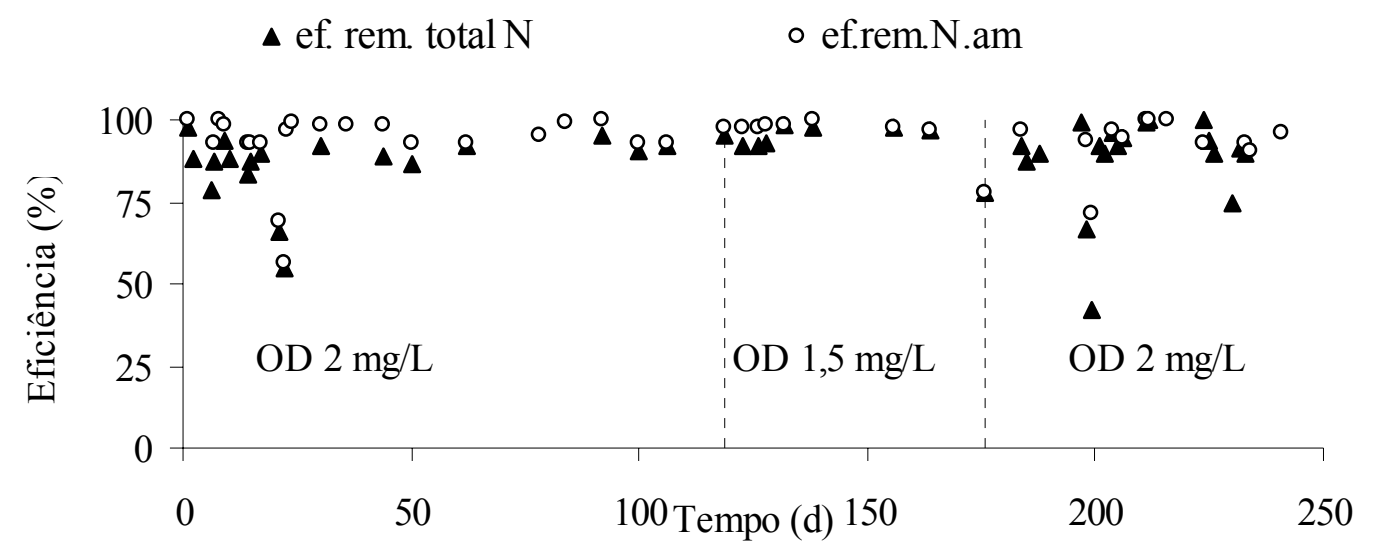

Figura 5.1 - Eficiências de remoção de nitrogênio durante a condição operacional de $125 \mathrm{mg}$ N/L e sob duas condições de concentração de OD.

Tabela 5.2. Caracterização física (SSV e IVL) do lodo durante a condição operacional de 125 $\mathrm{mg} \mathrm{N} / \mathrm{L}$.

\begin{tabular}{cccc} 
& \multicolumn{3}{c}{$\mathrm{mg} \mathrm{N} / \mathrm{L}}$. \\
\hline $\mathrm{OD}\left(\mathrm{mg} \mathrm{O}_{2} / \mathrm{L}\right)$ & & $\mathrm{SSV}(\mathrm{g} / \mathrm{L})$ & IVL $(\mathrm{mL} / \mathrm{g})$ \\
\hline 2 & Inicial & 5,6 & 111 \\
& Média & $6,5 \pm 1,0$ & \\
\hline 1,5 & Média & $5,8 \pm 0,3$ & 136 \\
\hline 2 & Inicial & 3,2 & \\
& Média & $4,35 \pm 0,7$ & 93 \\
\hline
\end{tabular}

Valores de IVL entre 50-100 são indicadores de boa sedimentabilidade em lodo de sistemas de lodos ativados (VON SPERLING, 1997). Observa-se que as concentrações de SSV foram muito superiores às encontradas em sistemas de lodos ativados convencionais, sendo que, neste caso, o IVL deve ser considerado apenas como parâmetro indicativo da sedimentabilidade do lodo.

Pambrum et al. (2004) relataram que a relação de SSV/SST de 0,8 é a ideal para operação de sistemas de lodos ativados convencionais e que valores menores indicam que a quantidade de substâncias minerais está em proporção maior que o usual. No experimento, durante operação com concentração de OD de $2 \mathrm{mg} \mathrm{O}_{2} / \mathrm{L}$, atingiu-se valor médio de SSV/SST de 0,82 no lodo e durante operação com concentração de OD de 1,5 $\mathrm{mg} \mathrm{O}_{2} / \mathrm{L}$ atingiu-se valor médio de 0,81 . Conclui-se que a fração volátil no lodo encontrava-se em valor adequado para a operação do sistema.

O exame microscópico do lodo do reator para a concentração de OD de $2 \mathrm{mg}$ $\mathrm{O}_{2} / \mathrm{L}$ é apresentado na Figura 5.2. Os organismos identificados visualmente ao microscópio foram semelhantes a Microthrix parvicella, Thiothrix sp., Nostocoida limicola (JENKINS et al., 2003), protozoários (ciliados pedunculados, amebas e cistos), metazoários (rotíferos e nematóides), com predominância dos filamentos. 
Após a diminuição da concentração de OD para 1,5 mg $\mathrm{O}_{2} / \mathrm{L}$, foram observados organismos zoogloeiais, cocos, bacilos, sarcinas, bactérias semelhantes a Microthrix parvicella e ao tipo $021 \mathrm{~N}$. Aparentemente, houve um predomínio dessas bactérias filamentosas, como pode ser visto na Figura 5.3. A configuração das bactérias mostrada nessa figura não aparecia na concentração de OD de $2 \mathrm{mgO}_{2} / \mathrm{L}$.
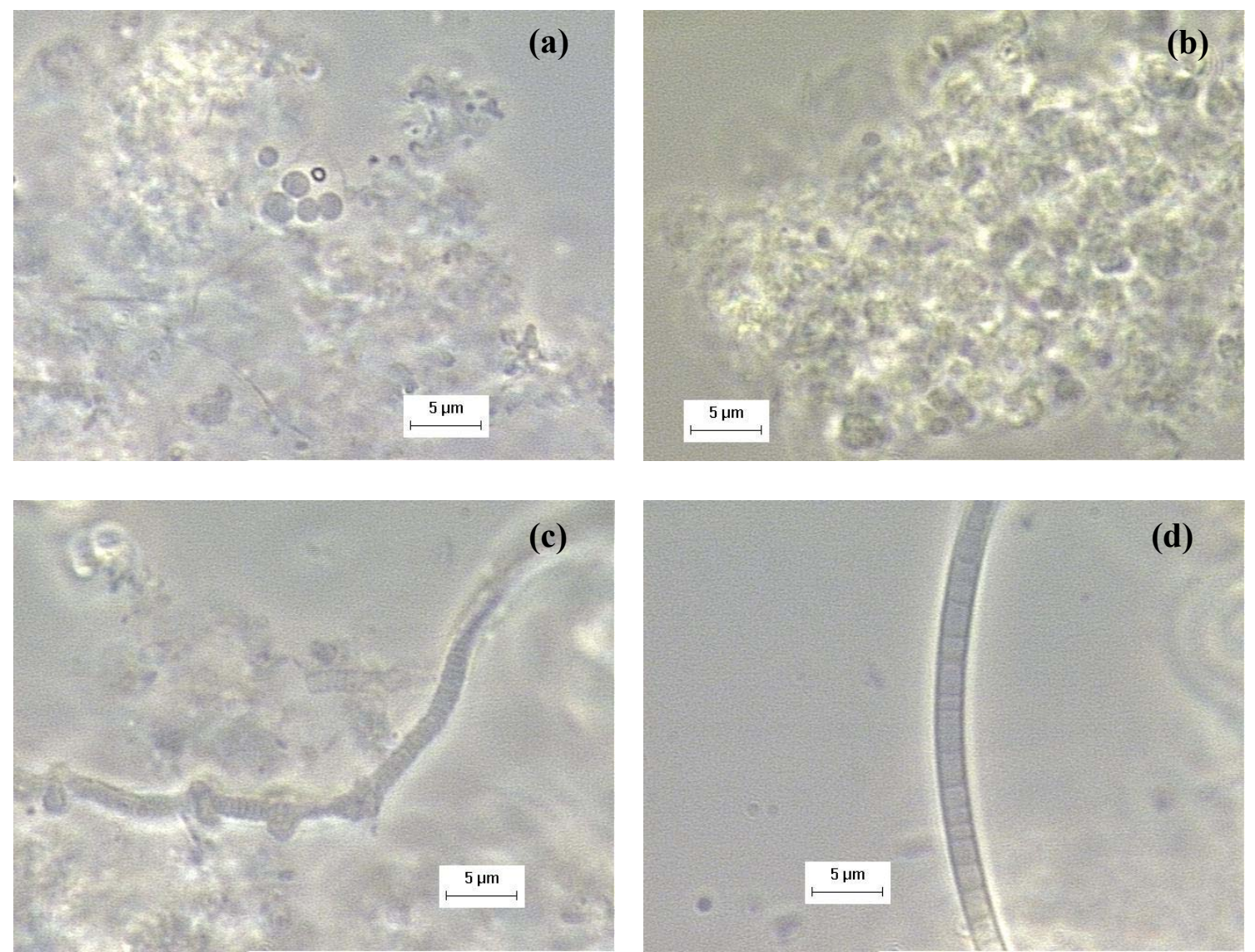

Figura 5.2 - Microfotografias do lodo no final da condição operacional de125 mg N/L e concentração de OD de $2 \mathrm{mg} \mathrm{O} / \mathrm{L}$ : (a) cocos; (b) arranjo de cocos; (c) filamentosas semelhante a Microthrix parvicella; (d) filamento semelhante ao tipo $021 \mathrm{~N}$.

JENKINS et al. (2003) relatam que ocorre entumescimento do lodo (bulking) ocasionado por filamentosas em sistemas de lodos ativados, quando o reator está sob condições estressantes: baixa concentração de $\mathrm{OD}$, baixa relação $\mathrm{A} / \mathrm{M}$, elevada concentração de ácidos orgânicos de baixo peso molecular, baixo pH e deficiência de nutrientes (N e P). Segundo esses autores, devem ser mantidas, no efluente de sistemas de lodos ativados, as concentrações de nitrogênio solúvel inorgânico maiores que 0,5 a $1 \mathrm{mg} \mathrm{N} / \mathrm{L}$ e de fósforo maiores que 0,1 a $0,3 \mathrm{mg} \mathrm{P} / \mathrm{L}$, garantindo-se, desse modo, que não haja deficiência de nutrientes.

Essa predominância de organismos filamentosos pode levar à competição por substrato (carboidrato ou doador de elétrons) e o nitrato pode ser usado no período 
anóxico. Adicionalmente, Jenkins et al. (2003) relataram que lodo com predominância de Microthrix parvicella, provindo de sistema de lodos ativados com atividade prédesnitrificante, pode desnitrificar e formar produtos de estocagem com o uso de substratos de carbono simples. Além disso, a presença de Microthrix está associada à remoção de fósforo (SOUSA, 1996). Isso explicaria porque a eficiência de remoção de nitrogênio não foi muito prejudicada pelo uso dessas vias alternativas de desnitrificação por esses microrganismos. No entanto, a sedimentabilidade do lodo não estava adequada, possivelmente por causa do entumescimento do lodo ocasionado por tais bactérias filamentosas, o que prejudicou a qualidade do efluente.

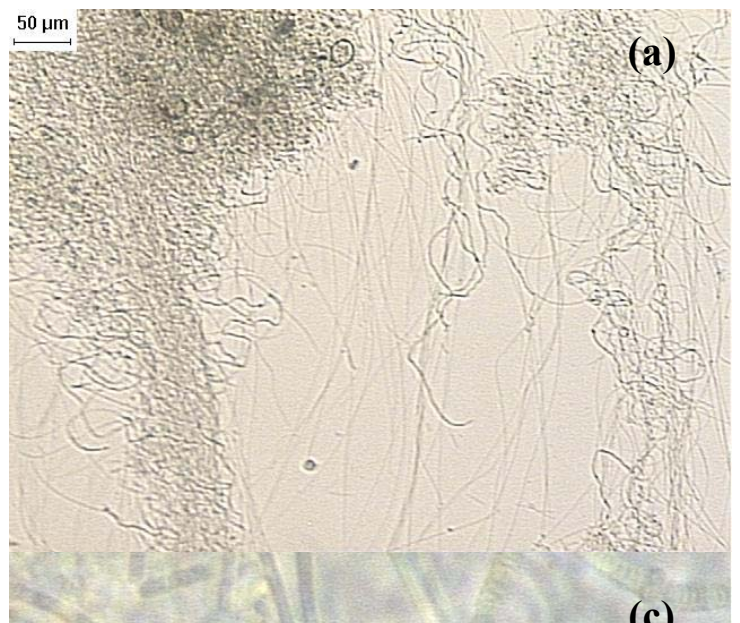

(c)

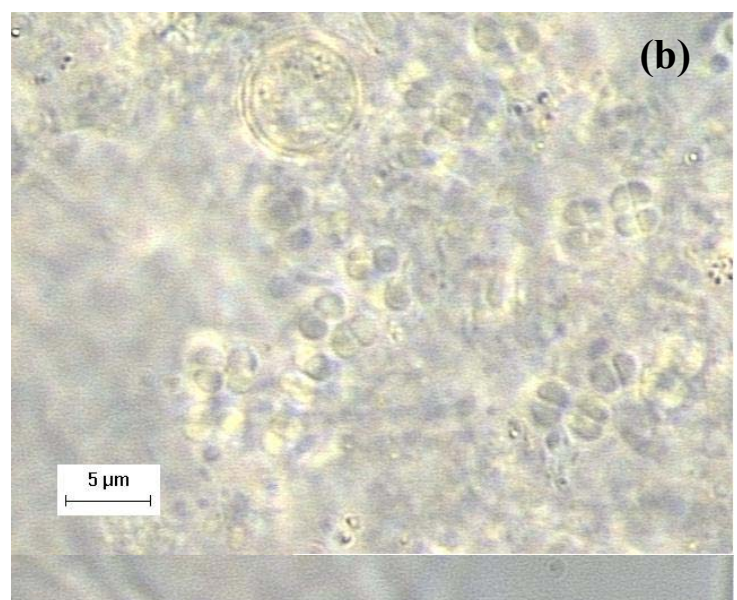

(d)
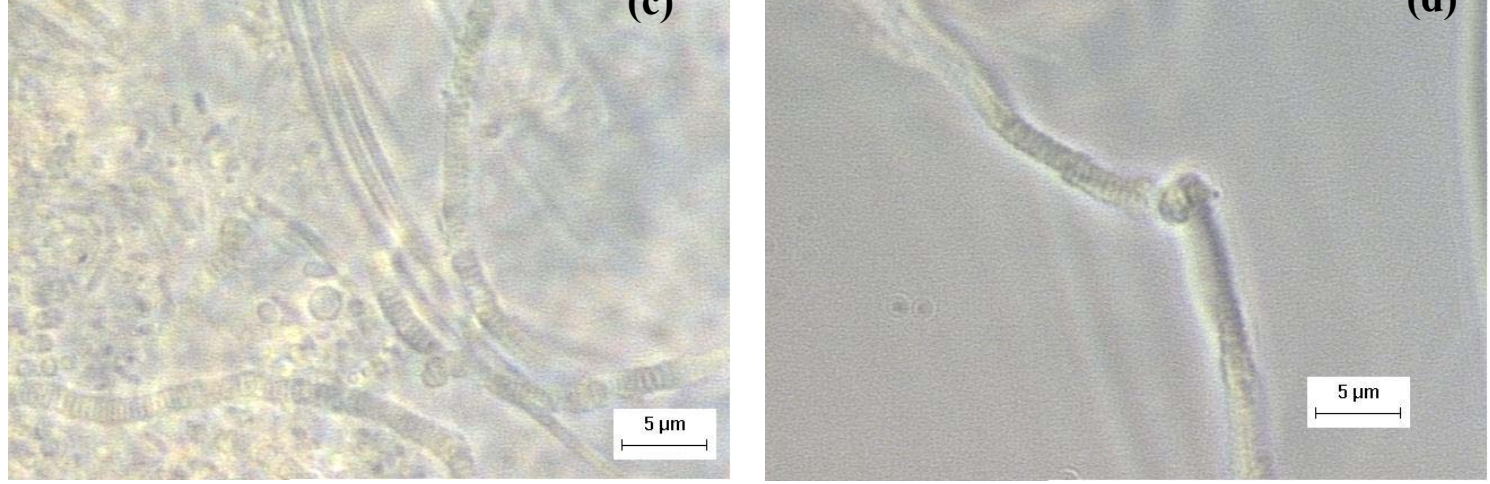

Figura 5.3 - Microfotografias do lodo no final da condição operacional de $125 \mathrm{mg}$ N/L e concentração de OD de 1,5 $\mathrm{mg} \mathrm{O}_{2} / \mathrm{L}$ : (a) bactérias filamentosas; (b) sarcinas; (c) bactérias filamentosas; (d) bactéria semelhante a Nostocoida limicola.

Microthrix parvicella e a bactéria tipo $021 \mathrm{~N}$ estão associadas com as condições mais adversas para microrganismos que estão presentes em sistemas de lodos ativados: deficiência de nutrientes e carbono e baixa concentração de OD. Thiothrix sp e tipo 021 $\mathrm{N}$ são organismos encontrados em condições de baixa concentração de nitrogênio. Nostocoida limicola é encontrada em condições de deficiência de fósforo e na presença de açúcares simples e amido (JENKINS et al., 2003).

$\mathrm{Na}$ tentativa de diminuir-se o número de bactérias filamentosas com a finalidade 
de melhorar a qualidade do efluente, as condições de operação do reator foram alteradas, aumentando-se a concentração de fósforo adicionada: $2 \mathrm{~mL}$ da solução de sais $/ \mathrm{L}$ de substrato preparado e a concentração de OD para $2 \mathrm{mg} \mathrm{O}_{2} / \mathrm{L}$.

$\mathrm{O}$ efeito foi imediato. Em poucos dias, o lodo recuperou a sedimentabilidade e também a eficiência de remoção de nitrogênio. Foram detectados protozoários semelhantes a Aspidisca, Euglypha e flagelados. Os protozoários do gênero Aspidisca alimentam-se de bactérias nitrificantes e são indicadores de processo de nitrificação bem sucedido (SOUSA, 1996).

Há três pontos a serem observados:

- Mesmo com entumescimento do lodo, a eficiência de remoção de nitrogênio não foi alterada, fato esse evidenciado nos gráficos da variação temporal das formas nitrogenadas que foram similares para concentração de OD de 1,5 $\mathrm{mg} \mathrm{O}_{2} / \mathrm{L}$ e de 2 mg $\mathrm{O}_{2} / \mathrm{L}$. Entretanto, a qualidade do efluente em termos de DQO, foi inferior na concentração de OD de 1,5 mg $\mathrm{O}_{2} / \mathrm{L}$ (Tabela 5.3);

- Considerando-se que a fonte de carbono (amido) fermentaria no período anóxico resultando numa considerável produção de ácidos voláteis, portanto estimulando o crescimento desses microrganismos filamentosos, realizou-se um perfil temporal das concentrações de ácidos voláteis graxos (AVG) durante as $2 \mathrm{~h}$ do período anóxico, apenas na concentração de N-amoniacal de $500 \mathrm{mg} \mathrm{N} / \mathrm{L}$ (ver dados no Apêndice, Tabela A.11). As concentrações variaram de 0 a $8,8 \mathrm{mg} / \mathrm{L}$ de ácido acético, com traços de ácido isovalérico e de ácido propiônico, concentrações que possivelmente não são suficientes para servir como principal substrato para tais microrganismos;

- A fonte de carbono escolhida, amido, não foi a principal causa do entumescimento do lodo em concentração de $125 \mathrm{mg} \mathrm{N} / \mathrm{L}$, uma vez que, em concentrações mais elevadas de $\mathrm{N}$-amoniacal no afluente (250 e $500 \mathrm{mg} \mathrm{N} / \mathrm{L}$ ) não ocorreu esse fenômeno.

\subsubsection{2 - Análise pontual - Análise de uma batelada de 24 h.}

A concentração de $\mathrm{N}$-amoniacal adicionada e consumida na nitrificação pode ser observada na Figura 5.4, que mostra a variação temporal desse íon ao longo da batelada. A estratégia de batelada alimentada promoveu a diluição do $\mathrm{N}$-amoniacal afluente. A concentração de $\mathrm{N}$-amoniacal no reator, a cada ciclo foi diluída para valores da ordem 
dez vezes menores que a concentração de nitrogênio adicionada.

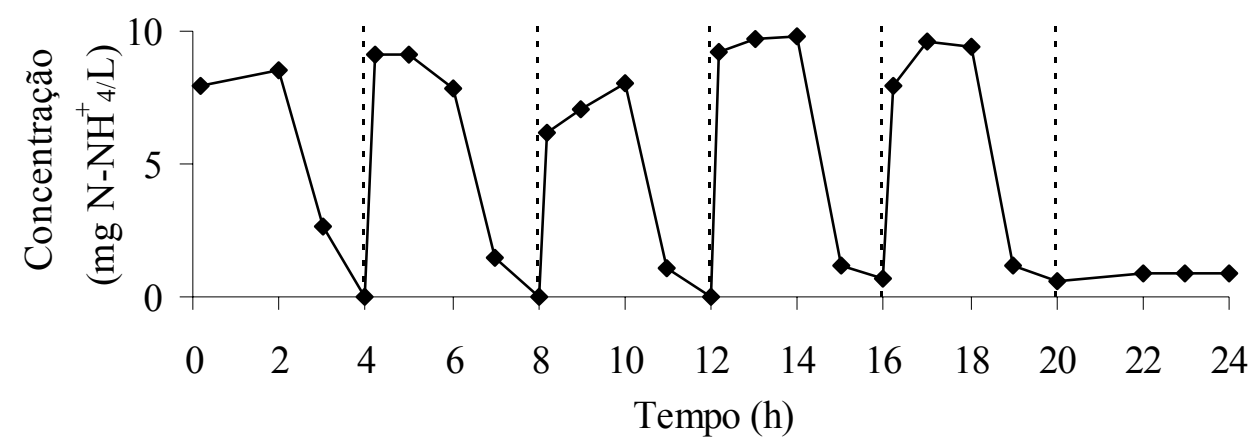

Figura 5.4 - Variação temporal das concentrações de $\mathrm{N}$-amoniacal durante condição operacional de $125 \mathrm{mg} \mathrm{N} / \mathrm{L}$ em concentração média de OD de $2 \mathrm{mg} \mathrm{O} / 2$ aos 84 dias de experimento.

Observou-se que após a primeira hora de cada período aeróbio, que a concentração média de $\mathrm{N}$-amoniacal era de $1,5 \mathrm{mg} \mathrm{N} / \mathrm{L}$, indicando que houve $85 \%$ de consumo de $\mathrm{N}$-amoniacal nessa primeira hora. Ao longo dos ciclos, a concentração de $\mathrm{N}$-amoniacal no final de cada período aeróbio foi menor comparada com a do período aeróbio anterior. $\mathrm{O}$ produto final da nitrificação para a concentração de OD de $2 \mathrm{mg}$ $\mathrm{O}_{2} / \mathrm{L}$ foi o nitrato (Tabela 5.1), que foi desnitrificado no período anóxico subseqüente, como pode ser observado pela variação temporal das concentrações de nitrato apresentadas nas Figuras 5.5a e 5.5b.

$\mathrm{Na}$ Figura 5.5a, observa-se que não havia fonte de carbono suficiente para desnitrificar o nitrato resultante do quarto período aeróbio. A partir do $100^{\circ}$ dia, modificou-se a estratégia operacional, adicionando-se mais um período anóxico alimentado, provendo fonte de carbono suficiente para a desnitrificação, conforme pode ser visto na Figura 5.5b.

Quando a aeração foi retomada, o nitrato foi novamente produzido com consumo de $\mathrm{N}$-amoniacal, indicando que o período anóxico anterior não afetou negativamente a atividade das bactérias nitrificantes.

Efetuou-se o perfil referente aos 180 dias com a finalidade de conferir o comportamento da variação temporal das formas de nitrogênio após o retorno da concentração de OD para $2 \mathrm{mg} \mathrm{O}_{2} / \mathrm{L}$. A concentração média de nitrato, em ambos os perfis temporais foi de $10 \mathrm{mg} \mathrm{N}-\mathrm{NO}_{3}^{-} / \mathrm{L}$, mostrando que houve oxidação de todo $\mathrm{N}$ amoniacal adicionada em cada período anóxico. 


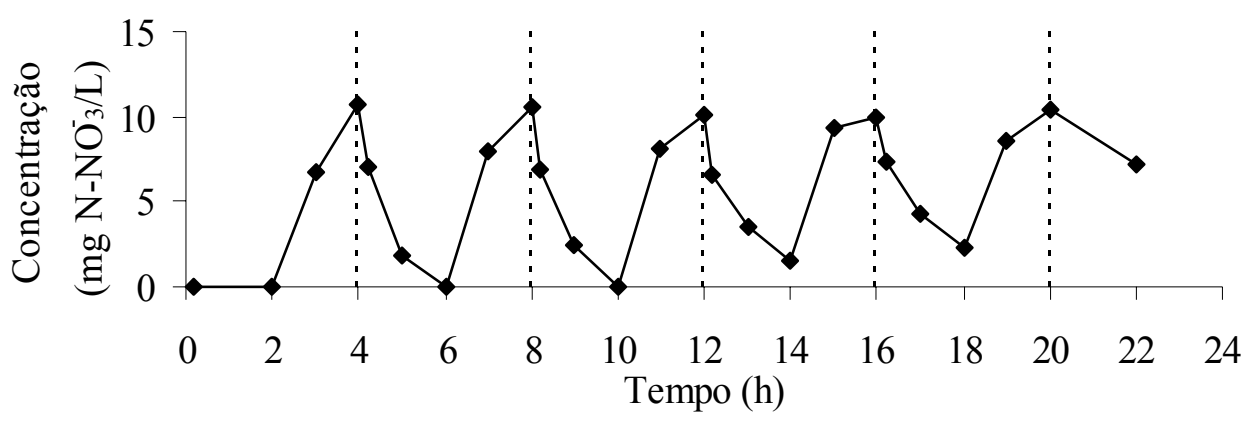

(a)

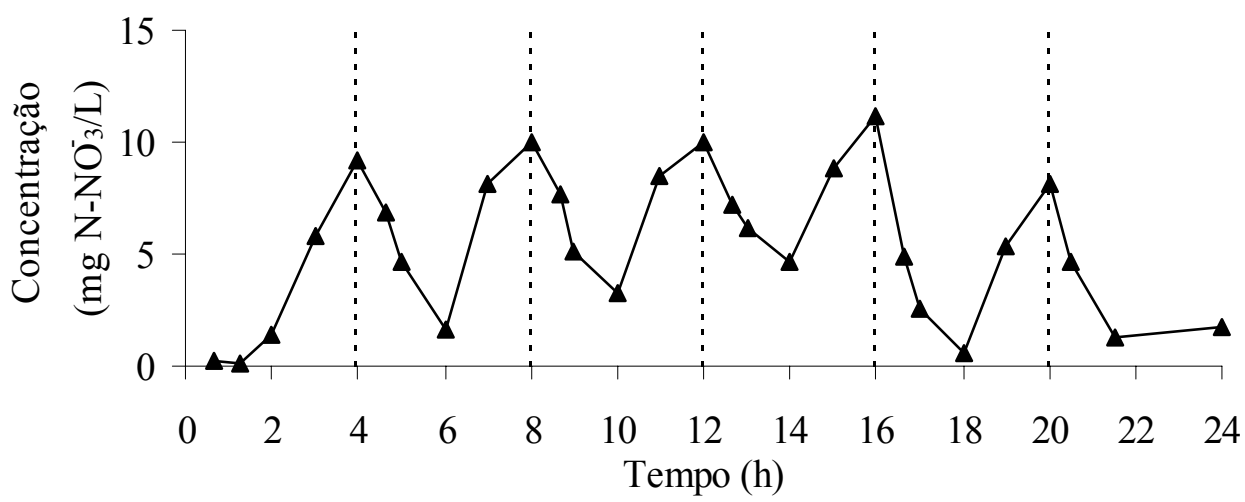

(b)

Figura 5.5 - Variação temporal das concentrações de nitrato durante condição operacional de $125 \mathrm{mg} \mathrm{N} / \mathrm{L}$ em concentração média de OD de 2 mg O $2 / \mathrm{L}$ : (a) aos 84dias; (b) aos 180 dias de experimento.

Durante o período aeróbio, quando se atingiam valores muito altos de concentração de OD (4 a 6 mg $\mathrm{O}_{2} / \mathrm{L}$ ), a extensão do período anóxico e a quantidade de fonte de carbono não foram suficientes para desnitrificar todo o nitrato produzido. Esses valores altos ocorriam, porque a regulagem da vazão de ar era feita manualmente através da abertura ou fechamento das válvulas de agulha (conforme descrito no item 4.2) e depois era conferido se a vazão de ar resultava na faixa de concentração de OD desejada. Portanto, o ajuste era feito manualmente e sujeito a erros.

Por outro lado, nas concentrações de OD entre 1 e $2 \mathrm{mg} \mathrm{O}_{2} / \mathrm{L}$, sempre ocorreu desnitrificação do nitrato produzido no período aeróbio anterior. Isso também justifica porque o reator apresentou bom desempenho em termos de nitrificação e desnitrificação na concentração de $\mathrm{OD}$ de $1,5 \mathrm{mg} \mathrm{\textrm {O } _ { 2 }} / \mathrm{L}$, como apresentado na Figura 5.6.

Observou-se, na primeira hora, que 50\% do nitrato foi desnitrificado tanto na

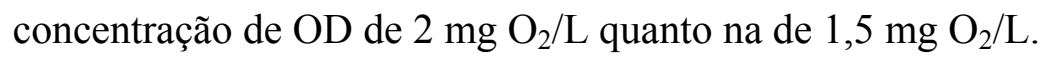




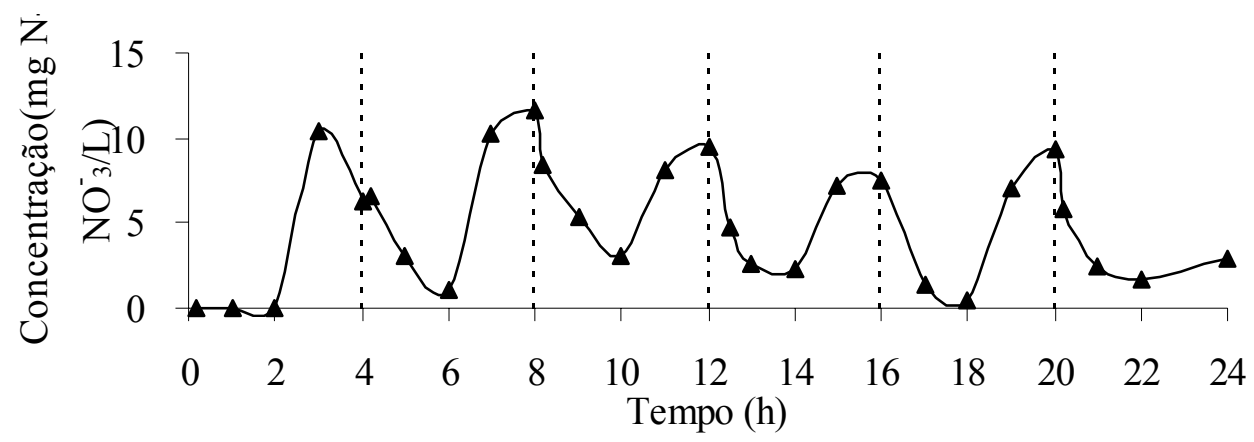

Figura 5.6 - Variação temporal das concentrações de nitrato durante condição operacional de $125 \mathrm{mg} \mathrm{N} / \mathrm{L}$ em concentração média de OD de $1,5 \mathrm{mg} \mathrm{O} \mathrm{O}_{2} / \mathrm{L}$ aos 156 dias de experimento.

Com relação à fonte de carbono escolhida, pode-se considerar que o amido foi consumido durante o processo de nitrificação/desnitrificação, considerando-se que a eficiência de consumo de DQO filtrada foi de 98\% (Tabela 5.3). Esse resultado também implica que não houve acúmulo de carbono no final das fases anóxicas posteriores.

De acordo com Katsogiannis et al. (2003), a fase de enchimento sob condições anóxicas permite que haja a estocagem de compostos de carbono pelos microrganismos e, portanto, pode haver maior disponibilidade de carbono durante as fases anóxicas subseqüentes. Este fato também é corroborado por Tilche et al. (1999) que relataram que houve melhor distribuição de doadores de elétrons, quando da adoção dessa estratégia.

Tabela 5.3 - Eficiências médias de remoção de DQO total e DQO filtrada e relação DQO filtrada/DQO total no efluente, durante a condição operacional de $125 \mathrm{mg} \mathrm{N} / \mathrm{L}$.

\begin{tabular}{lccc}
\hline & DQO filtrada /DQO t & $\begin{array}{c}\text { Eficiência de } \\
\text { remoção DQO total }\end{array}$ & $\begin{array}{c}\text { Eficiência de remoção } \\
\text { DQO filtrada }\end{array}$ \\
\hline OD 2 mg/L & 0,53 & $96 \pm 3(86-100)$ & $98 \pm 1(96-100)$ \\
OD 1,5 mg/L & 0,36 & $95 \pm 3(91-98)$ & $98 \pm 1(96-99)$ \\
OD 2 mg/L & 0,28 & $93 \pm 11(57-100)$ & $98 \pm 1(89-100)$ \\
\hline
\end{tabular}

Durante a operação com concentração de OD de $1,5 \mathrm{mg} \mathrm{O}_{2} / \mathrm{L}$, houve muito arraste de biomassa, devido ao elevado crescimento das bactérias filamentosas e conseqüente flotação de parte do lodo com arraste de sólidos junto com o efluente. Nesse caso, como o efluente apresentava sólidos na amostra líquida, procedeu-se à centrifugação do mesmo. Isso mascarou os resultados de DQO, que são apresentados na Tabela 5.3. Quando a relação DQOfiltrada/DQO total no efluente foi de 0,36 , isto significa dizer que aproximadamente $64 \%$ da DQO total era composta de material particulado, o que pode significar uma perda de sólidos no efluente. 


\subsection{2 - Efeito da aeração intermitente}

\subsubsection{1 - Análise pontual - análise da batelada de $24 \mathrm{~h}$.}

O uso de aeração intermitente permite que se controlem as concentrações de ácido nitroso livre e amônia livre, cujas concentrações são influenciadas pelo pH e pela temperatura. $\mathrm{O}$ pH é mantido estável quando a operação é feita alternando-se os períodos anóxicos e aeróbios.

Os valores de $\mathrm{pH}$ na condição operacional de $125 \mathrm{mg}$ N/L durante um ciclo de $24 \mathrm{~h}$ aos 84 dias, 156 dias e 180 dias (Figuras 5.7a, 5.7b e 5.7c) permaneceram dentro da faixa de $\mathrm{pH}$ recomendada por Metcalf e Eddy (1991) (pH entre 7,2 a 9,0 para nitrificação e entre 6,5 a 7,5 para a desnitrificação).

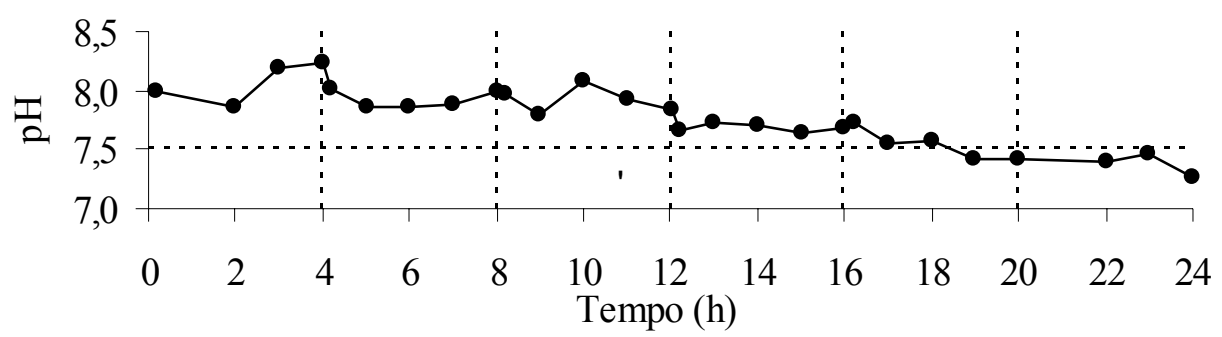

(a)

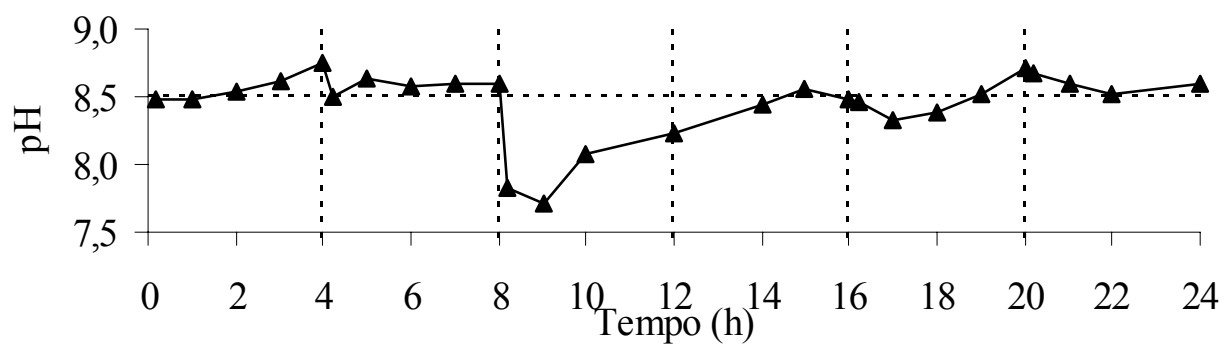

(b)

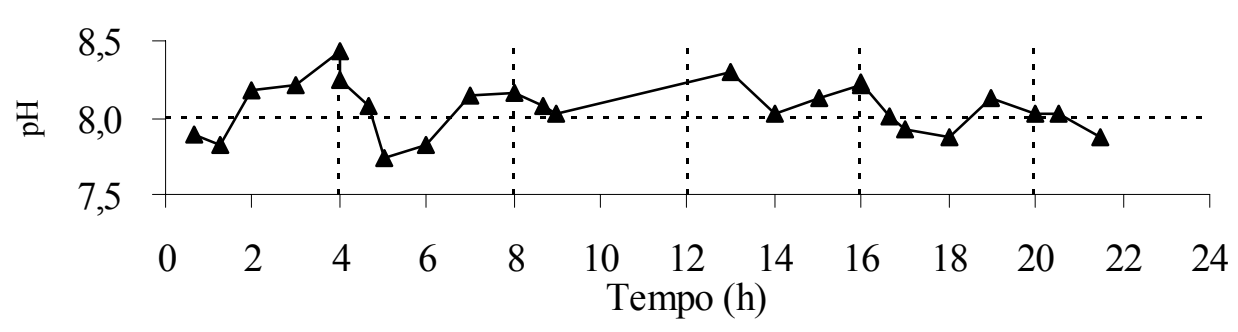

(c)

Figura 5.7 - Variação temporal dos valores de pH durante a condição operacional de $125 \mathrm{mg}$ N/L: (a) aos 84dias em concentração de OD de $2 \mathrm{mg} \mathrm{O} / \mathrm{L}$; (b) aos 156 dias em concentração de OD de $1,5 \mathrm{mg} \mathrm{O}_{2} / \mathrm{L}$; (c) aos 180 dias em concentração de OD de $2 \mathrm{mg} \mathrm{O}_{2} / \mathrm{L}$. 
O comportamento teórico de $\mathrm{pH}$ seria o de decréscimo durante o ciclo aeróbio e aumento durante o período anóxico, padrão esse que não ocorreu, como pode ser observado nas Figuras 5.7a, 5.7b e 5.7c e dados da Tabela 5.4. Porém, esse fato não interferiu na estabilidade do processo. Após a diminuição na concentração de OD para 1,5 $\mathrm{mg} \mathrm{O}_{2} / \mathrm{L}$, o perfil de $\mathrm{pH}$ tem leve acréscimo após os períodos aeróbios, apresentando comportamento mais estável com relação ao valor de $\mathrm{pH}$ efluente, que foi maior ou igual ao do $\mathrm{pH}$ afluente.

Tabela 5.4 - Variação dos valores de pH e potencial redox durante condição operacional de $125 \mathrm{mgN} / \mathrm{L}$ no final de cada período anóxico e aeróbio aos 84 d, $156 \mathrm{~d}$ e

\begin{tabular}{lcccccc}
\hline & \multicolumn{2}{c}{$84 \mathrm{~d}$} & \multicolumn{2}{c}{$156 \mathrm{~d}$} & \multicolumn{2}{c}{$180 \mathrm{~d}$} \\
\cline { 2 - 8 } & $\mathrm{pH}$ & $\begin{array}{c}\text { potencial } \\
\text { redox }\end{array}$ & $\mathrm{pH}$ & $\begin{array}{c}\text { potencial } \\
\text { redox }\end{array}$ & $\mathrm{pH}$ & $\begin{array}{c}\text { potencial } \\
\text { redox }\end{array}$ \\
\hline $\mathrm{pH}$ afluente & 8,2 & & 8,2 & & 8,0 & \\
final anóxico 1 & 7,85 & -259 & 8,54 & -146 & 8,2 & -512 \\
final aeróbio 1 & 8,23 & -109 & 8,75 & +34 & 8,4 & +48 \\
\hline final anóxico 2 & 7,86 & -182 & 8,57 & -77 & 7,8 & -217 \\
final aeróbio 2 & 8,00 & +36 & 8,6 & +31 & 8,2 & +56 \\
\hline final anóxico 3 & 8,08 & -199 & 8,07 & -88 & - & -116 \\
final aeróbio 3 & 7,84 & +40 & 8,24 & +64 & - & +81 \\
\hline final anóxico 4 & 7,71 & -23 & 8,44 & -53 & 8,02 & -46 \\
final aeróbio 4 & 7,69 & +58 & 8,49 & +50 & 8,22 & +89 \\
\hline final anóxico 5 & 7,58 & -118 & 8,39 & -66 & 7,87 & -55 \\
final aeróbio 5 & 7,43 & +74 & 8,71 & +65 & 8,02 & +241 \\
\hline efluente 24h & 7,26 & +40 & 8,59 & +1 & - & -329 \\
\hline
\end{tabular}

A amônia livre pode afetar negativamente a atividade das bactérias oxidantes de nitrito levando ao acúmulo de nitrito (TURK e MAVINIC, 1987 e 1989). A concentração média de N-amoniacal foi de $10 \mathrm{mg} \mathrm{N} / \mathrm{L}$ (Figura 5.4) no início de cada período anóxico. Considerando-se o $\mathrm{pH}$ afluente de 8,0 e a temperatura de $25^{\circ} \mathrm{C}, 6,9 \%$ do amônio estariam na forma não ionizada (como amônia livre), conforme pode ser calculado pela equação (4.1). Portanto, a concentração de $10 \mathrm{mg} \mathrm{N}-\mathrm{NH}^{+}{ }_{4} / \mathrm{L}$ no reator produziu uma concentração de $0,69 \mathrm{mg} \mathrm{N}-\mathrm{NH}_{3} / \mathrm{L}$.

As concentrações inibitórias relatadas em literatura estão na faixa de $0,1 \mathrm{a} 1 \mathrm{mg}$ $\mathrm{N}-\mathrm{NH}_{3} / \mathrm{L}$ de acordo com Anthonisen et al. (1976) e de 1 a $5 \mathrm{mg} \mathrm{N}-\mathrm{NH}_{3} / \mathrm{L}$ de acordo Abeling e Seyfried (1992). Porém, as condições da primeira faixa são para reatores nitrificantes e a segunda faixa compreende os dois processos. Nessa condição 
operacional não houve inibição por amônia livre, principalmente porque as concentrações de amônia livre estão abaixo de $1 \mathrm{mg} \mathrm{N}-\mathrm{NH}_{3} / \mathrm{L}$. Esse comportamento pode ser observado na variação temporal de concentração de amônia livre nas diferentes concentrações de OD apresentado na Figura 5.8.
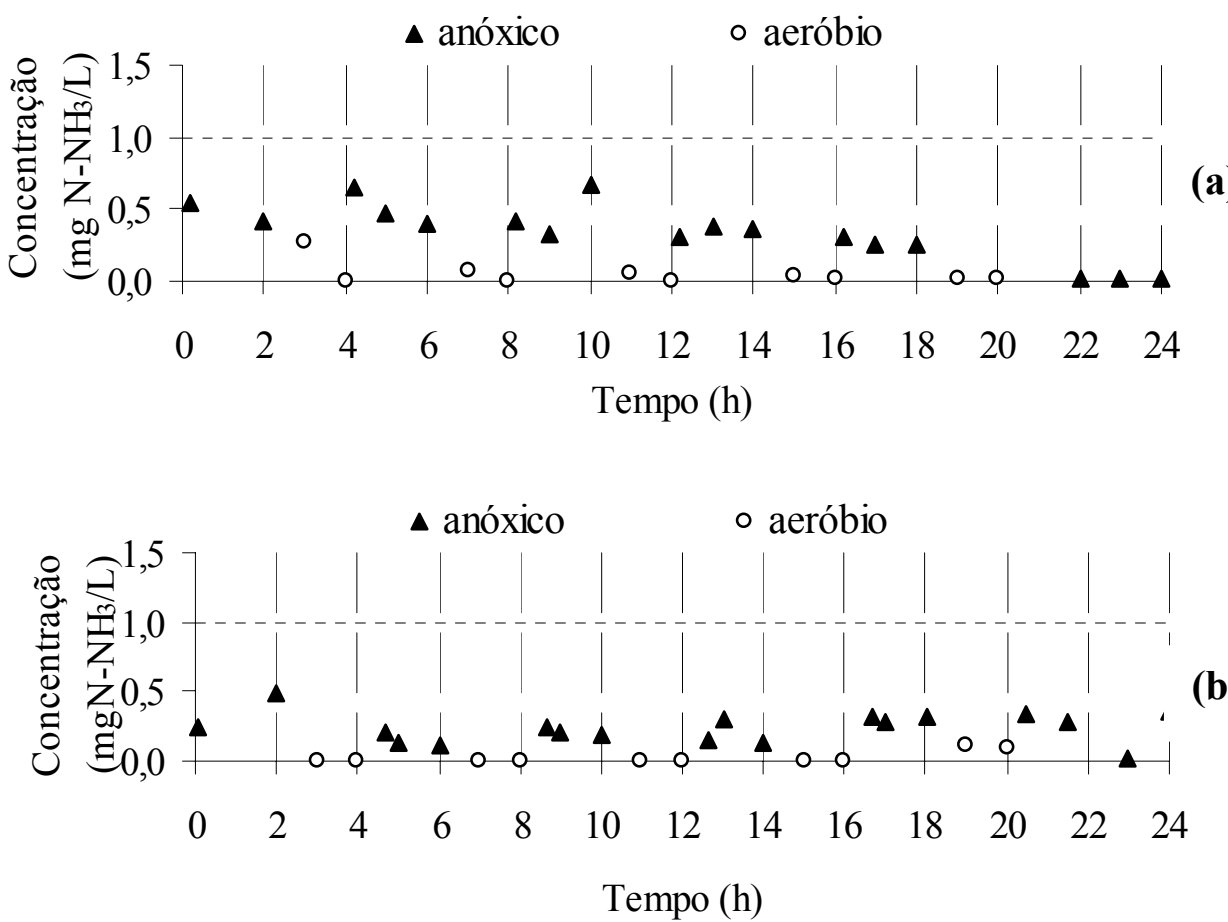

(b)

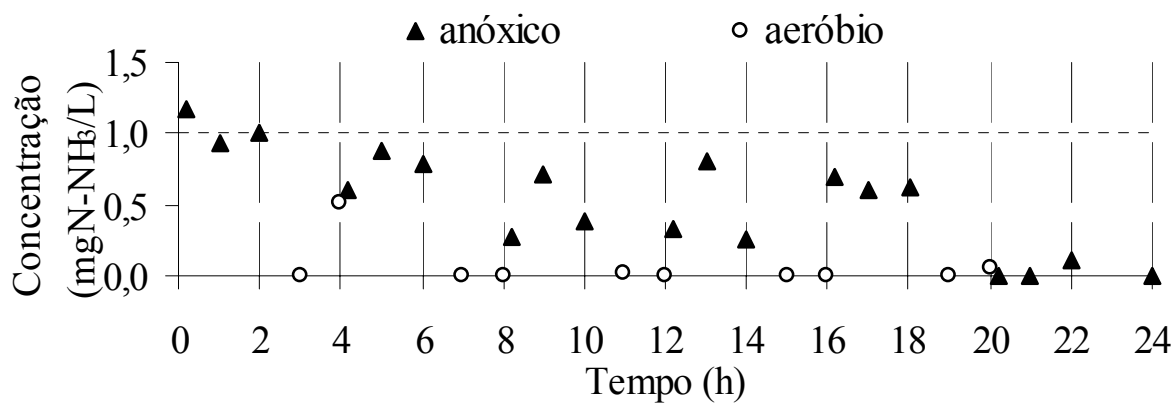

(c)

Figura 5.8 - Variação temporal das concentrações de amônia livre durante a condição operacional de $125 \mathrm{mg} \mathrm{N} / \mathrm{L}$ : (a) aos 84 dias em concentração de OD de $2 \mathrm{mg} \mathrm{O} / 2$; (b) aos 156 dias em concentração de $\mathrm{OD}$ de $1,5 \mathrm{mg} \mathrm{O}_{2} / \mathrm{L}$ e (c) aos 180 dias em concentração de OD de $2 \mathrm{mg}$ $\mathrm{O}_{2} / \mathrm{L}$.

Do mesmo modo, a concentração de amônia livre pode inibir as bactérias oxidantes de $\mathrm{N}$-amoniacal, porém em concentrações mais elevadas comparadas com concentrações inibitórias para as bactérias oxidantes de nitrito. De acordo com Anthonisen et al. (1976), esses microrganismos podem ser inibidos em concentrações de 10 a $150 \mathrm{mg} \mathrm{N}-\mathrm{NH}_{3} / \mathrm{L}$.

Nesse experimento, as concentrações de amônia livre estiveram abaixo do limite 
de inibição para as bactérias oxidantes de $\mathrm{N}$-amoniacal (abaixo de $1 \mathrm{mg} \mathrm{N}-\mathrm{NH}_{3} / \mathrm{L}$ Figuras 5.8a, 5.8b e 5.8c). Na concentração de $\mathrm{OD}$ de $2 \mathrm{mg} \mathrm{O}_{2} / \mathrm{L}$, as concentrações de amônia livre variaram de 0,3 a $0,7 \mathrm{mg} \mathrm{N}-\mathrm{NH}_{3} / \mathrm{L}$ no início dos períodos aeróbios, como pode ser visto nas Figuras 5.8a e 5.8c. Houve a oxidação de $\mathrm{N}$-amoniacal e conseqüente redução da concentração de amônia livre nos períodos aeróbios. Portanto, não houve aumento, ao longo da batelada, da concentração de amônia livre presente no início dos períodos anóxicos. Durante a operação com concentração de $\mathrm{OD}$ de $1,5 \mathrm{mg} \mathrm{O} \mathrm{O}_{2} / \mathrm{L}$, a média das concentrações de amônia livre no final dos períodos anóxicos aproximou-se de $1 \mathrm{mg} \mathrm{N}-\mathrm{NH}_{3} / \mathrm{L}$. Porém não houve inibição da nitritação.

De acordo com a literatura, o acúmulo de nitrito em filtros foi favorecido quando as relações $\mathrm{OD} / \mathrm{NH}_{3}$ e $\mathrm{OD} / \mathrm{NH}^{+}{ }_{4}$ foram menores que 10 e 1 , respectivamente (ÇEÇEN, 1996). Essas relações implicam que a concentração de oxigênio poderia agir como fator limitante. Nesse experimento, considerando-se a concentração média de $10 \mathrm{mg}$ N$\mathrm{NH}_{4}^{+} / \mathrm{L}$ e concentração média de OD de $2 \mathrm{mg} \mathrm{O} / \mathrm{L}$, as relações de $\mathrm{OD} / \mathrm{NH}_{3}=3$ e $\mathrm{OD} / \mathrm{NH}_{4}^{+}=0,2$, não foram fatores que favoreceram o acúmulo de nitrito, como no caso de sistemas em leito fixo.

Considera-se também, que ácido nitroso livre $\left(\mathrm{HNO}_{2}\right)$ pode inibir a desnitrificação. Em estudo de Abeling e Seyfried (1992) ocorreu inibição da desnitrificação com concentrações de $0,13 \mathrm{mg} \mathrm{N}-\mathrm{HNO}_{2} / \mathrm{L}$, equivalentes em $\mathrm{pH}$ 6,8 ao

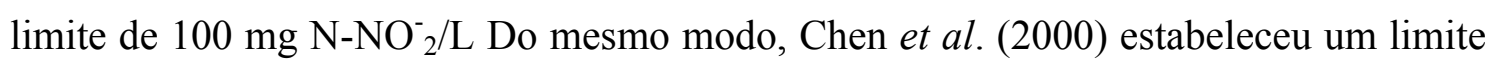
de $2000 \mathrm{mg} \mathrm{N}-\mathrm{NO}_{2}^{-} / \mathrm{L}$, equivalente a 0,16 a $0,02 \mathrm{mg} \mathrm{N}-\mathrm{HNO}_{2} / \mathrm{L}$. No experimento, as concentrações de ácido nitroso livre não ultrapassaram valores de $0,004 \mathrm{mg} \mathrm{N}-\mathrm{HNO}_{2} / \mathrm{L}$.

\subsubsection{2 - Comportamento do pH e da alcalinidade}

O controle do $\mathrm{pH}$ ocorre através do balanço da alcalinidade, que é consumida durante a nitrificação, e que é parcialmente devolvida durante a desnitrificação no período anóxico. Os valores de $\mathrm{pH}$ no afluente e efluente do reator podem ser observados na Figura 5.9 e Tabela 5.5. 


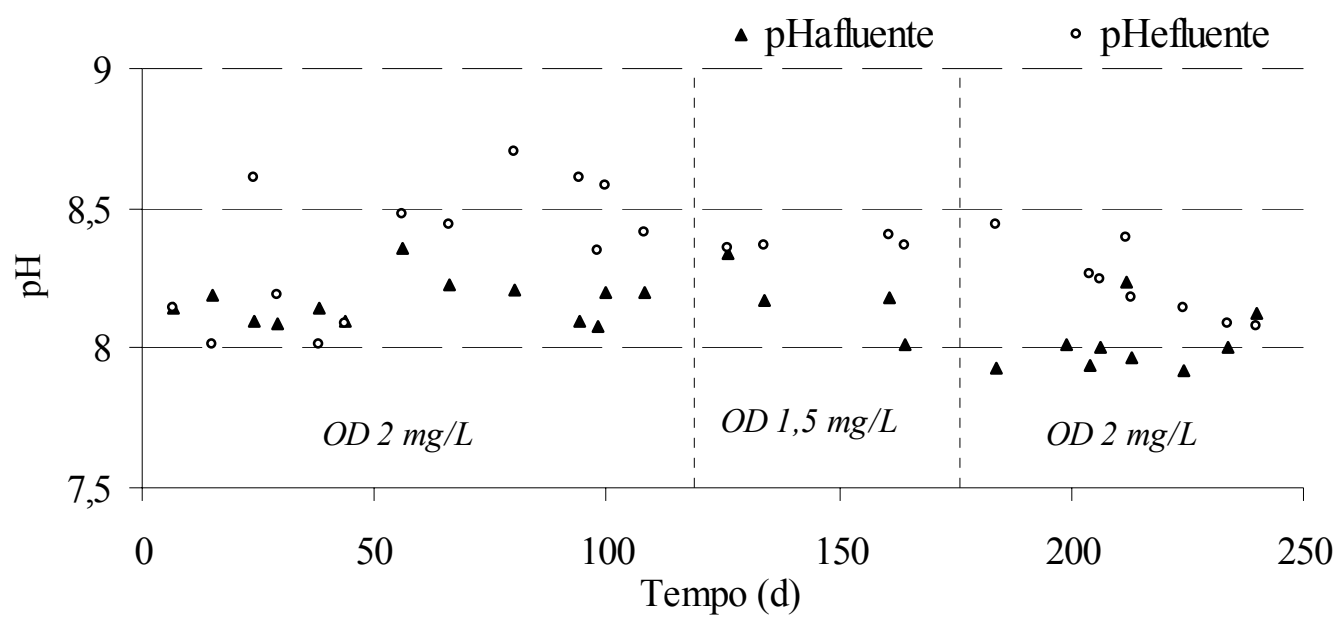

Figura 5.9 - Variação do pH afluente e efluente durante condição operacional de $125 \mathrm{mg} \mathrm{N} / \mathrm{L}$ e sob duas condições de OD.

No processo de remoção de nitrogênio, é interessante que se mantenha o $\mathrm{pH}$ acima de 6,5 , pois é a faixa na qual a nitrificação é mais eficiente. Os valores mostrados na Figura 5.9, obtidos ao longo do experimento, indicam que houve ganho de alcalinidade, demonstrado pelo valor de $\mathrm{pH}$ do efluente acima do $\mathrm{pH}$ do afluente. No experimento nitrificante de Carrera et al. (2004) houve acúmulo de amônio ocasionado pela falta de alcalinidade, levando à inibição por amônia livre. Para reverter essa inibição, os autores diminuíram a taxa de carregamento de nitrogênio e fizeram controle de $\mathrm{pH}$ em 7,5. Çeçen e Gonenç (1995) relataram que há ganho de $3,85 \mathrm{mg} \mathrm{CaCO}_{3}^{-}$por mg de $\mathrm{N}^{-\mathrm{NO}_{2}}{ }^{-}$oxidado na desnitrificação.

As concentrações médias de $\mathrm{AB}$ no efluente de $552 \mathrm{mg} \mathrm{CaCO}_{3}^{-} / \mathrm{L}$ em OD de 2 $\mathrm{mg} \mathrm{O}_{2} / \mathrm{L}$ e de $627 \mathrm{mg} \mathrm{CaCO}_{3}^{-} / \mathrm{L}$, em OD de $1,5 \mathrm{mg} \mathrm{O}_{2} / \mathrm{L}$, que foram $55 \%$ e $65 \%$ da $\mathrm{AB}$ no afluente, indicaram que o processo de desnitrificação conseguiu devolver a alcalinidade gasta em cada período aeróbio.

Tabela 5.5 - Resultados de $\mathrm{pH}$ e $\mathrm{AB}\left(\mathrm{mg} \mathrm{CaCO}_{3}^{-} / \mathrm{L}\right)$ durante a condição operacional de $125 \mathrm{mg}$ $\mathrm{N} / \mathrm{L}$ com diferentes concentrações de OD.

\begin{tabular}{lllll}
\hline \multicolumn{2}{c}{ Afluente } & \multicolumn{2}{l}{ Efluente } \\
\hline $\begin{array}{l}\mathrm{OD} \\
(\mathrm{mg} / \mathrm{L})\end{array}$ & $\mathrm{pH}$ & $\mathrm{AB}\left(\mathrm{mg} / \mathrm{L} \mathrm{CaCO}_{3}^{-}\right)$ & $\mathrm{pH}$ & $\begin{array}{l}\mathrm{AB}(\mathrm{mg} / \mathrm{L} \mathrm{CaCO} \\
3\end{array}$ \\
\hline 2 & $8,2 \pm 1(7,9-8,4)$ & $995 \pm 83(836-1138)$ & $8,4 \pm 1(8,0-8,7)$ & $552 \pm 102(318-711)$ \\
1,5 & $8,2 \pm 1(8,0-8,3)$ & $971 \pm 167(725-1089)$ & $8,4 \pm 1(8,3-8,4))$ & $627 \pm 64(554-693)$ \\
2 & $8 \pm 1(7,9-8,2)$ & $1063 \pm 620(980-1187)$ & $8,4 \pm 1,1(7,2-8,4)$ & $727 \pm 146(589-$ \\
& & & & $1042)$ \\
\hline
\end{tabular}

Os valores de alcalinidade a bicarbonato no afluente e efluente podem ser observados na Figura 5.10. 


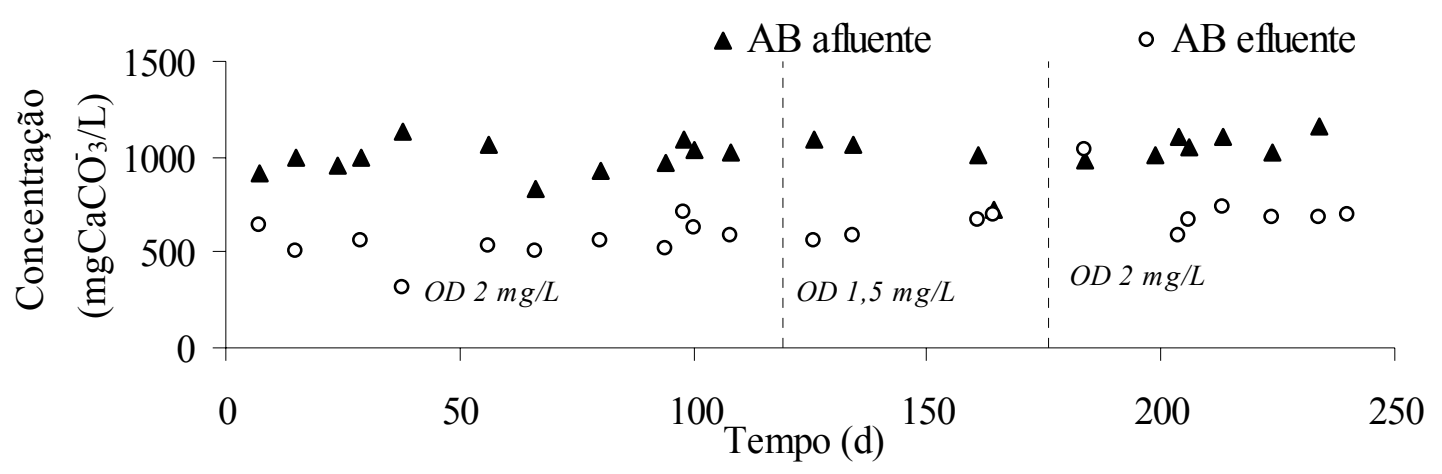

Figura 5.10 - Variação da alcalinidade a bicarbonato (AB) afluente e efluente durante a condição operacional de $125 \mathrm{mg} \mathrm{N} / \mathrm{L}$ e sob duas condições de OD.

\subsection{3 - Potencial redox e oxigênio dissolvido}

O perfil temporal de potencial redox pode indicar pontos que estão correlacionados diretamente com mudanças na atividade química e biológica do sistema (WAREHAM et al., 1993). Ra et al. (2000) e Pedie et al. (1990) não consideram os valores absolutos de potencial redox, pois estes são fortemente correlacionados com reações biológicas. A variação temporal dos valores de potencial redox, em alguns casos, pode ser utilizada para determinar ou controlar os períodos de aeração e não aeração, por apresentar pontos de inflexão característicos, como relatado por vários autores (WAREHAM et al., 1993; HAO e HUANG, 1996; SASAKI et al., 1991). No texto da tese, os valores de potencial redox encontram-se em relativos milivolts (RmV).

Os valores de potencial redox, apresentados na Figura 5.11, eram muito baixos inicialmente (próximo de valores considerados anaeróbios $-260 \mathrm{RmV}$ ) devido ao período anterior de $2 \mathrm{~h}$ (de sedimentação) antes do descarte. Porém, ao iniciar a aeração no $\mathrm{t}=2 \mathrm{~h}$, notou-se que o reator atingiu valores positivos de potencial redox. No período anóxico subseqüente, devido à aeração intermitente, os valores de potencial redox atingidos não foram tão baixos, acima de $-150 \mathrm{RmV}$. Somente no último período anóxico ( $\mathrm{t}=20$ às $22 \mathrm{~h}$ ), os valores de potencial redox tornaram-se mais altos, variando de -28 a $-101 \mathrm{RmV}$. Os valores de potencial redox nos períodos aeróbios não ultrapassaram $+80 \mathrm{RmV}$. A partir do segundo período aeróbio $(\mathrm{t}=6 \mathrm{at}=8 \mathrm{~h})$, observou-se que, durante a primeira hora, em que as duas válvulas de ar permanecem abertas, o potencial redox ainda estava com valores negativos, porém crescentes. Quando a concentração de OD atingiu o valor controle de $2 \mathrm{mg} \mathrm{O}_{2} / \mathrm{L}$ (quando uma das válvulas de 
ar é desligada para manter a concentração de OD nesse valor), os valores de potencial atingiram um patamar de $+35 \pm 1,2 \mathrm{RmV}$ no segundo período aeróbio, com valores crescentes a cada período aeróbio, atingindo $+77 \pm 2 \mathrm{RmV}$ no quarto período aeróbio $(\mathrm{t}=18$ a $\mathrm{t}=20 \mathrm{~h})$.

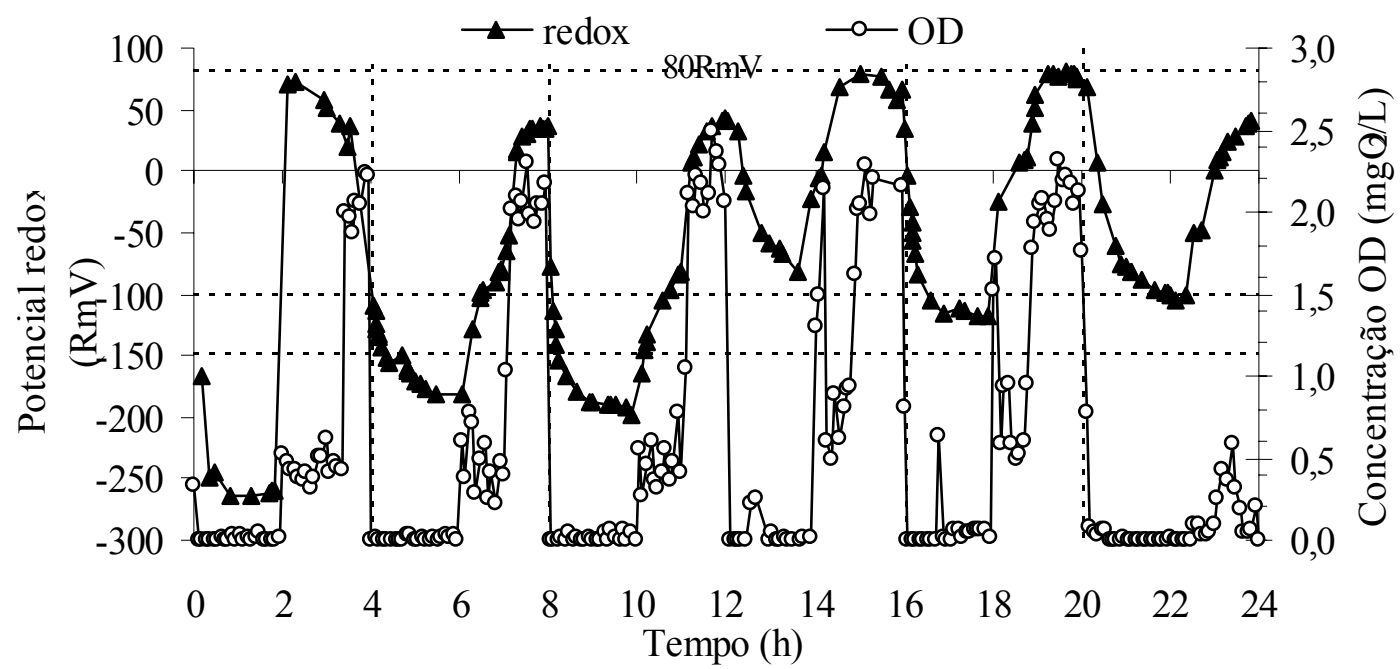

Figura 5.11 - Variação temporal dos valores de potencial redox e concentrações de OD durante a condição operacional de $125 \mathrm{mg} \mathrm{N} / \mathrm{L}$ aos 84 dias.

Segundo Li e Bishop (2002), como os valores de potencial redox correlacionamse com substâncias como enzimas, vitaminas e muitos processos biológicos, do mesmo modo, os valores de potencial redox podem ser relacionados com as mudanças de concentração de OD (consumo e ausência de oxigênio), como pode ser observado nas Figuras 5.11 e 5.12 .

Os valores de potencial redox nos períodos aeróbios não ultrapassaram +90 $\mathrm{RmV}$ durante os três primeiros períodos, atingindo valores próximos de $+200 \mathrm{RmV}$ durante o quarto período aeróbio $(\mathrm{t}=21 \mathrm{~h})$. Comparando a Figura $5.11 \mathrm{com}$ a Figura 5.12, tanto nos períodos anóxicos quanto nos períodos aeróbios, os valores de potencial redox foram mais altos. O patamar do segundo período aeróbio atingiu $+49 \pm 8,5 \mathrm{RmV}$ e do quarto período foi em $+242 \pm 0,9 \mathrm{RmV}$, demonstrando novamente que não há um valor absoluto de potencial redox controle a se considerar.

Quando os períodos aeróbios iniciavam com os aeradores ligados, notou-se que os valores de potencial redox mudavam rapidamente a tendência, apontando para valores crescentes, mostrando mudança muito mais rápida que nos valores de concentração de OD, como pode ser visto nas Figuras 5.11 e 5.12. Essa afirmativa concorda com o relatado por Holman e Wareham (2003) de que as medidas de potencial 
redox incorporam medições mais precisas em zona não aerada ou com baixa concentração de oxigênio do que medidas de concentração de oxigênio dissolvido.

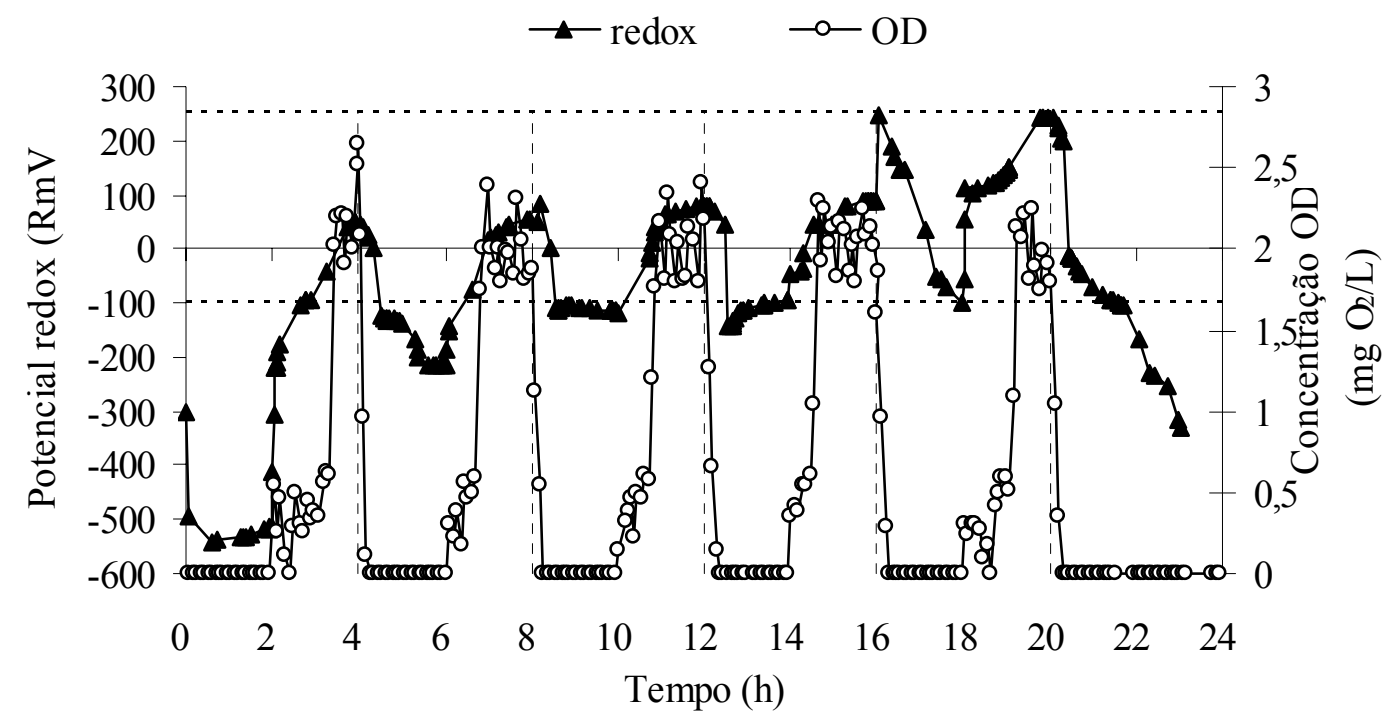

Figura 5.12 - Variação temporal dos valores de potencial redox e concentrações de OD durante a condição operacional de $125 \mathrm{mg} \mathrm{N} / \mathrm{L}$ aos 180 dias.

Nos períodos anóxicos seguintes, os valores de potencial redox decresciam, atingindo um patamar. Essa alternância de valores foi relatada por vários autores e é considerada como comportamento inerente a sistemas com aeração intermitente (WAREHAM et al., 1993, RA et al., 2000, VILLAVERDE et al., 2000)

\subsection{4 - Perfil temporal de um ciclo anóxico/aeróbio}

Realizou-se ensaio de $4 \mathrm{~h}$, com amostras retiradas a cada 15 minutos com a finalidade de se tentar estabelecer relações mais detalhadas entre as variáveis envolvidas: potencial redox, oxigênio dissolvido e concentração de nitrato.

Com relação à variação temporal de potencial redox comparada com a variação temporal das concentrações de OD, que pode ser observada na Figura 5.13a, a mudança de fase anóxica para fase aeróbia é acompanhada pelas duas variáveis. A mudança de concentração de OD pode ser ajustada com as mudanças da curva de potencial redox.

$\mathrm{Na}$ Figura 5.13b, a variação temporal dos valores de potencial redox é comparada à variação temporal das concentrações de nitrato durante o terceiro ciclo anóxico/aeróbio. A mudança das concentrações de nitrato pode ser acompanhada pelo potencial redox. A variação temporal de potencial redox é concordante com as 
concentrações de nitrato, porque ele está diretamente relacionado com a composição iônica do meio. No período aeróbio, quando a concentração de OD atingiu o valor controle de $2 \mathrm{mg} \mathrm{O}_{2} / \mathrm{L}$, os valores de potencial redox atingiram patamar $(133 \pm 3 \mathrm{RmV}$,

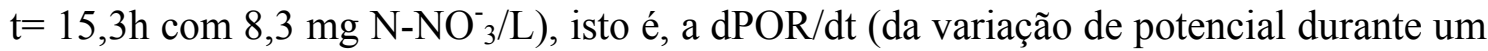
determinado tempo) era constante.

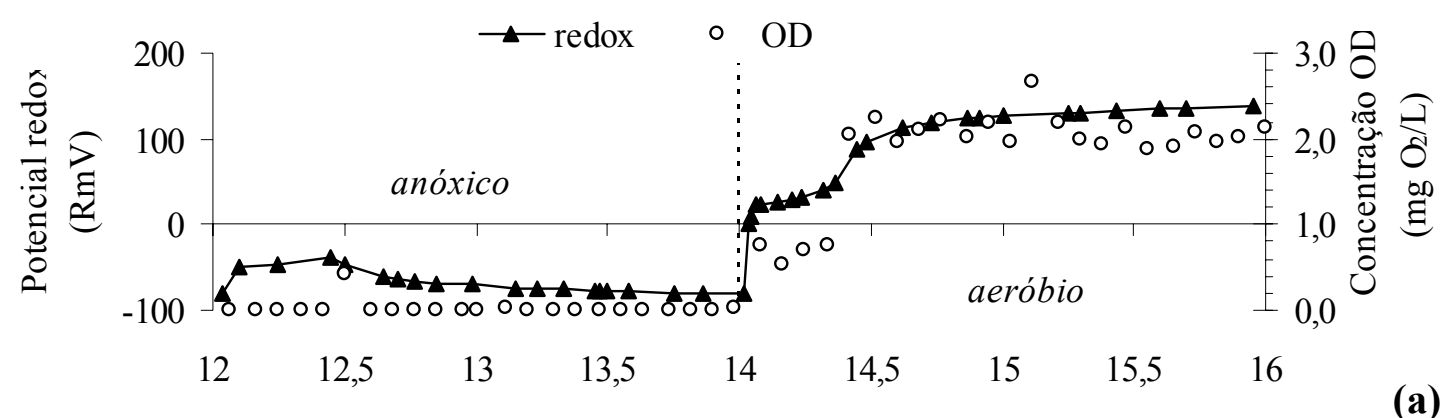

Tempo (h)
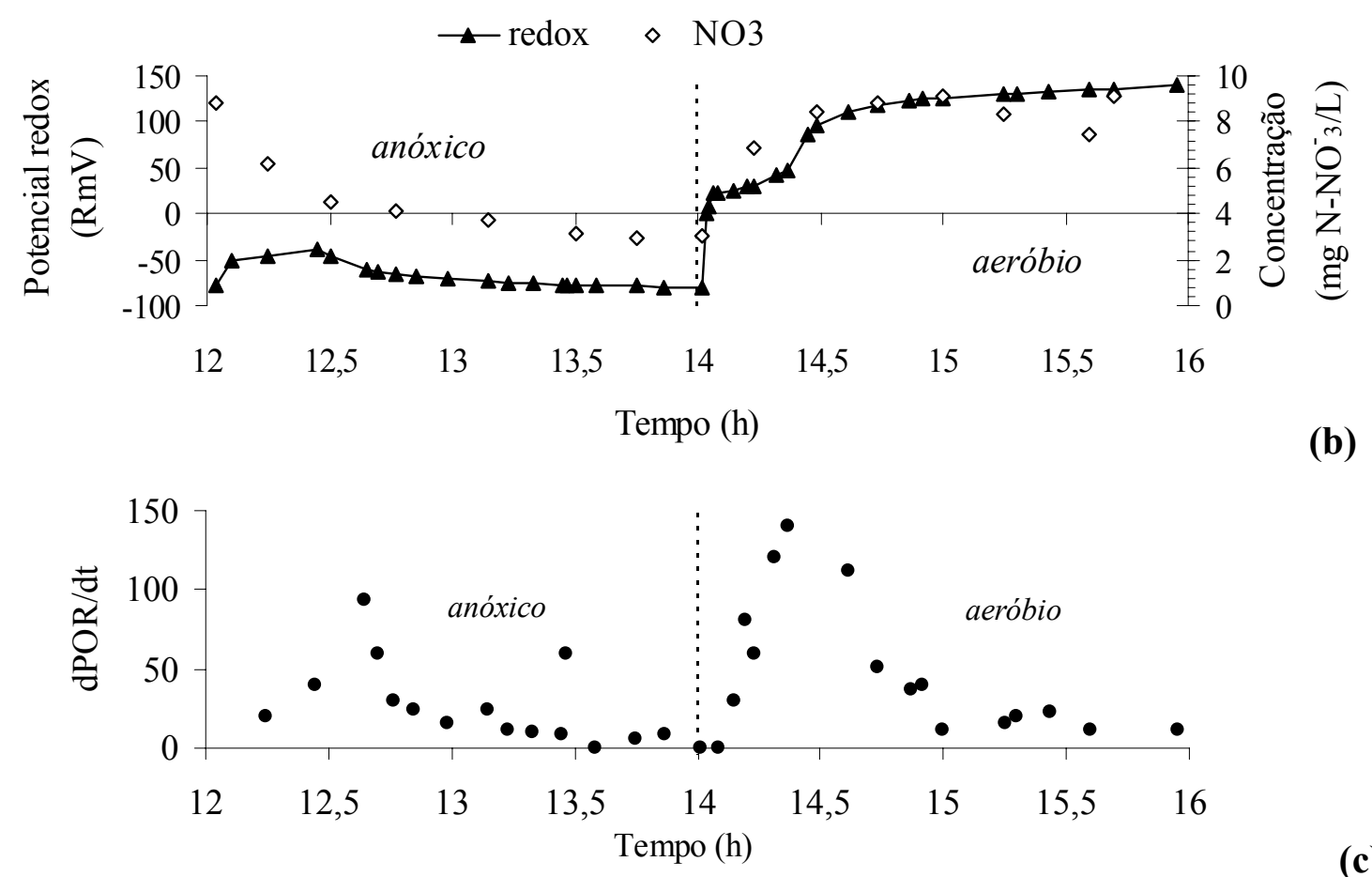

(c)

Figura 5.13 - Variação temporal dos parâmetros durante um ciclo anóxico/ aeróbio de $4 \mathrm{n}$ durante a condição operacional de $125 \mathrm{mg} \mathrm{N} / \mathrm{L}$ em concentração média de OD de $2 \mathrm{mg} \mathrm{O}_{2} / \mathrm{L}$ aos $71 \mathrm{~d}$ de experimento: (a) potencial redox com concentrações de OD; (b) potencial redox com concentrações de nitrato; (c) variação do potencial redox com o tempo (dPOR/dt).

$\mathrm{Na}$ concentração média de OD de $1,5 \mathrm{mg} \mathrm{O}_{2} / \mathrm{L}$ na fase aeróbia, as concentrações de OD e nitrato ajustam-se bem às mudanças nos valores de potencial redox (Figuras $5.14 \mathrm{a}$ e $5.14 \mathrm{~b})$. 


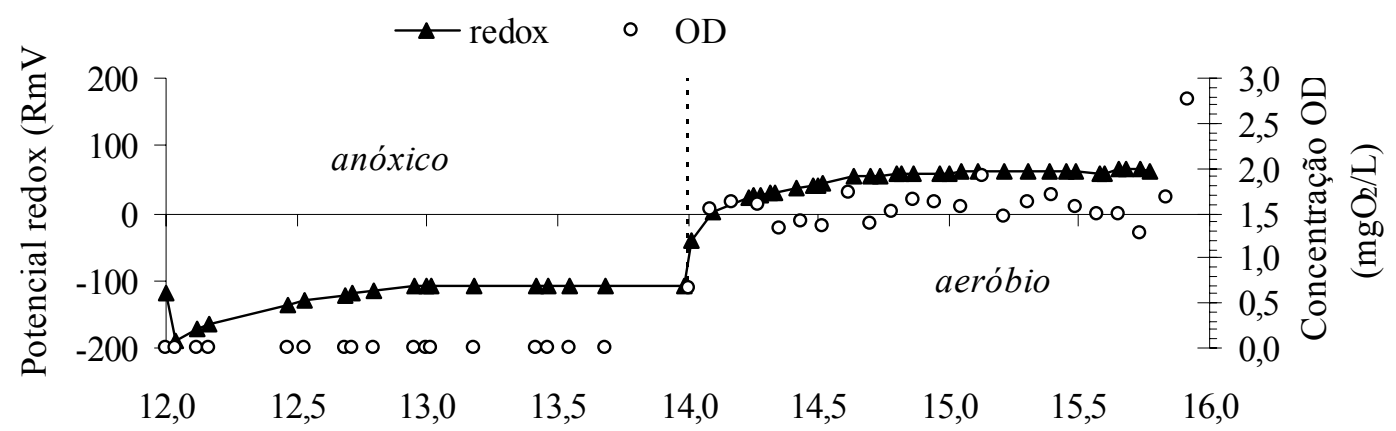

Tempo (h)

(a)

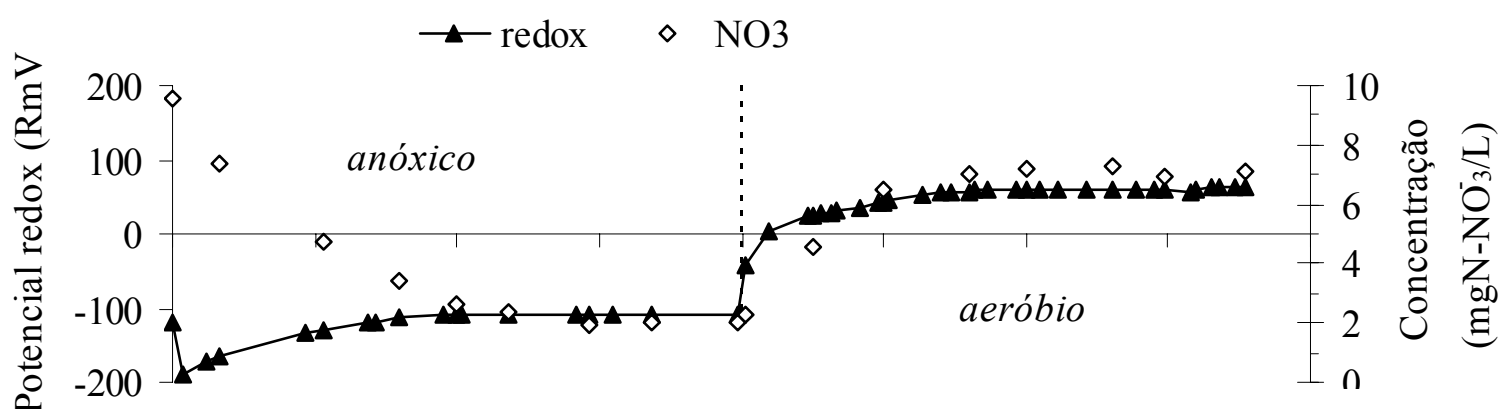

$12,0 \quad 12,5 \quad 13,0 \quad 13,5 \quad 14,0 \quad 14,5 \quad 15,0 \quad 15,5 \quad 16,1$

(b)

Tempo (h)

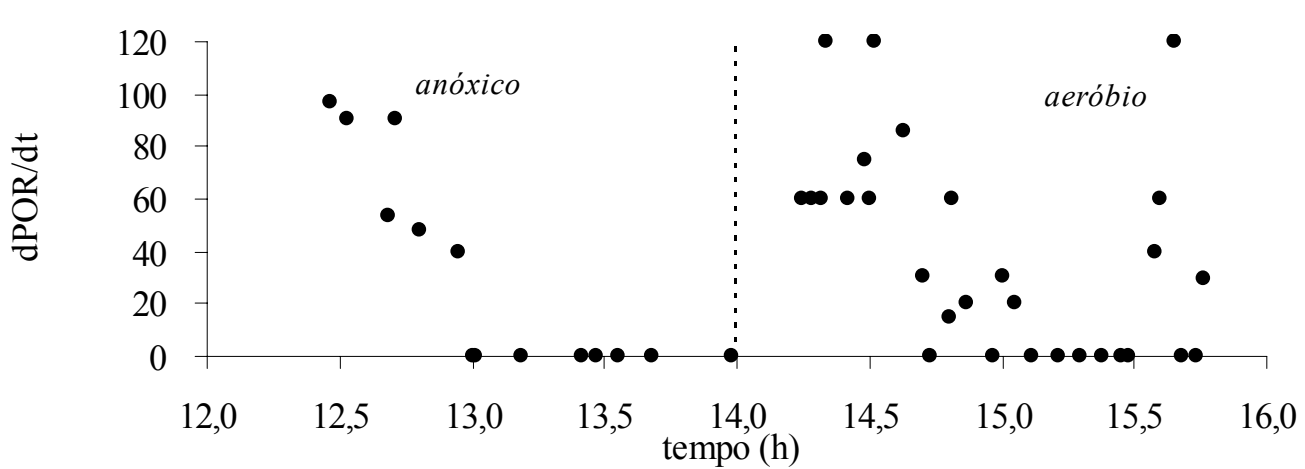

(c)

Figura 5.14 - Variação temporal dos parâmetros durante um ciclo anóxico/aeróbio de $4 \mathrm{~h}$

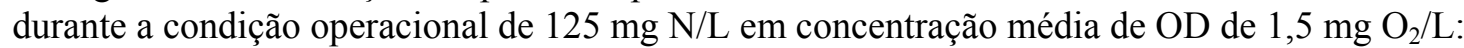

(a) potencial redox com concentrações de OD; (b) potencial redox com concentrações de nitrato; (c) variação do potencial redox com o tempo (dPOR/dt).

Observando-se as Figuras 5.13b, notou-se que, no tempo de 13,5h, todo o nitrato foi consumido quando o potencial redox atingiu patamar de estabilidade, em valor de -

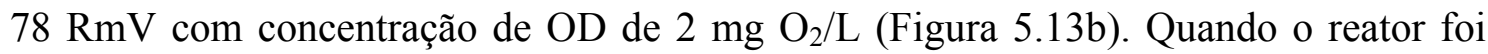
operado com a concentração de OD de $1,5 \mathrm{mg} \mathrm{O}_{2} / \mathrm{L}$ na fase aerada, quase todo o nitrato foi removido quando o potencial redox atingiu o valor de $-108 \mathrm{RmV}$ (Figura 5.14b).

Nos períodos aeróbios com concentração média de OD de 1,5 mg $\mathrm{O}_{2} / \mathrm{L}$ (Figura 5.14), no $\mathrm{t}=15,1 \mathrm{~h}$, a dPOR/dt foi igual a zero e a concentração de nitrato foi de $7,3 \mathrm{mg}$ 


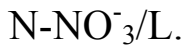

O ensaio de ciclo anóxico/aeróbio, considerando que todos os cinco ciclos apresentam comportamentos similares, demonstrou que, para concentração de nitrogênio amoniacal afluente de $125 \mathrm{mg} \mathrm{N} / \mathrm{L}$ e concentração média de OD de $2 \mathrm{mg}$ $\mathrm{O}_{2} / \mathrm{L}$, o ciclo anóxico/aeróbio de $1,5 \mathrm{~h} / 1,5 \mathrm{~h}$ seria suficiente para a remoção de nitrogênio. Por outro lado, para a concentração média de $\mathrm{OD}$ de $1,5 \mathrm{mg} \mathrm{O}_{2} / \mathrm{L}$, seria suficiente uma duração do período aeróbio menor que 1,5h.

\subsection{5 - Velocidade de desnitrificação via nitrito e via nitrato}

As velocidades de desnitrificação via nitrito e via nitrato foram estimadas através da produção de $\mathrm{N}_{2} \mathrm{O}$, em ensaio específico. Para esse ensaio, retirou-se lodo durante operação com condição operacional de N-amoniacal no afluente de $125 \mathrm{mg} \mathrm{N} / \mathrm{L}$ $\mathrm{Na}$ Figura 5.15, estão apresentadas as produções acumuladas de $\mathrm{N}_{2} \mathrm{O}$ no Reator 1 e Reator 2, utilizando-se nitrato e nitrito como aceptores terminais de elétrons e amido como doador de elétrons. Os cálculos e os ajustes para a obtenção da produção acumulada de $\mathrm{N}_{2} \mathrm{O}$ encontram-se no Apêndice.

Observa-se que a velocidade de desnitrificação no reator alimentado com nitrito (R2) foi de $0,22 \mathrm{~g} \mathrm{~N} / \mathrm{g} \mathrm{SSV.d}$, semelhante à velocidade via nitrato (R1), que foi de 0,28 g N/g SSV.d. Nesse caso, a diferença na velocidade de desnitrificação via nitrito e via nitrato esteve abaixo dos valores encontrados na literatura. Estudos de Abeling e Seyfried (1992) relataram velocidade de desnitrificação via nitrito como o dobro da velocidade de desnitrificação via nitrato. Outros autores listados no Quadro 3.6 também relataram maior velocidade de desnitrificação via nitrito.

A velocidade de desnitrificação depende da concentração de nitrato ou nitrito, da biomassa ativa, do carbono orgânico e da configuração do reator. Os doadores de elétrons podem ser compostos orgânicos (etanol, metanol, acetato, formiato, glicose, matéria orgânica na água residuária), compostos reduzidos de enxofre e de ferro ou hidrogênio molecular (MATEJU et al., 1992). 
(a) Reator 1

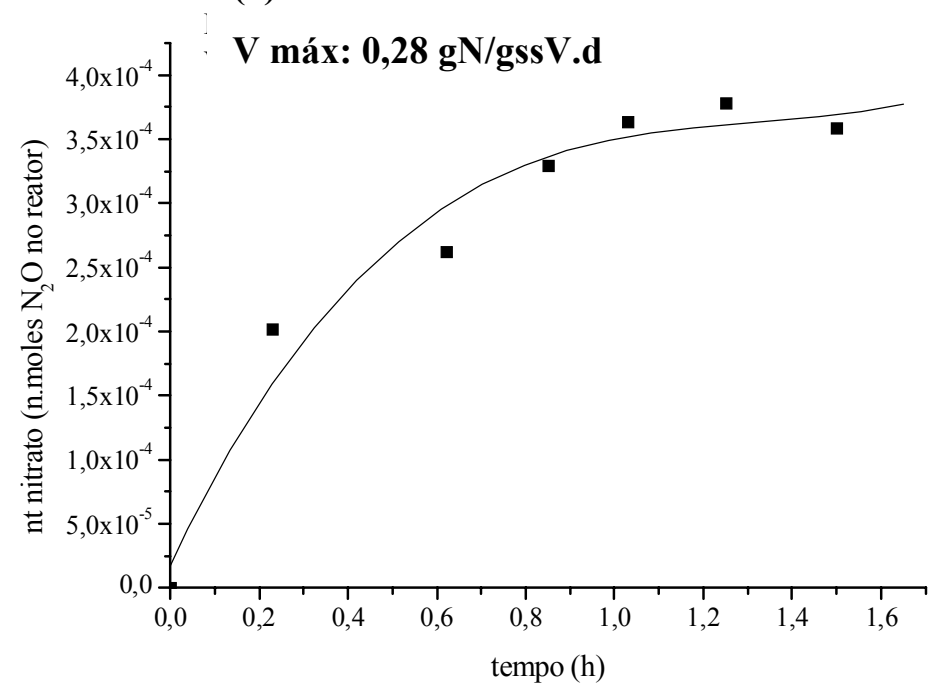

(a)

(a) Reator 2

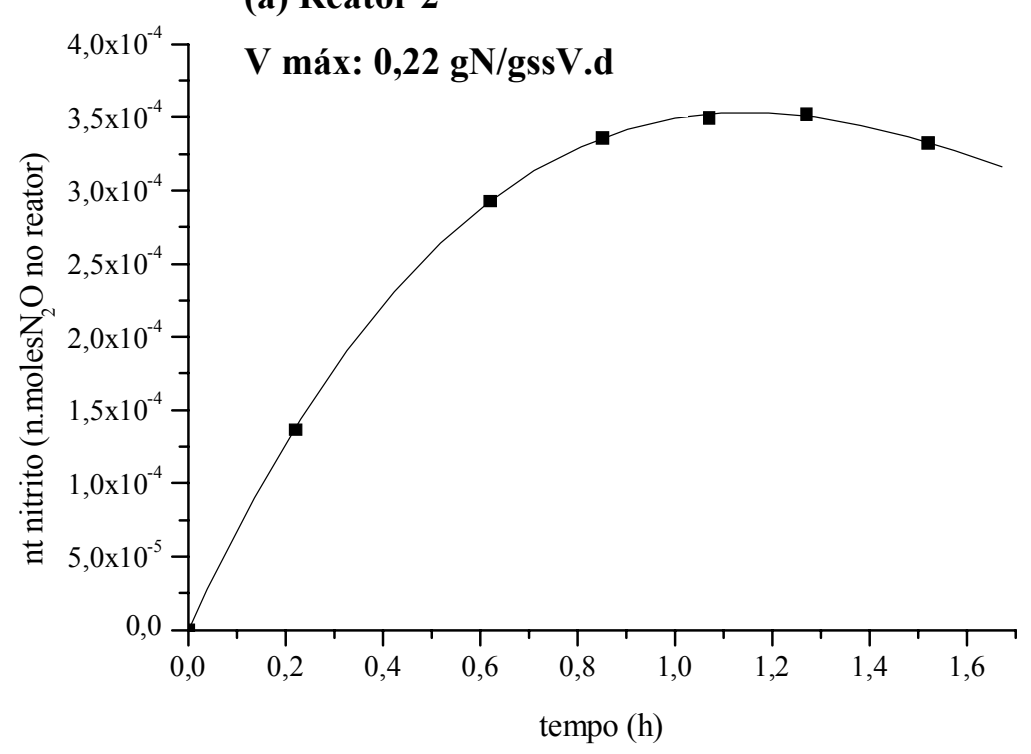

(b)

Figura 5.15 - Produção acumulada de $\mathrm{N}_{2} \mathrm{O}$ ao longo do tempo nos reatores.

(a) reator R1 - nitrato e (b) R2 - nitrito.

Mateju et al. (1992) recomendaram escolha de substrato não fermentável, como o acetato, por ser mais seletivo para atividade respiratória (isto é, desnitrificação), além de minimizar produção de biomassa. Recomenda-se a escolha adequada de relação carbono/nitrogênio, além de formas de carbono mais facilmente degradáveis. Quanto mais biodegradável, mais rápida é a velocidade de desnitrificação. Aesoy et al. (1998) ainda acrescentam que na escolha da fonte de carbono, devem ser consideradas: custo, velocidade de desnitrificação, produção de lodo, estabilidade e segurança para manejo e estoque, teor de compostos tóxicos, etc. 
Tam et al. (1994) demonstraram que a adição de substrato prontamente biodegradável como acetato de sódio melhorou significativamente a eficiência de remoção, quando comparado com metanol e glicose. Aesoy et al. (1998) afirmam que a disponibilidade de matéria orgânica prontamente biodegradável resulta nas mais altas velocidades de desnitrificação.

Desse modo, ao considerar as escolhas das fontes de carbono utilizadas nos ensaios, possivelmente o uso de amido no reator original tenha selecionado maior diversidade de organismos, o que pode ter acarretado um menor número de desnitrificantes durante o ensaio. Mohnseni-Bandpi e Elliott (1998) postularam que a complexidade dos substratos pode desacelerar o processo de desnitrificação e que uma relação $\mathrm{C} / \mathrm{N}$ alta de ácido acético pode ter favorecido a microbiota adaptada a esse substrato, considerando que a biomassa usada no ensaio provinha de reator tratando efluente de reator anaeróbio.

As velocidades de desnitrificação via nitrato de Marchetto et al. (2003), com uso de diferentes fontes de carbono, como ácido acético, metanol, esgoto doméstico, glicose e esgoto sintético, variaram de 0,25 a 0,39 g N/gSTV.d. Os autores obtiveram velocidades mais rápidas com ácido acético e metanol e concluíram que a eficiência de remoção de $\mathrm{N}$ deveu-se aos valores favoráveis de balanço energético de formação e degradação dos compostos envolvidos no processo.

Os resultados de velocidade de desnitrificação nesse experimento pelas duas vias (nitrato e nitrito) foram muito semelhantes e esses valores se aproximam dos resultados obtidos por Marchetto et al. (2003), com uso de fonte de esgoto sintético e glicose como fontes de carbono.

Almeida et al. (1995) obtiveram resultados semelhantes com velocidade de desnitrificação via nitrito menor que a via nitrato. Os autores relataram que isso ocorreu por que as células não estavam especificamente adaptadas ao nitrito. $\mathrm{O}$ mesmo provavelmente ocorreu no experimento (Figura 5.15), considerando-se que na condição operacional de $125 \mathrm{mg} \mathrm{N} / \mathrm{L}$ houve predominância de nitrato com desnitrificação a partir dessa via.

Do mesmo modo, a eficiência de remoção de nitrogênio (Tabela 5.6) confirma essa adaptação. Embora a relação $\mathrm{C} / \mathrm{N}$ tenha sido a mesma para os reatores R1 e R2, ocorreu maior eficiência de remoção no reator contendo inicialmente apenas nitrato (R1). 
Tabela 5.6 - Concentrações de nitrito e nitrato e eficiência de remoção nos reatores R1 e R2.

\begin{tabular}{|c|c|c|c|c|c|}
\hline \multirow[b]{2}{*}{ Reator } & \multicolumn{2}{|l|}{ Entrada } & \multicolumn{2}{|c|}{ Saída } & \multirow{2}{*}{$\begin{array}{l}\text { Eficiência de } \\
\text { remoção }(\%)\end{array}$} \\
\hline & $\begin{array}{l}\text { Nitrito } \\
(\mathrm{mg} / \mathrm{L})\end{array}$ & $\begin{array}{l}\text { Nitrato } \\
(\mathrm{mg} / \mathrm{L})\end{array}$ & $\begin{array}{l}\text { Nitrito } \\
\text { (mg/L) }\end{array}$ & $\begin{array}{l}\text { Nitrato } \\
(\mathrm{mg} / \mathrm{L})\end{array}$ & \\
\hline $\mathrm{R} 1$ & ND & 10 & ND & 0,28 & 93 \\
\hline $\mathrm{R} 2$ & 10 & ND & 1,33 & ND & 78 \\
\hline
\end{tabular}

\section{2 - Concentração de $\mathrm{N}$-amoniacal afluente de $250 \mathrm{mg} \mathrm{N} / \mathrm{L}$}

A condição operacional de N-amoniacal de $250 \mathrm{mg} \mathrm{N} / \mathrm{L}$ efetuada em concentração de $\mathrm{OD}$ de $2 \mathrm{mg} \mathrm{O}_{2} / \mathrm{L}$ resultou, predominantemente, em nitrito como produto da nitrificação.

\subsection{1 - Remoção de nitrogênio e efeito da aeração intermitente}

\subsubsection{1 - Análise geral - monitoramento}

A remoção de nitrogênio, considerando as três formas de nitrogênio: Namoniacal afluente e efluente, nitrato e nitrito efluente, foi acima de $80 \% \mathrm{em}$ concentração de $\mathrm{OD}$ de $2 \mathrm{mg} \mathrm{O}_{2} / \mathrm{L}$, como pode ser observado na Figura 5.16.

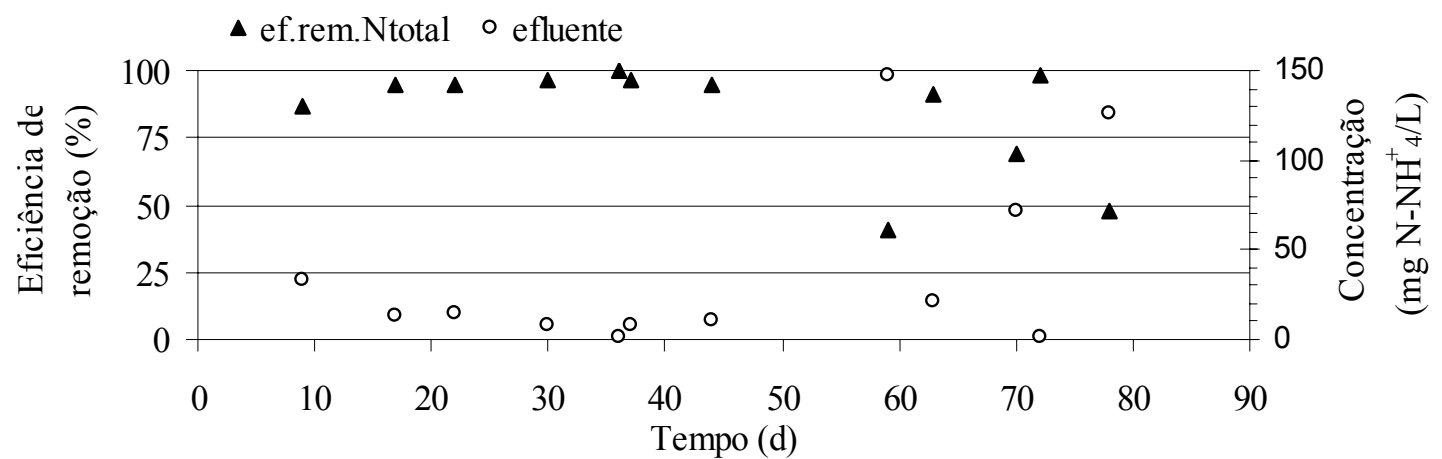

Figura 5.16 - Eficiência de remoção de nitrogênio e variação das concentrações de N-amoniacal efluente durante a condição operacional de $250 \mathrm{mg} \mathrm{N} / \mathrm{L}$.

A concentração inicial de SSV no reator no início da operação com concentração de $250 \mathrm{mg} \mathrm{N} / \mathrm{L}$, foi 6,61 g/L com IVL de $93 \mathrm{~mL} / \mathrm{g}$ (que indicou uma sedimentabilidade boa do lodo). A relação média de SSV/SST foi de 0,91 , maior que a relação de 0,8 
encontrada em sistema de lodos ativados convencional (PAMBRUM et al., 2004) indicou que houve uma quantidade de substâncias minerais em menor proporção que a usual.

Com relação à fonte de carbono escolhida, o amido foi quase todo consumido durante o processo de nitrificação/ desnitrificação, considerando-se que a eficiência de remoção média de DQO foi de $95 \%$.

A análise microbiológica do lodo nessa condição operacional de $\mathrm{N}$-amoniacal pode ser observada pelas imagens da Figura 5.17. Foram observadas bactérias com inclusões de polifosfato e filamentosas. As bactérias acumuladoras de fósforo também podem desnitrificar (CALLADO e FORESTI, 2001; AHN et al., 2002).
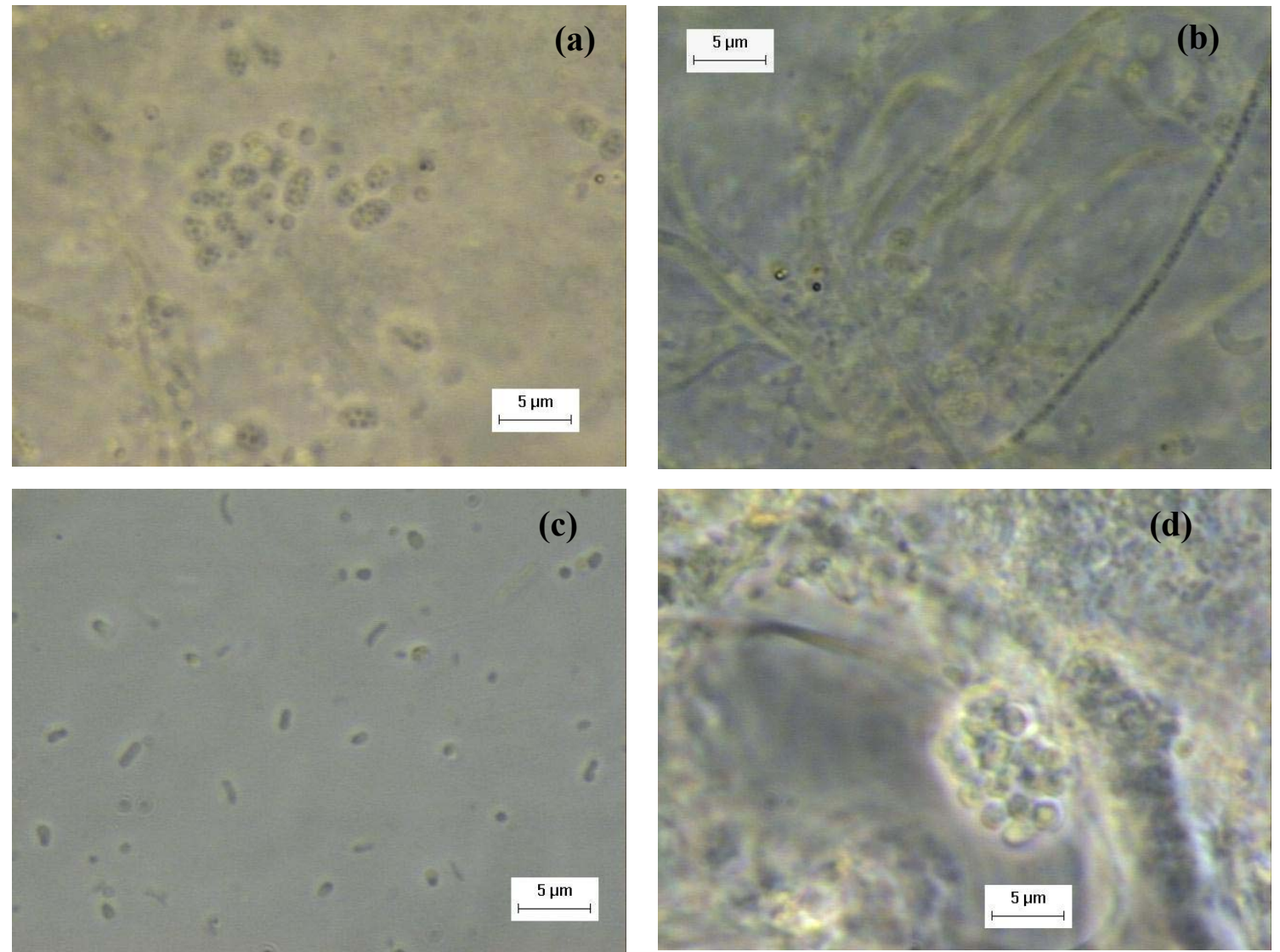

Figura 5.17 - Microfotografias microscopia ótica ao final da condição operacional de $250 \mathrm{mg}$

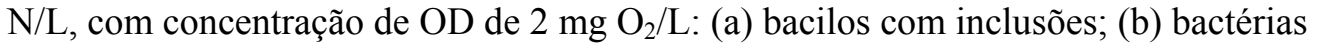
filamentosas; (c) bacilos diversos; (d) arranjo de cocos

\subsubsection{2 - Análise pontual - análise da batelada de $24 \mathrm{~h}$}

O produto final da nitrificação foi predominantemente nitrito, que foi subseqüentemente desnitrificado em cada período anóxico, como pode ser observado 
nas Figuras 5.18a e 5.18b.

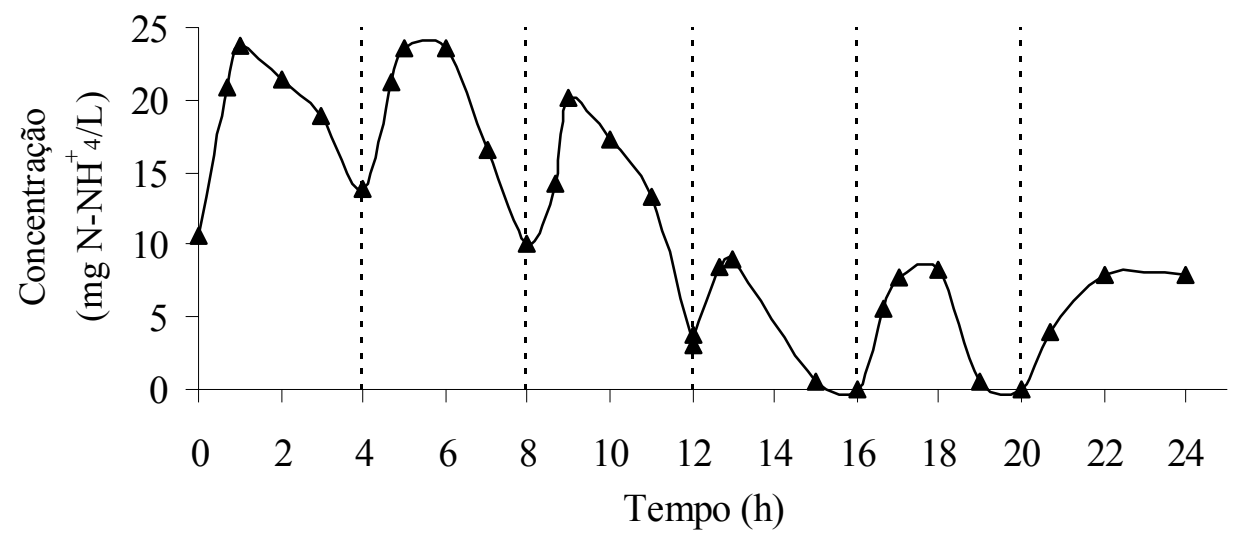

(a)
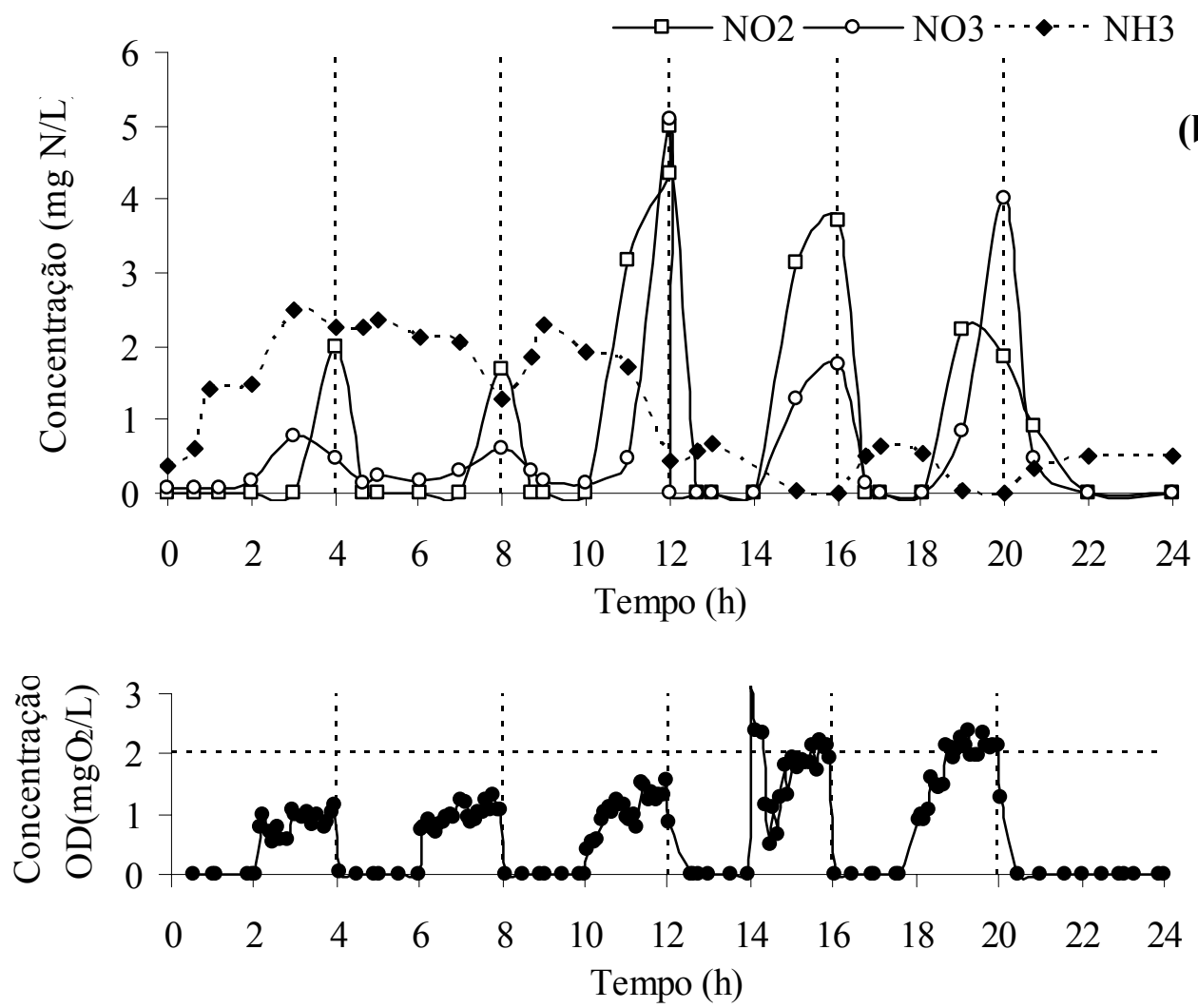

(c)

Figura 5.18 - Variação temporal dos parâmetros durante a condição operacional de $250 \mathrm{mg} \mathrm{N} / \mathrm{L}$, aos 30 dias de experimento: (a) N-amoniacal); (b) nitrato $\left(\mathrm{mg} \mathrm{N}^{-N^{-}}{ }_{2}^{-} / \mathrm{L}\right)$, nitrito $\left(\mathrm{mg} \mathrm{N}^{-\mathrm{NO}_{3}^{-}} / \mathrm{L}\right)$ e amônia livre (mg N-NH$/ \mathrm{L}$ ); (c) oxigênio dissolvido.

Nesse caso, o controle da concentração de oxigênio dissolvido no reator não ocorreu como planejado (Figura 5.18c), com obtenção de concentração de OD média de $1 \mathrm{mg} \mathrm{O} / \mathrm{L}$ nos dois primeiros ciclos aeróbios, acompanhado da produção e consumo de

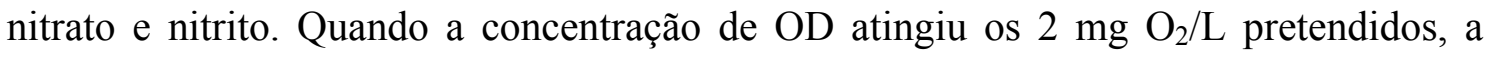
produção de nitrato e nitrito acompanhou a mesma tendência, além da diminuição da concentração de amônia livre. Os mesmos resultados se repetiram na variação temporal 
realizada aos 43 dias de experimento (Figura 5.19c).

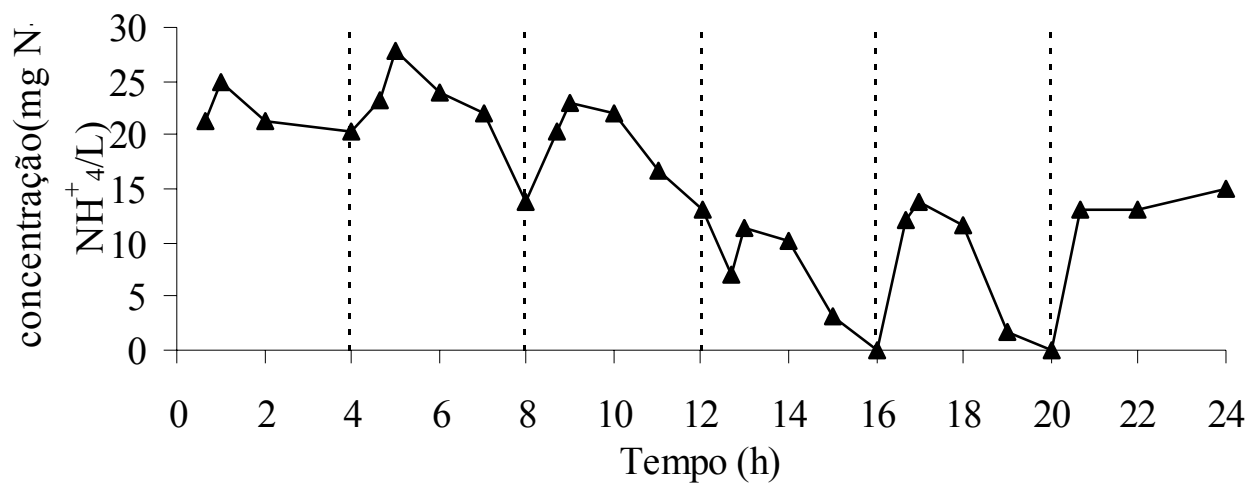

(a)

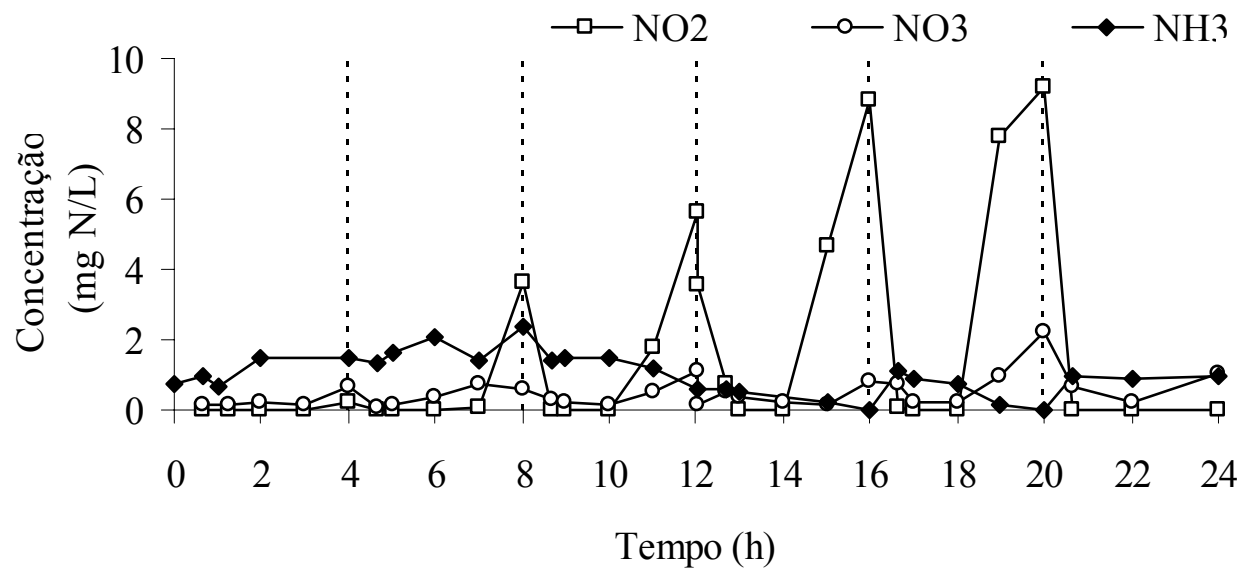

(b)

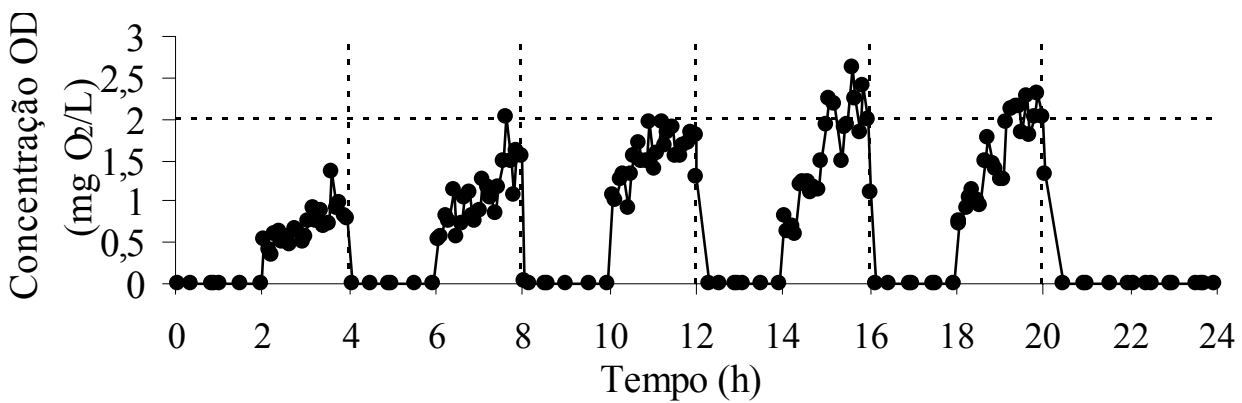

(c)

Figura 5.19 - Variação temporal dos parâmetros durante a condição operacional de $250 \mathrm{mg}$ N/L aos 43 dias de experimento: (a) $\mathrm{N}$-amoniacal; (b) nitrato $\left(\mathrm{mg} \mathrm{N}^{-N^{-}}{ }_{2} / \mathrm{L}\right)$, nitrito $\left(\mathrm{mg} \mathrm{N}^{-N^{-}}{ }_{3} / \mathrm{L}\right)$

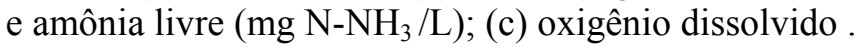

Pode-se observar que o consumo de N-amoniacal e a produção de nitrito e nitrato foram, aparentemente, retardados pelo longo período anóxico e pela concentração inicial de amônia livre e de OD no reator.

Apesar disso, quando o reator foi submetido a aeração no $3^{\circ}$ ciclo aeróbio $(\mathrm{t}=10 \mathrm{~h})$, nitrito e nitrato ocorreram em concentrações maiores $(5 \mathrm{mg} \mathrm{N} / \mathrm{L})$ e quase todo $\mathrm{N}$-amoniacal foi consumido (Figuras 5.18a e 5.19a).

Segundo Zeng et al., (2003), a eficiência de remoção de nitrogênio por NDS 
(nitrificação e desnitrificação simultâneas) é calculada pela seguinte Equação no final do período aeróbio:

$$
\text { Eficiência de NDS }=\frac{\mathrm{NH}^{+}}{{ }_{4}} \underline{\text { nitrificado }-\mathrm{NO}} \underline{\mathrm{NH}^{+}}
$$
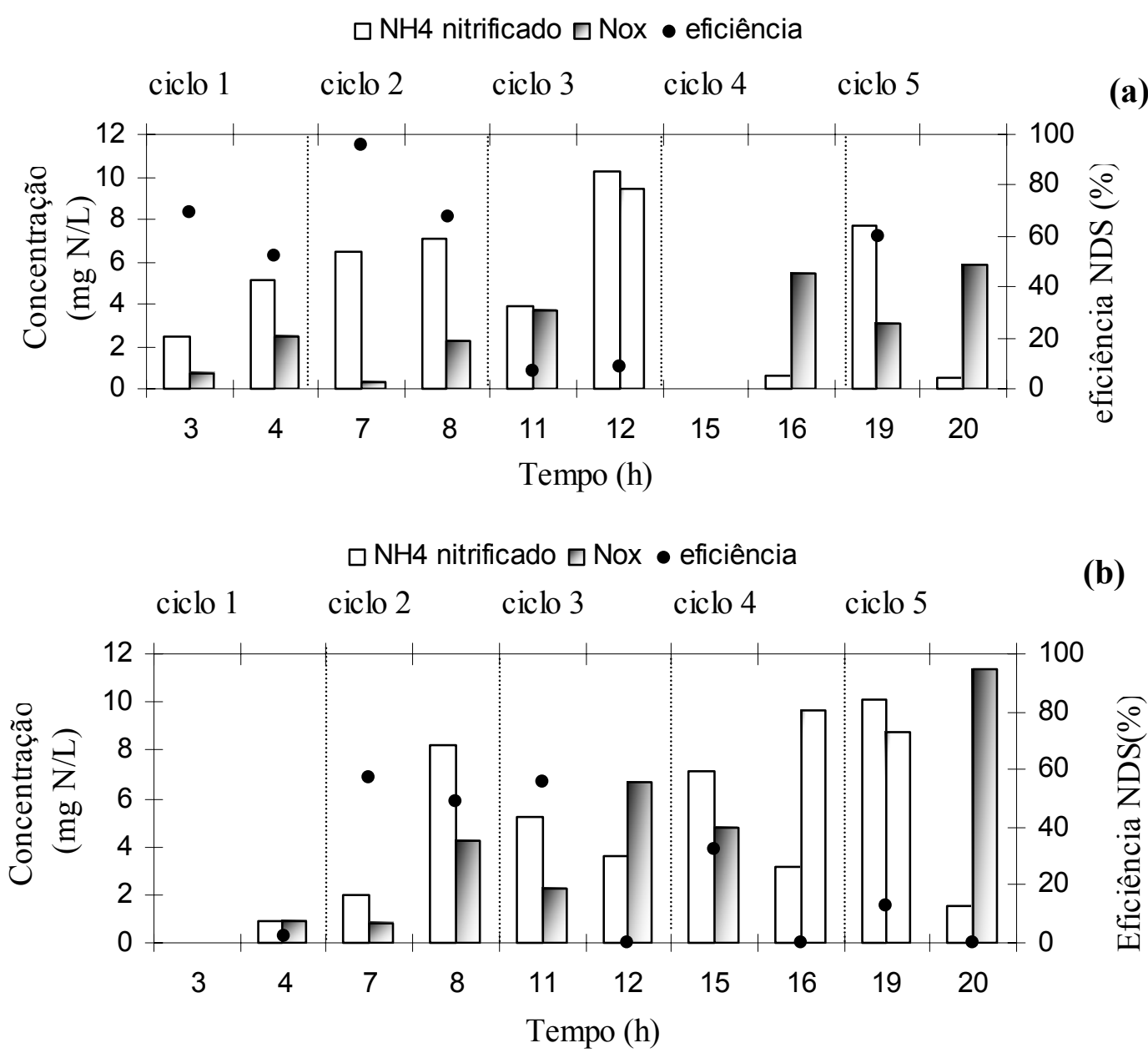

Figura 5.20 - Verificação da NDS durante a condição operacional de $250 \mathrm{mg} \mathrm{N} / \mathrm{L}$ : (a) aos 30 dias e (b) aos 43 dias de experimento.

Considerando-se a Figura 5.20a ocorreu NDS significativa nos dois primeiros ciclos aos 30 dias de experimento, enquanto aos 43 dias (Figura 5.20b) foi nos ciclos 2, 3 e 4. Comparando as Figuras 5.18b e 5.20a. (aos 30 dias), a concentração de amônia livre é mais alta nos dois primeiros ciclos que nos outros ciclos, juntamente com a concentração baixa de OD.

Aos 43 dias, observando-se a Figura 5.19 e 5.20b, quase não houve oxidação de Namoniacal no primeiro ciclo com NDS significativa no segundo e terceiro ciclos, com uma queda no quarto e quinto ciclos, coincidindo com a queda da concentração de 
amônia livre e aumento da concentração de OD.

\subsubsection{Efeito da aeração intermitente}

A operação sob aeração intermitente tem um papel importante, pois permite o controle da inibição por substrato (amônia livre e ácido nitroso livre) com estabilidade do $\mathrm{pH}$ e remoção eficiente de nitrogênio.

Os valores obtidos de amônia livre nos três primeiros ciclos, no início dos períodos aeróbios, como podem ser observados nas Figuras 5.21a e 5.21b, estão dentro da faixa inibitória da nitratação, de acordo com Abeling e Seyfried (1992) e resultaram em NDS como pode ser visto nas Figuras 5.20a e 5.20b.

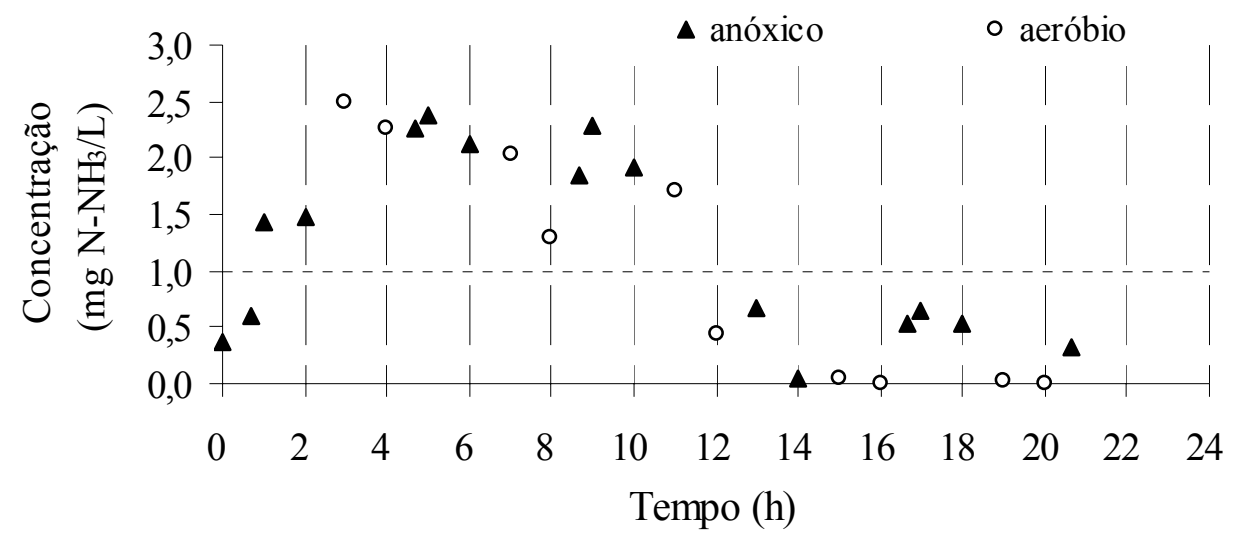

(a)

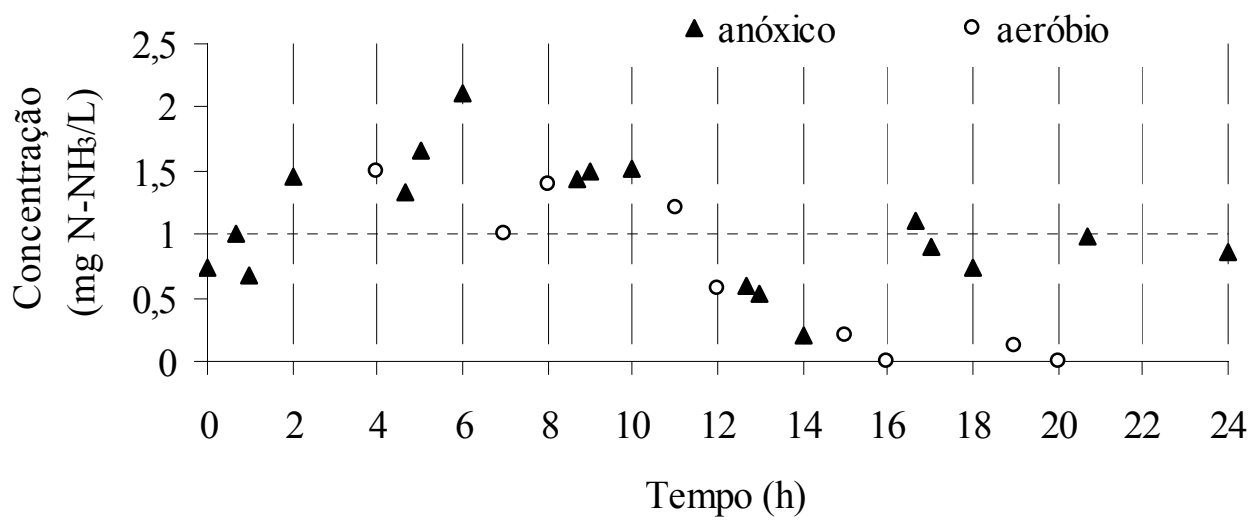

(b)

Figura 5.21 - Variação temporal das concentrações de amônia livre (mg N-NH$/ \mathrm{L})$, durante a condição operacional de $250 \mathrm{mg} \mathrm{N} / \mathrm{L}$ : (a) aos 30 dias; (b) aos 43 dias de experimento.

Os resultados de amônia livre também podem ser comparados aos resultados de Çeçen (1996) de OD/ $\mathrm{NH}_{3}<10$ e $\mathrm{OD} / \mathrm{NH}^{+}{ }_{4}<1$, considerados indicativos de acúmulo de 
nitrito no reator.

Nesse experimento, considerando-se concentração média de $25 \mathrm{mg} \mathrm{N}-\mathrm{NH}^{+}{ }_{4} / \mathrm{L}$ e concentração média de $\mathrm{OD}$ de $2 \mathrm{mg} \mathrm{O}_{2} / \mathrm{L}$, as relações de $\mathrm{OD} / \mathrm{NH}_{3}=1,2$ e de $\mathrm{OD} / \mathrm{NH}_{4}^{+}=0,08$, provavelmente não foram às condições que favoreceram o acúmulo de nitrito, entretanto podem ter contribuído para a ocorrência de NDS.

$\mathrm{O} \mathrm{pH}$ foi favorecido pela aeração intermitente, pois o $\mathrm{pH}$ efluente (Figura 5.22) manteve-se predominantemente na faixa recomendada por Metcalf e Eddy (1991). O reator operou com $\mathrm{pH}$ médio afluente de $8,1 \pm 1(7,9-8,2)$ e com valor de $\mathrm{pH}$ médio efluente de $8,2 \pm 1(7,7-9)$.

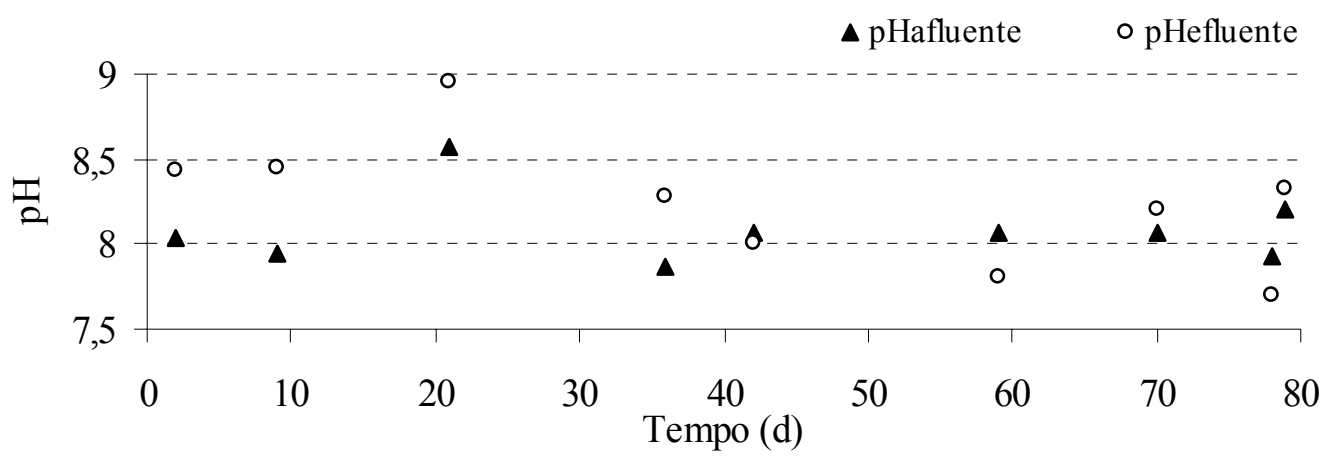

Figura 5.22 - Variação dos valores de pH afluente e efluente durante a condição operacional de $250 \mathrm{mg} \mathrm{N} / \mathrm{L}$.

Os valores mostrados na Figura 5.22 obtidos ao longo do experimento indicaram que houve ganho de alcalinidade, demonstrado pelo valor de $\mathrm{pH}$ efluente acima do $\mathrm{pH}$ do afluente.

Os valores de $\mathrm{pH}$ durante um ciclo de $24 \mathrm{~h}$ (Figura 5.23) também permaneceram dentro da faixa de $\mathrm{pH}$ recomendada por Metcalf e Eddy (1991). O comportamento esperado do perfil de $24 \mathrm{~h}$ seria o de aumento no período anóxico e decréscimo no decorrer do período aeróbio, em decorrência da produção e consumo de alcalinidade. Esse padrão não ocorreu como ser observado nas Figuras 5.23a e 5.23b. 


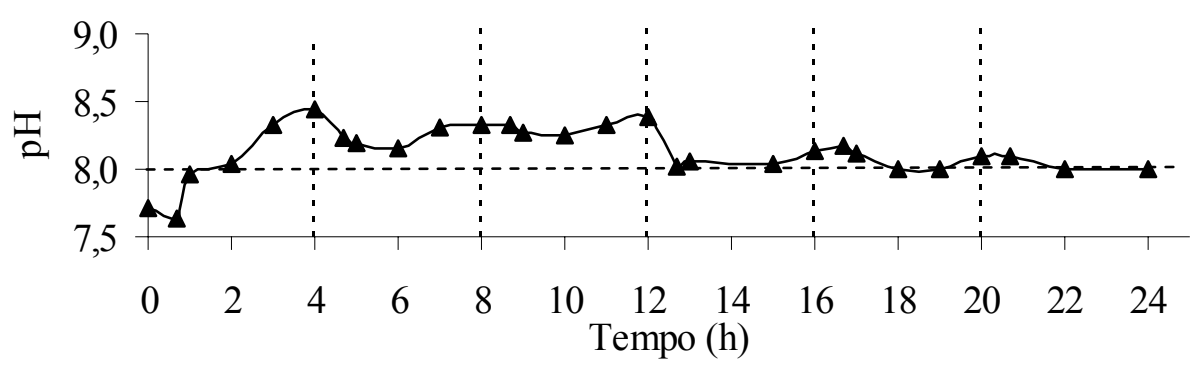

(a)

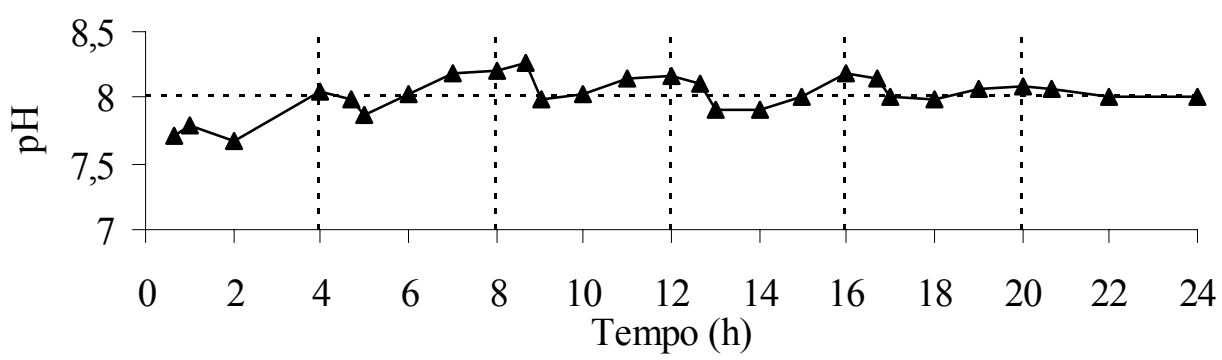

(b)

Figura 5.23 - Variação temporal dos valores de pH durante a condição operacional de $250 \mathrm{mg}$ N/L: (a) aos 30 dias e (b) aos 43 dias de experimento.

A concentração média de $\mathrm{AB}$ no efluente de $1300 \mathrm{mg} \mathrm{CaCO}^{-} / \mathrm{L}$ foi $69 \%$ da $\mathrm{AB}$ no afluente, indicando que o processo de desnitrificação procedeu de maneira a balancear a alcalinidade gasta em cada período aerado (Figura 5.24).

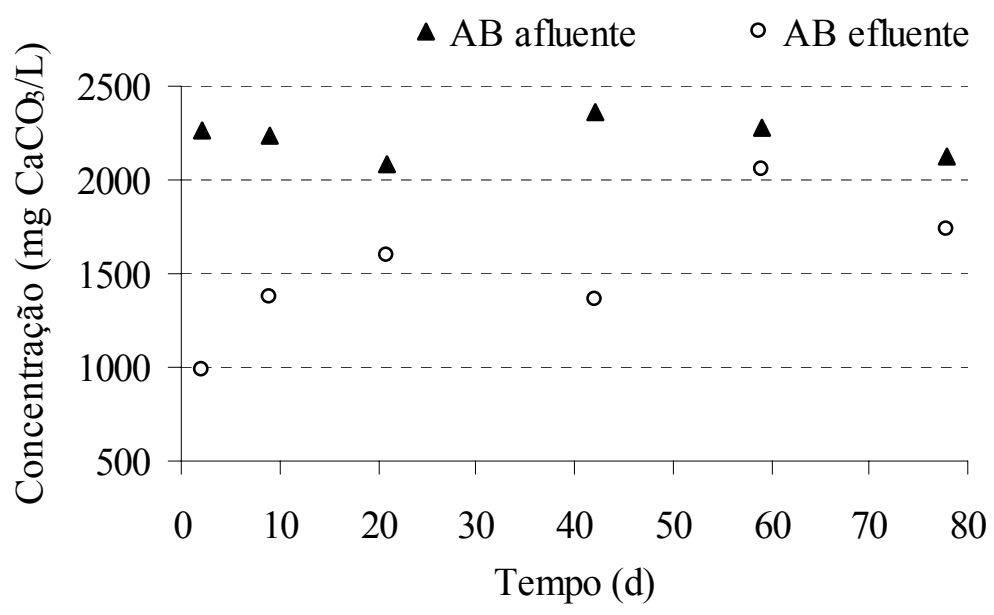

Figura 5.24 - Variação das concentrações de alcalinidade a bicarbonato (AB) afluente e efluente durante a condição operacional de $250 \mathrm{mg} \mathrm{N} / \mathrm{L}$.

\subsection{3 - Potencial redox e OD}

Os valores de potencial redox (Figura 5.25) foram baixos inicialmente (ao redor de $-150 \mathrm{RmV}$ ) e acompanharam os valores de concentração de OD. Durante os dois primeiros períodos anóxicos, os valores de potencial redox tiveram comportamento 
semelhante, com valores próximos, enquanto que nos outros três períodos anóxicos (com concentrações iniciais maiores de nitrito no reator), os valores de potencial redox foram mais negativos. Esse padrão se repetiu, conforme mostrado na Figura 5.26.

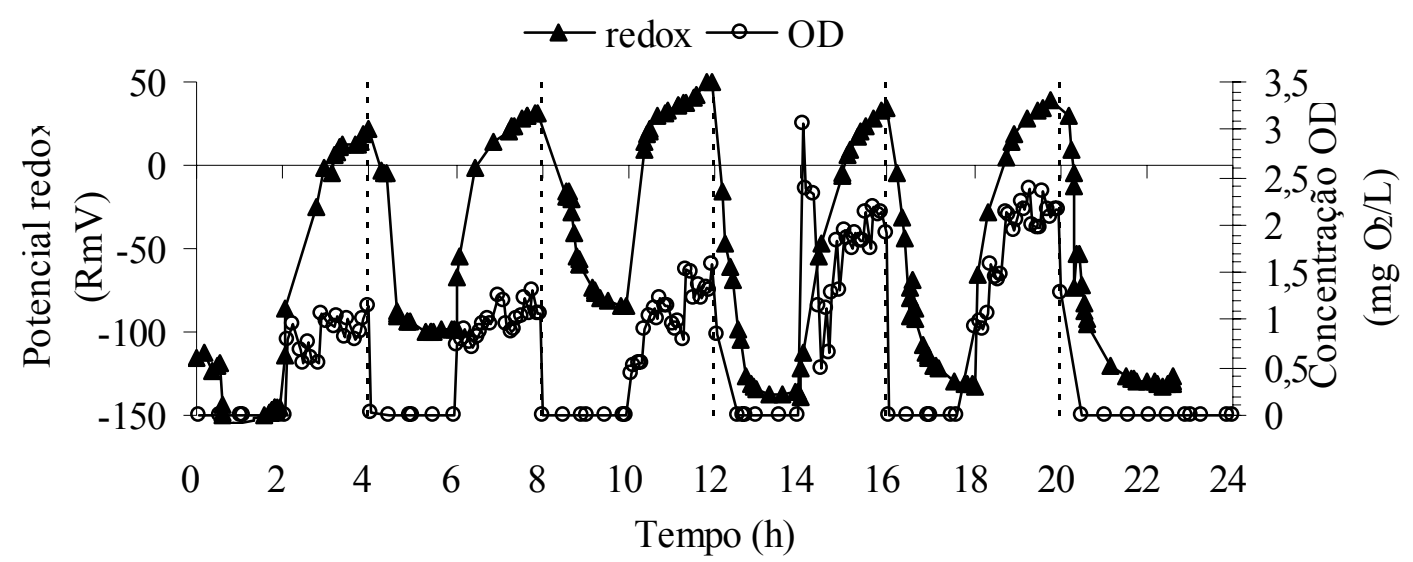

Figura 5.25 - Variação temporal dos valores de potencial redox e das concentrações de OD durante a condição operacional de $250 \mathrm{mg} \mathrm{N} / \mathrm{L}$ aos 30 dias.

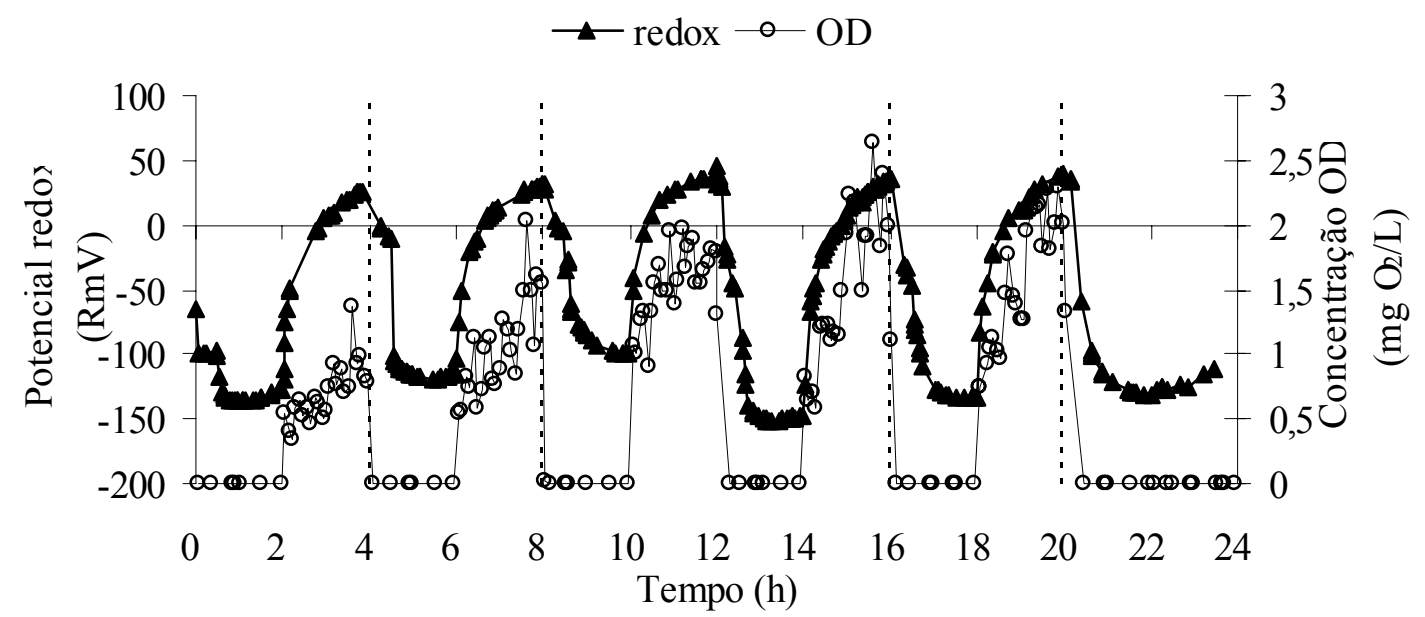

Figura 5.26 - Variação temporal dos valores de potencial redox e das concentrações de OD durante a condição operacional de $250 \mathrm{mg} \mathrm{N} / \mathrm{L}$ aos 43 dias.

\subsection{4 - Perfil temporal de um ciclo anóxico/ aeróbio de 4 h}

Realizou-se ensaio de $4 \mathrm{~h}$, com amostras retiradas a cada 15 minutos com a finalidade de se estabelecer relações entre as variáveis envolvidas: potencial redox, oxigênio dissolvido e concentração de nitrato.

Com relação à variação temporal dos valores potencial redox comparado à variação temporal das concentrações de OD, que pode ser observado na Figura $5.27 \mathrm{~d}$, a 
mudança da fase anóxica para aeróbia é acompanhada pelas duas variáveis. A mudança da concentração de OD concorda com a mudança da curva do potencial redox.

Na Figura 5.27b, os valores de potencial redox são comparados às concentrações de nitrito durante o $3^{\circ}$ ciclo anóxico/aeróbio. A concentração de nitrito se ajustou às mudanças de potencial redox com o tempo. Após a mudança de inclinação $(t=12,5 h)$, quando o potencial redox atingiu o valor de $-117 \mathrm{RmV}$ em $\mathrm{t}=12,85 \mathrm{~h}$ e a variação de seus valores foi muito pequena $(\Delta= \pm 3 \mathrm{RmV})$, todo o nitrito e nitrato foram desnitrificados em menos de uma hora.

No período aeróbio observado na Figura 5.27, no $\mathrm{t}=15,7 \mathrm{~h}$, as concentrações de nitrito e nitrato foram máximas, enquanto que no $\mathrm{t}=14,9 \mathrm{~h}$, houve o consumo total de $\mathrm{N}$ amoniacal e, coincidentemente, foi o ponto onde começa o controle de OD. Portanto, em períodos anóxicos e aeróbios com duração de 1 hora, é possível nitrificar e desnitrificar em concentração amoniacal afluente de $250 \mathrm{mg} \mathrm{N} / \mathrm{L}$.
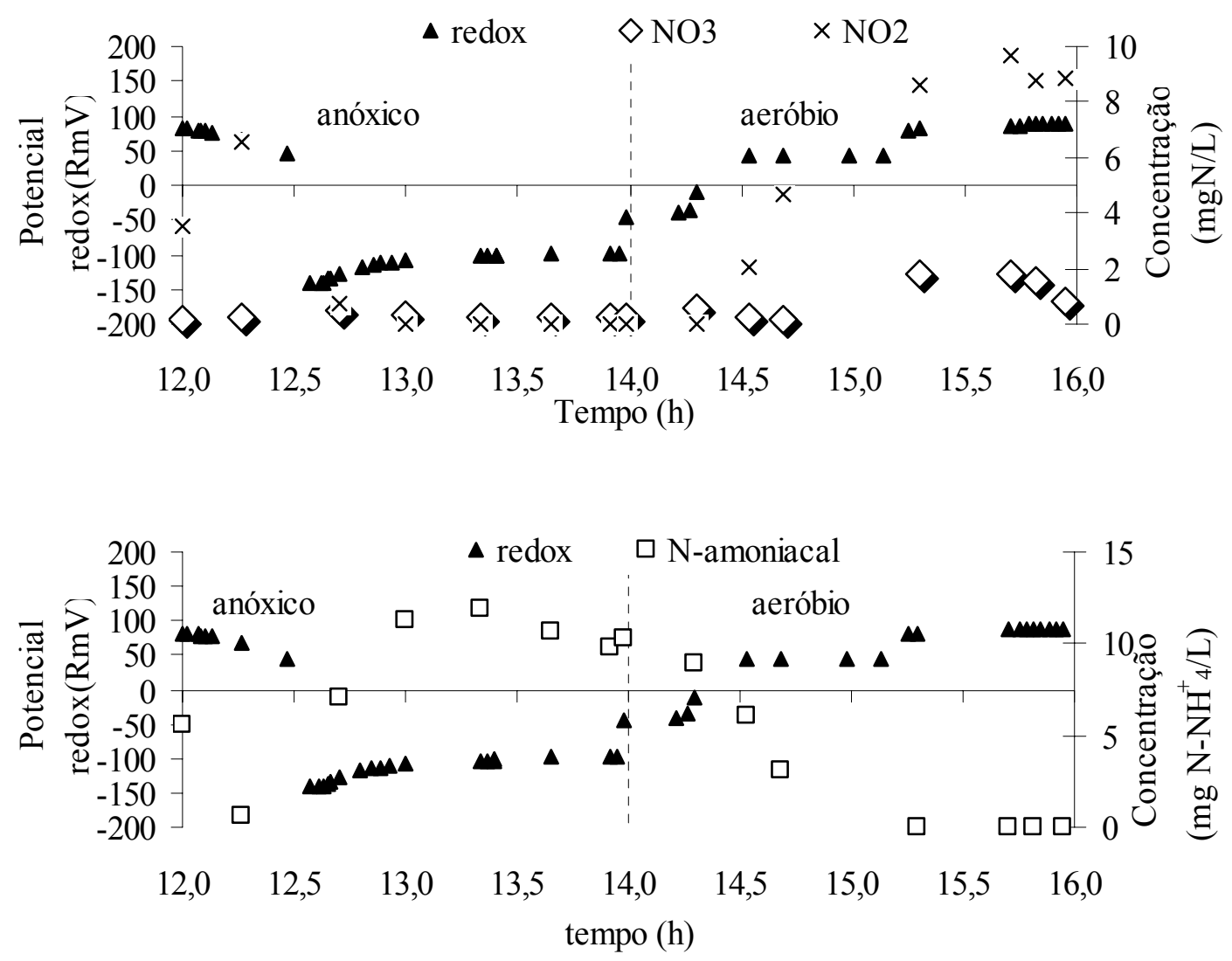

Figura 5.27 - Variação temporal dos parâmetros durante um ciclo anóxico/ aeróbio de $4 \mathrm{~h}$ durante a condição operacional de $250 \mathrm{mg} \mathrm{N} / \mathrm{L}$ em concentração média de OD de $2 \mathrm{mg} \mathrm{O} \mathrm{O}_{2} / \mathrm{L}$ :

(a) potencial redox com concentrações de nitrato e nitrito; (b) potencial redox com concentrações de $\mathrm{N}$-amoniacal. 


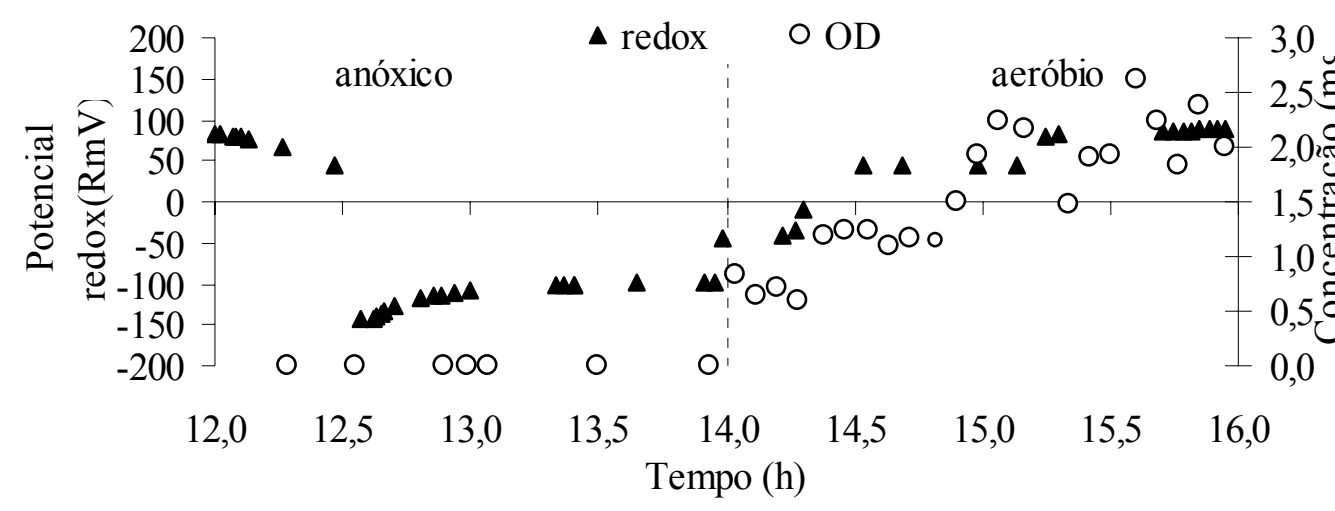

(c)

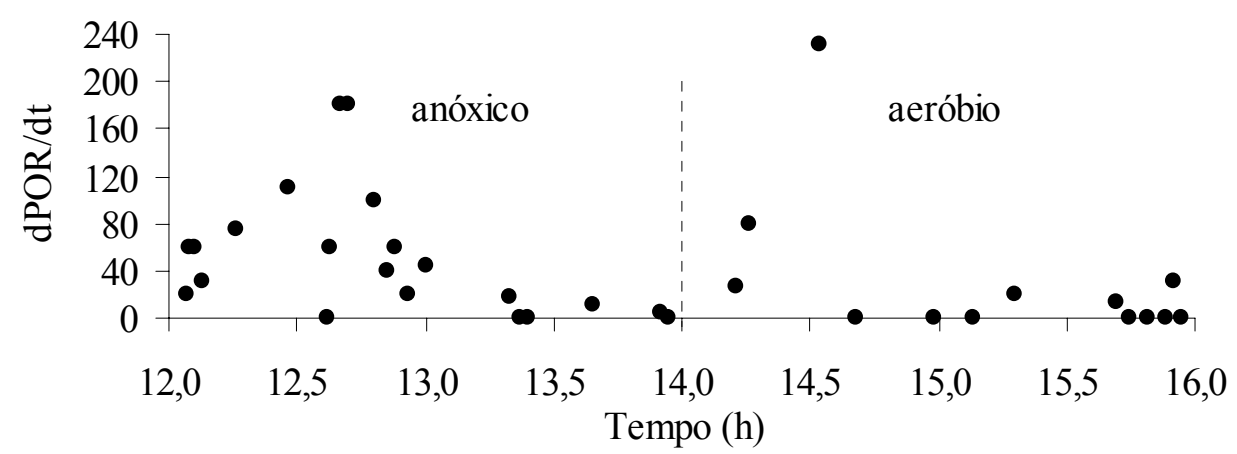

Figura 5.27 - Variação temporal dos parâmetros durante um ciclo anóxico/ aeróbio de $4 \mathrm{~h}$ durante a condição operacional de $250 \mathrm{mg} \mathrm{N} / \mathrm{L}$ em concentração média de OD de $2 \mathrm{mg} \mathrm{O} / \mathrm{L}$ : (c) potencial redox com concentrações de $\mathrm{OD}$; (d) variação do potencial redox com o tempo $(\mathrm{dPOR} / \mathrm{dt})$.

\section{3 - Comparação entre condições operacionais de $\mathrm{N}$-amoniacal afluente - 125 e} $250 \mathrm{mg} \mathrm{N} / \mathrm{L}$

Optou-se por essa abordagem, porque, aparentemente, o reator obteve eficiências de remoção de $\mathrm{N}$-amoniacal semelhantes (Tabela 5.7, com a diferença no produto final no período de aeração) nessas duas condições.

Na condição operacional de N-amoniacal de $125 \mathrm{mg} \mathrm{N} / \mathrm{L}$, as concentrações de amônia livre sempre estiveram abaixo de $0,7 \mathrm{mg} \mathrm{N}-\mathrm{NH}_{3} / \mathrm{L}$ nos períodos aeróbios. Estes valores estão abaixo dos valores relatados em literatura para inibição da nitratação (ABELING e SEYFRIED, 1992).

Este pode ser um dos motivos que diferenciou a operação em concentração de $\mathrm{N}$-amoniacal de $125 \mathrm{mg} \mathrm{N} / \mathrm{L}$ (nitrato como produto principal da nitrificação) e $250 \mathrm{mg}$ N/L (nitrificação e desnitrificação simultâneas nos dois primeiros ciclos, com predominância de nitrito). 
Tabela 5.7 - Resultados de monitoramento nas condições operacionais de $\mathrm{N}$-amoniacal de 125 e $250 \mathrm{mg} \mathrm{N} / \mathrm{L}$.

\begin{tabular}{|c|c|c|}
\hline Parâmetro & $\begin{array}{l}125 \mathrm{mg} \mathrm{N} / \mathrm{L} \text { como N- } \\
\text { amoniacal }\end{array}$ & $\begin{array}{c}250 \mathrm{mg} \mathrm{N} / \mathrm{L} \text { como N- } \\
\text { amoniacal }\end{array}$ \\
\hline \multicolumn{3}{|l|}{ Afluente } \\
\hline $\mathrm{DQO}_{\mathrm{T}}(\mathrm{mg} / \mathrm{L})$ & $1032 \pm 194$ & $1871 \pm 193$ \\
\hline $\mathrm{DQO}_{\mathrm{f}}(\mathrm{mg} / \mathrm{l})$ & $895 \pm 43$ & $1513 \pm 242$ \\
\hline $\mathrm{pH}$ & $8,1 \pm 1$ & $8,1 \pm 1$ \\
\hline $\mathrm{AB}\left(\mathrm{mg} / \mathrm{L} \mathrm{CaCO}_{3}^{-}\right)$ & $1029 \pm 15$ & $2556 \pm 889$ \\
\hline \multicolumn{3}{|l|}{ Efluente } \\
\hline $\mathrm{DQO}_{\mathrm{T}}(\mathrm{mg} / \mathrm{L})$ & $58 \pm 85$ & $101 \pm 83$ \\
\hline $\mathrm{DQO}_{\mathrm{f}}(\mathrm{mg} / \mathrm{L})$ & $17 \pm 6$ & $45 \pm 48$ \\
\hline $\mathrm{pH}$ & $8,4 \pm 1$ & $8,2 \pm 1$ \\
\hline N-amoniacal & $9 \pm 4$ & $38 \pm 50$ \\
\hline$\varepsilon \mathrm{DQO}_{\mathrm{T}}(\%)$ & $94 \pm 9$ & $95 \pm 5$ \\
\hline$\varepsilon \mathrm{DQO}_{\mathrm{f}}(\%)$ & $98 \pm 3$ & $97 \pm 4$ \\
\hline$\varepsilon \mathrm{N}$-amoniacal & $87 \pm 2$ & $84 \pm 21$ \\
\hline $\mathrm{AB}\left(\mathrm{mg} / \mathrm{L} \mathrm{CaCO}_{3}^{-}\right)$ & $640 \pm 31$ & $1300 \pm 664$ \\
\hline
\end{tabular}

$\mathrm{AB}=$ alcalinidade a bicarbonato

Observando-se as Figuras 5.18a e 5.18b (durante a condição operacional de Namoniacal de $250 \mathrm{mg} \mathrm{N} / \mathrm{L}$ ), as concentrações de amônia livre nos três primeiros ciclos estão ao redor de $2 \mathrm{mg} \mathrm{N}-\mathrm{NH}_{3} / \mathrm{L}$ nos períodos aeróbios. A condição de nitrificação e desnitrificação simultâneas, no período aeróbio, é indicada pelo fato da produção de Nox $\left(\mathrm{NO}_{2}^{-}+\mathrm{NO}_{3}^{-}\right)$ter sido menor que o consumo de $\mathrm{N}$-amoniacal durante o período aeróbio (Figura 5.20).

Os processos de nitrificação e desnitrificação simultâneas são, provavelmente, causadas por uma limitação de transferência de massa nos flocos (MUNCH et al., 1996; POCHANA e KELLER, 1999; CHEN et al., 2000 e KIM et al., (2003)). Como a difusão limitaria a penetração de oxigênio, haveria uma zona aeróbia na parte externa do floco, onde a nitrificação ocorre, além de uma zona anóxica no centro do floco, onde as bactérias heterotróficas poderiam promover a desnitrificação.

Munch et al. (1996) e Zhao et al. (1999) consideraram a existência de microrganismos desnitrificantes aeróbios e nitrificantes heterotróficas como sendo uma das causas para a ocorrência de nitrificação e desnitrificação simultâneas. As bactérias nitrificantes heterotróficas têm crescimento e rendimento maior que as nitrificantes autotróficas, além de requererem menor concentração de OD, tolerando um ambiente mais ácido. Similarmente, comparadas com as desnitrificantes anóxicas, as bactérias desnitrificantes aeróbias teriam menores velocidades de desnitrificação e maior vantagem ecológica em nichos aeróbios/anóxicos, como ocorreu nesse experimento. 
A aeração intermitente prolonga fase lag de crescimento das bactérias oxidantes de nitrito, causando acúmulo de nitrito. Desse modo, o período de aeração deve ser curto o suficiente para evitar a adaptação das bactérias oxidantes de nitrito ao ambiente aeróbio (YOO et al., 1999).

A presença de amônia livre e seu efeito inibitório não podem ser tomados como principais fatores que afetaram a remoção diferenciada em cada concentração de Namoniacal aplicada. Deve-se considerar que as concentrações inibitórias podem ser diferentes quando há lodos adaptados. Turk e Mavinic (1989) obtiveram acúmulo de nitrito em concentrações de até $40 \mathrm{mg} \mathrm{N}-\mathrm{NH}_{3} / \mathrm{L}$, sem ocorrência de inibição. Outro produto intermediário, a hidroxilamina $\left(\mathrm{NH}_{2} \mathrm{OH} / \mathrm{NH}_{3} \mathrm{OH}^{+}\right)$, foi considerado por Yang e Alleman (1992) como a causa para a inibição da nitratação por Nitrobacter sp. A hidroxilamina acumulou-se em sistema nitrificante com alta concentração $\mathrm{NH}_{3} / \mathrm{NH}_{4}^{+}$, em meio contendo baixa concentração de oxigênio e pH elevado.

Além da presença de amônia livre em condições inibitórias, a concentração de OD no experimento não atingiu plenamente a concentração pretendida de $2 \mathrm{mg} \mathrm{O}_{2} / \mathrm{L}$ durante os 2 primeiros ciclos aeróbios (Figura 5.18c e 5.19c), talvez devido ao longo período anóxico anterior. Esse intervalo de tempo compreendeu $2 \mathrm{~h}$ (período anterior de sedimentação) somado ao o primeiro período anóxico.

De acordo com Yoo et al. (1999), o controle da concentração de OD foi essencial para efetivamente suprimir a nitratação e atingir a NDS. Esse controle pode ser feito de dois modos: (1) controle da máxima concentração de OD no final do período aeróbio e (2) controle da velocidade de aumento da vazão de ar.

Para a condição operacional de N-amoniacal de $125 \mathrm{mg} \mathrm{N} / \mathrm{L}$, obteve-se controle da concentração de OD conforme planejado (Figuras 5.11 e 5.12). Contudo, para concentração de $\mathrm{N}$-amoniacal de $250 \mathrm{mg} \mathrm{N} / \mathrm{L}$, o controle não ocorreu como planejado (Figura 5.18c e 5.19c), com concentração de OD média de $1 \mathrm{mg} \mathrm{O}_{2} / \mathrm{L}$ nos dois primeiros ciclos aeróbios, acompanhado das mudanças de produção de nitrato e nitrito. Quando a concentração de OD atingiu os $2 \mathrm{mg} \mathrm{O}_{2} / \mathrm{L}$ pretendidos, a produção de nitrato e nitrito acompanhou a mesma tendência, além de ter ocorrido a diminuição da concentração de amônia livre. 


\section{4 - Concentração de N-amoniacal de $500 \mathrm{mg} \mathrm{N} / \mathrm{L}$}

O desempenho do reator na condição operacional de $\mathrm{N}$-amoniacal de $500 \mathrm{mg}$ N/L foi completamente distinto do observado para as concentrações menores anteriormente utilizadas. Quando o reator foi submetido às mesmas condições anteriores ( $\mathrm{pH}$ afluente de 7,9 , OD de 2 a $2,5 \mathrm{mg} \mathrm{O}_{2} / \mathrm{L}$ e aeração intermitente a cada $2 \mathrm{~h}$ ), a eficiência de remoção de nitrogênio diminuiu de 80\% (Tabela 5.1) para 55\% (como pode ser visto na Tabela 5.8 e Figura 5.28a). Houve predominância de nitrato como produto final da nitrificação e as eficiências de remoção de $\mathrm{N}$-amoniacal e $\mathrm{N}$ foram equivalentes.

Tabela 5.8 - Condições de operação e resultados de remoção de nitrogênio durante condição operacional de $500 \mathrm{mg} \mathrm{N} / \mathrm{L}$.

\begin{tabular}{cccccc}
\hline $\begin{array}{l}\text { Anóxico/ } \\
\text { aeróbio }\end{array}$ & $\begin{array}{l}\text { Concentração } \\
\text { de OD (mg afluente } \\
\left.\mathrm{O}_{2} / \mathrm{L}\right) \text { teórico }\end{array}$ & & $\begin{array}{l}\text { Eficiência de } \\
\text { remoção de } \\
\text { N-amoniacal } \\
(\%)\end{array}$ & $\begin{array}{l}\text { Concentração } \\
\text { média de OD } \\
\left(\mathrm{mg} \mathrm{O}_{2} / \mathrm{L}\right) \\
\text { medido }\end{array}$ & $\begin{array}{l}\mathrm{pH} \\
\text { efluente }\end{array}$ \\
\hline $2 \mathrm{~h} / 2 \mathrm{~h}$ & 2 a 2,5 & $7,86 \pm 1,1$ & $55 \pm 14$ & $2,9 \pm 0,5$ & $8,47 \pm 1,1$ \\
$2 \mathrm{~h} / 2 \mathrm{~h}$ & 2,5 a 3,0 & $7,67 \pm 1$ & $33 \pm 17$ & $2,7 \pm 0,3$ & $7,44 \pm 1,8$ \\
$2 \mathrm{~h} / 4 \mathrm{~h}$ & 3 a 4,5 & $7,58 \pm 1$ & $19 \pm 9$ & $3,2 \pm 0,3$ & $7,67 \pm 1$ \\
$2 \mathrm{~h} / 4 \mathrm{~h}$ & 3 a 5 & $7,69 \pm 1$ & $35 \pm 29$ & $4,3 \pm 0,3$ & $7,45 \pm 1,1$ \\
$2 \mathrm{~h} / 9 \mathrm{~h}$ & 2,5 a 3 & $8,11 \pm 1$ & $94 \pm 9$ & $2,8 \pm 0,3$ & $8,00 \pm 1$ \\
\hline
\end{tabular}

Obs.: O programa $2 \mathrm{~h} / 4 \mathrm{~h}$ era composto de 1 ciclo anóxico/aeróbio de $1 \mathrm{~h} / 3 \mathrm{~h}$ mais 3 ciclos de anóxico/aeróbio de $2 \mathrm{~h} / 4 \mathrm{~h}$ mais período de descarte/sedimentação de $2 \mathrm{~h}$; completando uma batelada de $24 \mathrm{~h}$.

Com a finalidade de se aumentar a eficiência de remoção de nitrogênio, aumentou-se a concentração de OD para 2,5 a $3 \mathrm{mg} \mathrm{O} / \mathrm{L}$, juntamente com a diminuição do $\mathrm{pH}$, com o objetivo de se evitar a possível inibição da amônia livre à atividade das bactérias oxidantes de amônia. Como não se obteve o resultado pretendido, pois a eficiência de remoção de nitrogênio continuava baixa, aumentou-se a duração do ciclo de aeração para 4h com aumento da concentração de OD para 3 a 4,5 mg O $\mathrm{O}_{2} / \mathrm{L}$. Com aumento maior na concentração de OD de 3 a $5 \mathrm{mg} \mathrm{O} / \mathrm{L}$, em alguns momentos houve

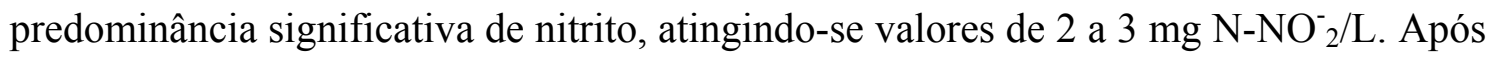
269 dias, a alternativa foi aumentar a duração do ciclo aeróbio para 9h. 


\subsection{1 - Remoção de nitrogênio}

\subsubsection{1- Análise geral - monitoramento}

A eficiência de remoção de nitrogênio em concentração de $\mathrm{N}$-amoniacal de 500 mg N/L manteve-se próxima a 50\%, como pode ser visto na Figura 5.28a e Tabela 5.8. $\mathrm{O}$ produto final da nitrificação para a concentração média de $\mathrm{OD}$ de $2,9 \mathrm{mg} \mathrm{O}_{2} / \mathrm{L}$ foi o nitrato, que foi obtido em concentrações de 0,1 a $1 \mathrm{mg} \mathrm{N}-\mathrm{NO}_{3}^{-} / \mathrm{L}$, enquanto nitrito ocorreu em concentrações insignificantes.
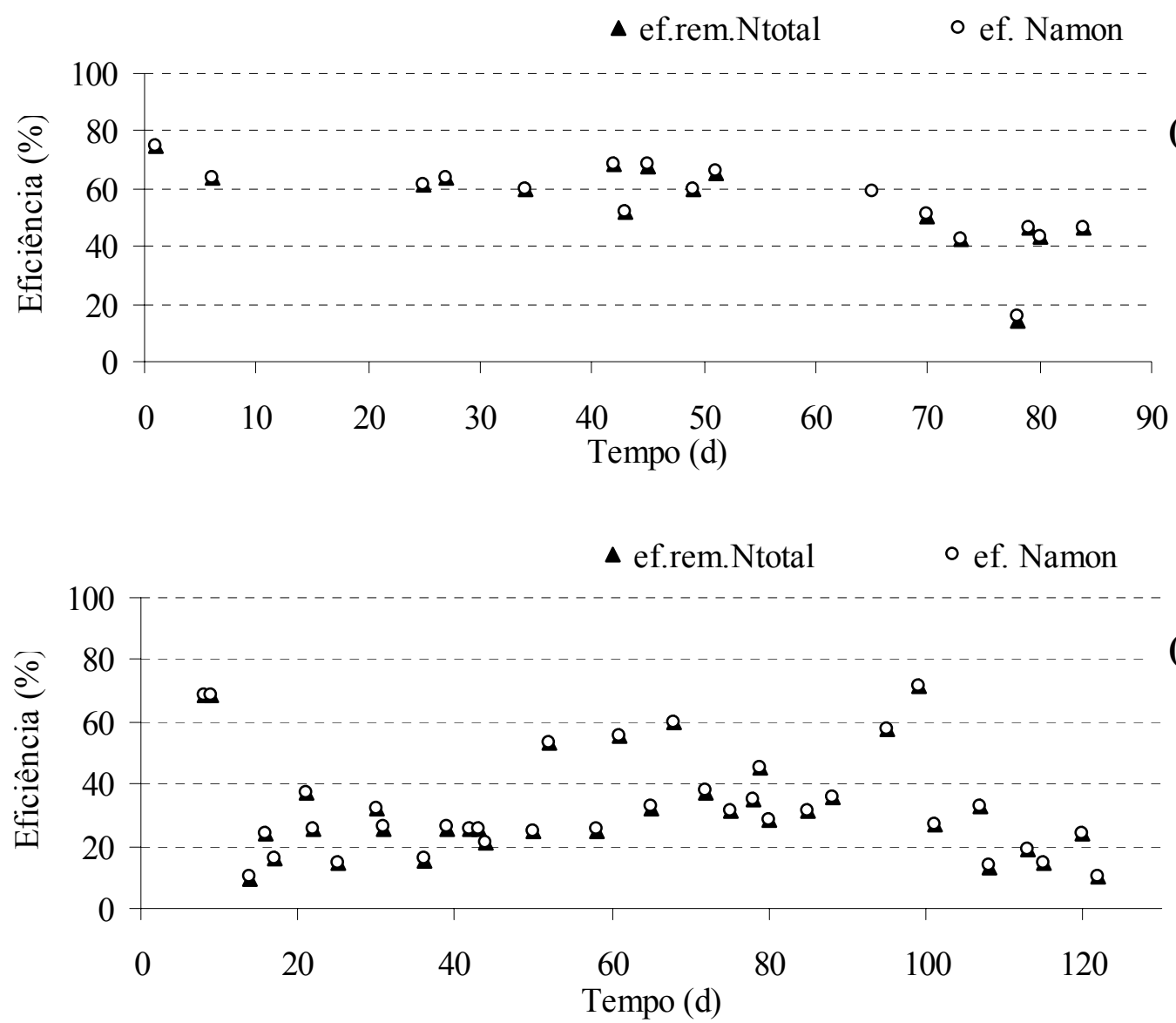

(b)

Figura 5.28 - Eficiências de remoção de nitrogênio durante a condição operacional de $500 \mathrm{mg}$

$\mathrm{N} / \mathrm{L}$, ciclos anóxicos/aeróbios de $2 \mathrm{~h} / 2 \mathrm{~h}$, sob duas condições de concentração de oxigênio dissolvido: (a) OD média de 2,9 $\mathrm{mg} \mathrm{O}_{2} / \mathrm{L} \mathrm{em} \mathrm{pH}$ afluente de 7,9; (b) OD média de 2,7 $\mathrm{mg} \mathrm{O}_{2} / \mathrm{L}$ em pH afluente de 7,7.

Mesmo com aumento significativo da concentração de OD e da duração do período aeróbio, o reator não obteve boa eficiência de remoção de nitrogênio (Tabela 5.6 e Figuras 5.29a e 5.29b). Alleman (1985) e Katsogiannis et al. (2003) relataram que a duração curta do período aeróbio motivou o acúmulo de nitrito em seus experimentos 
com RBS (Quadro 3.6). Alleman (1985) obteve acúmulo de nitrito com biomassa em suspensão em tempos de $3 \mathrm{~h}$ de aeração enquanto que nitrato predominou em períodos de 5 e 9h de duração. Katsogiannis et al. (2003) obteve nitrificação curta em biomassa em suspensão com a aplicação de batelada de $6 \mathrm{~h}$ dividida em três ciclos aeróbios/anóxicos de $20 \mathrm{~min} / 60 \mathrm{~min}$.
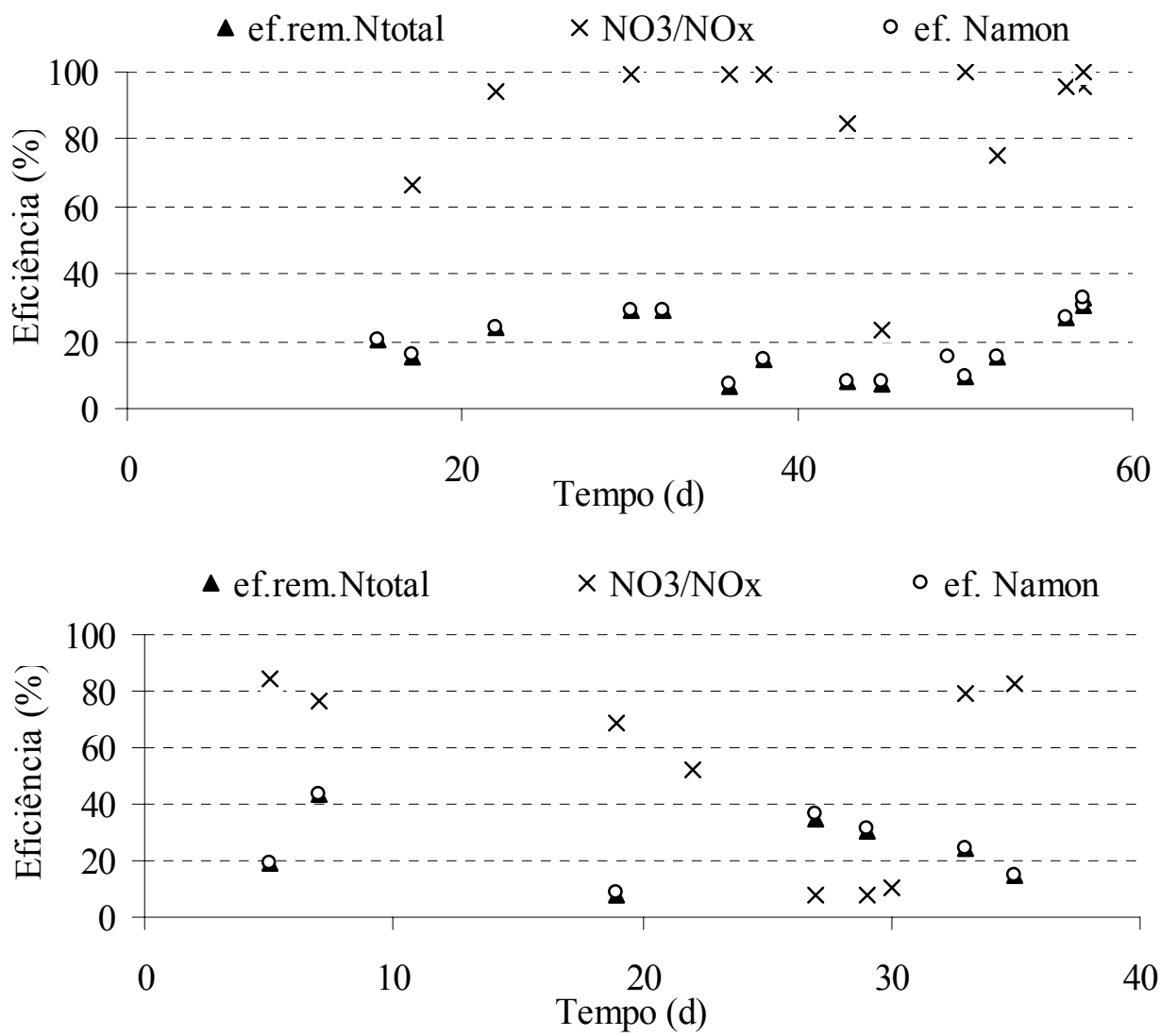

Figura 5.29 - Eficiências de remoção de nitrogênio durante a condição operacional de $500 \mathrm{mg}$

$\mathrm{N} / \mathrm{L}$, ciclos anóxicos/aeróbios de $2 \mathrm{~h} / 4 \mathrm{~h}$, sob duas condições de concentração de oxigênio dissolvido: (a) OD média de 3,2 $\mathrm{mg} \mathrm{O}_{2} / \mathrm{L} \mathrm{em} \mathrm{pH}$ afluente de 7,6; (b) OD média de 4,3 $\mathrm{mg} \mathrm{O}_{2} / \mathrm{L}$ em $\mathrm{pH}$ afluente de 7,7 .

Como a biomassa estava na forma suspensa, o descarte de efluente não era totalmente eficiente, com residual de formas nitrogenadas no lodo. Ao longo do experimento, com a eficiência de remoção de nitrogênio baixa (em torno de 20\%), a água intersticial do lodo no início de cada batelada já continha determinada concentração de $\mathrm{N}$-amoniacal, a qual, adicionada àquela da batelada alimentada, atingia concentração de amônia livre que a biomassa suspensa não foi capaz de oxidar. Foi feito um teste para se verificar se a biomassa havia perdido sua atividade nitrificante. $\mathrm{O}$ substrato foi diluído e a biomassa foi submetida a três bateladas de $24 \mathrm{~h}$ de aeração e logo após o programa de quatro ciclos anóxicos/aeróbios. O nitrito resultou como principal produto da nitrificação e a eficiência de remoção de nitrogênio aumentou 
significativamente (Figura 5.29b). Isso significa que a duração do ciclo aeróbio era insuficiente. O próximo passo foi aumentar a duração do ciclo de aeração de $4 \mathrm{~h}$ para $9 \mathrm{~h}$.

$\mathrm{O}$ aumento da concentração de nitrito no efluente, conforme observado na Figura 5.29b, foi aparentemente provocado pelo aumento da concentração de OD no reator, com relativo aumento da eficiência de remoção. Isso também pode indicar que o reator já estava se adaptando à condição de nitrificação via nitrito, como foi verificado na mudança de operação seguinte - $\mathrm{pH} 8$, concentração média de OD de $2,8 \mathrm{mg} / \mathrm{L} \mathrm{O}_{2} \mathrm{e}$ ciclo anóxico/aeróbio de $2 \mathrm{~h} / 9 \mathrm{~h}$ (Figuras 5.30 e 5.31). Durante o período que compreendeu os dados de 43 a 63 d, não foi possível coletar os dados, pois referem-se ao período de qualificação e de recesso do laboratório no final do ano.

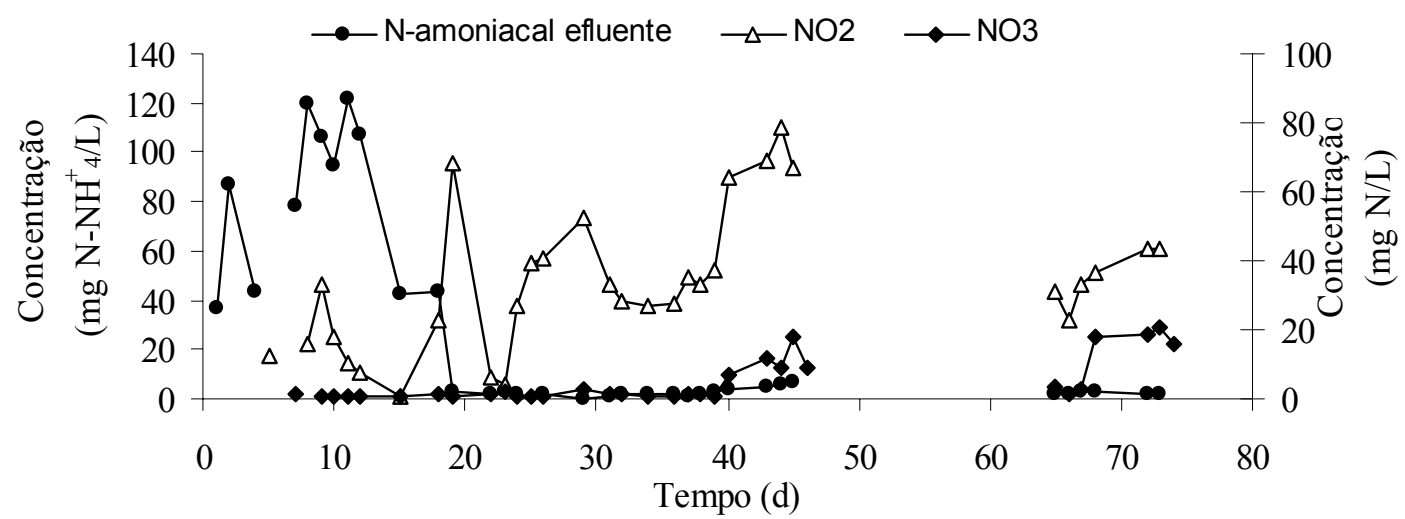

Figura 5.30 - Concentrações resultantes das formas de nitrogênio no efluente durante a condição operacional de $500 \mathrm{mg} \mathrm{N} / \mathrm{L}$ sob concentração média de OD de $2,8 \mathrm{mg} \mathrm{O}_{2} / \mathrm{L}$,em pH afluente de 8 e sob 2 ciclos anóxicos/aeróbios de $2 \mathrm{~h} / 9 \mathrm{~h}$.

Observa-se pela Figura 5.31 que nitrito é a forma predominantes das formas oxidadas $(80 \%)$.

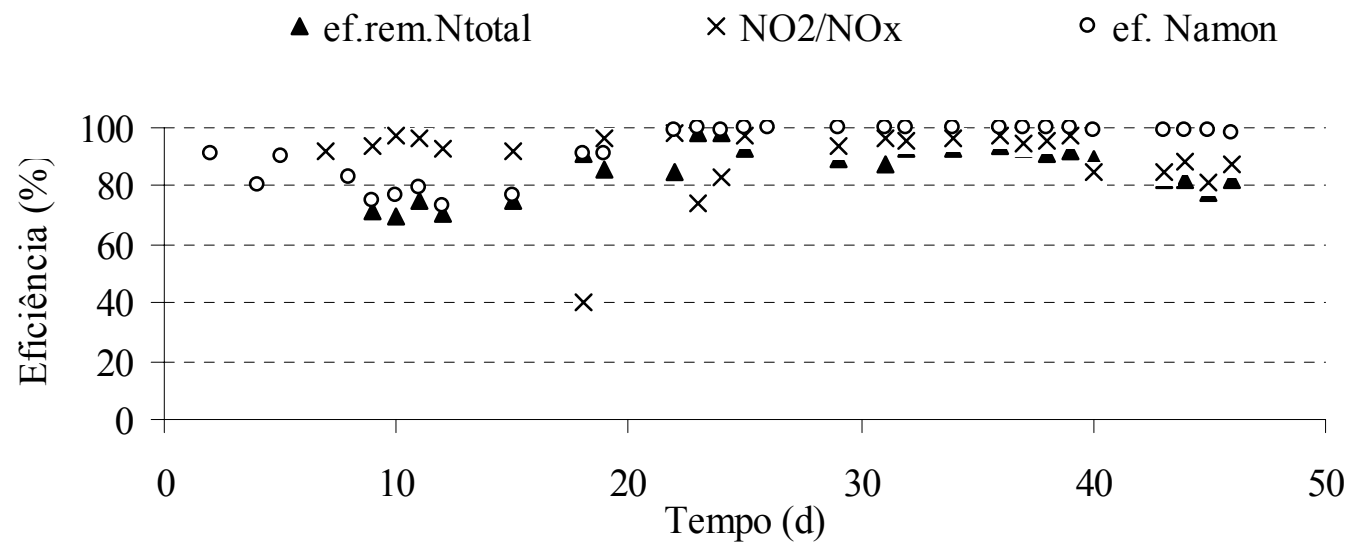

Figura 5.31 - Eficiências de remoção de nitrogênio durante a condição operacional de $500 \mathrm{mg}$ $\mathrm{N} / \mathrm{L}$ sob concentração média de OD de $2,8 \mathrm{mg} \mathrm{O} / 2$,em pH afluente de 8 e sob 2 ciclos anóxicos/aeróbios de $2 \mathrm{~h} / 9 \mathrm{~h}$. 
A análise microbiológica do lodo nessa condição operacional de $\mathrm{N}$-amoniacal pode ser observada pelas imagens da Figura 5.32 Foram observadas bactérias semelhantes às acumuladoras de fósforo (inclusões de polifosfato), cocos, bacilos, organismos zoogloeiais, protozoários (flagelados, ciliados pedunculados e cistos), metazoários (rotíferos e nematóides).
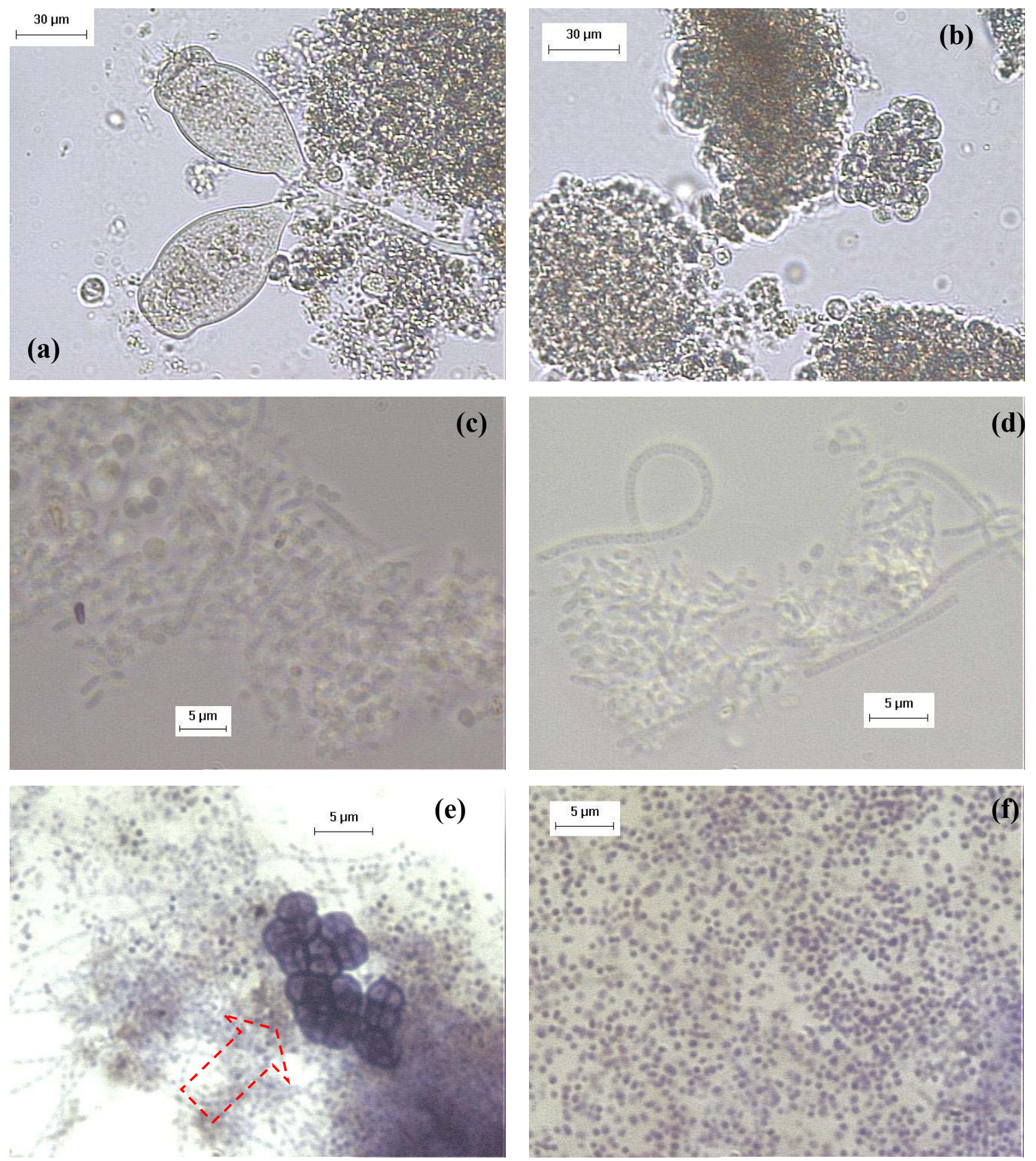

Figura 5.32 - Microfotografias do final da condição operacional de $500 \mathrm{mg}$ N/L, com concentração média de OD média de $2,8 \mathrm{mg} \mathrm{O} \mathrm{O}_{2} / \mathrm{L}$. (a) ciliados pedunculados; (b) cistos de protozoários; (c) cocos e bacilos; (d) bacilos e filamentos; (e) e (f) bactérias acumuladoras de fósforo (coloração de Neisser).

Foram identificadas bactérias acumuladoras de fósforo pela coloração de grânulos de polifosfato na condição operacional de 500mg N/L. Segundo Jenkins et al. 
(2003), bactérias acumuladoras de fósforo ocorrem em sistemas com zonas iniciais anóxicas ou anaeróbias em sistemas de lodos ativados. As células isoladas (Figura 5.32f) e as arranjadas como "cachos de uva", (Figura 5.32e) coradas com a metodologia de Neisser, estão associadas a grânulos de polifosfato inorgânicos estocados internamente, que se acumulam quando estes organismos são submetidos a ambiente anóxico/ aeróbio.

Segundo NICHOLLS e OSBORN ${ }^{7}$ (1979) apud SOUSA (1996), quando as bactérias são temporariamente privadas de um ou mais elementos essenciais (nitrogênio, fósforo, enxofre ou oxigênio), como em ambientes alternados anóxicos/aeróbios, podem sucumbir, enquanto outras são capazes de usar vias metabólicas alternativas. Um mecanismo particular de sobrevivência de algumas bactérias é a capacidade de estocar o fósforo na forma de polifosfato e o carbono na forma de poli- $\beta$-hidroxibutirato (PHB) e glicogênio (ALLEMAN e IRVINE, 1980; JENKINS et al., 2003).

Essas células são encontradas em grande número em sistemas de remoção biológica de fósforo. Essa coloração e a forma tetraédrica (Figura 5.32e) são características de "bactérias G", que também estão associadas com sistemas de lodos ativados que contém zonas iniciais anóxicas/ anaeróbias e onde não ocorre remoção de fósforo. Essas bactérias foram observadas por Cech e Hartman ${ }^{8}$ (1993) apud Jenkins et al. (2003) em sistema de lodos ativados anaeróbio/ aeróbio alimentado com glicose. Estes organismos podem, aparentemente, tomar e estocar substrato solúvel anoxicamente sem a ciclagem de fosfato e estocagem de polifosfato inorgânico. Essas bactérias têm sido encontradas em sistemas de remoção de fósforo, onde esses sistemas cessaram de funcionar ou funcionam inadequadamente.

Adicionalmente, foram retiradas amostras de lodo nas paredes e fundo do reator, que visualmente apresentavam massa polimérica gelatinosa aderida aos mesmos. As bactérias observadas ao microscópio apresentavam a mesma morfologia do lodo em suspensão.

\footnotetext{
${ }^{7}$ NICHOLLS OSBORN, apud SOUSA, J.T. (1996). Pós tratamento de efluente de reatores anaeróbios de fluxo ascendente em reator aeróbio seqüencial em batelada e coluna de lodo anaeróbio para desnitrificação. 258p. Tese (doutorado) - Escola de Engenharia de São Carlos, Universidade de São Paulo ,São Carlos. 1996.

8 CECH, J.S.; HARTMAN, P. (1993). Competition between poliphosphate and polyssacharide accumulating bactéria in enhanced biological phosphate removal systems. Water Research, v.13, p.1213 apud JENKINS, D.; RICHARD, M.G.; DAIGGER, G.T. (2003). Manual on the causes and control of activated sludge bulking, foaming, and other solids separation problems. $3^{\text {rd }}$ ed. Boca Raton: Lewis Publishers.
} 


\subsubsection{Obtenção do perfil temporal - análise de uma batelada de $24 \mathrm{~h}$}

Foram elaborados os gráficos de variação temporal das concentrações de Namoniacal durante a condição operacional de $500 \mathrm{mg} \mathrm{N} / \mathrm{L}$, sob ciclos anóxicos /aeróbios de 2h/9h, em concentração média de $\mathrm{OD}$ de $2,8 \mathrm{mg} \mathrm{O}_{2} / \mathrm{L}$ e $\mathrm{pH}$ afluente de 8 , apresentado na Figura 5.33a e 5.33b.

A concentração de $\mathrm{N}$-amoniacal inicial nos ciclos anóxicos continuou menor do que a concentração adicionada de $500 \mathrm{mg} \mathrm{N} / \mathrm{L}$, numa proporção relativa à diluição e batelada alimentada. Nitrito e nitrato foram produzidos durante as $9 \mathrm{~h}$ do período aeróbio, com predominância de nitrito (Figuras 5.30 e 5.31). Observando-se a Figura 5.33a, todo o $\mathrm{N}$-amoniacal foi removido em 6 h de aeração no primeiro período aeróbio, com menor tempo no segundo período aeróbio. Aos 71 dias, o $\mathrm{N}$-amoniacal foi removido em 8 h, porém com tempo de 6 h para a remoção de $\mathrm{N}$-amoniacal no segundo período aeróbio, provavelmente devido ao efeito da aeração intermitente.
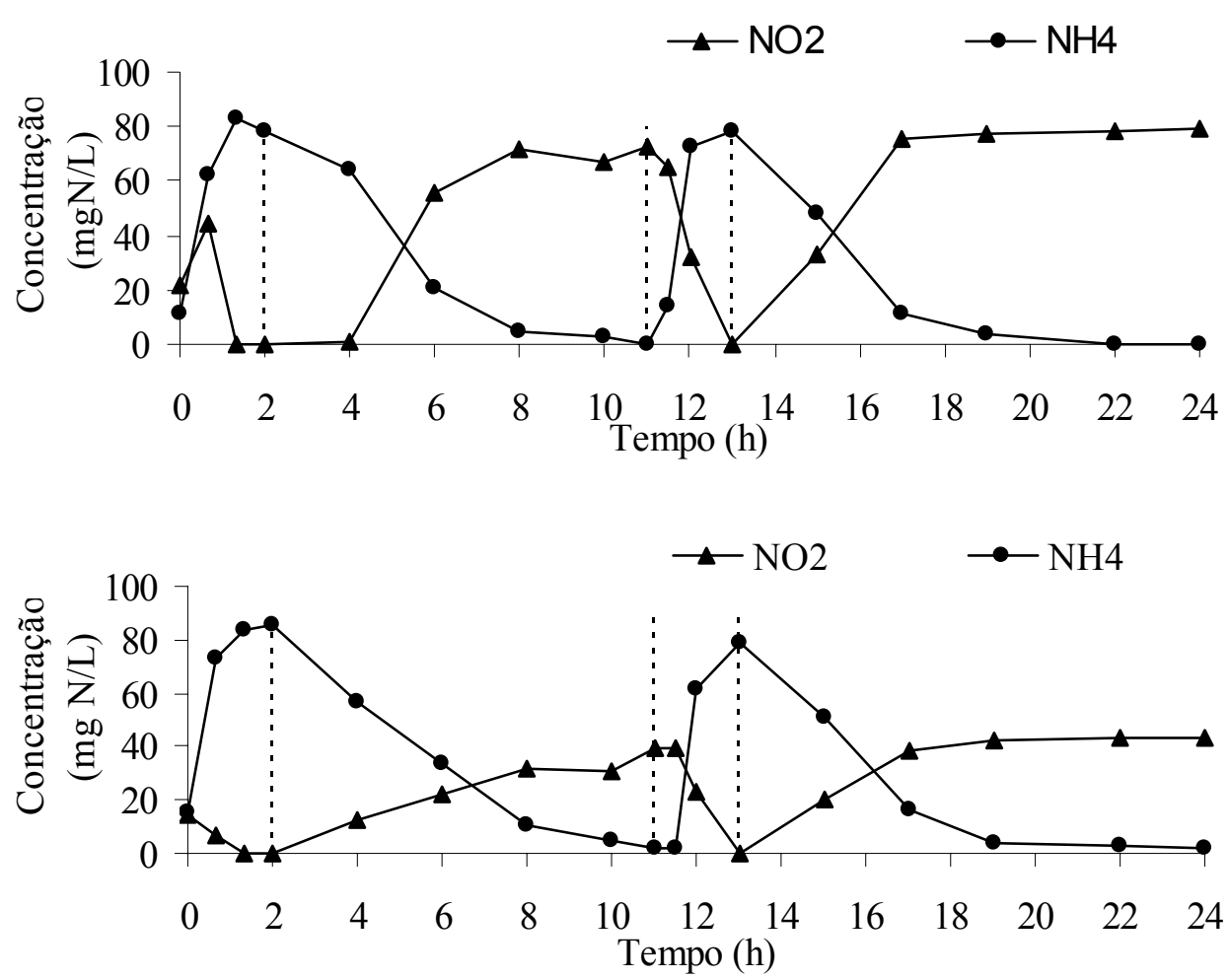

(b)

Figura 5.33 - Variação temporal das concentrações de nitrito e N-amoniacal durante a condição operacional de $500 \mathrm{mg} \mathrm{N} / \mathrm{L}$ sob concentração de OD de 2,8 $\mathrm{mg} \mathrm{O}_{2} / \mathrm{L}$,em pH afluente de 8 e sob 2 ciclos anóxicos/aeróbios de 2h/9h: (a) aos 43 dias; (b) aos 71 dias de experimento.

A soma das formas oxidadas de nitrogênio foi igual ao $\mathrm{N}$-amoniacal consumido, 
o que configura que não houve NDS, como ocorreu na condição operacional de $250 \mathrm{mg}$ N/L. As concentrações das formas oxidadas nos períodos aeróbios sempre estiveram em concentrações maiores que as concentrações de N-amoniacal afluentes (Figura 5.34).
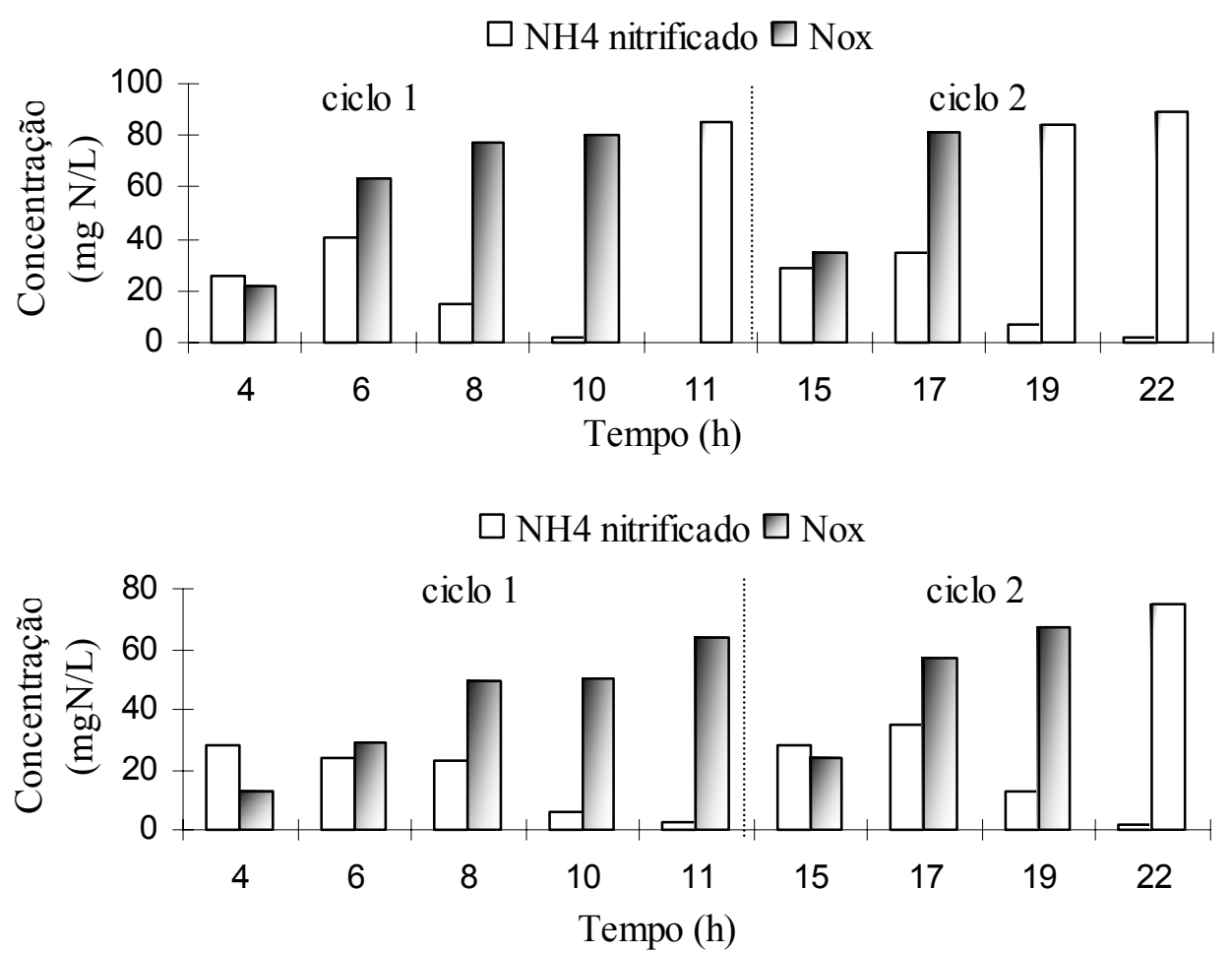

Figura 5.34. Concentrações das formas de nitrogênio durante os períodos aeróbios durante a condição operacional de $500 \mathrm{mg} \mathrm{N} / \mathrm{L}$ : (a) aos 43 dias e (b) aos 71 dias de experimento.

Os valores de concentração de amônia livre, no início dos ciclos aeróbios (Figura 5.35) foram acima das concentrações relatadas em literatura como inibitórias (1 a $5 \mathrm{mg} \mathrm{N}-\mathrm{NH}_{3} / \mathrm{L}$ ), justificando em parte a predominância de nitrito.

As concentrações de nitrito, aos 71 dias de experimento, foram menores que aos 43 dias de experimento, porém, sua variação mostrou a mesma tendência de consumo de $\mathrm{N}$-amoniacal e produção de nitrito e nitrato (Figuras 5.33a e b).

Essa condição de operação de último ciclo aeróbio foi delineada com a finalidade de facilitar o acompanhamento das formas oxidadas de nitrogênio no efluente. Como pode ser visto na Figura 5.33a e 5.33b, o efluente continha elevadas concentrações de nitrito e nitrato, resultantes do último ciclo aeróbio, que ainda precisavam ser desnitrificadas, pois não atingem os padrões de lançamento de esgotos em corpos de água, com risco de provocarem impactos ambientais como eutrofização, metemoglobinemia e outros. 


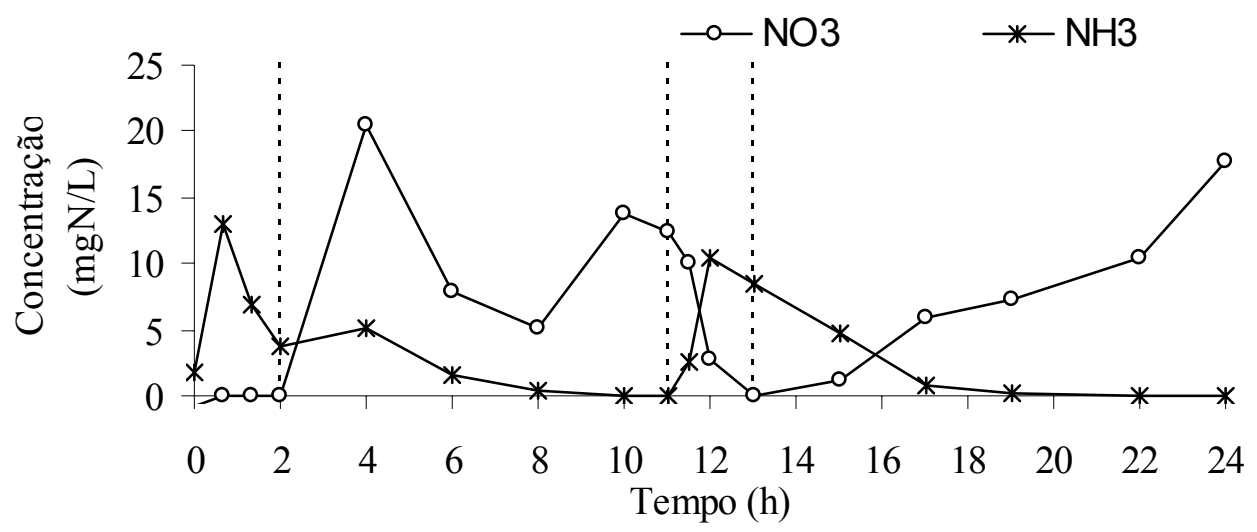

(a)

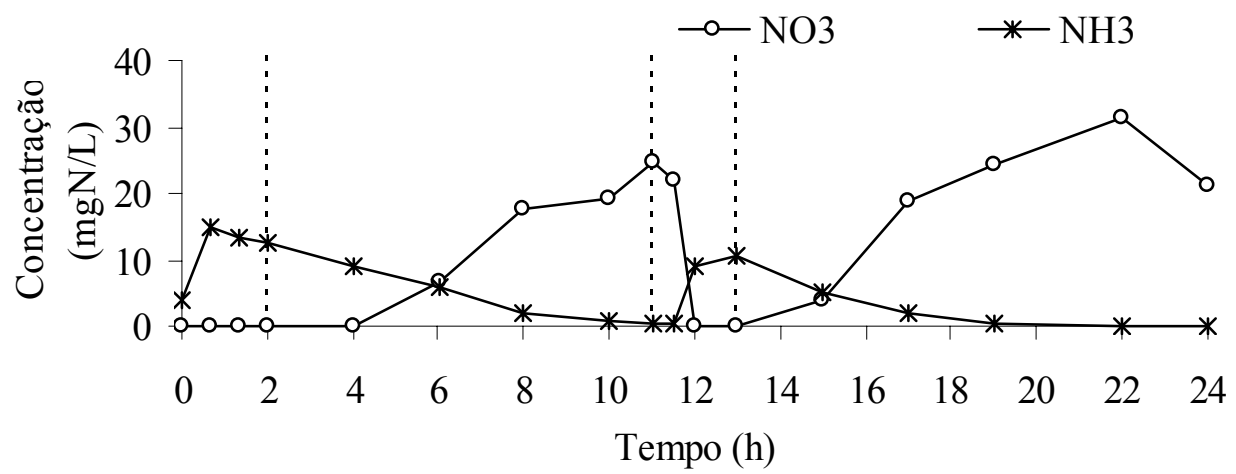

(b)

Figura 5.35 - Variação temporal das concentrações de nitrato e de amônia livre durante

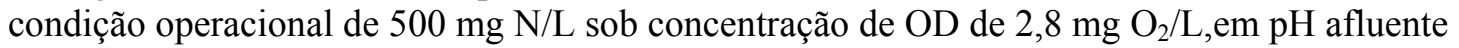
de 8 e sob 2 ciclos anóxicos/aeróbios de 2h/9h: (a) aos 43dias; (b) aos 71 dias de experimento.

\subsection{2 - Variação dos valores de pH}

O pH no efluente, durante a condição operacional de $500 \mathrm{mg} \mathrm{N} / \mathrm{L}$, concentração média de $\mathrm{OD}$ de $2,9 \mathrm{mg} \mathrm{O}_{2} / \mathrm{L}$ esteve ao redor de 8,5 (Figura 5.36a), enquanto que o $\mathrm{pH}$ no efluente esteve ao redor de 7,5 em concentração de OD de $2,7 \mathrm{mg} \mathrm{O}_{2} / \mathrm{L}$ e pH afluente de 7,5 (Figura 5.36b), demonstrando que um decréscimo no $\mathrm{pH}$ afluente pode afetar o pH efluente, sem afetar a estabilidade do processo.

Resultados mais favoráveis de $\mathrm{pH}$ efluente foram obtidos para a condição (a) (Figura 5.36a), em que o pH manteve-se ao redor de 8,5, pois a alcalinidade adicionada no afluente de $3 \mathrm{~g} \mathrm{NaHCO}_{3} / \mathrm{L}$ também foi maior que na condição (b) (alcalinidade adicionada de $1 \mathrm{~g} \mathrm{NaHCO}_{3} / \mathrm{L}$ ). Considerando-se temperatura de $25^{\circ} \mathrm{C}$ e $100 \mathrm{mg} \mathrm{N}$ $\mathrm{NH}_{4}^{+} / \mathrm{L}$, as concentrações de amônia livre no reator em $\mathrm{pH} 7,6$ e 7,8 são respectivamente 4,2 e $2,69 \mathrm{mg} \mathrm{N}-\mathrm{NH}_{3} / \mathrm{L}$, o que significa redução de $36 \%$ na concentração de amônia livre. Levando em conta que a amônia livre é inibitória tanto às 
bactérias oxidantes de $\mathrm{N}$-amoniacal quanto às oxidantes de nitrito, uma diminuição no $\mathrm{pH}$ afluente pode ser interessante.
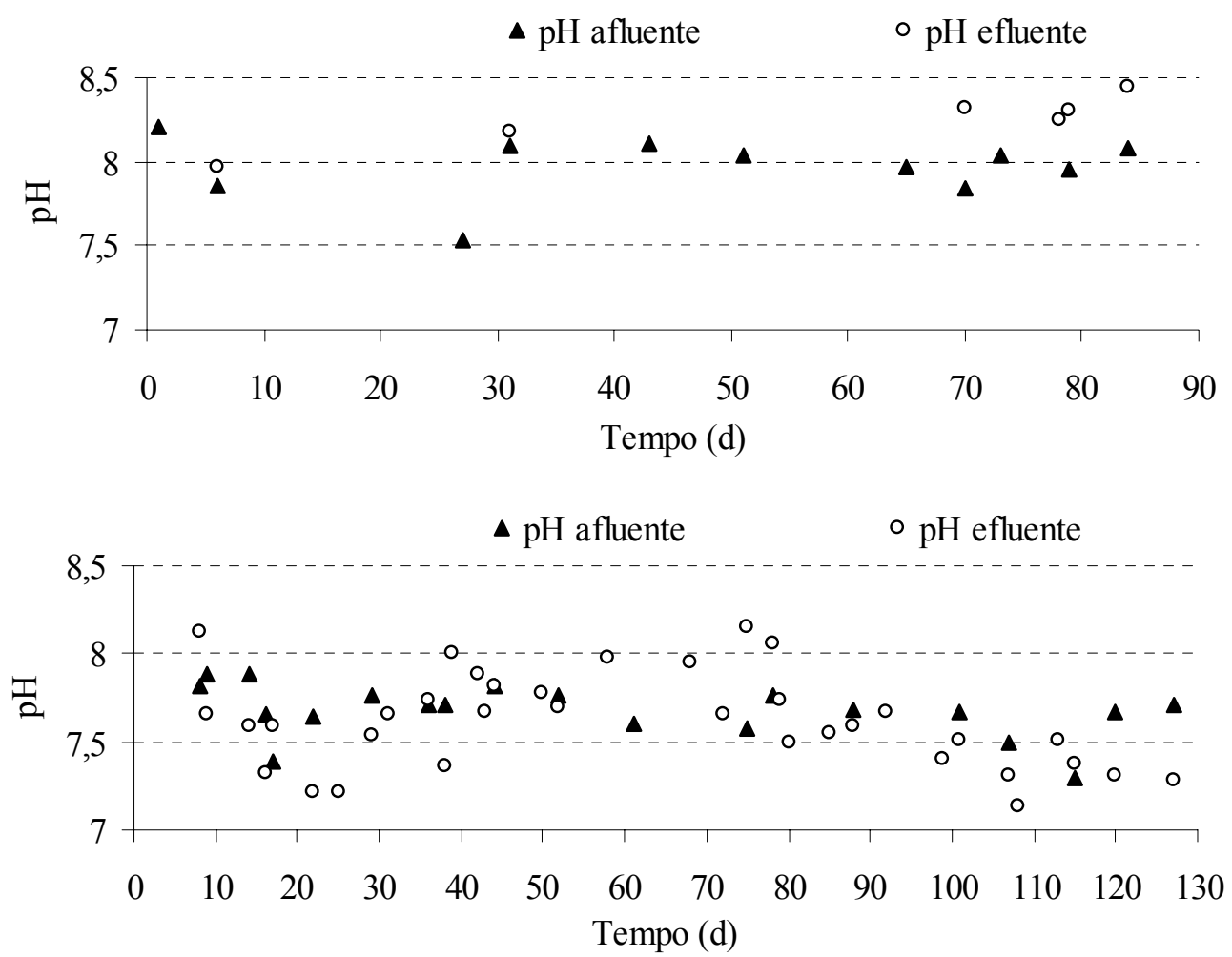

(b)

Figura 5.36 - Variação dos valores de pH durante a condição operacional de $500 \mathrm{mg} \mathrm{N} / \mathrm{L}$, ciclos anóxicos/aeróbios de $2 \mathrm{~h} / 2 \mathrm{~h}$ sob duas condições de concentração de oxigênio dissolvido:( a) OD média de 2,9 $\mathrm{mg} \mathrm{O}_{2} / \mathrm{L}$ e pH afluente de 7,9 e (b) OD média de 2,7 $\mathrm{mg} \mathrm{O}_{2} / \mathrm{L}$ e pH afluente de 7,7.

Com um aumento na concentração de OD e pH afluente de 7,6 (Figura 5.37), o $\mathrm{pH}$ efluente esteve ao redor de 7,5 (Figura 5.37a). Enquanto que o pH efluente atingiu resultados similares aos observados para a condição em que a concentração média de OD foi de 4,3 $\mathrm{mg} \mathrm{O}_{2} / \mathrm{L} \mathrm{e} \mathrm{pH}$ afluente foi de 7,7 (Figura 5.37b).

$\Delta \mathrm{pH}$ afluente $\quad \circ \mathrm{pH}$ efluente

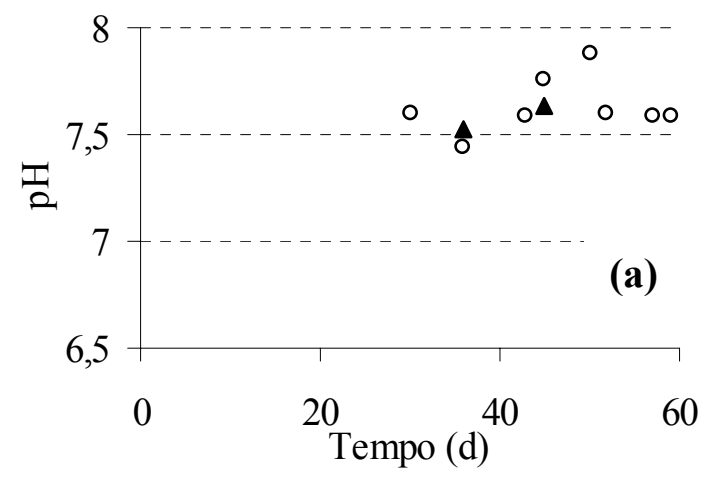

$\Delta \mathrm{pH}$ afluente $\quad \circ \mathrm{pH}$ efluente

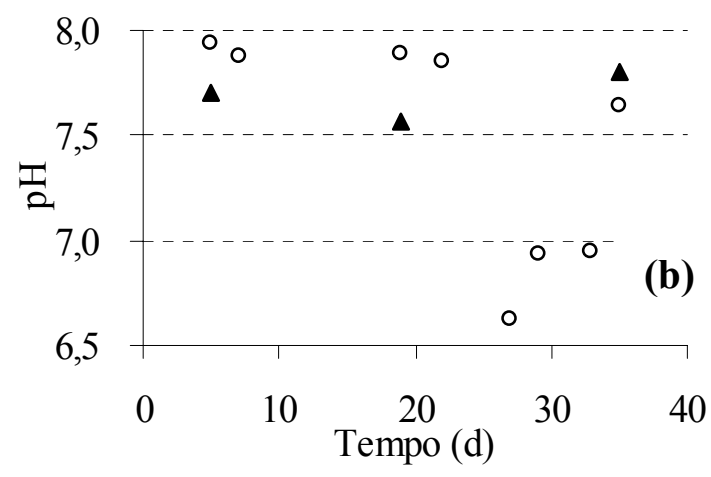

Figura 5.37 - Variação dos valores de pH durante a condição operacional de $500 \mathrm{mg} \mathrm{N} / \mathrm{L}$, ciclos anóxicos/aeróbios de $2 \mathrm{~h} / 4 \mathrm{~h}$, sob duas condições de concentração de oxigênio dissolvido: (a) OD média de 3,2 $\mathrm{mg} \mathrm{O}_{2} / \mathrm{L} \mathrm{e} \mathrm{pH}$ afluente de 7,6 e (b) OD média de 4,3 $\mathrm{mg} \mathrm{O}_{2} / \mathrm{L}$ e pH afluente de 7,7. 
A operação em concentração maior de $\mathrm{OD}(4,3 \mathrm{mg} \mathrm{O} / \mathrm{L})$ teve eficiência de remoção de nitrogênio um pouco maior que na concentração anterior, com valores resultantes de $\mathrm{pH}$ no efluente semelhantes. Concentrações maiores de nitrito ocorreram com a diminuição do pH (em valores menores que 7 - Figura 5.37b).

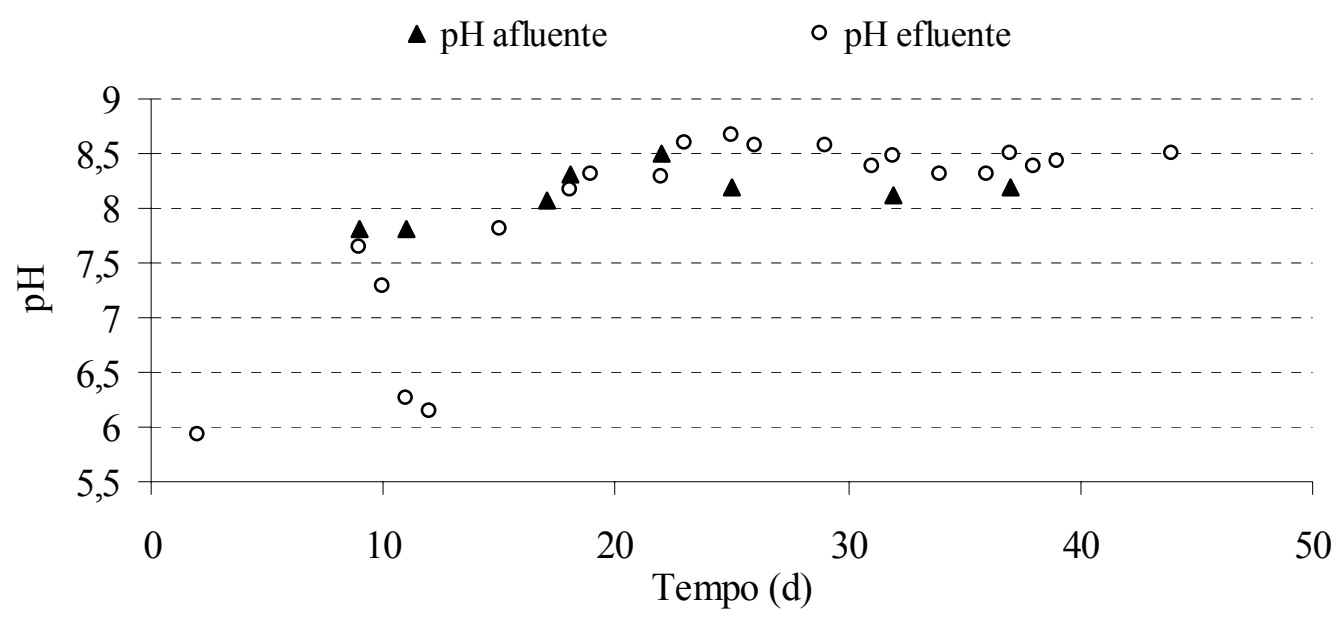

Figura 5.38 - Variação dos valores de pH durante a condição operacional de $500 \mathrm{mg} \mathrm{N} / \mathrm{L}$ sob

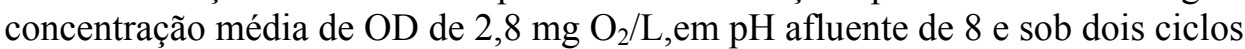
anóxicos/aeróbios de $2 \mathrm{~h} / 9 \mathrm{~h}$.

\subsection{3 - Potencial redox e oxigênio dissolvido}

Na Figura 5.39 é apresentada a variação dos valores de potencial redox e de concentração de OD durante uma batelada de $24 \mathrm{~h}$ compreendendo os dois ciclos anóxico/aeróbios. Os valores de potencial redox eram inicialmente baixos (ao redor de $150 \mathrm{RmV}$ ) e acompanharam as mudanças nas concentrações de OD.

As primeiras horas ( 3 a $4 \mathrm{~h}$ ) de cada período aeróbio apresentaram concentração média de $\mathrm{OD}$ de $1 \mathrm{mg} \mathrm{O}_{2} / \mathrm{L}$, com súbito aumento (variação de $2 \mathrm{mg} \mathrm{O}_{2} / \mathrm{L} \mathrm{em} 37 \mathrm{~min}$ ) para $3 \mathrm{mg} \mathrm{O} / \mathrm{L}$. Tal mudança não resultou em aumento abrupto dos valores de potencial redox. Os valores de potencial redox durante os períodos aeróbios permaneceram abaixo de $+100 \mathrm{RmV}$. Nos períodos aeróbios, ao se atingir a concentração controle de $3 \mathrm{mg}$ $\mathrm{O}_{2} / \mathrm{L}$, o potencial redox também atingiu dois patamares: 48 a $55 \mathrm{RmV}$ ( $\mathrm{t}=6,5$ às $8 \mathrm{~h}$ ) no primeiro período aeróbio e de $90 \mathrm{RmV}$ ( $\mathrm{t}=18$ às $20 \mathrm{~h}$ ) no segundo período aeróbio aos 43 dias. 


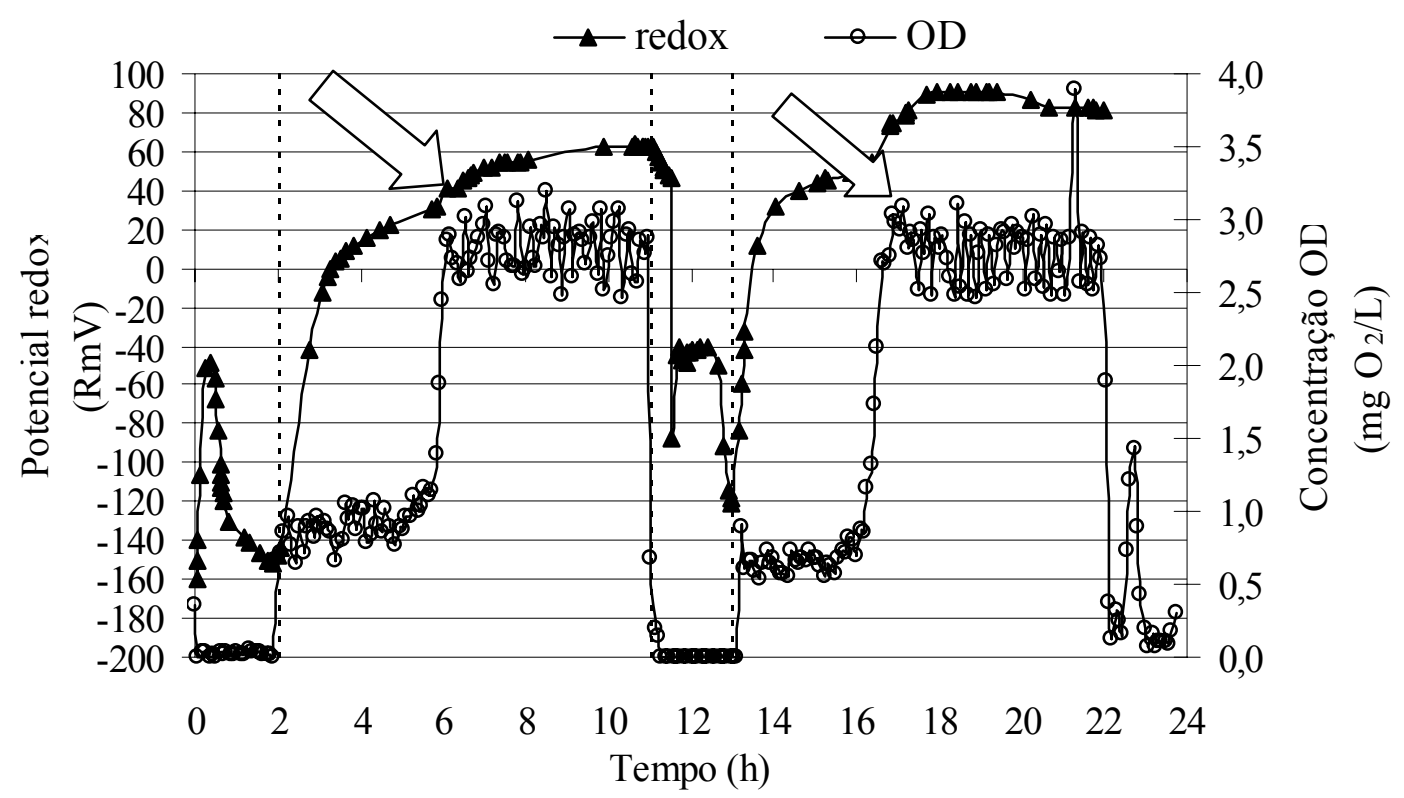

Figura 5.39 - Variação temporal dos valores de potencial redox e das concentrações de OD durante condição operacional de $500 \mathrm{mg} \mathrm{N} / \mathrm{L}$ aos 43 dias.

A repetição do monitoramento da variação temporal da Figura 5.40 apresentou comportamento semelhante, porém, nesse caso, provavelmente a vazão de ar deveria

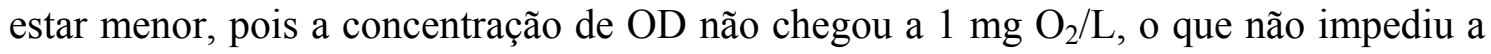
nitrificação de ocorrer (Figura 5.33b), com predominância de nitrito. Somente quando a concentração de OD atingia valor maior que zero, o valor de potencial redox sofreu mudança da inclinação para o eixo positivo.

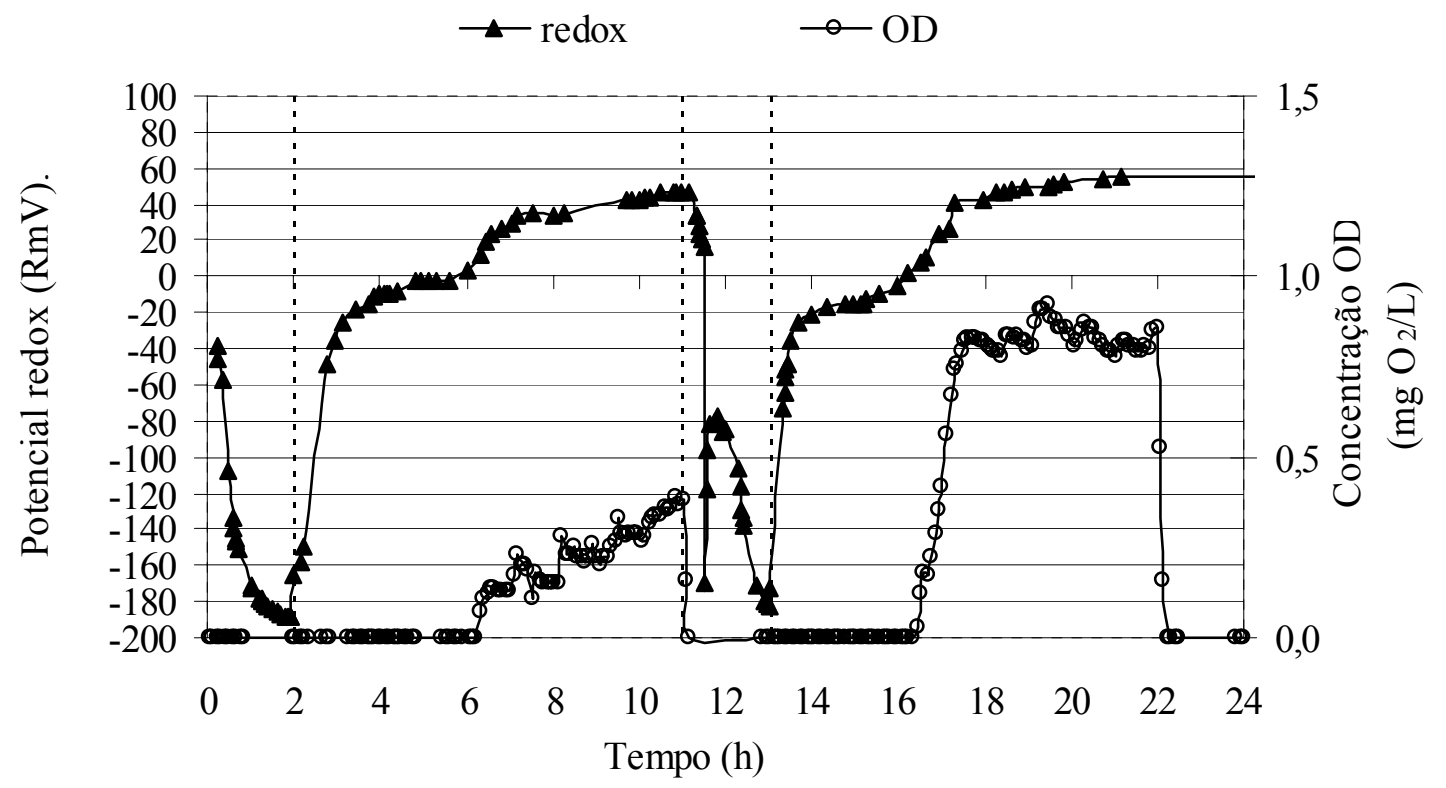

Figura 5.40 - Variação temporal dos valores de potencial redox e das concentrações de OD durante a condição operacional de $500 \mathrm{mg} \mathrm{N} / \mathrm{L}$ aos 71 dias. 


\subsection{4 - Perfil temporal de um ciclo anóxico/ aeróbio de $2 \mathrm{~h} / 9 \mathrm{~h}$}

Realizou-se ensaio de $11 \mathrm{~h}$ com amostras retiradas a cada $1 \mathrm{~h}$ durante o primeiro ciclo anóxico/aeróbio, com a análise dos seguintes parâmetros: potencial redox, nitrito, nitrato, N-amoniacal e oxigênio dissolvido (Figura 5.41).
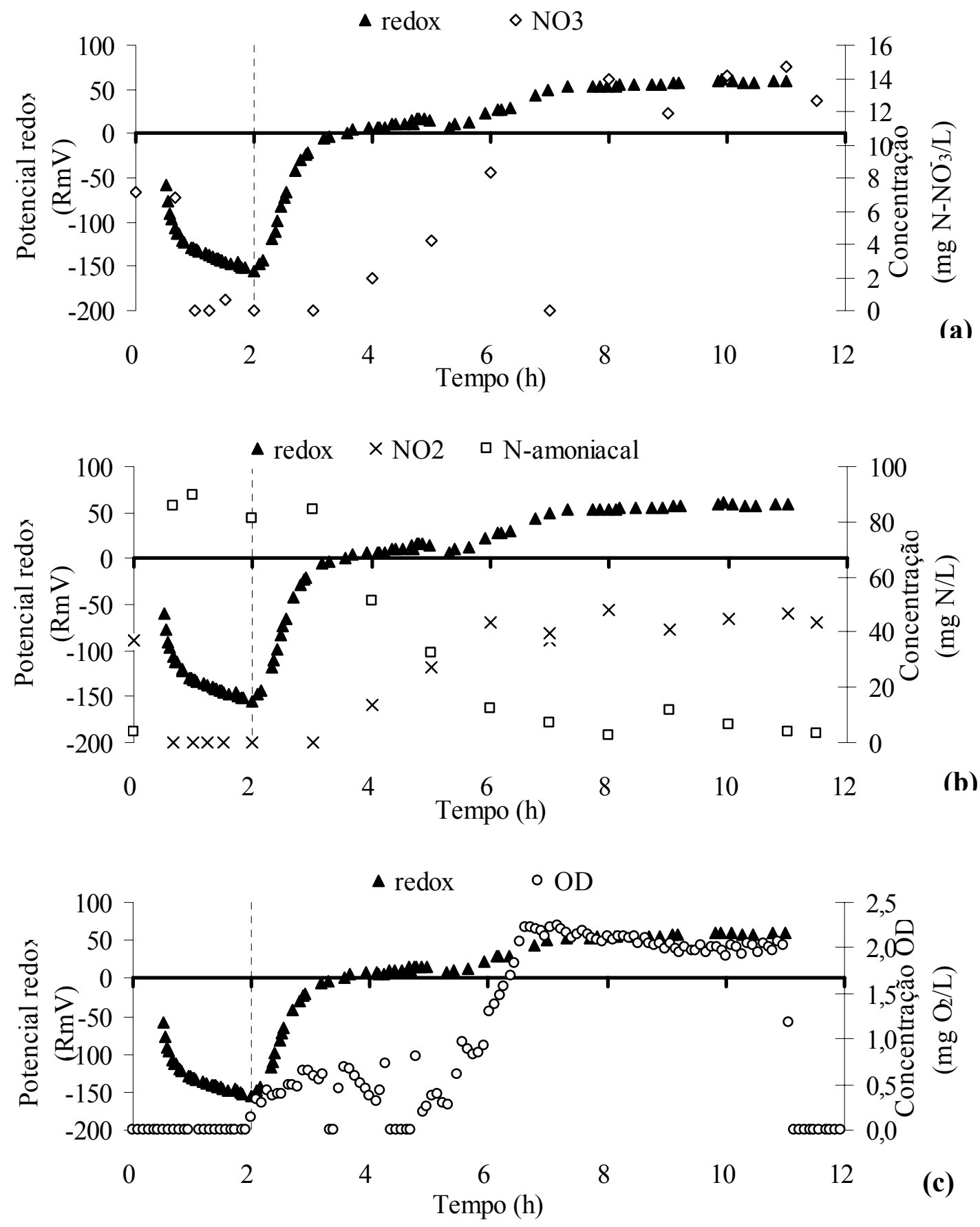

Figura 5.41 - Variação temporal dos parâmetros durante um ciclo anóxico/ aeróbio de $11 \mathrm{~h}$ durante a condição operacional de $500 \mathrm{mg} \mathrm{N} / \mathrm{L}$ em concentração média de OD de $2,8 \mathrm{mg} \mathrm{O}_{2} / \mathrm{L}$ : (a) potencial redox com concentrações de nitrato; (b) potencial com concentrações de nitrito e $\mathrm{N}$-amoniacal; (d) potencial redox com concentrações de OD. 
O valor de potencial redox durante o período aeróbio teve aumento inicial resultante do acionamento dos aeradores. Os valores de potencial redox apresentaram dois patamares que acompanharam os dois patamares na concentração de OD $(\mathrm{t}=2 \mathrm{~h}$ a $6 \mathrm{~h}$ e $\mathrm{t}=6 \mathrm{~h}$ a $\mathrm{t}=10 \mathrm{~h}$; Figura 5.41d).

$\mathrm{O}$ consumo de $\mathrm{N}$-amoniacal no período aeróbio coincidiu com a mudança da concentração de oxigênio dissolvido (Figuras 5.41c e 5.41d). Quando a concentração de $\mathrm{N}$-amoniacal aproximou-se de zero, a concentração de OD apresentava mudança abrupta de direção, com variação significativa, como pode ser visto no tempo $t=6,5 \mathrm{~h}$. Quando $\mathrm{t}=8 \mathrm{~h}$, a concentração de N-amoniacal obtida é de $2,4 \mathrm{mg} \mathrm{N} / \mathrm{L}$ e dPOR/dt=zero.

Com relação às formas oxidadas de nitrogênio, os valores de potencial redox diminuíram conforme houve redução de nitrato e nitrito, remanescentes da batelada anterior. A concentração de $40 \mathrm{mg} \mathrm{N}-\mathrm{NO}_{2}{ }^{-} / \mathrm{L}$ foi rapidamente desnitrificada no início da batelada, enquanto que no período aeróbio subseqüente, nitrito foi novamente

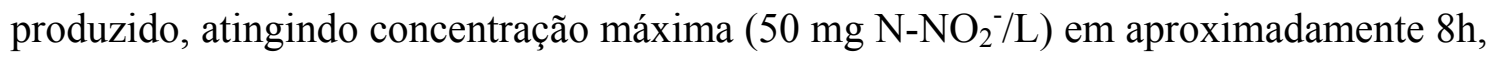
quando a variação de potencial redox era mínima ( $\Delta$ menor que $2 \mathrm{RmV}$ - Figura 5.41b).

Segundo Cho et al. (2001), como não há mudança nas condições dos estados oxidativos de nitrogênio durante o final do período anóxico de $9 \mathrm{~h}$, os valores de potencial redox tendem a se estabilizar. Esse autor também não conseguiu detectar o fim da desnitrificação com a mudança abrupta de inclinação do potencial redox, porém, ao se examinar a dPOR/dt (Figura 5.42), há pouca variação no $\mathrm{t}=1,0 \mathrm{~h}$, tanto o nitrito quanto o nitrato estão praticamente ausentes.

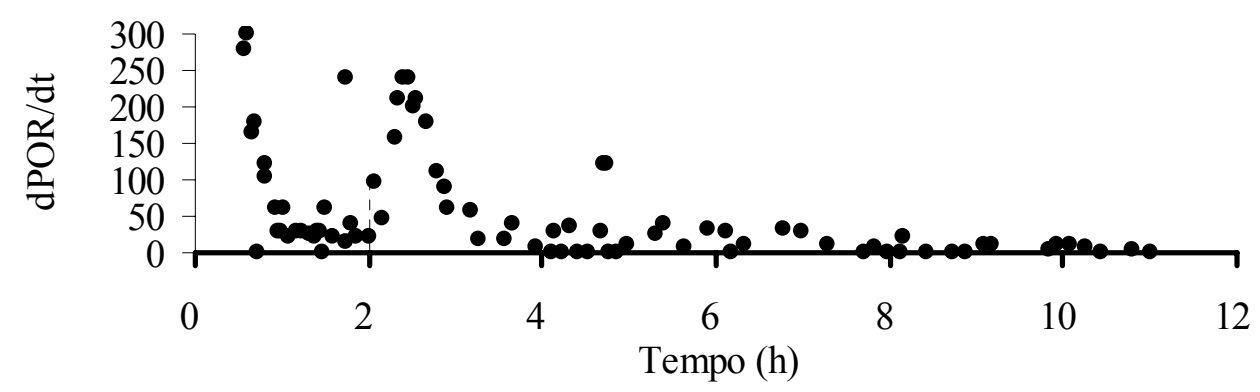

Figura 5.42. Variação dPOR/dt durante um ciclo anóxico/ aeróbio de 11 h durante a condição operacional de $500 \mathrm{mg} \mathrm{N} / \mathrm{L}$ em concentração média de OD de 2,8 $\mathrm{mg} \mathrm{O}_{2} / \mathrm{L}$.

Nesse caso, o parâmetro dPOR/dt não foi muito preciso (variação muito grande), pois apenas o dPOR foi suficiente para achar os pontos de início e término dos períodos aeróbios. Nessa concentração, o ciclo anóxico/aeróbio de $1 \mathrm{~h} / 8 \mathrm{~h}$ seria suficiente para a remoção de nitrogênio via nitrito. 


\section{5 - Velocidade de remoção de nitrogênio}

Para o cálculo da velocidade de utilização do substrato considerou-se o consumo de nitrogênio inorgânico como a soma das três formas de nitrogênio monitoradas: amoniacal, nitrito e nitrato no final do período aeróbio. Portanto a velocidade de remoção engloba as etapas de nitrificação e desnitrificação (Tabela 5.9).

Tabela 5.9 - Velocidade específica de remoção de nitrogênio das condições operacionais

\begin{tabular}{ccccccc}
$\begin{array}{c}\mathrm{N}- \\
\text { afluente } \\
(\mathrm{mg} \mathrm{N} / \mathrm{L})\end{array}$ & $\begin{array}{c}\mathrm{OD} \text { média } \\
\left(\mathrm{mO}_{2} / \mathrm{L}\right)\end{array}$ & $\begin{array}{c}\mathrm{N}- \\
\text { inorgânico } \\
(\mathrm{mg} / \mathrm{L})\end{array}$ & $\begin{array}{c}\text { Duração do } \\
\text { período } \\
\text { aerado }(\mathrm{h})\end{array}$ & $\begin{array}{c}\text { Velocidade } \\
\text { de remoção } \\
\text { de } \\
\text { nitrogênio } \\
(\mathrm{mg} \mathrm{N} / \mathrm{L} . \mathrm{h})\end{array}$ & $\begin{array}{c}\mathrm{SSV} \\
(\mathrm{g} / \mathrm{L})\end{array}$ & $\begin{array}{c}\text { Velocidade } \\
\text { específica } \\
\text { de remoção } \\
\text { de } \\
\text { nitrogênio } \\
\text { (mg N/g } \\
\text { SSV.L.h) }\end{array}$ \\
\hline 125 & 2 & 10 & 2 & 5 & 6,5 & 0,77 \\
& 1,5 & 10 & 2 & 5 & 5,8 & 0,86 \\
250 & $2 *$ & 10 & 2 & 5 & 4,4 & 1,15 \\
500 & 2,8 & $13,2-16$ & 2 & $6,6-8$ & 7,1 & $0,94-1,13$ \\
& $77-85,6$ & 9 & $8,6-9$ & 9,5 & $0,9-1$ \\
\hline * etapa de retorno da concentração de OD para $2 \mathrm{mgO}_{2} / \mathrm{L}$ com descarte significativo do lodo.
\end{tabular}

$\mathrm{Na}$ Tabela 5.9, nas condições operacionais de 250 e $500 \mathrm{mg} \mathrm{N} / \mathrm{L}$, o primeiro número se refere a valores médios dos ciclos e o segundo número aos valores máximo das concentrações de nitrogênio inorgânico. Comparativamente, as velocidades específicas de remoção de nitrogênio nas condições operacionais de 250 e de $500 \mathrm{mg}$ N/L (via nitrito) são maiores que a condição operacional de $125 \mathrm{mg} \mathrm{N} / \mathrm{L}$ (com exceção da condição baixa de sólidos), da ordem de 30 e 20\%, respectivamente; indicando o efeito da concentração do nitrogênio na velocidade de remoção.

$\mathrm{Na}$ condição operacional de $125 \mathrm{mg} \mathrm{N} / \mathrm{L}$, a concentração de OD e a concentração de SSV influenciaram a velocidade de remoção de nitrogênio.

A velocidade de remoção de nitrogênio na condição operacional de $\mathrm{N}$-amoniacal afluente de $250 \mathrm{mg} \mathrm{N} / \mathrm{L}$ foi semelhante à velocidade na condição de $500 \mathrm{mg} \mathrm{N} / \mathrm{L}$. Neste caso, a diferença foi que na condição de $500 \mathrm{mg} \mathrm{N} / \mathrm{L}$, a duração de $2 \mathrm{~h}$ do período aeróbio não foi suficiente para nitrificar todo o $\mathrm{N}$-amoniacal adicionado.

$\mathrm{Na}$ condição operacional de $500 \mathrm{mg} \mathrm{N} / \mathrm{L}$, a escolha adequada da duração dos períodos aeróbios foi fundamental para se obter eficiência de remoção de nitrogênio via nitrito e, provavelmente, o longo tempo de operação também tenha colaborado para que houvesse adaptação a essa via.

Considerando-se que a biomassa em suspensão foi a mesma, sem reinoculação 
do reator, a velocidade de remoção nas condições estudadas foi claramente afetada pela concentração de $\mathrm{N}$-amoniacal, duração do período aeróbio, concentração de OD e concentração de SSV. Nesse último, devem ser consideradas as quantidades das populações nitrificantes e desnitrificantes e conseqüente adaptação dessas populações às condições ambientais no reator.

\section{6 - Ensaios adicionais}

\subsection{1 - Potencial de remoção de fósforo}

Foram efetuadas algumas análises de fósforo durante as condições operacionais e observou-se que a concentração de fósforo no efluente diminuiu, o que indicou que ocorreu remoção de fósforo (Figura 5.43).

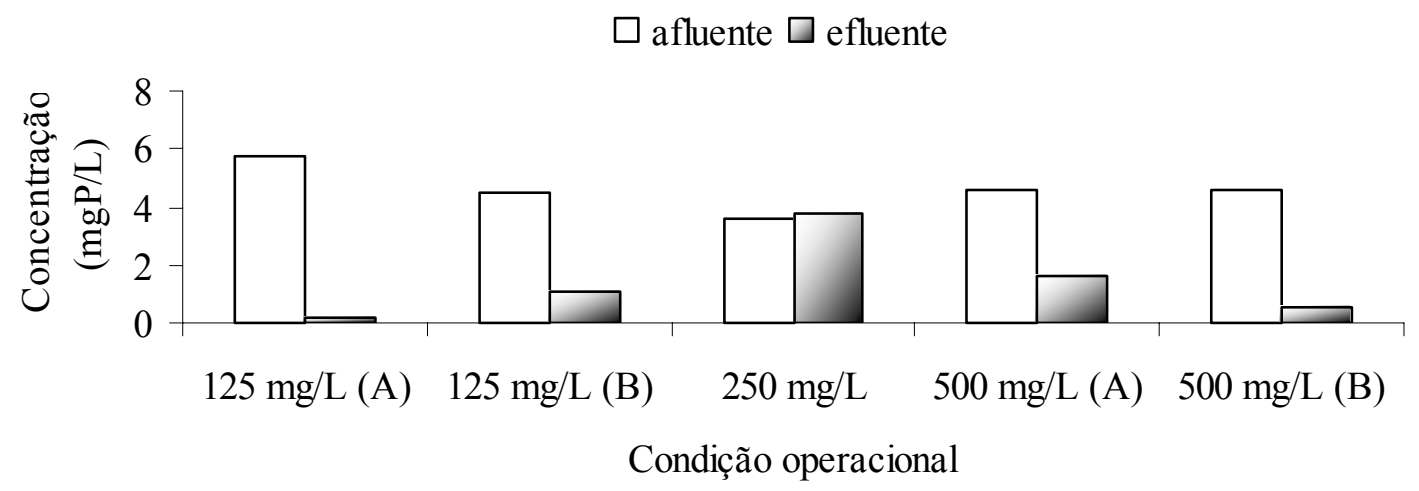

Figura 5.43 - Variação das concentrações de fósforo afluente e efluente durante o experimento.

Tipicamente, os sólidos biológicos contêm fósforo em percentual de 1,5 a 2\% do peso seco (SOUSA, 1996; JENKINS et al., 2003). Quando submetido a ciclos anaeróbio/aeróbio, ocorre a seleção de organismos capazes de absorver fósforo em níveis além da estequiometria requerida para o crescimento. O lodo de excesso desse tipo de sistema pode conter de 2,5 a 4 vezes mais fósforo do que o de sistema convencional. (SOUSA, 1996). 


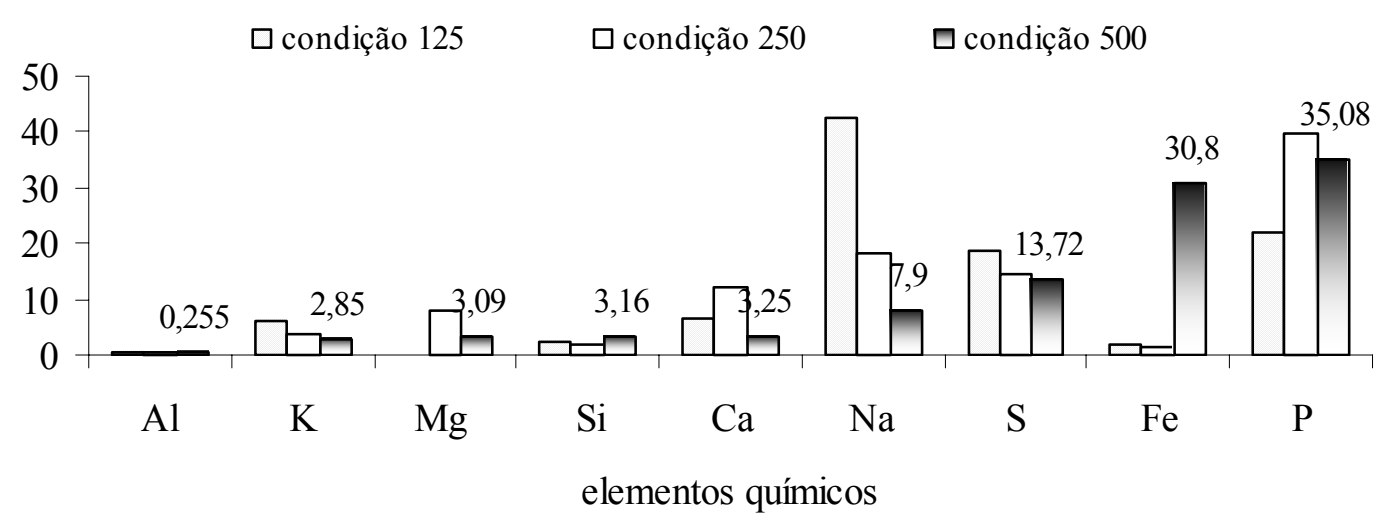

Figura 5.44 - Quantidade de elementos químicos (\%) encontrados nas microanálises quantitativas nas condições operacionais estudadas.

Os resultados obtidos com as microanálises (Figura 5.44) indicaram que havia $35,08 \%$ de fósforo no lodo. Considerando-se uma média de $5 \mathrm{mg} \mathrm{P} / \mathrm{L}$ que era adicionado diariamente no substrato e, multiplicando-se por 2 anos, chega-se à mesma quantidade de fósforo obtida na Figura 5.45. No caso, o cálculo foi efetuado considerando-se que a concentração média de SSV na condição operacional de $500 \mathrm{mg}$ $\mathrm{N} / \mathrm{L}$ foi de 9,5 g/L multiplicado pela \% de fósforo encontrado na amostra de lodo.

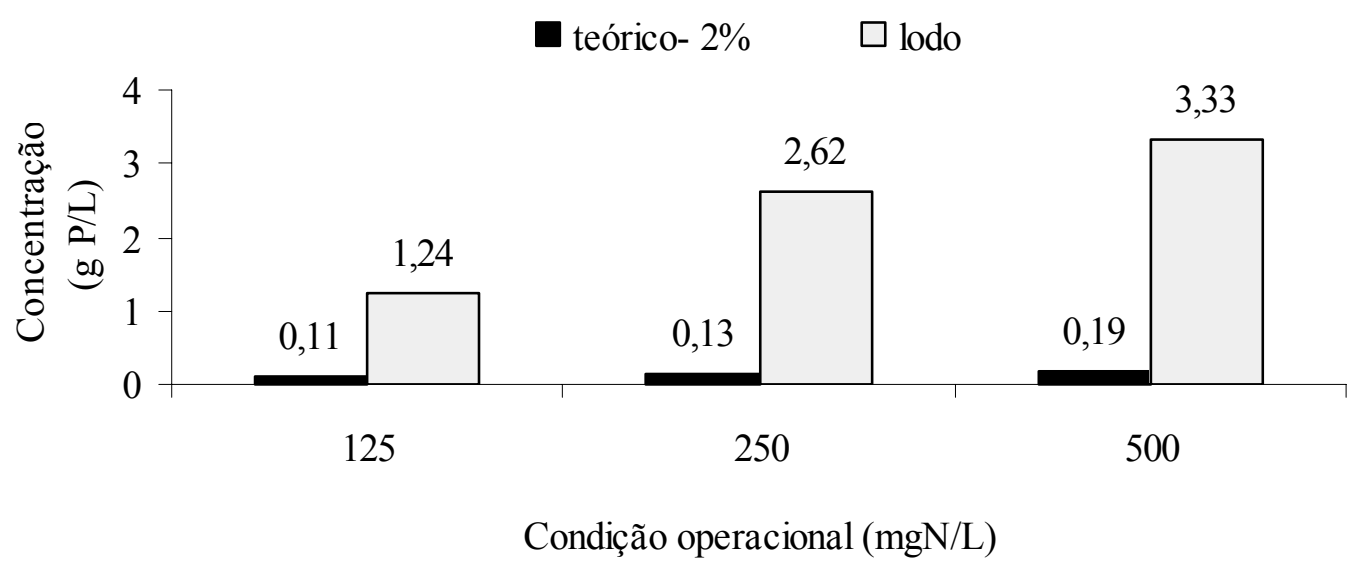

Figura 5.45 - Concentração de fósforo (mg P/L) ao final das condições operacionais, levando em consideração os resultados das microanálises.

Observa-se que houve acúmulo de fósforo durante a operação do reator, que também é evidenciado pela presença de bactérias semelhantes a bactérias acumuladoras de fósforo em todas as condições operacionais.

Os elementos químicos encontrados em maior porcentagem quantitativa por SOUSA (1996) foram: enxofre (2,91\%); silício (6,4\%); ferro $(11,63 \%)$; cálcio $(21,88 \%)$; fósforo $(52,14 \%)$. Esses resultados evidenciam, em termos percentuais, a presença acentuada de ferro, cálcio e fósforo que, teoricamente, poderiam ser 
precipitados de hidroxiapatita e fosfato férrico, segundo o autor. Ferro e enxofre foram encontrados em maior porcentagem, como apresentado na Figura 5.44, que também podem ter precipitado.

\subsection{2 - Uso alternativo de etanol para desnitrificação}

Realizou-se ensaio com uso de etanol ao invés de amido como fonte de carbono. O etanol foi misturado ao substrato e aplicado meia hora após o início do período anóxico para desnitrificação das formas oxidadas de nitrogênio. Esse ensaio foi efetuado após o final da condição operacional de $500 \mathrm{mgN} / \mathrm{L}$ com dois ciclos anóxicos/aeróbios

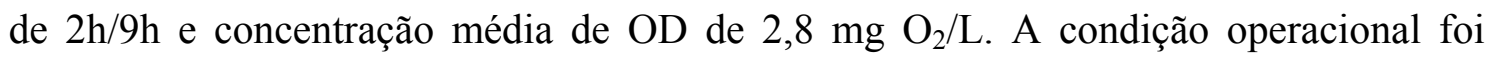
mantida com a substituição de etanol ao invés de amido na mistura do substrato.

Observou-se pela Figuras 5.46 e 5.47, que todo o nitrito e nitrato foram desnitrificados e nenhum $\mathrm{N}$-amoniacal foi consumido, como seria esperado no período anóxico. $\mathrm{O}$ etanol foi adicionado em excesso numa relação DQO/N maior que 3.

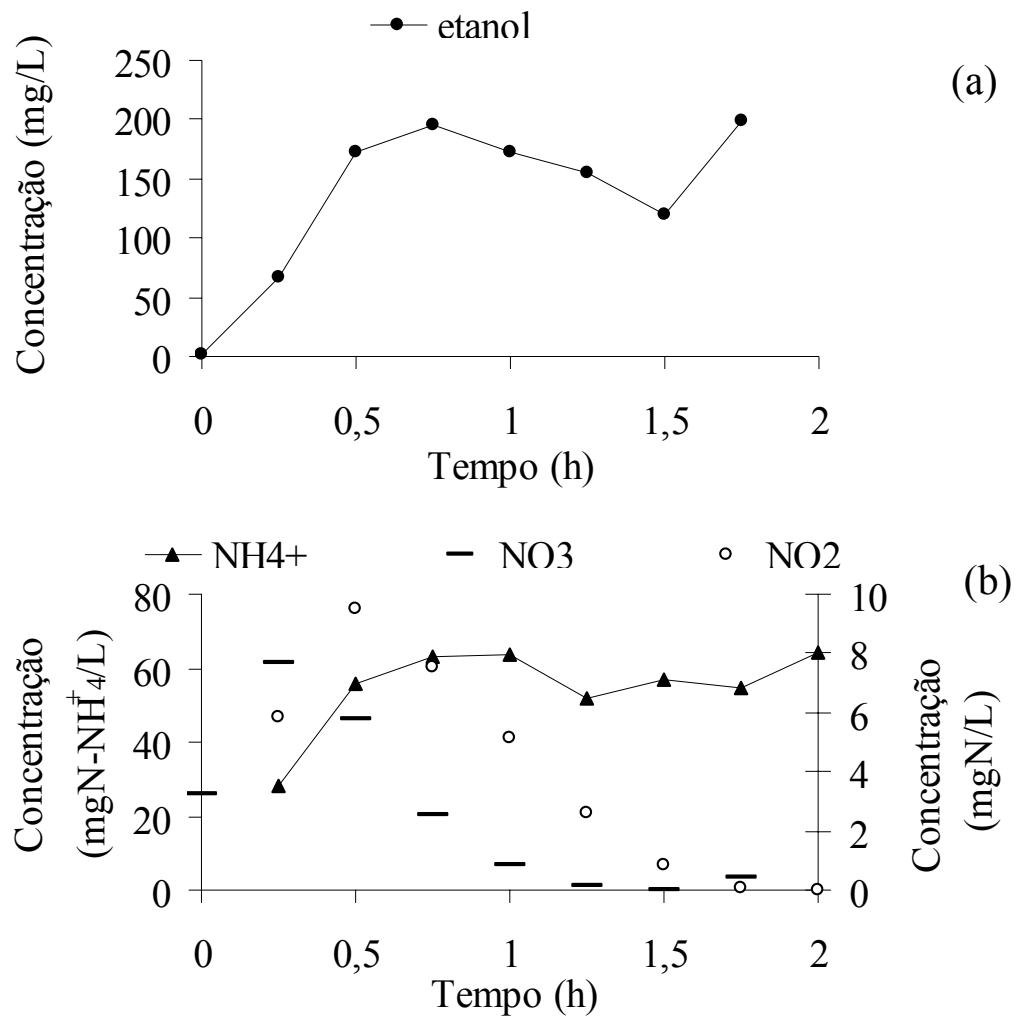

Figura 5.46 - Efeito da adição de etanol na variação temporal das concentrações de Namoniacal, nitrito, nitrato e etanol durante um período anóxico de $2 \mathrm{~h}$. Réplica 1.

(a) consumo de etanol e (b) consumo de nitrito e nitrato. 


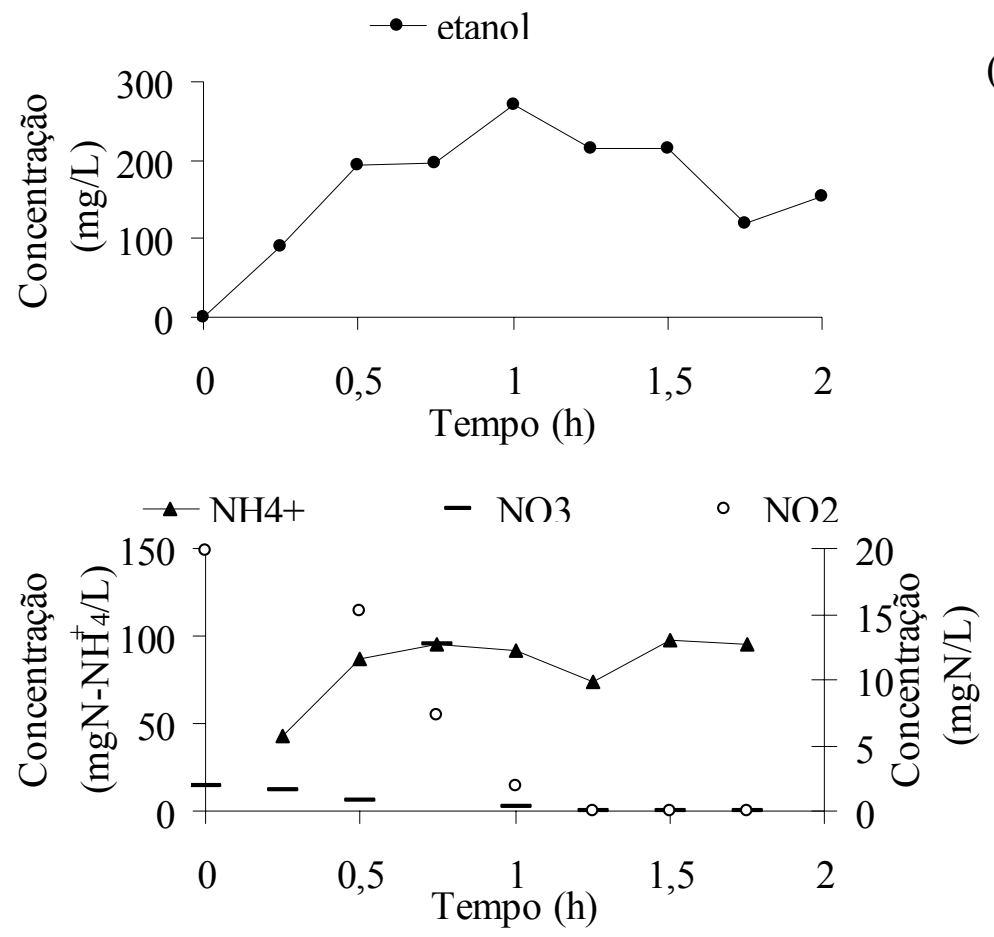

(a)

(b)

Figura 5.47 - Efeito da adição de etanol na variação temporal das concentrações de Namoniacal, nitrito, nitrato e etanol durante um período anóxico de $2 \mathrm{~h}$. Réplica 2.

(a) consumo de etanol e (b) consumo de nitrito e nitrato.

Observou-se que o tempo de desnitrificação diminuiu com a repetição da adição de etanol, com concentração de nitrito consideravelmente maior na segunda réplica (120 mg $\mathrm{N}^{-\mathrm{NO}_{2}} / \mathrm{L}$ ), mostrando a viabilidade de se utilizar etanol para desnitrificar.

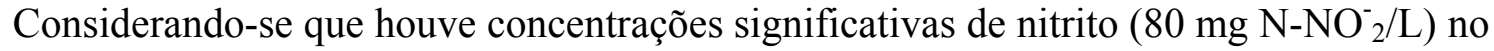
efluente da condição operacional de $500 \mathrm{mg} \mathrm{N} / \mathrm{L}$, o etanol poderia ser usado logo após o segundo ciclo anóxico/aeróbio de $2 \mathrm{~h} / 9 \mathrm{~h}$.

\section{7 - Exames microbiológicos}

Foram efetuados exames microbiológicos com o intuito de se estimar quantitativamente e qualitativamente as populações de organismos nitrificantes e desnitrificantes, bem como compará-las nas diferentes condições operacionais do estudo. Em todas as condições operacionais de N-amoniacal afluente (125, 250 e 500 $\mathrm{mg} \mathrm{N} / \mathrm{L}$ ), foram caracterizadas cepas bacterianas possivelmente vinculadas à remoção de nitrogênio no reator. 


\subsection{1 - Estimativa da microbiota nitrificante e desnitrificante}

As microbiotas nitrificante e desnitrificante foram estimadas no final de cada etapa operacional (Tabela 5.10). Com estes resultados, foi possível verificar qual a via mais favorável (via nitrito ou nitrato) para a remoção de nitrogênio nas três condições operacionais estudadas. Além disso, objetivou-se verificar a reação metabólica dos organismos quanto às alterações nas concentrações de $\mathrm{N}$-amoniacal afluente e da concentração de oxigênio dissolvido.

Como a produção celular das bactérias oxidantes de $\mathrm{N}$-amoniacal é maior que a das bactérias oxidantes de nitrito, em sistemas nitrificantes convencionais, as bactérias oxidantes de $\mathrm{N}$-amoniacal devem estar presentes em maior número que o das oxidantes de nitrito (BARNES e BLISS, 1983).

Teoricamente, com o aumento da concentração de $\mathrm{N}$-amoniacal e conseqüentemente das concentrações de amônia livre, a tendência das populações oxidantes de nitrito seria o de diminuição (KUAI e VERSTRAETE, 1998; YUN e KIM, 2003), o que aconteceu efetivamente, conforme pode ser observado na Tabela 5.10, numa proporção de $99,95 \%$ de redução na população. Torna-se evidente que as bactérias oxidantes de nitrito apresentam maior sensibilidade às elevadas concentrações de N-amoniacal.

Segundo Kuai e Verstraete (1998), o lodo convencional (que não acumula nitrito) contém a mesma quantidade de bactérias oxidantes de $\mathrm{N}$-amoniacal e de nitrito $\left(3,5 \times 10^{11}\right.$ e $1,4 \times 10^{11} / \mathrm{g} \mathrm{SSV}$, respectivamente). Após enriquecimento do lodo sob

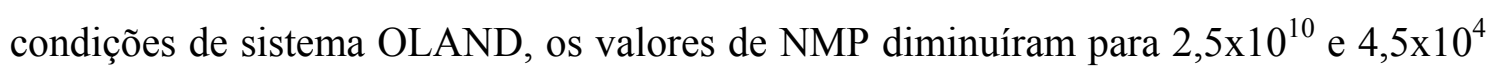
/g SSV para bactérias oxidantes de N-amoniacal e de nitrito, respectivamente. Segundo os autores, o número de bactérias oxidantes de nitrito apresentou redução drástica devido à limitação de oxigênio por longo tempo. Houve decréscimo na ordem de grandeza de 6 no NMP de organismos oxidantes de nitrito, enquanto que, neste experimento, a ordem de grandeza foi de 3 .

No caso de sistemas de biofilme, Yun e Kim (2003) obtiveram valores de NMP

de $4,7 \times 10^{5} / \mathrm{mL}$ e $3,8 \times 10^{4} / \mathrm{mL}$, para bactérias oxidantes de $\mathrm{N}$-amoniacal e de nitrito, respectivamente, em condições operacionais de concentração de $500 \mathrm{mg} \mathrm{N}-\mathrm{NH}^{+}{ }_{4} / \mathrm{L}$ e concentração média de OD de $6 \mathrm{mg} \mathrm{O}_{2} / \mathrm{L}$. Os autores consideraram que o efeito de arraste é muito maior em reatores em suspensão do que em reatores de biofilme, o que 
explica a proporção relativamente maior de bactérias oxidantes no reator de biofilme quando comparado ao sistema OLAND. O efeito de arraste em reatores de biofilme é reduzido, pois as bactérias oxidantes de nitrito apresentam tendência a formarem agregados no biofilme nitrificante.

$\mathrm{Na}$ condição operacional com concentração afluente de $125 \mathrm{mg} \mathrm{N} / \mathrm{L}$, que resultou em nitrificação convencional via nitrato, as bactérias oxidantes de nitrito se encontraram em maior número que as bactérias oxidantes de $\mathrm{N}$-amoniacal (Tabela 5.10 e Figura 5.48) Adicionalmente, o número de organismos desnitrificantes apresentou a mesma ordem de grandeza dos organismos nitrificantes (Tabela 5.10). Porém, a via nitrato ainda apresenta uma população maior do que a via nitrito.

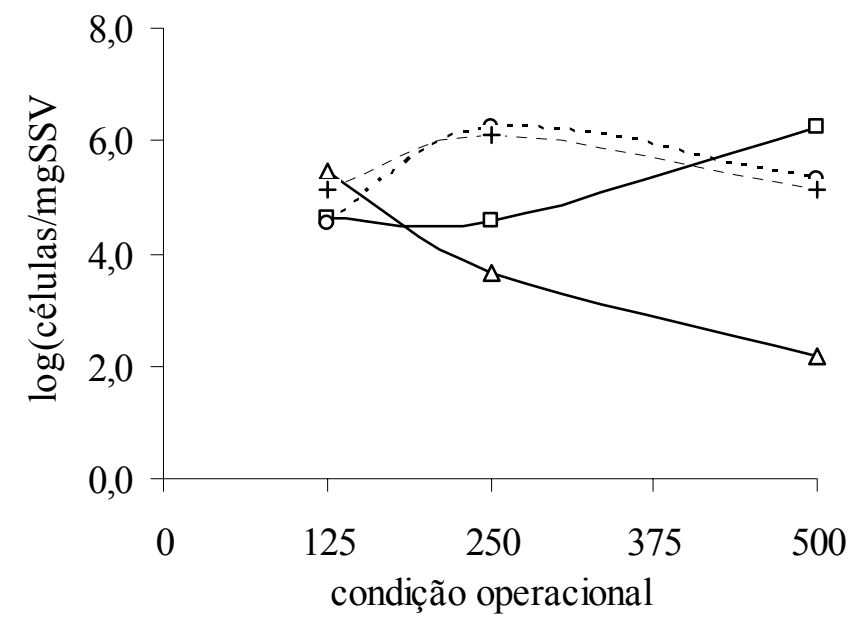

Figura 5.48 - Log da razão NMP das células e concentração de SSV nas condições operacionais descritas na Tabela 5.10.( $\square$ ) organismos oxidantes de N-amoniacal; $(\Delta)$ organismos oxidantes de nitrito; $(\circ)$ desnitrificantes via nitrito; $(+)$ desnitrificantes via nitrato.

A condição $2(250 \mathrm{mg} \mathrm{N} / \mathrm{L})$ evidencia a redução nas populações nitrificantes oxidantes de nitrito, enquanto as oxidantes de $\mathrm{N}$-amoniacal, permanecem na mesma ordem de grandeza; e aumento na população desnitrificante, tanto na via nitrito quanto na via nitrato.

A condição 3 (500 mg N/L) apresentou o menor valor para a razão entre NMP de células e concentração de sólidos voláteis para organismos oxidantes de nitrito. Aparentemente a alta concentração de $\mathrm{N}$-amoniacal foi prejudicial ao crescimento desses organismos, que demonstraram maior sensibilidade à elevada concentração de Namoniacal comparada com os organismos oxidantes de $\mathrm{N}$-amoniacal e desnitrificantes. 
Tabela 5.10 - Número Mais Provável de organismos nitrificantes nas condições operacionais estudadas.

\begin{tabular}{|c|c|c|c|c|c|c|c|c|c|c|}
\hline & & & & & & & \multicolumn{4}{|c|}{ Desnitrificantes } \\
\hline \multicolumn{3}{|c|}{ N-amoniacal } & \multicolumn{2}{|c|}{$\begin{array}{c}\text { Oxidantes de N- } \\
\text { amoniacal }\end{array}$} & \multicolumn{2}{|c|}{$\begin{array}{c}\text { Oxidantes de } \\
\text { nitrito }\end{array}$} & \multicolumn{2}{|c|}{ Via nitrito } & \multicolumn{2}{|c|}{ Via nitrato } \\
\hline $\begin{array}{c}\text { Condição } \\
\text { operacional }\end{array}$ & $\begin{array}{l}\text { afluente } \\
(\mathrm{mgN} / \mathrm{L})\end{array}$ & $\begin{array}{c}\mathrm{OD} \\
\left.\mathrm{mgO}_{2} / \mathrm{L}\right)\end{array}$ & $\begin{array}{c}\text { (NMP/ } \\
\text { mgSSV) }\end{array}$ & $\begin{array}{c}\text { (NMP/ } \\
\mathrm{mL})\end{array}$ & $\begin{array}{c}\text { (NMP/ } \\
\text { mg SSV) }\end{array}$ & $\begin{array}{c}\text { (NMP/ } \\
\mathrm{mL})\end{array}$ & $\begin{array}{c}\text { (NMP/ } \\
\text { mg SSV) }\end{array}$ & $\begin{array}{c}\text { (NMP/ } \\
\mathrm{mL})\end{array}$ & $\begin{array}{c}\text { (NMP/ } \\
\text { mg SSV) }\end{array}$ & $\begin{array}{c}\text { (NMP/ } \\
\mathrm{mL})\end{array}$ \\
\hline 1 & 125 & 2 a 2,5 & $4,4 \times 10^{4}$ & $5,4 \times 10^{4}$ & $3,0 \times 10^{5}$ & $1,8 \times 10^{6}$ & $3,4 \times 10^{4}$ & $1,9 \times 10^{5}$ & $1,4 \times 10^{5}$ & $7,9 \times 10^{5}$ \\
\hline 2 & 250 & 2 a 2,5 & $3,7 \times 10^{4}$ & $1,1 \times 10^{5}$ & $4,4 \times 10^{3}$ & $1,3 \times 10^{4}$ & $1,8 \times 10^{6}$ & $5,4 \times 10^{6}$ & $1,3 \times 10^{6}$ & $3,9 \times 10^{6}$ \\
\hline 3 & 500 & 2,5 a 3 & $1,7 \times 10^{6}$ & $1,4 \times 10^{7}$ & $1,5 \times 10^{2}$ & $1,3 \times 10^{3}$ & $2,1 \times 10^{6}$ & $1,7 \times 10^{6}$ & $1,3 \times 10^{5}$ & $1,1 \times 10^{6}$ \\
\hline
\end{tabular}


Ao final do experimento, os organismos desnitrificantes apresentaram NMP com a mesma ordem de grandeza inicial com a condição 1 (125 mg N/L - Tabela 5.10).

Callado e Foresti (2001) obtiveram que o NMP de microrganismos desnitrificantes diminuiu do início $\left(2,5 \times 10^{6} / \mathrm{mL}\right)$ para o final $\left(3,5 \times 10^{5} / \mathrm{mL}\right)$ da operação, porém esse decréscimo não afetou o processo de desnitrificação.

As bactérias desnitrificantes via nitrito e via nitrato apresentaram a mesma ordem de grandeza tanto na condição 2 como na condição 3 , evidenciando a possibilidade de ocorrência das duas vias. No entanto, como a população de oxidantes de nitrito sofreu redução de 99,95\%, provavelmente a via favorecida para desnitrificação seria a desnitrificação via nitrito, o que ocorreu principalmente na condição operacional de $500 \mathrm{mg} \mathrm{N} / \mathrm{L}$.

\subsection{2 - Isolamento e seqüenciamento do DNA 16S de cepas bacterianas das amostras retiradas durante a operação com concentração de $\mathbf{N}$-amoniacal afluente de 125, 250 e $500 \mathrm{mg} \mathrm{N} / \mathrm{L}$.}

As seqüências de nucleotídeos relativas a $540 \mathrm{pb}$ obtidas para as concentrações de 125 e $250 \mathrm{mg} \mathrm{N} / \mathrm{L}$ foram similares:

TAACCTTGCGGCCGTACTCCCCAGGCGGTCGACTTCACGCGTTAGCTGCGTCACTCAGTGCA TTGCTGCTCCGAACGACTAAGTCGACATCGTTTAGGGGCGTGGGACTAACCAGGGTATCTAA ATCCTGTTTGCTCCCCACGCTTTCGTGCATGAGCGTCAGTACAGGCCCAGGGGGCTGCCTTC GCCATCGGTGTTCCTCCTGATATCTACGCATTTCACTGCTACACCAGGAATTCCACCCCCCTC TGCCGTACTCTAGCCTTGCAGTCACAAACGCAGTTCCCAGGTTAAGCCCGGGGATTTCACAT CTGTCTTACAAAACCGCCTGCGCACGCTTTACGCCCAGTAATTCCGATYAACGCTCGCACCC TACGTATAACCGCGGCTGCTGGCACGTAGTTAGCCGGTGCTTCTTAGTCGGTACGTCATCCA CGCACTATGTTAGAGTGCGCGATTTCTTCCCGGCCGAAAGAGCTTACAACCCGAAGGGCTTC TTCATCACGCGGCATGGCTGGGATCAGGGTTGGCCCCATCGTC.

A seqüência alinhada através do programa DNASTAR-Package Software (Lasergene Sequence Analysis) foi comparada às seqüências de nucleotídeos do banco de dados eletrônico NCBI-database para a aproximação da identidade filogenética. Tal alinhamento mostrou similaridade de 97\% para Thauera mechernichensis e Thauera sp. 27, com números de identificação no NCBI-Blast de Y17590 e AY838760, respectivamente. As imagens da cepa isolada e com coloração Gram podem ser vistas nas Figuras 5.49a 5.49b. As imagens da bactéria isolada observada em microscopia de 
contraste de fase e de luz comum para visualização das colorações de Neisser e de PHA, respectivamente (aumento de 1500X) podem ser vistas nas Figuras 5.49c e 5.49d.

Os resultados da condição operacional de $125 \mathrm{mgN} / \mathrm{L}$ são referentes à bactérias desnitrificantes com nitrato como aceptor de elétrons, considerando-se que o nitrato foi o produto da nitrificação durante essa condição. Na condição operacional de $250 \mathrm{mg}$ N/L, os resultados são referentes a nitrato como aceptor de elétrons, pois houve dificuldades no isolamento das bactérias desnitrificantes via nitrito.

Etchebehere et al. (2002) isolaram entre os microrganismos desnitrificantes do reator UASB: as bactérias Thauera mechernichensis e T. linaloolentis, que realizam desnitrificação eficiente.

Castro Daniel (2005) obteve os mesmos microrganismos na amostra de DNA total na concentração de $250 \mathrm{mg} \mathrm{N} / \mathrm{L}$ com o mesmo índice de similaridade, em experimento com RBS com leito fixo.
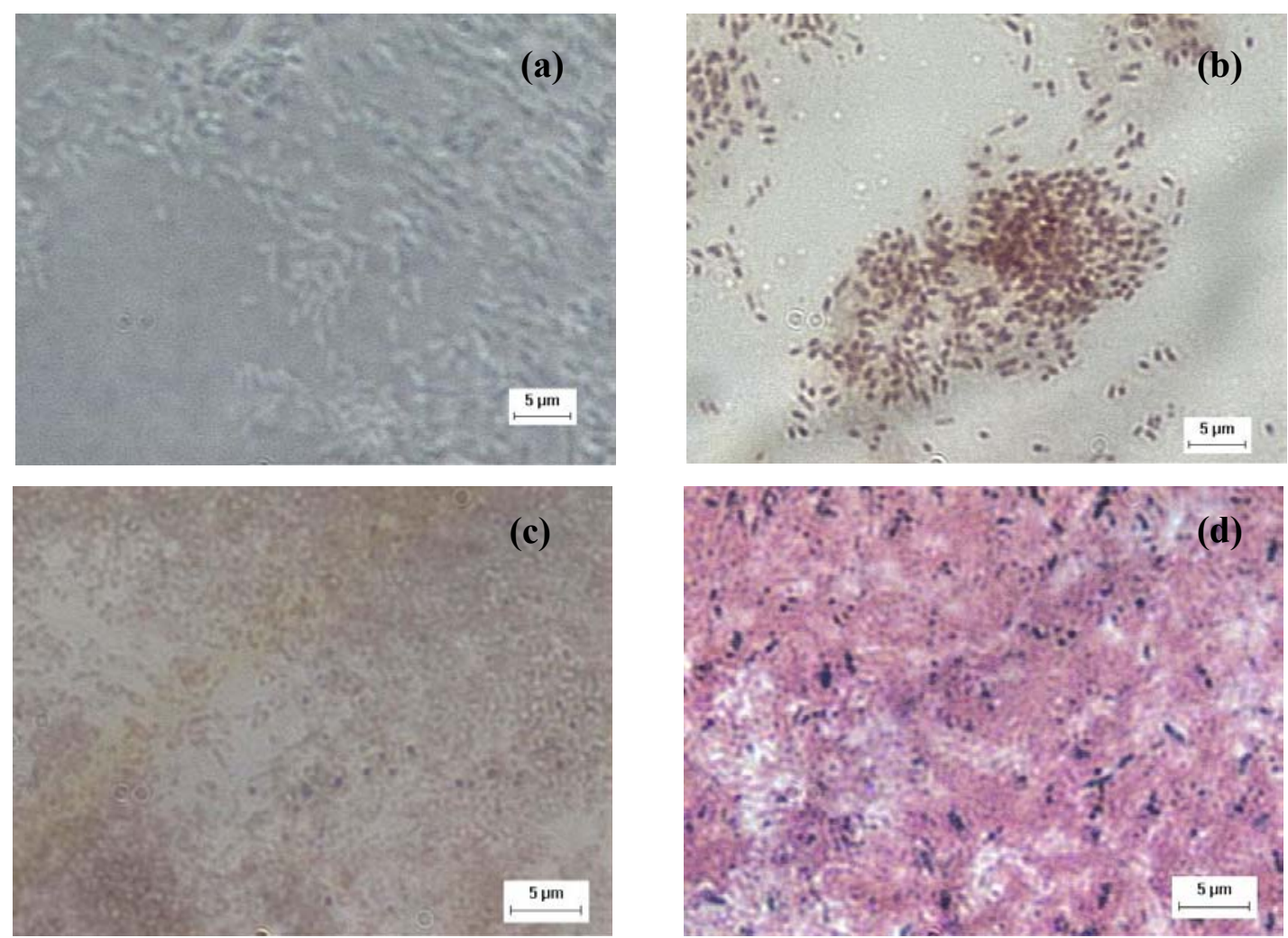

Figura 5.49 - Microfotografias da cepa isolada nas condições operacionais de 125 e $250 \mathrm{mg} \mathrm{N}$ /L: (a) cepa isolada, em contraste de fase; (b) bactérias Gram negativas; (c) coloração de Neisser (positivo); coloração de PHA (positivo).

A seqüência de nucleotídeos do DNAr 16S, relativa a 548 pb, obtida para a concentração de $500 \mathrm{mg} \mathrm{N} / \mathrm{L}$ encontra-se descrita a seguir: 
AAACTCCCCAACGGCTAACATTCATCGTTTACGGCGTGGACTACCAGGGTATCTAATCCTGT TTGCTCCCCACGCTTTCGCACCTCAGCGTCAGTAATGGTCCAGTGAGCCGCCTTCGCCACTGG TGTTCCTCCGAATATCTACGAATTTCACCTCTACACTCGGAATTCCACTCACCTCTACCATAC TCAAGACTTCCAGTATCAAAGGCAGTTCCGGGGTTGAGCCCCGGGATTTCACCCCTGACTTA AAAGTCCGCCTACGTGCGCTTTACGCCCAGTAAATCCGAACAACGCTAGCCCCCTTCGTATT ACCGCGGCTGCTGGCACGAAGTTAGCCGGGGCTTCTTCTCCGGTTACCGTCATTATCTTCACC GGTGAAAGAGCTTACAACCCTAGGGCCTTCATCACTCACGCGGCATGGCTGGATCAGGCTTG CGCCCATTGTCCAATATTCCCCACTGGCTGCCTCCGTAAGGAGTCTGGG

A seqüência alinhada através do programa DNASTAR-Package Software (Lasergene Sequence Analysis) foi comparada às seqüências de nucleotídeos do banco de dados eletrônico NCBI-database para a aproximação da identidade filogenética. Tal alinhamento mostrou similaridade de $99 \%$ para Ochrobactrum anthropi e Ochrobactrum tritici, com números de identificação no NCBI-Blast de AY772689 e AF508092, respectivamente.

A cepa isolada pode ser observada na Figura 5.50a, representada por bacilos isolados com extremidades arredondadas apresentando coloração Gram-negativa. A cepa obtida foi isolada tanto para condição de nitrato como nitrito como aceptor de elétrons. O resultado da coloração de Neisser foi negativo, portanto não indicando granulação de polifosfato (Figura 5.50).

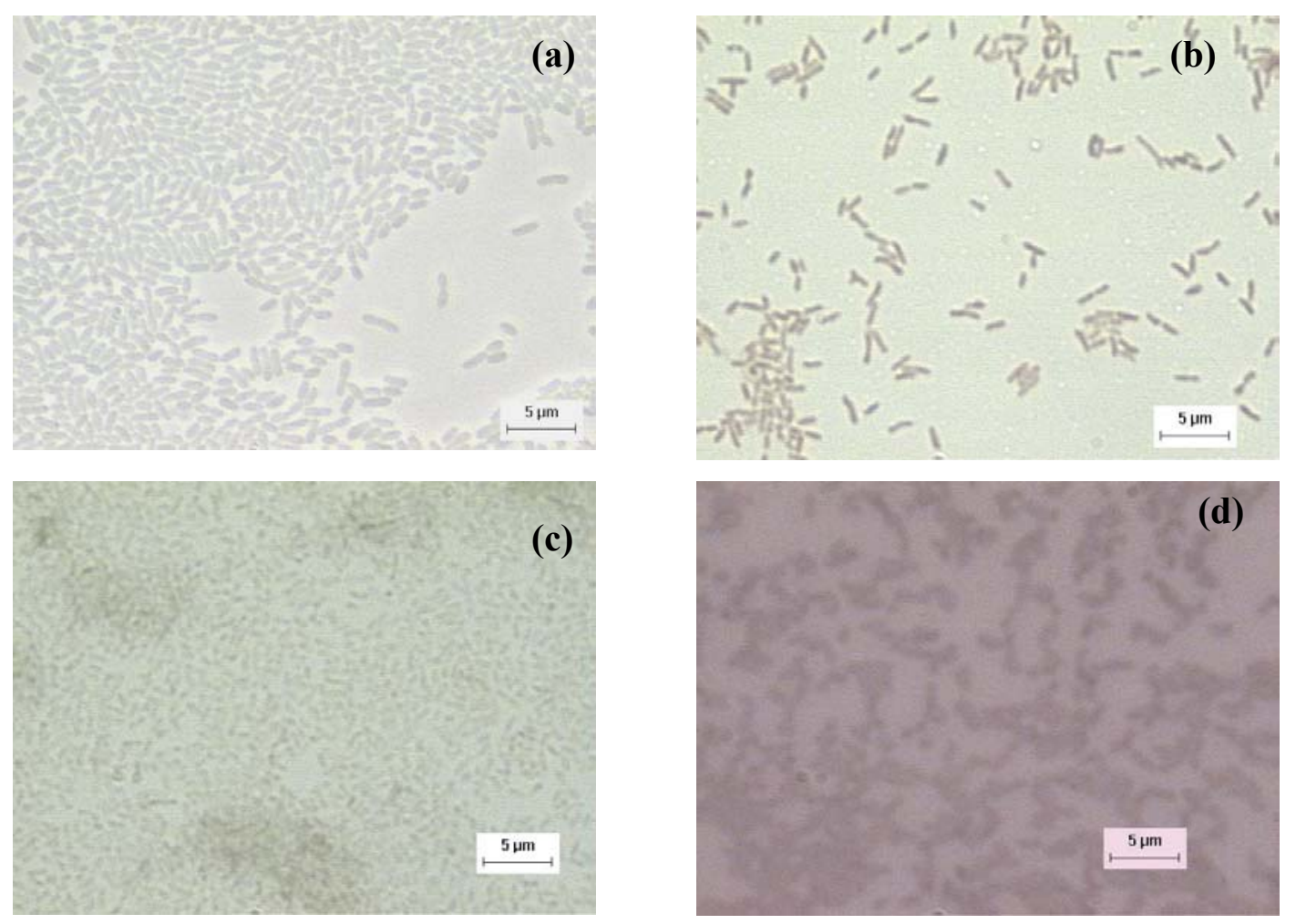

Figura 5.50 - Microfotografias da cepa isolada na condição operacional de $500 \mathrm{mg} \mathrm{N} / \mathrm{L}$ : (a) cepa isolada, em contraste de fase; (b) bactérias Gram negativas; (c) coloração de Neisser (negativo); coloração de Neisser (negativo). 
Espécies de Ochrobactrum eficientes na desnitrificação foram isoladas e caracterizadas por métodos de Biologia Molecular em reator seqüencial em batelada com alternância de ciclos anaeróbio e aeróbio. Também foi revelado que a espécie Ochrobactrum anthropi é capaz de desnitrificar e acumular fosfato simultaneamente (MERZOUKI et al., 1998).

Bactérias redutoras de nitrato da espécie Ochrobactrum tritici, isoladas de ambientes naturais e contaminados, em baixas concentrações de oxigênio, com meios contendo nitrato, mostraram-se capazes de degradar fenol como única fonte de carbono e de energia (BAEK et al., 2003). 


\section{6 - CONCLUSÕES}

A adoção da estratégia de operação de reator em batelada seqüencial com vários ciclos alternados anóxico/aeróbio apresentou diferentes resultados nas concentrações de 125,250 e $500 \mathrm{mg} \mathrm{N} / \mathrm{L}$. A aeração intermitente e alimentação batelada possibilitaram a estabilidade do pH, com controle da inibição por amônia livre. As eficiências de remoção de nitrogênio foram semelhantes, ao redor de $80 \%$. Em concentração de Namoniacal de $125 \mathrm{mg} \mathrm{N} / \mathrm{L}$, o nitrato foi o produto final da nitrificação, enquanto que, para a concentração de $\mathrm{N}$-amoniacal de $250 \mathrm{mg} \mathrm{N} / \mathrm{L}$, obteve-se predominância de nitrito na nitrificação, com ocorrência de nitrificação e desnitrificação simultâneas nos dois primeiros ciclos. No primeiro ciclo anóxico após cada sedimentação e descarte, a concentração de amônia livre inicial no reator, a concentração de oxigênio dissolvido afetaram o consumo do íon amônio e a produção de nitrito e nitrato nos dois primeiros ciclos anóxico/ aeróbio em concentração de $\mathrm{N}$-amoniacal de $250 \mathrm{mg} \mathrm{N} / \mathrm{L}$, condicionando a predominância de nitrito no reator.

$\mathrm{Na}$ condição de $\mathrm{N}$-amoniacal de $500 \mathrm{mg} \mathrm{N} / \mathrm{L}$, a estratégia de alimentação batelada não impediu a aparente inibição da nitrificação pela presença de amônia livre. Após 309 dias e após o aumento da duração do período aeróbio obtiveram-se as maiores eficiências de remoção de nitrogênio (94\%).

O potencial redox pode ser usado como parâmetro de controle para determinação da duração dos períodos anóxicos e aeróbios:

- Para a concentração amoniacal afluente de $125 \mathrm{mg} \mathrm{N} / \mathrm{L}$ e concentração média de OD de $2 \mathrm{mg} \mathrm{O}_{2} / \mathrm{L}$, o ciclo anóxico/aeróbio de 1,5h/1,5h seria suficiente para a remoção de nitrogênio, enquanto que, para concentração média de OD de 1,5 mg $\mathrm{O}_{2} / \mathrm{L}$, uma duração do período aeróbio menor que $1,5 \mathrm{~h}$ seria suficiente.

- Esse mesmo ensaio indicou que duração de 1hora para os períodos anóxicos e aeróbios, indicado pela constância de potencial redox após total oxidação de Namoniacal e redução de Nox, seria suficiente para nitrificar e desnitrificar em 
concentração amoniacal afluente de $250 \mathrm{mg} \mathrm{N} / \mathrm{L}$.

○ Em condição operacional de $500 \mathrm{mg} \mathrm{N} / \mathrm{L}$, o parâmetro dPOR/dt (variação do potencial redox no tempo) não foi muito preciso (variação muito grande) como parâmetro de monitoramento do processo, pois apenas o dPOR foi suficiente para achar os pontos de início e término dos períodos aeróbios. Nessa concentração, a adoção de ciclos anóxicos/aeróbios de $1 \mathrm{~h} / 8 \mathrm{~h}$ seria suficiente para a remoção de nitrogênio via nitrito.

Os ensaios microbiológicos forneceram resultados muito interessantes como ensaios complementares.

- Nas análises microscópicas foram visualizados dois efeitos principais:

○ Aumento aparente da população de bactérias filamentosas durante período de baixa concentração de OD e baixa concentração de P.

○ Presença de bactérias semelhantes às acumuladoras de fósforo em todas as condições operacionais.

- Diminuição da população de nitrificantes oxidantes de nitrito devido às condições operacionais adotadas (presença de amônia livre, baixa concentração de OD). Essa diminuição e a adaptação das bactérias desnitrificantes resultou em progressiva remoção de nitrogênio via nitrito.

- As cepas isoladas para as condições operacionais de 125 e $250 \mathrm{mg} \mathrm{N} / \mathrm{L}$, tanto para a desnitrificação via nitrito como para a via nitrato foram similares a Thauera mechernichensis e Thauera sp 27, com similaridade de 97\%. Enquanto que na concentração de $500 \mathrm{mgN} / \mathrm{L}$ foi Ochrobactrum anthropi e Ochrobactrum tritici.

Os resultados evidenciam que é possível a remoção de nitrogênio em águas residuárias com alta concentração de $\mathrm{N}$-amoniacal (até $500 \mathrm{mg} \mathrm{N} / \mathrm{L}$ ) com relativa concentração de OD (até 2,8 $\mathrm{mg} \quad \mathrm{O}_{2} / \mathrm{L}$ ) operando-se com ciclos alternados anóxicos/aeróbios, porém após longo período de adaptação. 


\section{7 - SUGESTÕES}

Como sugestões para trabalhos futuros, propõe- se investigar:

○ Aplicar com concentração de $500 \mathrm{mg} \mathrm{N} / \mathrm{L}$ com ciclo anóxico/aeróbio de $1 \mathrm{~h} / 8 \mathrm{~h}$ com

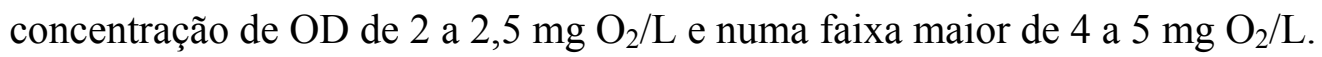

- Operar o reator com menor quantidade de lodo biológico.

- Para substratos com concentrações muito elevadas de nitrogênio amoniacal e baixa concentração de matéria orgânica, usar etanol como fonte de carbono no último período anóxico, após todo o afluente ter sido adicionado nas etapas anteriores, para possibilitar a desnitrificação sem a adição de nitrogênio amoniacal.

○ Após a adaptação do lodo à remoção de nitrogênio via nitrito, com concentrações elevadas de nitrogênio, submeter o reator a concentrações baixas, da ordem de 40 mg N/L, para verificar se a desnitrificação via nitrito se mantém.

- Acompanhar potencial redox nessas alterações das condições operacionais, para observar se apresenta mesma tendência obtida nesse experimento. 


\section{8 - REFERÊNCIAS}

ABELING, U.; SEYFRIED, C.F. (1992). Anaerobic-aerobic treatment of high-strength ammonium wastewater. Nitrogen removal via nitrite. Water Science Technology, Oxford, v.26, n.5-6, p.1007-15.

AESOY, A.; ODEGAARD, H; BACH, K.; PUJOL, R.; HAMON, M. (1998). Denitrification in a packed bed biofilm reactor (BIOFOR) - Experiments with carbon source. Water Research, New York, v. 32, n.5, p.1463-70.

AHN, J.; DAIDOU, T.; TSUNEDA, S.; HIRATA, A. (2002). Characterization of denitrifying phosphate accumulating organisms cultivated under different electron aceptor conditions using polymerase chain reaction-denaturing gradient gel electrophoresis assay. Water Research, New York, v.36, p. 403-12.

ALEXANDER, M. (1982). Most probable number method for microbial populations. In: PAGE, A.L.; MILLER, R.H.; KEENEY, D.R. Methods of soil analysis. Winsconsin: American Society of Agronomy. Cap. 39, 815-20.

ALLEMAN, J.E. (1985). Elevated nitrite occurrence in biological wastewater treatment systems. Water Science Technology, Oxford, v.17, p.409-19.

ALLEMAN, J.E., IRVINE, R.L. (1980). Storage-induced denitrification using sequencing batch reactor operation. Water Research, New York, v.14, p.1483-8.

ALMEIDA, J.S.; JULIO, S.M.; REIS, M.A.M.; CARRONDO, M.J.T. (1995). Nitrite inhibition of denitrification by Pseudomonas fluorescens. Biotechnology Bioengineering, New York, v. 46, p.194-201.

ANTHONISEN, A.C.; LOEHR, R.C.; PRAKASAM, T.B.S.; SRINATH, E.G. (1976). Inhibition of nitrification by ammonia and nitrous acid. Journal Water Pollution Control Federal, Alexandria, v.48, n.5, p.835-52. 
APHA, AWWA, WPCF. (2000). Standard methods for the examination of water and wastewater. 20 th. Edition. Washington. 1 CD-ROM.

ARORA, M.L.; BARTH, E.F.; UMPHRES, M.B. (1985). Technology evaluation of sequencing batch reactors. Journal Water Pollution Control Federal, Alexandria, v.57, n.8, p.867-75.

ATLAS, R.M.; BARTHA, R. (1987). Microbial ecology - Fundamentals and Applications. $2^{\text {nd }}$ ed. California: The Benjamin Cummings Publishing Company, Inc.

BAE, W.; BAEK, S.; CHUNG, J.; LEE, Y. (2002). Optimal operational factors for nitrite accumulation in batch reactors. Biodegradation, Dordrecht, v.12, p.359-66.

BAEK, S.H.; KIM, K.H.; YIN, C.R.; JEON, C.O.; IM, W.T.; KIM, K.K.; LEE, S.T. (2003). Isolation and characterization of bacteria capable of degrading phenol and reducing nitrate under low-oxygen conditions. Current Microbiology, New York, v. 47, n.6, p.462-66.

BARNES, D.; BLISS, P.J. (1983). Biological control of nitrogen in wastewater treatment. New York: E\&F Spon.

BERNET, N.; DELGENES, N.; AKUNNA, J.C.; DELGENES, J.P.; MOLETTA, R. (2000). Combined anaerobic aerobic SBR for the treament of piggery wastewater. Water Research, New York, v.34, n.2, p.611-9.

BOCK, E.; KOOPS, H.P.; AHLERS, B.; HARMS, H. (1991). Oxidation of inorganic nitrogen compounds as energy source. In: BALLOWS, A.; TRUPER, H.G.;DWORKIN, M.; HARDER, M.; SCHLEIFER, K.H. The prokaryotes. New York: Springer Verlag. Cap.17, p.414-30.

BORTONE, G.; GEMELLI, S.; RAMBALDI, A.; TILCHE, A. (1992). Nitrification, denitrification and biological phosphate removal in sequencing batch reactors treating piggery wastewater. Water Science Tecnology, Oxford, v.26, n.5-6, p.977-85.

BRASIL. Fundação Nacional de Saúde. (2001). Portaria $n^{\circ} 1.469 / 2000$, de 29 de outubro de 2000, Controle e vigilância da qualidade da água para consumo humano e seu padrão de potabilidade. Brasília, Fundação Nacional de Saúde, 2001. 32p.

BRASIL (2005). Resolução $\mathrm{n}^{\circ} 357$, de 17 de março de 2005. Dispões sobr a classificação dos corpos de água e diretrizes ambientais para o seu enquadramento, bem 
como estabelece as condições e padrões de lançamento de efluentes e dá outras providências. Diário Oficial [da] República Federativa do Brasil, Poder Legislativo, Brasilia, DF, 18 de março. Seção 1, p.58.

CALLADO SARMENTO, N.H. (2001). Reatores sequenciais em batelada em sistema anaeróbio/aeróbio tratando esgoto sanitário sintético e com remoção de nutrientes. 227p. Tese (Doutorado) - Escola de Engenharia de São Carlos, Universidade de São Paulo, São Carlos. 2001.

CALLADO, N.H.; FORESTI, E. (2001). Removal of organic carbon, nitrogen and phosphorus in sequential batch reactors integrating the aerobic/anaerobic processes. Water Science Tecnology, Oxford, v.44, n.4, p.263-70

CARRERA, J.; VICENT, T.; LAFUENTE, J. (2004). Effect of influent COD/N ratio on biological nitrogen removal (BNR) from high strength ammonium industrial wastewater. Process Biochemistry, London, v.39, n.12, p.2035-41.

CASTRO DANIEL, L.M. (2005). Remoção de nitrogênio via nitrito em reator operado em bateladas seqüenciais contendo biomassa imobilizada e aeração intermitente. 106p. Tese (Doutorado) - Escola de Engenharia de São Carlos, Universidade de São Paulo, São Carlos. 2005.

ÇECEN, F.; GÖNENÇ, I.E. (1995). Criteria for nitrification and denitrification of high strength wastes in two upflow submerged filters. Water Environment Research, Alexandria, v.67, n.2, p.132-42, 1995.

ÇEÇEN, F. (1996). Investigation of partial and full nitrification characteristics of fertilizer wastewaters in a submerged biofilm reactor. Water Science Technology, Oxford, v.34, n.11, p.77-85.

CHERNICHARO, C.A. (Org.) (2001). Pós tratamento de efluentes de reatores anaeróbios. Belo Horizonte: [s.n.]. Projeto PROSAB.

CHEN, K.C.; CHEN, J.J.; YOUNG, J.U. (2000). Improvement of nitrogen-removal efficiency using immobilized microorganisms with oxidation-reduction potential monitoring. Journal of Industrial Microbiology and Biotechnology, Hampshire, v.25, n.25, p. 229-34.

CHO, B.C.; CHANG, C.N.; LIEW, S.L.; HUANG, P.T. (2001). The feasible sequential control strategy of treatment high strength organic nitrogen wastewater with sequencing batch biofilm reactor. Water Science Technology, Oxford, v.43, n.3, p.115-22. 
CHOI, E.; YAN, Z.; CHUNG, T. (2004). Strong nitrogenous and agro-wastewater: current technological overview and future direction. Water Science Technology, Oxford, v.49, n.5-6, p.1-5.

CHUNG, J.; BAE. W. (2002). Nitritie reduction by a mixed culture under conditions relevant to shortcut biological nitrogen removal. Biodegradation, Dordrecht, v.13, p.163-70.

COLETTI, F.J. (1997). Pós-tratamento por lodos ativados de efluente de um reator anaeróbio compartimentado no tratamento de esgoto sanitário. $2 \mathrm{v}$. Dissertação (Mestrado) - Escola de Engenharia de São Carlos, Universidade de São Paulo, São Carlos. 1997.

CORRÊIA, C.L., PEDROSO, R.C. (1997). Headspace gas cromatography with capillary column for urine alcohol determintion. Journal of Chromatography B: Biomedical Sciences and Applications, Amsterdam, v.704, n.1-2, p. 365-8.

DIAB. S.; SHILO, M. (1988). Effect of adhesion to particles on the survival and activity of Nitrosomonas sp. and Nitrobacter sp. Archives of Microbiology, v. 150, p.387-93.

EPA. Environmental Protection Agency. (1999). Wastewater treatment fact sheet. Sequencing batch reactors, Washington.

ETCHEBEHERE, C.; ERRAZQUIN, M.I.; CABEZAS, A.; PIANZOLLA, M.J.; MALLO, M.; LOMBARDI, P., OTTONELLO, G.; BORZACONNI, L.; MUXI, L. (2002). Sludge bed development in denitrifying reactores using different inoculaperformance and microbiological aspects. Water Science Technology, Oxford, v.45, n. 10,p.365-70.

FERNANDEZ-POLANCO, F.; VILLAVERDE, S.; GARCIA, P.A. (1996). Nitrite accumulation in submerged biofilters - combined effects. Water Science Technology, Oxford, v.34, n.3-4, p.371-8.

FORD, D. L.; CHURCHWELL, J. (1980). Comprehensive analisys of nitrification of chemical processing wastewater. Journal Water Pollution Control Federation, Alexandria, v.52, n.11, p.2726-46.

FUX, C.; LANGE, K.; FAESSIER, A.; HUBER, P.; GRUENIGER, B.; SIEGRIST, H. (2003). Nitrogen removal form digester supernatant via nitrite - SBR or SHARON? Water Science Technology, Oxford, v.48, n.8, p.9-18. 
GARRIDO, J.M.; VAN BENTHUM, W.A.J.; VAN LOOSDRECHT, M.C.M.; HEIJNEN, J.J. (1997). Influence of dissolved oxygen concentration on nitrite accumulation in a biofilm airlift suspension reactor. Biotechnology Bioengineering, New York, v.53, p.168-78.

GEE, C.S.; KIM, J.S. (2004). Nitrite accumulation followed by denitrification using sequencing batch reactor. Water Science Technology, Oxford, v.49, n.5-6, p.47-.

GIL, K.I.; CHOI, E. (2004). Nitrogen removal by recycle water nitritation as an attractive alternative for retrofit technologies in municipal wastewater treatment plants. Water Science Technology, Oxford, v.49, n.5-6, p.39-46.

GRIFFITHS, R.I.; WHITELEY, A.S.; O’DONNELL, A.G.; BAILEY, M.J. (2000). Rapid method for coertion of DNA and RNA from natural environments for analysis of ribosomal DNA and rRNA-based microbial community composition. Applied and Environmental Microbiology, Washington, v.66, p.5488-91.

HANAKI, K.; WANTAWIN, C.; OHGAKI, S. (1990). Nitrification at low levels of dissolved oxygen with and without organic loading in a suspended-growth reactor. Water Research, New York, v.24, n.3, p.297-302.

HAO, O.J.; HUANG. J. (1996). Alternating aerobic-anoxic process for nitrogen removal: process evaluation. Water Environment Research, Alexandria, v.68, n.1, p.8393.

HAO, O.J; CHEN, J.M. (1994). Factors affecting nitrite build up in submerged filter system. Journal of Enviromental Engineering, New York, v.120, n.5, p.1298-307.

HENZE, M.; HARREMOES, P.; JANSEN, J.C.; ARVIN, E. (1997). Wastewater Treatment. Biological and Chemical Processes. $2^{\text {nd }}$. ed. German: Springer.

HISCOCK, K.M.; LLOYD, J.W.; LERNER, D.N. (1991). Review of artificial denitrification of groundwater. Water Research, New York, v.25, n.9, p.1099-111.

HOLMAN, J.B.; WAREHAM, D.G. (2003). Oxidation-reduction potencial as a monitoring tool in a low dissolved oxygen wastewater treatment process. Journal of Environmental Engineering, New York, v.129, n.1, p.52-8. 
HOLMAN, J.B.; WAREHAM, D.G. (2005). COD, ammonia, and dissolved oxigyen time profiles in the simultaneous nitrification/denitrification process. Biochemical Engineering Journal, Amsterdam, v.22, p.125-33.

HOOPER, A.B. (1984) Biochemistry of the nitrifying litoautotrophic bacteria. In: SCHLEGEL, H.G.; BOWIEN, B.(ed). Autotrophic bacteria. Madison: Science Technology. Cap.13, p.239-65.

HWANG, B.H.; HWANG, K.Y.; CHOI, E.S.; CHOI, D.K.; JUNG, J.Y. (2000). Enhanced nitrite build-up in proportion to increasing alkalinity $/ \mathrm{NH}^{+}{ }_{4}$ ratio of influent in biofilm reactor. Biotechnology Letters, Dordrecht, v.22, p.1287-90.

IRVINE, R.L.; MILLER, G.; BHAMRAH, A.S. (1979). Sequencing batch treatment of wastewater in rural areas. Journal Water Pollution Control Federation, Alexandria, v.51, n.2, p.244-54.

JENKINS, D.; RICHARD, M.G.; DAIGGER, G.T. (2003). Manual on the causes and control of activated sludge bulking, foaming, and other solids separation problems. $3^{\text {rd }}$ ed. Boca Raton: Lewis Publishers.

JETTEN, M.S.M.; STROUS, M.; VAN PAS-SCHOONEN, K.T.; SCHALK, J.; VAN DONGEN, G.J.M.; VAN DE GRAAF, A.A.; LOGEMANN, S.; MUYZER,G. VAN LOOSDRECHT, M.C.M.; KUENEN, J.G. (1999). The anaerobic oxidation of ammonium. FEMS Microbiology Reviews, Amsterdam, v.22, p.421-37.

KATSOGIANNIS, A.N.; KORNAROS, M.; LYBERATOS, G. (2003). Enhanced nitrogen removal in SBRS bypassing nitrate generation accomplished by multiple aerobic/ anoxic phase pairs. Water Science Technology, Oxford, v.47, n.11, p.53-9.

KIM, D.J.; CHANG, J.S.; LEE, D.I.; HAN, D.W.; YOO, I.K.; CHA, G.C. (2003). Nitrification of high strength ammonia wastewater and nitrite accumulation characteristics. Water Science Technology, Oxford, v.47, n.11, p.45-51.

KIM, Y.S.; NAKANO, K.; LEEL,T.J. KANCHANATAWEE, S.; MATSUMURA, M. (2002). On site nitrate removal of groundwater by an immobilized psycrophilic denitrifier using soluble starch as a carbon source, Journal of Bioscience and Bioengineering, v.93, n.3.p.303-8.

KUAI, L.; VERSTRAETE, W. (1998). Ammonium removal by the oxygen-limited autotrophic nitrification-denitrification system. Applied Environmental Microbiology, Washington, v. 64, p.4500-6. 
LI, B.; BISHOP, P. (2002). ORPP regulation of nutrient removal in activated sludge wastewater treatment plants. Water Science Technology, Oxford, v.46, n.1-2, p.36-9.

LOPES, D.D. (2000) Tratamento de esgoto sanitário empregando reatores compartimentados anaeróbio/aeróbio em série. 272p. Tese (Doutorado) - Escola de Engenharia de São Carlos, Universidade de São Paulo, São Carlos. 2000.

MADIGAN, M.T.; MARTINKO, J.M.; PARKER, J. (1996). BROCK: Biology of microorganisms. 8th ed. Upper Saddle River,USA: Prentice Hall.

MARCHETTO, M. (2001). Remoção de nutrientes do efluente de reator anaeróbio utilizando reatores microaeróbio e com aeração intermitente seguidos de flotação por ar dissolvido. 228p. Tese (Doutorado) - Escola de Engenharia de São Carlos, Universidade de São Paulo, São Carlos. 2001.

MARCHETTO, M.; GIANOTTI, E.P.; CAMPOS, J.R.; PIRES, R.C.; MORAES, E.M. (2003). Estimate of denitrifying microbiota in tertiary sewage treatment and the kinetics of denitrification process using different sources of carbon. Brazilian Journal of Microbiology, v.34, p.104-110.

MATEJU, V.; CIZINSKA, S.; KREJCI, J.; JANOCH, T. (1992). Biological water denitrification - A review. Enzyme Microbiology Technology, New York, v.14, p. 17083.

MENDONÇA, L.C. (2002). Microbiologia e cinética de sistemas de lodos ativados como pós-tratamento de efluente de reator anaeróbio de leito expandido. 184P. Tese (Doutorado) - Escola de Engenharia de São Carlos, Universidade de São Paulo, São Carlos. 2002.

MERZOUKI, M.; DELGENES, J.P.; BERNET, N.; MOLETTA, R.; BENLEMLIH, M. (1998). Polyphosphate-accumulating and denitrifying bacteria isolated from anaerobicanoxic and anaerobic-aerobic sequencing batch reactors. Current Microbiology, New York, v.38, p.9-17.

METCALF e EDDY INC. (1991). Wastewater engineering: Treatment, disposal and reuse. $3^{\text {rd }}$ ed . New York: McGraw Hill International Editions.

MOHSENI BANDPI, A.; ELLIOT, D.J. (1998). Groundwater denitrification with alternative carbon sources. Water Science Technology, Oxford, v.38, n.6, p.237-43. 
MORAES, E.M.; ADORNO, M.A.T.; ZAIAT, M.; FORESTI, E. (2000). Determinação de ácidos voláteis por cromatografia gasosa em efluentes de reatores anaeróbios tratando resíduos líquidos líquidos e sólidos. In: OFICINA E SEMINÁRIO LATINOAMERICANO DE DIGESTÃO ANAERÓBIA, 6., 2000, Recife PE. Anais...Recife: Editora Universitaria - UFPe, p. 2813-2823.

MOURA, R.A. (1997). Técnicas de Laboratório. 3a. edição. São Paulo: Atheneu.

MUNCH, E.; LANT, P.; KELLER, J. (1996). Simultaneous nitrification and denitrification in bench scale sequencing batch reactors. Water Research, New York, v.30, n.2, p.277-84.

NARCIS, N.; REBHUYN, M.; SCHEINDORF, C. (1979). Denitrification at various carbon to nitrogen ratio. Water Research, New York, v.13, p.93-8.

OLIVEIRA, A.L. (2001). Influência do tipo matéria orgânica no processo de desnitrificação em reatores seqüenciais em batelada. 130p. Dissertação (Mestrado) Escola de Engenharia de São Carlos, Universidade de São Paulo, São Carlos. 2001.

OSADA, T.; HAGA, K.; HARADA, Y. (1991). Removal of nitrogen and phosphorus from swine wastewater by the activated sludge units with the intermittent aeration process. Water Research, New York, v.25, n.11, p.1377-88.

PAMBRUM, V.; PAUL, E.; SPÉRANDIO, M. (2004). Treatment of nitrogen and phosphorus in highly concentrated effluent in SBR and SBBR processes. Water Science Technology, Oxford, v.50, n..6, p.269-76.

PEDDIE, C.C.; MAVINIC, D.S.; JENKINS, C.J. (1990). Use of ORP for monitoring and control of aerobic sludge digestion. Journal of Environmental Engineering, New York, v.116, n.3, p.461-71.

POCHANA, K.; KELLER, J. (1999). Study of factors affecting simultaneous nitrification and denitrification (SND). Water Science Technology, Oxford, v.39, n.6, p.61-8.

POO, K.M.; JUNG, B.H.; LEE, S.H.; IM, J.H.; WOO, H.J.; KIM, C.W. (2004). Treatment of strong nitrogen swine wastewater in a full-scale sequencing batch reactor. Water Science Technology, Oxford, v.49, n.5-6, p.315-23. 
PRINCIC, A.; MAHNE, I.; MEG, F.; PAUL, E.A.; TIEDJE, J.M. (1998). Effects of pH and oxygen and ammonium concentration on the community structure of nitrifying bacteria form wastewater. Applied and Environmental Microbiology, v.64, n.10, p.358490 , out.

RA, C.S.; LO, K.V.; SHIN, J.S.; OH, J.S.; HONG, B.J. (2000). Biological nutrient removal with an internal organic carbon source in piggery wastewater treatment. Water Research, New York, v.34, n.3, p.965-73.

RIPLEY, L.E.; BOYLE, W.C.; CONVERSE, J.C. (1986). Improvement alkalimetric monitoring for anaerobic digestion of high-strength wastes. Journal Water Pollution Control Federation, Alexandria, v.58, p.406-411

RUIZ, G.; JEISON, D.; CHAMY, R. (2003). Nitrification with high nitrite accumulation for the treatment of wastewater with high ammonia concentration. Water Research, New York, v.37, p.1371-77.

SASAKI, K.; YAMAMOTO, Y.; TSUMURA, K.; HATSUMATA, S.; TATEWAKI, M. (1993). Simultaneous removal of nitrogen and phosphorus in intermittently aerated 2-tank activated sludge process using DO and ORP bending point control. Water Science Technology, Oxford, v.28, n.11-12, p.513-21.

SCHMIDT, I.; SLIEKERS, O.; SCHMID, M.; BOCK, E.; FUERST, J.; KUENEN, J.G.L.; JETTEN, M.S.M.; STROUS, M. (2003). New concepts of microbial treatment processes for the nitrogen removal in wastewater. FEMS Microbiology Reviews, Amsterdam, v.27, p,481-92.

SCHMIDT, E.L.; BELSER, L. (1982). Nitrifying bacteria. In: PAGE, A.L.; MILLER, R.H.; KEENEY, D.R. Methods of soil analysis. Winsconsin: American Society of Agronomy. Cap. 48, p.1027-42.

SEDLAK, R. (1991). Phosphorus and nitrogen from municipal wastewater: principles and practice. Chelsea: Lewis Publisher.

SIEGRIST, H.; REITHAAR,S.; LAIS, P. (1998). Nitrogen loss in a nitrifying rotating contactor treating ammonium rich leachate without organic carbon. Water Science Technology, Oxford, v.37, n.4-5, p.589-91.

SITÔNIO, C.P. (2001). Pós-tratamento de efluentes de reatores anaeróbios utilizando biofiltro aerado submerso. 80p. Dissertação (Mestrado) - Escola de Engenharia de São Carlos, Universidade de São Paulo, São Carlos. 2001. 
SLIEKERS, A.O.; DERWORT, N.; GOMEZ, J.L.; STROUS, M.; KUENEN, J.G.; JETTEN, M.S.M. (2002). Completely autotrophic nitrogen removal over nitrite in one single reactor. Water Research, New York, v.36, p.2475-82.

SO, C.; YOUNG, L.Y. (1999). Isolation and characterization of a sulfate-reducing bacterium that anaerobically degrades alkanes. Applied and Environmental Microbiology, Washington, v.65, p. 2969-276.

SOUSA, J.T. (1996). Pós tratamento de reator anaeróbio de fluxo ascendente em reator aeróbio seqüencial em batelada e coluna de lodo anaeróbio para desnitrificação. 258p. Tese (Doutorado) - Escola de Engenharia de São Carlos, Universidade de São Paulo, São Carlos. 1996

SOUSA, J.T. de, FORESTI, E. (1996). Domestic sewage treatment in an upflow anaerobic sludge blanket -sequencing batch reactor system. Water Science Technology, Oxford, v.33, n.3, p.73-84.

SPAGNI, A.; BUDAY, J.; RATINI, P.; BORTONE, G. (2001). Experimental considerations on monitoring ORP, $\mathrm{pH}$, conductivitiy and dissolved oxygen in nitrogen and phosphorus biological removal processes. Water Science Technology, Oxford, v.43, n.11, p.197-204.

STÜVEN, R.; VOLLMER, M.; BOCK, E. (1992). The impact of organic matter on nitric oxide formation by Nitrosomonas europea. Archives Microbiology, Berlin, v.158, p.439-43.

STROUS, M.;VAN GERVEN, E.; ZHENG, P.; KUENEN, J.G.; JETTEN, M.S.M. (1997). Ammonium removal from concentrated waste streams with the anaerobic ammonium oxidation (ANAMMOX) process in different reactor configurations. Water Research, New York, v. 31, n.8, p.1955-62.

SURAMPALLI, R.Y.; TIYAGI, R.D.; SCHEIBLE, O.K.; HEIDMAN, J.A. (1997). Nitrification, denitrification and phosphorus removal in sequential batch reactors. Bioresource Technology, v.61, p.151-7.

SURMACZ-GÓRSKA, J.; CICHON, A.J.; MIKSH, K. (1997). Nitrogen removal from wastewater with high ammonia nitrogen concentration via shorter nitrification and denitrification. Water Science Technology, Oxford, v.36, p.73-8. 
SUZUKI, I.; DULAR, U.; KWOK, S.C. (1974). Ammonia or ammonium ion as substrate fo oxidation by Nitrosomonas europaea cells and extracts. Journal of Bacteriology, v. 120, n.1, p.556-8, oct.

TAM, N.F.Y.; LAU, P.S.; WONG, Y.S. (1994). Wastewater inorganic N and P removal by immobilized Chlorella vulgaris. Water Science Technology, Oxford, v.30, n.6, p.369-74.

TANNER, R.S. (1997). Cultivation of bacteria and fungi. In: HURST,C.J. et al. Manual of Environmental Microbiology. Washington.

TIEDJE, J.M. (1982). Denitrification. In: PAGE, A.L.; MILLER, R.H.; KEENEY, D.R. Methods of soil analysis. Winsconsin: American Society of Agronomy. Cap.47, p.101126.

TILCHE, A.; BACIELERI, E.; BORTONE, G.; MALASPINA, F.; PICCININI, S.; STANTE, L. (1999). Biological phosphorus and nitrogen removal in a full scale sequencing batch reator treating piggery wastewater. Water Science Technology, Oxford, v.40, n.1, p.199-206.

TORRES-LOZADA, P. (2000). Tratamento de esgoto sanitário em sistema combinado anaeróbio-aeróbio (UASB/RBS). 99p. Tese (Doutorado) - Escola de Engenharia de São Carlos, Universidade de São Paulo, São Carlos. 2000.

TURK, O.; MAVINIC, D.S. (1987). Benefits of using selective inhibition to remove nitrogen from highly nitrogenous wastes. Environmental Technology Letters, v.8, p.419-26.

TURK, O.; MAVINIC, D.S. (1989). Maintaining nitrite build-up in a system acclimated to free ammonia. Water Research, New York, v.23, n11, p. 1383-88.

VAN DE GRAAF, A.A.; DE BRUIJN, P.; ROBERTSON, L.A.; JETTEN, M.S.M.; KUENEN, J.G. (1997). Metabolic pathway of anaerobic ammonium oxidation on the basis of N-15 studies in a fluidized bed reactor. Microbiology, New York, v.143, p.2415-21.

VAN LOOSDRECHT, M.C.M.; JETTEN, M.S.M. (1998). Microbiological conversions in nitrogen removal. Water Science Technology, Oxford, v.38, n.1, p.1-7.

VERSTRAETE, W.; PHILIPS, S. (1998). Nitrification-denitrification processes and 
technologies in new contexts. Environmental Pollution, Barking, v.102, p.717-26.

VIEIRA, L.G.T. (2000) Desenvolvimento de sistema misto (aeróbio/anaeróbio) de leito fixo para remoção de nitrogênio de esgoto sanitário pré-tratado em reator anaeróbio. 144p. Tese (Doutorado) - Ecola de Engenharia de São Carlos, Universidade de São Paulo, São Carlos. 2000.

VILLAVERDE, S.; GARCIA ENCINA, P.A.; LACALLE, M.L.; FERNANDEZPOLANCO, F. (2000). New operational strategy for SBR technology for total nitrogen removal from industrial wastewaters highly loaded with nitrogen. Water Science Technology, Oxford, v.41, n.12, p.85-93.

VON SPERLING, M.V.; VAN HAANDEL, A.C.; JORDÃO, E.P.; CAMPOS, J.R.; CYBIS, L.F.; AISSE, M.M.; ALÉM SOBRINHO, P. (2001) Pós-tratamento de efluente de reatores anaeróbios por sistema de lodos ativados. In: CHERNICHARO,C.A.L. Póstratamento de efluentes de reatores anaeróbios. Belo Horizonte, MG. Cap. 5, p.279331.

WANG, S.Y.; GAO, D.W.; PENG, Y.Z.; WANG, P.; YANG, Q. (2004). Nitrificationdenitrification via nitrite for nitrogen removal from high nitrogen soybean wastewater with on-line fuzzy control. Water Science Technology, Oxford, v.49, n.5-6, p.121-7.

WAREHAM, D.G.; HALL, K.J.; MAVINIC, D.S. (1993) Real time control of aerobicanoxic sludge digestion using potencial redox. Journal of Environmental Engineering, New York, v.119, n.1, p.120-36.

WETT, B.; RAUCH, W. (2003). The role of inorganic carbon limitation in biological nitrogen removal of extremely concentrated wastewater. Water Research, New York, v. 37, p. $1100-10$.

WIESMAN, U. (1994). Biological nitrogen removal from wastewater. In: Advances in Biochemical Engineering/ Biotechnology, A. Fiechter(ed). Berlin, NY: Springer-Verlag. V.51, p.113-154.

YANG, L.; ALLEMAN, J.E. (1992). Investigation of batchwise nitrite build-up by an enriched nitrification culture. Water Science Technology, Oxford, v.26, n.5-6, p.9971005 .

YOO, H.; AHN, K.; LEE, H.; LEE, K.; KWAK, Y.; SONG, K. (1999). Nitrogen removal from synthetic wastewater by simultaneous nitrification and denitrification (SND) via nitrite in an intermittently-aerated reactor. Water Research, New York, v.33, 
n.1, p.145-54.

YOSHINARI, T.; KNOWLES, R. (1976). Acetylene inhibition of nitrous oxide reduction by denitrifying bacteria. Biochemical Biophysical Research Communications, v.69, p.705-10.

YUN, H.J.; KIM, D.J. (2003). Nitrite accumulation characteristics of high strength ammonia wastewater in an autotrophic nitrifying biofilm reactor. Journal of Chemical Technology and Biotehcnology, Oxford, v. 78, p.377-83.

ZHAO, H.W.; MAVINIC, D.S.; OLDHAM, W.K.; KOCK, F.A. (1999). Controlling factors ofr simultaneous nitrificationa and denitrification in a two-stage intermittent aeration process treating domestic sewage. Water Research, v.33, n.4, p.961-70.

ZENG, R,H.; LEMAIRE, R.; YUAN, Z., KELLER, J. (2003). Simultaneous nitrification, denitrification, and phosphorus removal in a lab-scale sequencing batch reactor. Biotechnology and Bioengineering, New York, v.84, n.2, p.170-8. 


\section{9 - APÊNDICE}

TABELA A1 - Dados das variações temporais das concentrações das Figuras 5.4, 5.5a, 5.7 a e 5.8 a durante a condição operacional de $125 \mathrm{mg} \mathrm{N} / \mathrm{L}$ e concentração de OD de 2 $\mathrm{mg} \mathrm{O}_{2} / \mathrm{L}$ aos $84 \mathrm{~d}$ de experimento. Concentrações de nitrito: não detectadas (ND); temperatura média de $26^{\circ} \mathrm{C}$.

\begin{tabular}{|c|c|c|c|c|c|}
\hline & tempo & $\begin{array}{c}\mathrm{N}- \\
\text { amoniacal }\end{array}$ & $\mathrm{NH}_{3}$ & $\mathrm{pH}$ & $\mathrm{NO}_{3}$ \\
\hline \multirow[t]{5}{*}{ ciclo 1} & 0 & & & & \\
\hline & 0,2 & 7,9 & 0,5 & 8,0 & 0,0 \\
\hline & 2 & 8,5 & 0,4 & 7,9 & 0,0 \\
\hline & 3 & 2,6 & 0,3 & 8,2 & 6,8 \\
\hline & 4 & 0,0 & 0,0 & 8,2 & 10,7 \\
\hline \multirow[t]{5}{*}{ ciclo 2} & 4,2 & 9,1 & 0,7 & 8,0 & 7,0 \\
\hline & 5 & 9,1 & 0,5 & 7,9 & 1,9 \\
\hline & 6 & 7,8 & 0,4 & 7,9 & 0,0 \\
\hline & 7 & 1,5 & 0,1 & 7,9 & 8,0 \\
\hline & 8 & 0,0 & 0,0 & 8,0 & 10,6 \\
\hline \multirow{5}{*}{ ciclo 3} & 8,2 & 6,2 & 0,4 & 8,0 & 6,8 \\
\hline & 9 & 7,1 & 0,3 & 7,8 & 2,5 \\
\hline & 10 & 8,1 & 0,7 & 8,1 & 0,0 \\
\hline & 11 & 1,1 & 0,1 & 7,9 & 8,1 \\
\hline & 12 & 0,0 & 0,0 & 7,8 & 10,0 \\
\hline \multirow{5}{*}{ ciclo 4} & 12,2 & 9,2 & 0,3 & 7,7 & 6,6 \\
\hline & 13 & 9,7 & 0,4 & 7,7 & 3,5 \\
\hline & 14 & 9,8 & 0,4 & 7,7 & 1,5 \\
\hline & 15 & 1,2 & 0,0 & 7,6 & 9,4 \\
\hline & 16 & 0,7 & 0,0 & 7,7 & 10,0 \\
\hline \multirow[t]{8}{*}{ ciclo 5} & 16,2 & 8,0 & 0,3 & 7,7 & 7,4 \\
\hline & 17 & 9,6 & 0,3 & 7,6 & 4,3 \\
\hline & 18 & 9,4 & 0,3 & 7,6 & 2,3 \\
\hline & 19 & 1,1 & 0,0 & 7,4 & 8,6 \\
\hline & 20 & 0,6 & 0,0 & 7,4 & 10,5 \\
\hline & 22 & 0,9 & 0,0 & 7,4 & 7,1 \\
\hline & 23 & 0,9 & 0,0 & 7,5 & \\
\hline & 24 & 0,8 & 0,0 & 7,3 & 6,7 \\
\hline
\end{tabular}


TABELA A2 - Dados das variações temporais das concentrações das Figuras 5.6, 5.7b e $5.8 b$ durante a condição operacional de $125 \mathrm{mgN} / \mathrm{L}$ e concentração de OD de $1,5 \mathrm{mg}$ $\mathrm{O}_{2} / \mathrm{L}$ aos 156 d de experimento. Concentrações de nitrito: não detectadas (ND); temperatura média de $25^{\circ} \mathrm{C}$.

\begin{tabular}{|c|c|c|c|c|c|}
\hline & tempo & $\begin{array}{c}\mathrm{N}- \\
\text { amoniacal }\end{array}$ & $\mathrm{NH}_{3}$ & $\mathrm{pH}$ & $\mathrm{NO}_{3}$ \\
\hline \multirow[t]{6}{*}{ ciclo 1} & 0 & & & & \\
\hline & 0,2 & 6,5 & 1,2 & 8,5 & 0,0 \\
\hline & 1 & 5,2 & 0,9 & 8,5 & 0,0 \\
\hline & 2 & 5,0 & 1,0 & 8,5 & 0,0 \\
\hline & 3 & 0,0 & 0,0 & 8,6 & 10,5 \\
\hline & 4 & 1,7 & 0,5 & 8,8 & 6,2 \\
\hline \multirow[t]{5}{*}{ ciclo 2} & 4,2 & 3,3 & 0,6 & 8,5 & 6,6 \\
\hline & 5 & 3,7 & 0,9 & 8,6 & 3,1 \\
\hline & 6 & 3,7 & 0,8 & 8,6 & 1,1 \\
\hline & 7 & 0,0 & 0,0 & 8,6 & 10,2 \\
\hline & 8 & 0,0 & 0,0 & 8,6 & 11,6 \\
\hline \multirow[t]{5}{*}{ ciclo 3} & 8,2 & 5,9 & 0,3 & 7,8 & 8,4 \\
\hline & 9 & 4,8 & 0,7 & 8,4 & 5,4 \\
\hline & 10 & 5,0 & 0,4 & 8,1 & 3,0 \\
\hline & 11 & 1,0 & 0,0 & 7,5 & 8,1 \\
\hline & 12 & 0,0 & 0,0 & 8,2 & 9,5 \\
\hline \multirow[t]{5}{*}{ ciclo 4} & 12,2 & 4,0 & 0,3 & 8,1 & 4,7 \\
\hline & 13 & 4,8 & 0,8 & 8,5 & 2,7 \\
\hline & 14 & 1,6 & 0,3 & 8,4 & 2,3 \\
\hline & 15 & 0,0 & 0,0 & 8,6 & 7,2 \\
\hline & 16 & 0,0 & 0,0 & 8,5 & 7,6 \\
\hline \multirow[t]{9}{*}{ ciclo 5} & 16,2 & 4,0 & 0,7 & 8,5 & \\
\hline & 17 & 4,8 & 0,6 & 8,3 & 1,4 \\
\hline & 18 & 4,2 & 0,6 & 8,4 & 0,4 \\
\hline & 19 & 0,0 & 0,0 & 8,7 & 7,1 \\
\hline & 20 & 0,2 & 0,1 & 8,7 & 9,4 \\
\hline & 20,2 & 0,0 & 0,0 & 8,7 & 5,8 \\
\hline & 21 & 0,0 & 0,0 & 8,6 & 2,5 \\
\hline & 22 & 0,6 & 0,1 & 8,5 & 1,7 \\
\hline & 24 & 0,0 & 0,0 & 8,6 & 3,0 \\
\hline
\end{tabular}


TABELA A3 - Dados das variações temporais das concentrações das Figuras 5.5b., $5.7 \mathrm{c}$ e $5.8 \mathrm{c}$ durante a condição operacional de $125 \mathrm{mgN} / \mathrm{L}$ e concentração de OD de 2 $\mathrm{mg}_{2} / \mathrm{L}$ aos $180 \mathrm{~d}$ de experimento. Concentrações de nitrito: não detectadas (ND); temperatura média de $25^{\circ} \mathrm{C}$.

\begin{tabular}{|c|c|c|c|c|c|}
\hline & tempo & $\begin{array}{c}\mathrm{N}- \\
\text { amoniacal }\end{array}$ & $\mathrm{NH}_{3}$ & $\mathrm{pH}$ & $\mathrm{NO}_{3}$ \\
\hline \multirow[t]{6}{*}{ ciclo 1} & 0,0 & & & & \\
\hline & 0,7 & 7,9 & 0,2 & 7,9 & 0,3 \\
\hline & 1,3 & 8,5 & & 7,8 & 0,2 \\
\hline & 2,0 & 2,6 & 0,5 & 8,2 & 1,4 \\
\hline & 3,0 & & 0,0 & 8,2 & 5,8 \\
\hline & 4,0 & 0,0 & 0,0 & 8,4 & 9,1 \\
\hline \multirow[t]{5}{*}{ ciclo 2} & 4,7 & 9,1 & 0,2 & 8,1 & 6,9 \\
\hline & 5,0 & 9,1 & 0,1 & 7,7 & 4,7 \\
\hline & 6,0 & 7,8 & 0,1 & 7,8 & 1,6 \\
\hline & 7,0 & 1,5 & 0,0 & 8,2 & 8,2 \\
\hline & 8,0 & 0,0 & 0,0 & 8,2 & 10,0 \\
\hline \multirow[t]{5}{*}{ ciclo 3} & 8,7 & 6,2 & 0,3 & 8,1 & 7,6 \\
\hline & 9,0 & 7,1 & 0,2 & 8,0 & 5,1 \\
\hline & 10,0 & 8,1 & 0,2 & 8,0 & 3,3 \\
\hline & 11,0 & 1,1 & 0,0 & 8,2 & 8,5 \\
\hline & 12,0 & 0,0 & 0,0 & 8,4 & 10,0 \\
\hline \multirow[t]{5}{*}{ ciclo 4} & 12,7 & 9,2 & 0,2 & 8,1 & 7,2 \\
\hline & 13,0 & 9,7 & 0,3 & 8,3 & 6,2 \\
\hline & 14,0 & 9,8 & 0,1 & 8,0 & 4,6 \\
\hline & 15,0 & 1,2 & 0,0 & 8,1 & 8,8 \\
\hline & 16,0 & 0,7 & 0,0 & 8,2 & 11,1 \\
\hline \multirow[t]{8}{*}{ ciclo 5} & 16,7 & 8,0 & 0,3 & 8,0 & 4,9 \\
\hline & 17,0 & 9,6 & 0,3 & 7,9 & 2,6 \\
\hline & 18,0 & 9,4 & 0,3 & 7,9 & 0,5 \\
\hline & 19,0 & 1,1 & 0,1 & 8,1 & 5,3 \\
\hline & 20,0 & 0,6 & 0,1 & 8,0 & 8,1 \\
\hline & 20,5 & 0,9 & 0,3 & 8,0 & 4,6 \\
\hline & 21,5 & 0,9 & 0,3 & 7,9 & 1,3 \\
\hline & 24,0 & 0,8 & 0,4 & 8,0 & 1,8 \\
\hline
\end{tabular}


TABELA A4 - Dados dos ensaios de ciclo anóxico/aeróbio de 4h durante a condição operacional de $125 \mathrm{mgN} / \mathrm{L}$ e concentrações de OD de $2 \mathrm{mg} \mathrm{O}_{2} / \mathrm{L}$ (Figura 5.14) e de 1,5 $\mathrm{mg} \mathrm{O}_{2} / \mathrm{L}$ (Figura 5.15). Concentrações de nitrito: não detectadas (ND).

\begin{tabular}{|l|c|c|}
\multicolumn{1}{c}{} & \multicolumn{2}{c}{$2 \mathrm{mgO}_{2} / \mathrm{L}$} \\
\cline { 2 - 3 } \multicolumn{1}{c|}{} & tempo & \multicolumn{1}{c|}{$\mathrm{NO}_{3}$} \\
\hline anóxico & 12,00 & 8,87 \\
& 12,22 & 6,20 \\
& 12,50 & 4,55 \\
& 12,75 & 4,14 \\
& 13,00 & \\
& 13,17 & 3,73 \\
& 13,50 & 3,17 \\
& 13,75 & 2,92 \\
& 14,00 & 3,05 \\
& & \\
\hline aeróbio & 14,25 & 6,84 \\
& 14,50 & 8,47 \\
& 14,75 & 8,78 \\
& 15,00 & 9,09 \\
& 15,25 & 8,34 \\
& 15,50 & 7,50 \\
& 15,75 & 9,12 \\
& 16,02 & 7,69 \\
\hline
\end{tabular}

\begin{tabular}{|c|c|}
\hline \multicolumn{3}{|c|}{$1,5 \mathrm{mg} \mathrm{O}_{2} / \mathrm{L}$} \\
\hline tempo & $\mathrm{NO}_{3}$ \\
\hline 12,00 & 9,53 \\
12,20 & 7,40 \\
12,50 & 4,70 \\
12,75 & 3,42 \\
13,00 & 2,65 \\
13,25 & 2,36 \\
13,50 & 1,95 \\
13,75 & 2,05 \\
14,00 & 1,59 \\
14,00 & 2,28 \\
\hline 14,25 & 4,53 \\
14,50 & 6,49 \\
14,75 & 7,00 \\
15,00 & 7,21 \\
15,25 & 7,26 \\
15,50 & 6,93 \\
15,75 & 7,13 \\
16,00 & 7,55 \\
\hline
\end{tabular}


TABELA A5 - Dados das variações temporais das concentrações das Figuras 5.18, $5.21 \mathrm{a}, 5.234 \mathrm{a}$ durante a condição operacional de $250 \mathrm{mgN} / \mathrm{L}$ e concentração de OD de 2 $\mathrm{mg} \mathrm{O}_{2} / \mathrm{L}$ aos 30 dias de experimento. Temperatura média de $25^{\circ} \mathrm{C}$.

\begin{tabular}{|c|c|c|c|c|c|c|}
\hline & tempo & $\begin{array}{c}\mathrm{N}- \\
\text { amoniacal }\end{array}$ & $\mathrm{NH}_{3}$ & $\mathrm{pH}$ & $\mathrm{NO}_{2}$ & $\mathrm{NO}_{3}$ \\
\hline \multirow[t]{6}{*}{ ciclo 1} & 0,0 & 10,5 & 0,4 & 7,7 & 0,0 & 0,1 \\
\hline & 0,7 & 20,9 & 0,6 & 7,6 & 0,0 & 0,1 \\
\hline & 1,3 & 23,8 & 1,4 & 8,0 & 0,0 & 0,1 \\
\hline & 2,0 & 21,3 & 1,5 & 8,0 & 0,0 & 0,2 \\
\hline & 3,0 & 18,9 & 2,5 & 8,3 & 0,0 & 0,8 \\
\hline & 4,0 & 13,8 & 2,3 & 8,4 & 2,0 & 0,5 \\
\hline \multirow[t]{5}{*}{ ciclo 2} & 4,7 & 21,2 & 2,3 & 8,2 & 0,0 & 0,2 \\
\hline & 5,0 & 23,6 & 2,4 & 8,2 & 0,0 & 0,2 \\
\hline & 6,0 & 23,5 & 2,1 & 8,2 & 0,0 & 0,2 \\
\hline & 7,0 & 16,5 & 2,0 & 8,3 & 0,0 & 0,3 \\
\hline & 8,0 & 10,0 & 1,3 & 8,3 & 1,7 & 0,6 \\
\hline \multirow[t]{5}{*}{ ciclo 3} & 8,7 & 14,3 & 1,8 & 8,3 & 0,0 & 0,3 \\
\hline & 9,0 & 20,1 & 2,3 & 8,3 & 0,0 & 0,2 \\
\hline & 10,0 & 17,2 & 1,9 & 8,3 & 0,0 & 0,1 \\
\hline & 11,0 & 13,3 & 1,7 & 8,3 & 3,2 & 0,5 \\
\hline & 12,0 & 3,0 & 0,4 & 8,4 & 4,3 & 5,1 \\
\hline \multirow[t]{5}{*}{ ciclo 4} & 12,7 & 8,4 & 0,7 & 8,1 & 0,0 & 0,0 \\
\hline & 13,0 & 9,0 & 0,0 & 8,0 & 0,0 & 0,0 \\
\hline & 14,0 & & & & 0,0 & 0,0 \\
\hline & 15,0 & 0,6 & 0,0 & 8,0 & 3,1 & 1,3 \\
\hline & 16,0 & 0,0 & 0,0 & 8,1 & 3,7 & 1,7 \\
\hline \multirow[t]{8}{*}{ ciclo 5} & 16,7 & 5,5 & 0,5 & 8,2 & 0,0 & 0,1 \\
\hline & 17,0 & 7,7 & 0,6 & 8,1 & 0,0 & 0,0 \\
\hline & 18,0 & 8,2 & 0,5 & 8,0 & 0,0 & 0,0 \\
\hline & 19,0 & 0,5 & 0,0 & 8,0 & 2,2 & 0,8 \\
\hline & 20,0 & 0,0 & 0,0 & 8,1 & 1,8 & 4,0 \\
\hline & 20,7 & 4,0 & 0,3 & 8,1 & 0,9 & 0,5 \\
\hline & 22,0 & 8,0 & 0,5 & 8,0 & 0,0 & 0,0 \\
\hline & 24,0 & 8,0 & 0,5 & 8,0 & 0,0 & 0,0 \\
\hline
\end{tabular}


TABELA A6 - Dados das variações temporais das concentrações das Figuras 5.19, $5.21 \mathrm{~b}, 5.23 \mathrm{~b}$ durante a condição operacional de $250 \mathrm{mgN} / \mathrm{L}$ e concentração de OD de 2 $\mathrm{mg} \mathrm{O}_{2} / \mathrm{L}$ aos 43 dias de experimento. Temperatura média de $25^{\circ} \mathrm{C}$.

\begin{tabular}{|l|ccccccc|}
\cline { 2 - 7 } \multicolumn{1}{c|}{} & tempo & Namoniacal & $\mathrm{NH}_{3}$ & $\mathrm{pH}$ & $\mathrm{NO}_{2}$ & $\mathrm{NO}_{3}$ \\
\hline ciclo 1 & 0 & & 0,7 & 7,7 & & \\
& 0,7 & 21,3 & 1,0 & 7,8 & 0,0 & 0,2 \\
& 1,0 & 24,9 & 0,7 & 7,7 & 0,0 & 0,2 \\
& 2,0 & 21,2 & 1,4 & 8,0 & 0,0 & 0,2 \\
& 4,0 & 20,3 & 1,5 & 8,0 & 0,2 & 0,7 \\
\hline ciclo 2 & 4,7 & 23,3 & 1,3 & 7,9 & 0,0 & 0,1 \\
& 5,0 & 27,8 & 1,7 & 8,0 & 0,0 & 0,2 \\
& 6,0 & 23,9 & 2,1 & 8,2 & 0,0 & 0,3 \\
& 7,0 & 21,9 & 1,4 & 8,2 & 0,1 & 0,8 \\
& 8,0 & 13,7 & 2,4 & 8,3 & 3,7 & 0,6 \\
\hline ciclo 3 & 8,7 & 20,4 & 1,4 & 8,0 & 0,0 & 0,3 \\
& 9,0 & 22,9 & 1,5 & 8,0 & 0,0 & 0,2 \\
& 10,0 & 21,9 & 1,5 & 8,2 & 0,0 & 0,2 \\
& 11,0 & 16,7 & 1,2 & 8,2 & 1,7 & 0,6 \\
& 12,0 & 13,1 & & & 5,6 & 1,1 \\
\hline ciclo 4 & 12,0 & 5,6 & 0,6 & 8,1 & 3,5 & 0,2 \\
& 12,7 & 7,0 & 0,6 & 7,9 & 0,8 & 0,5 \\
& 13,0 & 11,3 & 0,5 & 7,9 & 0,0 & 0,4 \\
& 14,0 & 10,3 & & & & 0,2 \\
& 15,0 & 3,2 & 0,2 & 8,0 & 4,7 & 0,1 \\
& 16,0 & 0,0 & 0,0 & 8,2 & 8,9 & 0,8 \\
\hline ciclo 5 & 16,7 & 12,2 & 1,1 & 8,2 & 0,1 & 0,7 \\
& 17,0 & 13,7 & 0,9 & 8,0 & 0,0 & 0,2 \\
& 18,0 & 11,7 & 0,7 & 8,0 & 0,0 & 0,2 \\
& 19,0 & 1,6 & 0,1 & 8,1 & 7,8 & 1,0 \\
& 20 & 0,0 & 0,0 & 8,1 & 9,2 & 2,2 \\
\hline \multirow{6}{*yyyyy}{} & 20,7 & 13,2 & 1,0 & 8,1 & 0,0 & 0,7 \\
& 22,0 & 13,2 & 0,9 & 8,0 & 0,0 & 0,2 \\
& 24,0 & 15,0 & 1,0 & 8,0 & 0,0 & 1,1 \\
\hline
\end{tabular}


TABELA A7 - Dados do ensaio de ciclo anóxico/aeróbio de 4h durante a condição operacional de $250 \mathrm{mgN} / \mathrm{L}$ e concentração de OD de $2 \mathrm{mg} \mathrm{O}_{2} / \mathrm{L}$ (Figura 5.27).

\begin{tabular}{|c|ccc|cc|}
\cline { 2 - 6 } \multicolumn{1}{c|}{} & tempo & $\begin{array}{c}\mathrm{N}- \\
\text { amoniacal }\end{array}$ & $\mathrm{pH}$ & $\mathrm{NO}_{2}$ & $\mathrm{NO}_{3}$ \\
\hline anóxico & 12,0 & 5,6 & 7,8 & 3,53 & 0,16 \\
& 12,2 & 0,6 & & 6,52 & 0,28 \\
& 12,5 & - & & & \\
& 12,8 & 7,0 & 8,1 & 0,78 & 0,52 \\
& 13,0 & 11,3 & 7,9 & 0,00 & 0,36 \\
& 13,2 & 11,9 & 7,9 & 0,00 & 0,25 \\
& 13,5 & 10,6 & 7,9 & 0,00 & 0,25 \\
& 13,8 & 9,8 & 7,9 & 0,00 & 0,24 \\
& 14,0 & 10,3 & 7,9 & 0,00 & 0,23 \\
\hline \multirow{5}{*}{ aeróbio } & 14,3 & 8,9 & 8,1 & 0,00 & 0,58 \\
& 14,5 & 6,0 & 8 & 2,03 & 0,21 \\
& 14,8 & 3,2 & 8 & 4,67 & 0,14 \\
& 15,0 & - & - & - & - \\
& 15,3 & 0,0 & 7,99 & 8,58 & 1,82 \\
& 15,5 & 0,0 & 8,01 & 9,65 & 1,84 \\
& 15,8 & 0,0 & 8,09 & 8,77 & 1,53 \\
& 16,0 & 0,0 & 8,1 & 8,85 & 0,78 \\
\hline
\end{tabular}

TABELA A8 - Dados das variações temporais das concentrações das Figuras 5.33a e $5.35 \mathrm{a}$, durante a condição operacional de $500 \mathrm{mg} \mathrm{N} / \mathrm{L}$ e concentração de OD de 2,8 mg $\mathrm{O}_{2} /$ L. Temperatura média de $26^{\circ} \mathrm{C}$.

\begin{tabular}{|l|c|c|c|c|c|c|}
\multicolumn{1}{c|}{} & tempo & $\begin{array}{c}\mathrm{N}- \\
\text { amoniacal }\end{array}$ & $\mathrm{NH}_{3}$ & $\mathrm{pH}$ & $\mathrm{NO}_{2}$ & $\mathrm{NO}_{3}$ \\
\hline ciclo 1 & 0,00 & 8,6 & 1,9 & 8,6 & 19,5 & 0,9 \\
& 0,67 & 56,0 & 13,0 & 8,6 & 44,8 & 0,0 \\
& 1,33 & 75,1 & 6,9 & 8,1 & 0,0 & 0,0 \\
& 2,00 & 49,8 & 3,8 & 8,0 & 0,0 & 0,0 \\
& 4,00 & 57,7 & 5,2 & 8,1 & 18,9 & 2,5 \\
& 6,00 & 17,2 & 1,6 & 8,1 & 54,4 & 8,9 \\
& 8,00 & 2,6 & 0,3 & 8,3 & 71,3 & 5,7 \\
& 10,00 & 0,5 & 0,0 & 8,2 & 66,0 & 14,5 \\
& 11,00 & 0,0 & 0,0 & 8,5 & 72,2 & 12,9 \\
\hline & 11,50 & 11,5 & 2,5 & 8,6 & 64,6 & 10,8 \\
& 12,00 & 66,0 & 10,4 & 8,4 & 32,1 & 2,9 \\
& 13,00 & 71,4 & 8,5 & 8,3 & 0,0 & 0,0 \\
& 15,00 & 43,1 & 4,7 & 8,2 & 31,5 & 2,7 \\
& 17,00 & 8,5 & 0,9 & 8,2 & 74,7 & 6,4 \\
& 19,00 & 1,6 & 0,3 & 8,4 & 76,7 & 7,8 \\
& 22,00 & 0,0 & 0,0 & 8,4 & 77,8 & 10,9 \\
\hline & 24,00 & 0,0 & 0,0 & 8,4 & 78,7 & 18,2 \\
\hline
\end{tabular}


TABELA A9 - Dados das variações temporais das concentrações das Figuras 5.33b e $5.35 \mathrm{~b}$ durante a condição operacional de $500 \mathrm{mg} \mathrm{N} / \mathrm{L}$ e concentração de OD de $2,8 \mathrm{mg}$ $\mathrm{O}_{2} / \mathrm{L}$ aos 43 dias de experimento. Temperatura média de $26^{\circ} \mathrm{C}$.

\begin{tabular}{|l|c|c|c|c|c|c|}
\cline { 2 - 7 } \multicolumn{1}{c|}{} & tempo & $\begin{array}{c}\mathrm{N}- \\
\text { amoniacal }\end{array}$ & $\mathrm{NH}_{3}$ & $\mathrm{pH}$ & $\mathrm{NO}_{2}$ & $\mathrm{NO}_{3}$ \\
\hline ciclo 1 & 0,0 & 14,9 & 4,1 & 8,7 & 14,3 & 0,0 \\
& 0,7 & 72,9 & 14,8 & 8,5 & 7,0 & 0,0 \\
& 1,3 & 83,3 & 13,5 & 8,4 & 0,1 & 0,0 \\
& 2,0 & 85,4 & 12,7 & 8,3 & 0,1 & 0,0 \\
& 4,0 & 57,0 & 8,9 & 8,4 & 12,8 & 0,0 \\
& 6,0 & 33,5 & 5,8 & 8,4 & 22,4 & 6,6 \\
& 8,0 & 10,9 & 2,0 & 8,5 & 31,9 & 17,7 \\
& 10,0 & 4,8 & 1,0 & 8,5 & 31,0 & 19,1 \\
& 11,0 & 2,2 & 0,5 & 8,5 & 39,1 & 24,7 \\
\hline ciclo 2 & 11,5 & 2,0 & 0,3 & 8,4 & 39,1 & 21,9 \\
& 12,0 & 61,1 & 8,9 & 8,4 & 23,4 & 0,0 \\
& 13,0 & 78,9 & 10,7 & 8,3 & 0,1 & 0,0 \\
& 15,0 & 51,0 & 5,2 & 8,2 & 19,8 & 3,9 \\
& 17,0 & 16,4 & 2,1 & 8,3 & 38,1 & 18,7 \\
& 19,0 & 4,0 & 0,5 & 8,2 & 42,6 & 24,4 \\
& 22,0 & 2,6 & 0,2 & 8,0 & 43,3 & 31,5 \\
\hline
\end{tabular}

TABELA A10 - Dados do ensaio de ciclo anóxico/aeróbio de $11 \mathrm{~h}$ durante a condição operacional de $500 \mathrm{mgN} / \mathrm{L}$ e concentração de OD de 2,8 $\mathrm{mg} \mathrm{O}_{2} / \mathrm{L}$ (Figura 5.41).

\begin{tabular}{|l|c|c|c|c|c|}
\cline { 2 - 6 } \multicolumn{1}{c|}{} & tempo (h) & $\begin{array}{c}\mathrm{N}- \\
\text { amoniacal }\end{array}$ & $\mathrm{pH}$ & $\mathrm{NO}_{2}$ & $\mathrm{NO}_{3}$ \\
\hline anóxico & 0,0 & 4,1 & - & 37,3 & 7,1 \\
& 0,7 & 85,7 & 9,1 & 0,2 & 6,8 \\
& 1,0 & 89,8 & 8,2 & 0,0 & 0,0 \\
& 1,3 & - & - & 0,0 & 0,0 \\
& 1,5 & - & - & 0,0 & 0,7 \\
& 2,0 & 81,0 & 8,2 & 0,0 & 0,0 \\
\hline \multirow{5}{*}{ aéóbio } & 3,0 & 84,7 & 8,6 & 0,0 & 0,0 \\
& 4,0 & 51,5 & 8,3 & 13,7 & 1,9 \\
& 5,0 & 32,2 & 8,3 & 27,1 & 4,2 \\
& 6,0 & 12,1 & 8,2 & 43,4 & 8,4 \\
& 7,0 & 7,1 & 8,4 & 39,9 & 0,0 \\
& 8,0 & 2,4 & 8,4 & 48,0 & 13,9 \\
& 9,0 & 11,6 & 8,1 & 41,0 & 11,9 \\
& 10,0 & 6,7 & 8,3 & 45,1 & 14,1 \\
& 11,0 & 3,6 & 8,3 & 46,6 & 14,7 \\
& 11,5 & 3,1 & 8,2 & 43,8 & 12,7 \\
\hline
\end{tabular}

TABELA A11 - Dados da variação temporal das concentrações de ácidos voláteis totais 
por cromatografia gasosa. (de acordo com Moraes et al., 2000) durante o período anóxico na condição operacional de $500 \mathrm{mg} \mathrm{N} / \mathrm{L}$ (item 5.1)

\begin{tabular}{|c|l|}
\hline Tempo $(\mathrm{h})$ & Concentração \\
\hline 0 & Zero \\
0,7 & Zero \\
1,0 & Traços de ácido isovalérico $4,2 \times 10^{-2} \mathrm{mg} / \mathrm{L}$ \\
1,25 & Traços de ácido isovalérico $2,3 \times 10^{-2} \mathrm{mg} / \mathrm{L}$ \\
1,5 & $5,5 \mathrm{mg} / \mathrm{L}$ de ácido acético \\
1,75 & $8,8 \mathrm{mg} / \mathrm{L}$ de ácido acético \\
2 & $6,4 \mathrm{mg} / \mathrm{L}$ de ácido acético + Traços de ácido \\
& propiônico \\
\hline
\end{tabular}

Limite de detecção - 3,2 mg/L ácido propiônico e $0,47 \mathrm{mg} / \mathrm{L}$ ácido isovalérico

\section{CÁLCULO DAS VELOCIDADES DE DESNITRIFICAÇÃO DO ITEM 5.1.5}

Feitas as análises no cromátografo de $\mathrm{N}_{2} \mathrm{O}$ para os frascos contendo nitrito e nitrato, as concentrações de $\mathrm{N}_{2} \mathrm{O}$ foram determinadas por meio da integração das áreas dos cromatogramas, correspondentes a $1 \mathrm{ml}$ da fase gasosa injetada, comparadas com a curva de calibração de $\mathrm{N}_{2} \mathrm{O}$.

Dados da curva de calibração de $\mathrm{N}_{2} \mathrm{O}$

\begin{tabular}{|c|c|}
\hline Volume injetado & Área \\
\hline $10 \mu \mathrm{L}$ & 1770 \\
$20 \mu \mathrm{L}$ & 6748 \\
$30 \mu \mathrm{L}$ & 8879 \\
$40 \mu \mathrm{L}$ & 15321 \\
$50 \mu \mathrm{L}$ & 19951 \\
\hline
\end{tabular}

A massa de $\mathrm{N}_{2} \mathrm{O}$ contida em $1 \mathrm{~mL}$ de amostra é dada pela seguinte reta:

onde $\mathrm{y}=$ massa de $\mathrm{N}_{2} \mathrm{O}$

$$
\mathrm{y}=2,61136 \times 10^{-7}+8,1819 \times 10^{-11} \mathrm{x}
$$

$\mathrm{x}=$ área integrada do cromatograma para cada amostra de nitrito ou nittrato

Essas determinações de $\mathrm{N}_{2} \mathrm{O}$ foram convertidas para a concentração total de $\mathrm{N}_{2} \mathrm{O}$ contida nos frascos de reação de acordo com a equação proposta por TIEDJE (1982), levando-se em conta, o coeficiente de absorção de Bunsern:

$$
\mathrm{M}=\operatorname{cg}(\mathrm{Vg}+\mathrm{V} 1 \alpha)
$$

Onde $\mathrm{M}=$ quantidade total de $\mathrm{N}_{2} \mathrm{O}$ na fase líquida e gasosa $(\mathrm{g})$;

$\mathrm{Cg}=$ concentração de $\mathrm{N}_{2} \mathrm{O}(\mathrm{g} / \mathrm{mL})=$ massa $/ \mathrm{vg}=$ massa $/ 1 \mathrm{~mL}$;

$\mathrm{Vg}=$ volume da fase gasosa $(\mathrm{mL})=100 \mathrm{~mL}$;

$\mathrm{Vl}=$ volume da fase líquida $(\mathrm{mL})=300 \mathrm{~mL}$;

$\alpha=$ coeficiente de absorção de Bunsen para o $\mathrm{N}_{2} \mathrm{O}\left(\mathrm{em} 30^{\circ} \mathrm{C}=0,472\right)$

Desse modo, a concentração total de $\mathrm{N}_{2} \mathrm{O}$ é:

$$
\mathrm{M}=\text { massa de } \mathrm{N}_{2} \mathrm{O} \times(100+300 * 0,472)=241,6 \times \text { massa de } \mathrm{N}_{2} \mathrm{O}
$$


As concentrações finais de $\mathrm{N}_{2} \mathrm{O}$ foram expressas em números de moles de acordo com a pureza do gás $\mathrm{Nt}=\mathrm{Mx} 44$ [número de moles de $\mathrm{N}_{2} \mathrm{O}$ ]

Tabela 1 - Resultados de produção de $\mathrm{N}_{2} \mathrm{O}$ para o frasco contendo nitrito

\begin{tabular}{|c|c|c|c|c|c|}
\hline tempo (h) & Área & massa & M nitrito & nt nitrito & $\begin{array}{c}\text { n nitrito } \\
\text { acumulado }\end{array}$ \\
\hline 0 & 0 & 0 & 0 & 0 & 0 \\
0,22 & 3737 & $5,67 \times 10^{-7}$ & 0,006026 & 0,000137 & 0,000137 \\
0,62 & 11637 & $1,21 \times 10^{-6}$ & 0,012897 & 0,000293 & 0,0004301 \\
0,85 & 13829 & $1,39 \times 10^{-6}$ & 0,014804 & 0,000336 & 0,0007665 \\
1,07 & 14501 & $1,45 \times 10^{-6}$ & 0,015388 & 0,000350 & 0,0011163 \\
1,27 & 14637 & $1,46 \times 10^{-6}$ & 0,015507 & 0,000352 & 0,0014687 \\
1,52 & 13630 & $1,38 \times 10^{-6}$ & 0,014631 & 0,000333 & 0,0018012 \\
\hline
\end{tabular}

Tabela 2 - Resultados de produção de $\mathrm{N}_{2} \mathrm{O}$ para o frasco contendo nitrato

\begin{tabular}{|c|c|c|c|c|c|}
\hline tempo $(\mathrm{H})$ & Área & massa & M nitrato & nt nitrato & $\begin{array}{c}\text { n nitrato } \\
\text { acumulado }\end{array}$ \\
\hline 0 & 0 & 0 & 0 & 0 & 0 \\
0,23 & 7027 & $8,36 \times 10^{-7}$ & 0,008888 & 0,000202 & 0,000202 \\
0,62 & 10069 & $1,08 \times 10^{-6}$ & 0,011534 & 0,000262 & 0,0004641 \\
0,85 & 13482 & $1,36 \times 10^{-6}$ & 0,014502 & 0,000333 & 0,0007937 \\
1,03 & 15181 & $1,50 \times 10^{-6}$ & 0,015980 & 0,000363 & 0,0011569 \\
1,25 & 15945 & $1,57 \times 10^{-6}$ & 0,016644 & 0,000378 & 0,0015352 \\
1,5 & 14948 & $1,48 \times 10^{-7}$ & 0,015777 & 0,000359 & 0,0018938 \\
\hline
\end{tabular}

Onde $\mathrm{M}$ é a concentração total de massa de $\mathrm{N}_{2} \mathrm{O}$ nos frascos e nt = número de moles total

Os resultados do número de moles acumulado foram plotados e ajustados de acordo com uma função polinomial e as velocidades máximas da produção de $\mathrm{N}_{2} \mathrm{O}$ foram calculadas por regressão linear dos pontos obtidos na fase exponencial. Com esses valores e a concentração de sólidos supesnsos voláteis (SSV), foram calculadas as velocidades máximas específicas para cada situação em estudo.

Abaixo estão os dados obtidos dos ajustes de curvas polinomiais para nitrito e nitrato.

Regressão polinomial para nitrito e nitrato $\mathrm{Y}=\mathrm{A}+\mathrm{B} 1 \mathrm{X}+\mathrm{B} 2 \mathrm{X}^{2}+\mathrm{B} 3 \mathrm{X}^{3}$

\begin{tabular}{|c|c|c|}
\hline parâmetro & nitrito & nitrato \\
\hline A & $2,46 \times 10^{-7}$ & $1,83 \times 10^{-5}$ \\
B1 & $7,22 \times 10^{-4}$ & $7,3 \times 10^{-4}$ \\
B2 & $-4,53 \times 10^{-4}$ & $-5,34 \times 10^{-4}$ \\
B3 & $8,04 \times 10^{-5}$ & $1,35 \times 10^{-4}$ \\
R $^{2}$ & 0,99991 & 0,96348 \\
\hline
\end{tabular}

